\title{
A Palladium-Catalyzed Aminoalkynylation Strategy towards Bicyclic Heterocycles: Synthesis of Trachelanthamidine. **
}

\author{
Stefano Nicolai, Cyril Piemontesi, and Jérôme Waser*
}

Dedicated to Professor Barry M. Trost on the occasion of his 70th birthday

Nitrogen-containing heterocycles are omnipresent in natural products and biologically active compounds. Among them, pyrrolizidine and indolizidine alkaloids have attracted a broad interest for their potential pharmacological applications. Furthermore, their polycyclic structures, frequently incorporating multiple chiral centers, have been the testing ground for new C-C and $\mathrm{C}-\mathrm{N}$ bond forming methods since several decades. ${ }^{[1]}$

In this context, we envisaged a novel strategy to access both pyrrolizidines and indolizidines involving the initial aminoalkynylation of olefins to afford 5-propargyl lactams (Figure 1). This step allows both $\mathrm{C}-\mathrm{N}$ bond formation and introduction of the two missing carbon atoms in a single transformation. The amination of olefin is still a major challenge in organic synthesis and only recently progress has been realized in intramolecular hydroamination, ${ }^{[2]}$ aza-Wacker reaction ${ }^{[3]}$ and more challenging multiple aminofunctionalization of alkenes. ${ }^{[4]}$ In particular, the simultaneous formation of $\mathrm{C}-\mathrm{N}$ and $\mathrm{C}-\mathrm{C}$ bond has been focused mostly on aminoarylation and aminocarbonylation. In this context, the aminoalkynylation process is still unknown, despite its tremendous potential for further functionalization. We have reported in 2010 the intramolecular oxyalkynylation of alkenes. ${ }^{[5]}$ However, we were unable to use our protocol efficiently in the case of amination. The second required cyclization could be envisaged via hydroamination of the triple bond, ${ }^{[2,6]}$ or a two-steps alternative via vinyl halides. ${ }^{[7]}$ Both approaches are well established for the intermolecular synthesis of enamides, but they have never been reported to access pyrrolizidinones or indolizidinones.

Herein, we report the exceptional efficiency of lithium palladate catalysts for the intramolecular aminoalkynylation of olefins using hypervalent iodine reagents. The reaction is broadly applicable, working not only for $\gamma$ and $\delta$-lactams but also for oxazolidinones, imidazolidinones and indole or pyrrole piperazinones. The importance of the aminoalkynylation reaction is demonstrated in the elaboration of the lactam acetylenes into pyrrolizidines and indolizidines using a two-steps procedure (In-mediated iodination ${ }^{[8]}$ and $\mathrm{Cu}$-catalyzed vinylation), ${ }^{[7 \mathrm{c}-\mathrm{d}]}$ which culminated in the total synthesis of the natural product $( \pm)$-trachelanthamidine.

[*] S. Nicolai, C. Piemontesi and Prof. Dr. J. Waser Laboratory of Catalysis and Organic Synthesis Ecole Polytechnique Fédérale de Lausanne EPFL SB ISIC LCSO, BCH 4306, 1015 Lausanne $(\mathrm{CH})$ Fax: (+)41216939700 E-mail: jerome.waser@epfl.ch Homepage: http://lcso.epfl.ch/

[**] EPFL and SNF (grant number 200021_119810) are acknowledged for financial support.

Supporting information for this article is available on the WWW under http://www.angewandte.org or from the author.

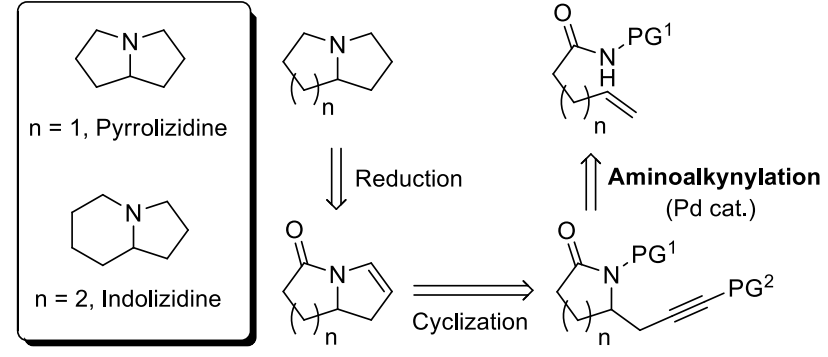

Figure 1. Strategy for the synthesis of pyrrolizidines and indolizidines.

A preliminary screening was performed subjecting protected/activated amides derived from 4-pentenoic acid to the protocol developed for oxyalkynylation (triisopropylsilyl ethynyl benziodoxolone (TIPS-EBX (2a)), 10 mol \% $\quad \operatorname{Pd}($ hfacac)2, dichloromethane). ${ }^{[5,9]} \mathrm{N}$-tosyl amide 1a was the most promising substrate, but the yield was low (33\%), due to decomposition (entry 1, Table 1).

Table 1. Optimization of the Aminoalkynylation Reaction.

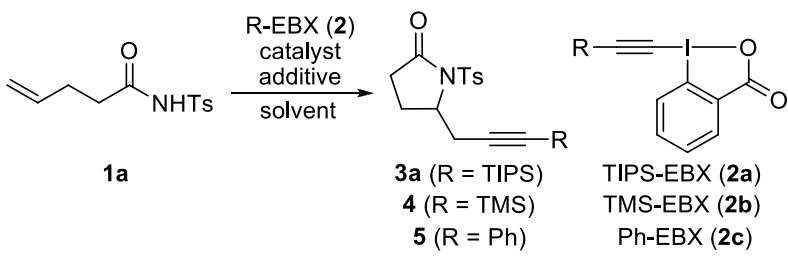

\begin{tabular}{cccccc}
\hline entry & $\mathrm{R}$ & catalyst & additive & solvent & yield ${ }^{[\mathrm{a}]}$ \\
\hline 1 & TIPS & $\mathrm{Pd}\left(\mathrm{hfacac}_{2}\right.$ & - & $\mathrm{CH}_{2} \mathrm{Cl}_{2}$ & $33 \%$ \\
2 & TIPS & $\mathrm{PdCl}_{2}$ & - & $\mathrm{EtOH}$ & $57 \%$ \\
3 & TIPS & $\mathrm{PdCl}_{2}$ & $\mathrm{LiCl}$ & $\mathrm{EtOH}$ & $76 \%(75 \%)^{[\mathrm{b}]}$ \\
4 & TIPS & $\mathrm{PdCl}_{2}$ & $\mathrm{Bu}_{4} \mathrm{NCl}$ & $\mathrm{EtOH}$ & $48 \%$ \\
5 & TIPS & $\mathrm{PdCl}_{2}$ & $\mathrm{LiBF}_{4}$ & $\mathrm{EtOH}$ & $20 \%$ \\
6 & TIPS & $\mathrm{PdCl}_{2}$ & $\mathrm{LiCl}$ & $\mathrm{EtOH}$ & $88 \%{ }^{[c]}$ \\
7 & TIPS & $\mathrm{Li}_{2}\left[\mathrm{PdCl}_{4}\right]$ & - & $\mathrm{EtOH}$ & $84 \%{ }^{[\mathrm{b}]}$ \\
8 & TMS & $\mathrm{PdCl}_{2}$ & $\mathrm{LiCl}$ & $\mathrm{EtOH}$ & $23 \%{ }^{[\mathrm{cc}}$ \\
9 & $\mathrm{Ph}$ & $\mathrm{PdCl}_{2}$ & $\mathrm{LiCl}$ & $\mathrm{EtOH}$ & $58 \%{ }^{[\mathrm{cc}]}$ \\
\hline
\end{tabular}

[a] Reaction conditions: $0.069 \mathrm{mmol}$ 1a, $0.014 \mathrm{mmol}$ catalyst, 0.084 mmol R-EBX (2), $0.084 \mathrm{mmol}$ additive in $1.75 \mathrm{~mL}$ solvent, $15 \mathrm{~h}, \mathrm{RT}$. Yield was determined via ${ }^{1} \mathrm{H}-\mathrm{NMR}$. [b] Isolated yield using $0.40 \mathrm{mmol}$ 1a, $0.040 \mathrm{mmol}$ catalyst, $0.48 \mathrm{mmol}$ R-EBX (2), $0.48 \mathrm{mmol}$ additive in $10 \mathrm{~mL}$ solvent, $3.5 \mathrm{~h}, \mathrm{RT}$. [c] Isolated yield using $1.44 \mathrm{mmol} \mathrm{LiCl}$. 
Optimization of the reaction conditions using the previously discovered catalyst was not successful. ${ }^{[10]}$ An interesting lead result was obtained with $\mathrm{PdCl}_{2}$ in EtOH (entry 2). Better yields were observed with $\mathrm{LiCl}$ as additive (entry 3 ), while other $\mathrm{Li}$ or chloride salts were less efficient (entries 4,5). Three equivalents of $\mathrm{LiCl}$ in comparison to 2a were optimal (entry 6). Under these conditions, the active catalyst could be $\mathrm{Li}_{2}\left[\mathrm{PdCl}_{4}\right]$ formed in situ. Indeed, when $\mathrm{Li}_{2}\left[\mathrm{PdCl}_{4}\right]$ was used as the catalyst with $\mathbf{1 a}, \mathbf{3 a}$ was isolated in the same yield as when using $\mathrm{PdCl}_{2} / \mathrm{LiCl}$ (entry 7). ${ }^{[11]}$ One possible explanation for this effect would be that halide ions can slow down side reactions, in particular $\beta$-hydride elimination. ${ }^{[12]}$ To the best of our knowledge, this is the first example of the use of a palladate complex for the carboamination of olefins. The reaction was performed at room temperature using analytical grade $\mathrm{EtOH}$ under ambient atmosphere. $\mathrm{LiCl}$ is inexpensive, $\mathrm{PdCl}_{2}$ is the most broadly used Pd salt and TIPS-EBX (2a) is commercially available, contributing to make the method highly practical. The use of ethynylbenziodoxolone (EBX) reagents was required, as no product was obtained using alkynyl halides or alkynyliodonium salts. The smaller TMS group gave a lower yield (entry 8), but the introduction of phenyl acetylene was possible in 58\% yield (entry 9). ${ }^{[13]}$

The scope of the reaction was then examined (Table 2). Modification of the benzenesulfonyl group showed that tosyl amide 1a was optimal (entry 1). 4-Methoxybenzenesulfonyl amide $\mathbf{1 b}$ gave a similar yield (entry 2). The lactam was obtained in $50 \%$ yield with the easily removable nosyl group (entry 3). Good results were obtained for the synthesis of $\mathrm{N}$-protected 5-propargyl pyrrolidinones (entries 4-8). The reaction was tolerant to substitution $\alpha$ to the carbonyl (entries 4-6), allowing facile access to azaspiro compounds (entries 5,6). Substitution at the allylic position with a phenyl group gave the trans product in 71\% yield and 90:10 dr (entry 7). The reaction also worked for the synthesis of bicyclic heterocycle $\mathbf{3 h}$ (entry 8 ). Cyclization reactions to give 6-membered rings are usually more challenging. Nevertheless, simple $\mathrm{N}$-tosyl 5hexenamide gave propargyl piperidone 3i in 57\% yield (entry 9). The yield increased for more rigid substrates (entries 10-12). Arylpiperazines derived from pyrroles or indoles are key structural elements in bioactive compounds. ${ }^{[14]} \mathrm{We}$ then examined substitution on the double bond. While no reactivity was observed with vicinally disubstituted olefins, the cyclized product could be isolated in $62 \%$ yield with geminally disubstituted alkene $\mathbf{1 m}$ under modified reaction conditions (entry 13). This result is promising, as it indicates that the reaction could be extended to substituted olefins after adequate optimization.

As our protocol has been successful for the synthesis of lactams, we wondered if a second heteroatom would be tolerated. We concentrated first on $O$-allyl and homoallyl carbamates (Table 3, entries 1-4). Allyl tosylcarbamate (6a) was converted to the corresponding 4-propargyl oxazolidinone 7a in $83 \%$ yield (entry 1 ). Substitution at the allylic position was also tolerated (entries 2, 3), although the diastereoselectivity was lower than for $N$-tosyl pentenamides. Homoallyl tosylcarbamate $6 \mathbf{d}$ afforded the sixmembered ring product in 59\% yield (entry 4). Finally, we studied the behaviour of allyl ureas under the reaction conditions (entries 57). Control of $O$ - versus $N$ - cyclization is more difficult for urea, due to the enhanced nucleophilicity of the oxygen atom. Nevertheless, only propargyl imidazolidinones were isolated in $65-79 \%$ yields using both free or allyl and benzyl protected ureas.

As several new bonds are formed during the reaction, understanding the mechanism is challenging. Complete conversion of the hypervalent iodine reagent into 2-iodobenzoic acid and the dimerized acetylene was observed by ${ }^{1} \mathrm{H}$ NMR when it was mixed with a stoichiometric amount of $\mathrm{Li}_{2}\left[\mathrm{PdCl}_{4}\right]$. A shift of the olefins and aliphatic signals was observed in the ${ }^{1} \mathrm{H}$ NMR spectrum of the $\mathrm{N}$-tosyl amide 1a when added to a stoichiometric amount of the catalyst. ${ }^{[15]}$ The addition of TIPS-EBX (2a) to this mixture then resulted into rapid formation of the product. These preliminary results seemed to indicate that an initial aminopalladation followed by oxidative alkynylation could be envisaged. Further investigation is obviously required to elucidate the mechanism.

Table 2. Aminoalkynylation of Activated Amides.

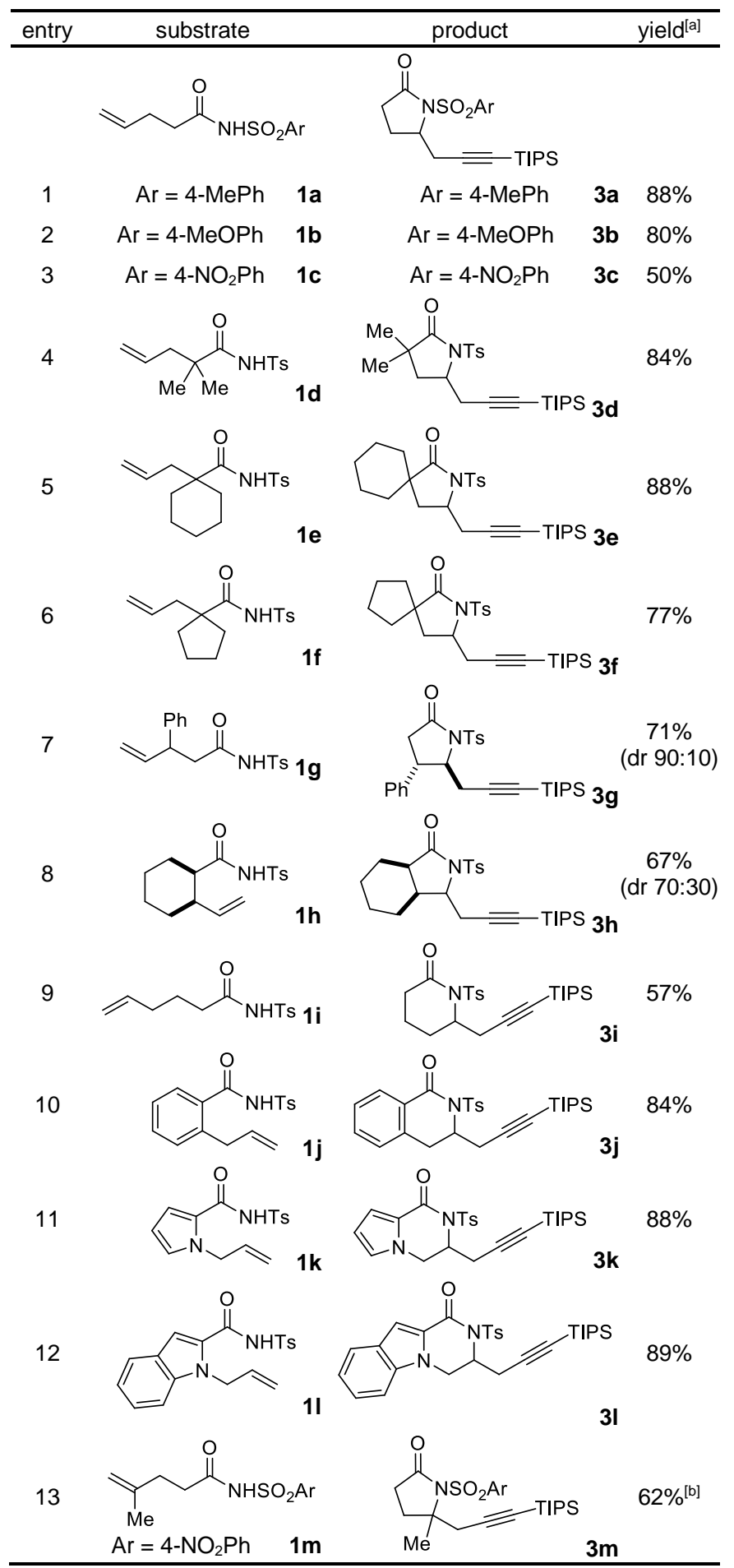

[a] Reaction conditions: $0.40 \mathrm{mmol} 1,0.040 \mathrm{mmol} \mathrm{PdCl}_{2}, 0.48 \mathrm{mmol}$ TIPS-EBX (2a), $1.44 \mathrm{mmol} \mathrm{LiCl}$ in $10 \mathrm{~mL} \mathrm{EtOH,} \mathrm{2-5} \mathrm{h,} \mathrm{RT.} \mathrm{[b]} 0.40$ mmol 1, 0.040 mmol Pd(hfacac) $)_{2}, 0.48$ mmol TIPS-EBX (2a), 0.48 mmol 4-chlorosalicylic acid in $10 \mathrm{~mL} \mathrm{CH}_{2} \mathrm{Cl}_{2}, 15 \mathrm{~h}, \mathrm{RT}$. 
Table 3. Aminoalkynylation of Activated Carbamates and Ureas.

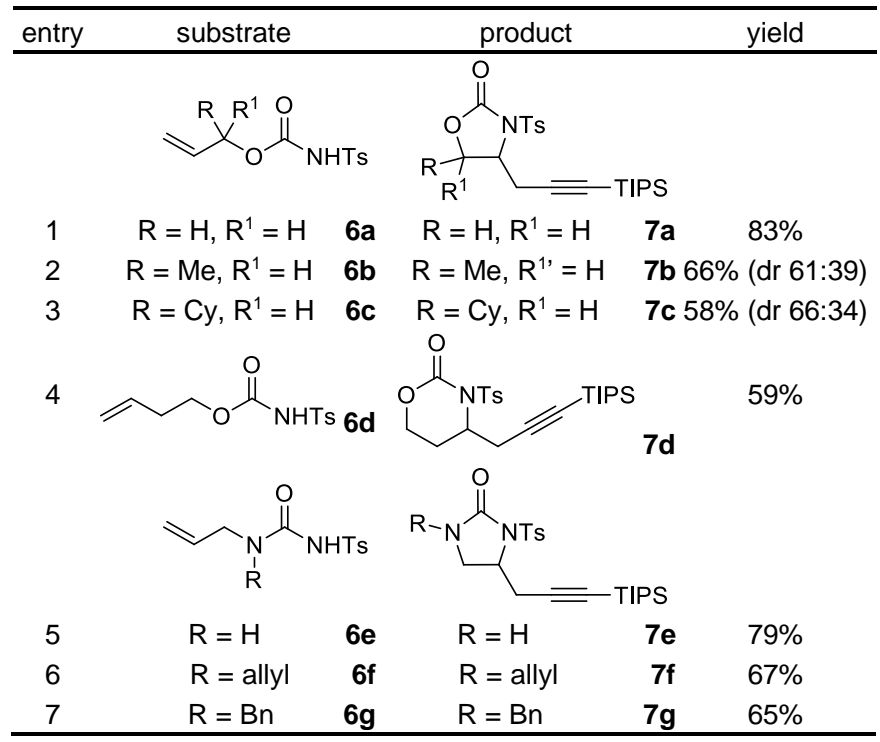

Reaction conditions: $0.40 \mathrm{mmol}$ 6, $0.040 \mathrm{mmol} \mathrm{PdCl}_{2}, 0.48 \mathrm{mmol}$ TIPS-EBX (2a), $1.44 \mathrm{mmol} \mathrm{LiCl} \mathrm{in} 10 \mathrm{~mL} \mathrm{EtOH,} \mathrm{2-5} \mathrm{h,} \mathrm{RT.}$

At this point, we turned our attention to the second cyclization step required to access pyrrolizidine and indolizidine heterocycles. Removal of the tosyl group from 3a could be performed in $97 \%$ yield by treatment with Li-naphthalenide. The desilylation of the triple bond was then accomplished with TBAF in $87 \%$ yield. Cyclization of pyrrolizidinone 8a was then examined (Scheme 1). As no product was obtained using Ru-catalyzed methods reported for the intermolecular hydroamination of alkynes with amides, ${ }^{[6-c]}$ we investigated a two-steps approach via a vinyl iodide intermediate. Hydroindiation of the acetylene with $\mathrm{HInCl}_{2}$ followed by quenching with iodine gave the $Z$-vinyl iodide in $99 \%$ yield $(Z: E=15: 1){ }^{\left[{ }^{[8]}\right.}$ This is the first example of the use of Oshima's method in the presence of an amide group and demonstrates the strength of this underutilized protocol. The conditions described by Buchwald for the intermolecular vinylation of amides gave then pyrrolizidine 9a in $76 \%$ yield. ${ }^{[7 \mathrm{c}-\mathrm{d}]}$ The same procedure could be successfully applied to the cyclization of oxazolidinone $\mathbf{8 b}$ and indolizidinone $\mathbf{8 c}$ in $65 \%$ and $72 \%$ overall yields respectively.

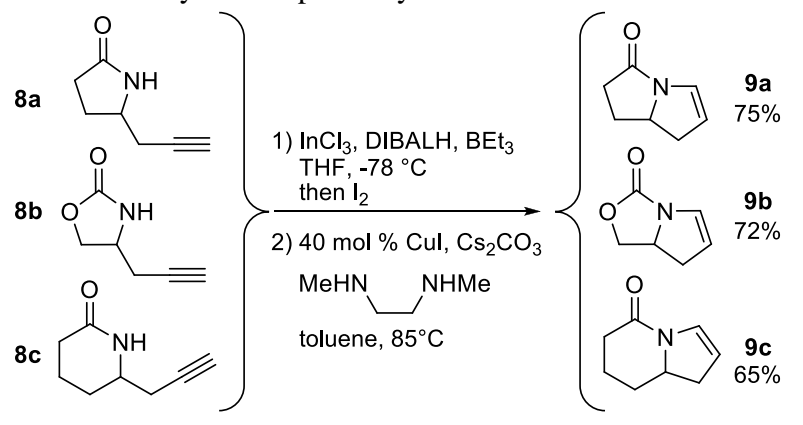

Scheme 1. Cyclization to Form Bicyclic Heterocycles.

Our strategy was then applied to the synthesis of the pyrrolizidine alkaloid ( \pm )-trachelanthamidine (16) (Scheme 2).$^{[16]}$ Amide 11 was obtained via Johnson-Claisen rearrangement of protected butene diol $\mathbf{1 0},,^{[17]}$ followed by hydrolysis and reaction with $p$-tosylisocyanate. The aminoalkynylation of tosyl amide $\mathbf{1 1}$ proceeded in $72 \%$ yield and 83:17 dr. The tosyl and silyl groups were removed and cyclization on the triple bond proceeded in $69 \%$ yield. Separation of the two diastereoisomers could be achieved after cyclization. Reduction of the enamide and debenzylation of the alcohol was achieved in quantitative yield. Finally, reduction of the amide group using $\mathrm{LiAlH}_{4}$ gave racemic trachelanthamidine (16) in 9 steps and $22 \%$ overall yield from $\mathbf{1 0}$.

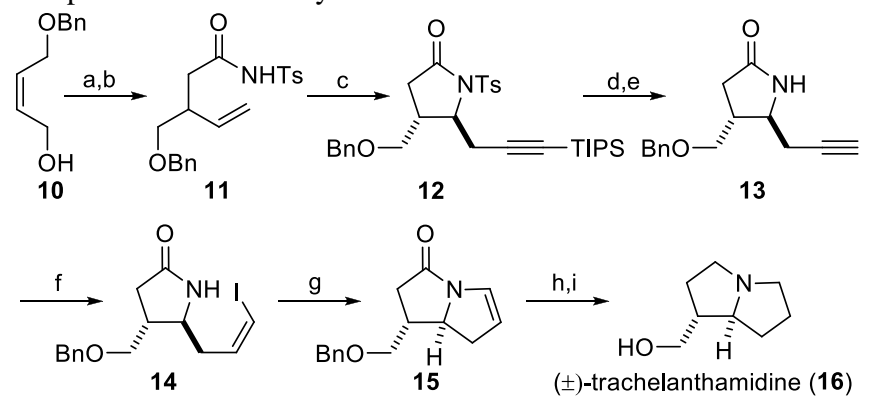

Scheme 2. Total Synthesis of ( \pm -Trachelanthamidine (16). Reaction conditions: a) $\mathrm{CH}_{3} \mathrm{C}(\mathrm{OEt})_{3}, \mathrm{EtCO}_{2} \mathrm{H}, 100^{\circ} \mathrm{C}$ to $160^{\circ} \mathrm{C}$; then $\mathrm{KOH}$, $\mathrm{MeOH}$, reflux, 80\%; b) p-TosylNCO, $\mathrm{Et}_{3} \mathrm{~N}$, THF, RT, $80 \%$; c) $5 \mathrm{~mol} \%$ $\mathrm{PdCl}_{2}, \quad \mathrm{LiCl}$, TIPS-EBX (2a), EtOH, RT, 72\%; 83:17 dr; d) Li/Naphthalene, THF, $-78^{\circ} \mathrm{C}, 77 \%$; e) TBAF, THF, $0^{\circ} \mathrm{C}$ to RT, $98 \%$; f) i. $\mathrm{InCl}_{3}$, DIBALH, ii. Et 3 B, iii. $\mathrm{I}_{2}$, THF, $-50^{\circ} \mathrm{C}, 95 \%$; g) $40 \mathrm{~mol} \% \mathrm{Cul}$, $\mathrm{Cs}_{2} \mathrm{CO}_{3}, \mathrm{~N}^{\prime} \mathrm{N}^{\prime}$-dimethylethylenediamine, toluene, $85^{\circ} \mathrm{C}, 73 \%$; h) $\mathrm{H}_{2}$, $\mathrm{Pd} / \mathrm{C}, \mathrm{MeOH}, \mathrm{RT}$, quantitative; i) $\mathrm{LiAlH}_{4}, \mathrm{THF}$, reflux, $94 \%$.

In summary, a novel strategy for the synthesis of nitrogen bridged bicyclic heterocycles has been reported. The Pd-catalyzed intramolecular aminoalkynylation of terminal olefins was operationally simple and could be successfully applied to tosyl amides, carbamates and ureas. Both five and six membered rings were obtained in good to excellent yields. After facile deprotection, iodination of the triple bond, followed by $\mathrm{Cu}$-catalyzed vinylation of the amide gave access to the core of pyrrolizidine and indolizidine heterocycles and led to a new total synthesis of trachelanthamidine (16). Further work towards the elucidation of the reaction mechanism and the development of an asymmetric version is currently ongoing in our group.

Received: ((will be filled in by the editorial staff))

Published online on ((will be filled in by the editorial staff))

Keywords: Alkynylation - Alkaloids - Amination - Catalysis . Heterocyclic Compd. · Hypervalent lodine.

[1] a) J. R. Liddell, Nat. Prod. Rep. 2002, 19, 773; b) J. P. Michael, Nat. Prod. Rep. 2007, 24, 191.

[2] T. E. Muller, K. C. Hultzsch, M. Yus, F. Foubelo, M. Tada, Chem. Rev. 2008, 108, 3795.

[3] For a few selected references see: a) L. S. Hegedus, G. F. Allen, J. J. Bozell, E. L. Waterman, J. Am. Chem. Soc. 1978, 100, 5800; b) S. R. Fix, J. L. Brice, S. S. Stahl, Angew. Chem. 2002, 114, 172; Angew. Chem., Int. Ed. 2002, 41, 164; c) R. I. McDonald, S. S. Stahl, Angew. Chem. 2010, 122, 5661; Angew. Chem., Int. Ed. 2010, 49, 5529; d) R. M. Trend, Y. K. Ramtohul, B. M. Stoltz, J. Am. Chem. Soc. 2005, 127, 17778 .

[4] Aminocarbonylation: a) Y. Tamaru, M. Hojo, Z. Yoshida, J. Org. Chem. 1988, 53, 5731; b) T. A. Cernak, T. H. Lambert, J. Am. Chem. Soc. 2009, 131, 3124; Aminooxygenation: c) E. J. Alexanian, C. Lee, E. J. Sorensen, J. Am. Chem. Soc. 2005, 127, 7690; d) L. V. Desai, M. S. Sanford, Angew. Chem. 2007, 119, 5839; Angew. Chem., Int. Ed. 2007, 46, 5737; e) P. H. Fuller, J. W. Kim, S. R. Chemler, J. Am. Chem. Soc. 2008, 130, 17638; f) H. M. Lovick, F. E. Michael, J. Am. Chem. Soc. 2010, 132, 1249; g) T. de Haro, C. Nevado, Angew. Chem. 2011, 123, 936; Angew. Chem., Int. Ed. 2011, 50, 906; Diamination: 
h) T. P. Zabawa, D. Kasi, S. R. Chemler, J. Am. Chem. Soc. 2005, 127, 11250; i) J. Streuff, C. H. Hovelmann, M. Nieger, K. Muniz, J. Am. Chem. Soc. 2005, 127, 14586; j) K. Muniz, J. Am. Chem. Soc. 2007, 129, 14542; k) K. Muniz, C. H. Hovelmann, J. Streuff, J. Am. Chem. Soc. 2008, 130, 763; 1) P. A. Sibbald, C. F. Rosewall, R. D. Swartz, F. E. Michael, J. Am. Chem. Soc. 2009, 131, 15945; Arylamination: m) J E. Ney, J. P. Wolfe, Angew. Chem. 2004, 116, 3689; Angew. Chem., Int. Ed. 2004, 43, 3605; n) J. P. Wolfe, Synlett 2008, 2913; o) J. D. Neukom, N. S. Perch, J. P. Wolfe, J. Am. Chem. Soc. 2010, 132, 6276; p) C. F. Rosewall, P. A. Sibbald, D. V. Liskin, F. E. Michael, J. Am. Chem. Soc. 2009, 131, 9488; q) W. E. Brenzovich, D. Benitez, A. D. Lackner, H. P. Shunatona, E. Tkatchouk, W. A. Goddard, F. D. Toste, Angew. Chem. 2010, 122, 5651; Angew. Chem., Int. Ed. 2010, 49, 5519; r) G. Z. Zhang, L. Cui, Y. Z. Wang, L. M. Zhang, J. Am. Chem. Soc. 2010, 132, 1474; Others: s) A. W. Lei, X. Y. Lu, G. S. Liu, Tetrahedron Lett. 2004, 45, 1785; t) M. R. Manzoni, T. P. Zabawa, D. Kasi, S. R. Chemler, Organometallics 2004, 23, 5618; u) F. E. Michael, P. A. Sibbald, B. M. Cochran, Org. Lett. 2008, 10, 793; Reviews: v) A. Minatti, K. Muniz, Chem. Soc. Rev. 2007, 36, 1142; w) E. M. Beccalli, G. Broggini, M. Martinelli, S. Sottocornola, Chem. Rev. 2007, 107, 5318.

[5] S. Nicolai, S. Erard, D. Fernández González, J. Waser, Org. Lett. 2010 , $12,384$.

[6] a) J. S. Prasad, L. S. Liebeskind, Tetrahedron Lett. 1988, 29, 4253; b) L. J. Goossen, J. E. Rauhaus, G. J. Deng, Angew. Chem. 2005, 117, 4110; Angew. Chem., Int. Ed. 2005, 44, 4042; c) L. J. Goossen, K. S. M. Salih, M. Blanchot, Angew. Chem. 2008, 120, 8620; Angew. Chem., Int. Ed. 2008, 47, 8492 .

[7] a) Y. Kozawa, M. Mori, Tetrahedron Lett. 2002, 43, 111; b) Y. Kozawa, M. Mori, J. Org. Chem. 2003, 68, 3064; c) L. Jiang, G. E. Job, A. Klapars, S. L. Buchwald, Org. Lett. 2003, 5, 3667; d) L. L. W. Cheung, A. Yudin, Org. Lett. 2009, 11, 1281.

[8] K. Takami, H. Yorimitsu, K. Oshima, Org. Lett. 2002, 4, 2993.

[9] The exceptional properties of ethynyl benziodoxolone reagents were key for success. a) M. Ochiai, Y. Masaki, M. Shiro, J. Org. Chem. 1991, 56, 551; b) V. V. Zhdankin, C. J. Kuehl, A. P. Krasutsky, J. T. Bolz, A. J. Simonsen, J. Org. Chem. 1996, 61, 654; c) J. P. Brand, J. Charpentier, J. Waser, Angew. Chem. 2009, 121, 9510; Angew. Chem., Int. Ed. 2009, 48, 9346; d) D. Fernández González, J. P. Brand, J. Waser, Chem. Eur. J. 2010, 16, 9457; e) J. P. Brand, J. Waser, Angew. Chem. 2010, 122, 7462; Angew. Chem., Int. Ed. 2010, 49, 7304; For reviews, see: f) T. Wirth, Hypervalent iodine chemistry: modern developments in organic synthesis; Springer: New York, 2003; Vol. 224; g) V. V. Zhdankin, P. J. Stang, Chem. Rev. 2008, 108, 5299; h) J.P. Brand, D. Fernández González, S. Nicolai, J. Waser, Chem. Commun. 2011, 47, 102. hfacac = hexafluoroacetylacetonate.

[10] See supporting information for a complete list of tested conditions.

[11] The in situ generation of $\mathrm{Li}_{2}\left[\mathrm{PdCl}_{4}\right]$ from cheaper $\mathrm{PdCl}_{2}$ and $\mathrm{LiCl}$ was still preferred for preparative reactions. Other metal additives, such as $\mathrm{CuI}$, were not successful, either with hypervalent iodine reagents or alkynyl halides (See table S3 and S4 in supporting information).

[12] a) K. Fagnou, M. Lautens, Angew. Chem. 2002, 114, 26; Angew. Chem., Int. Ed. 2002, 41, 26; b) X. Y. Lu, Top. Catal. 2005, 35, 73.

[13] This result is interesting for further extension of the scope of the reaction. Nevertheless, we decided to focus first on the use of TIPSEBX (2a), as the obtained silyl acetylenes are easily deprotected.

[14] a) J. L. Mokrosz, B. Duszynska, M. H. Paluchowska, Arch. Pharm. 1994, 327, 529; b) S. Butini et al., J. Med. Chem. 2009, 52, 151. See supporting information for full reference $14 \mathrm{~b}$.

[15] See figures $S 1$ and $S 2$ in supporting information. Investigations are currently ongoing to identify the formed intermediate.

[16] a) G. P. Menschikov, Zh. Obshch. Khim. 1946, 16, 1311; b) S. Danishefsky, R. McKee, R. K. Singh, J. Am. Chem. Soc. 1977, 99 , 4783; c) H. Ishibashi, M. Sasaki, T. Taniguchi, Tetrahedron 2008, 64, 7771.

[17] S. Couty, C. Meyer, J. Cossy, Tetrahedron 2009, 65, 1809. 


\section{Heterocycle Synthesis}

Stefano Nicolai, Cyril Piemontesi and Jérôme Waser Page -

Page

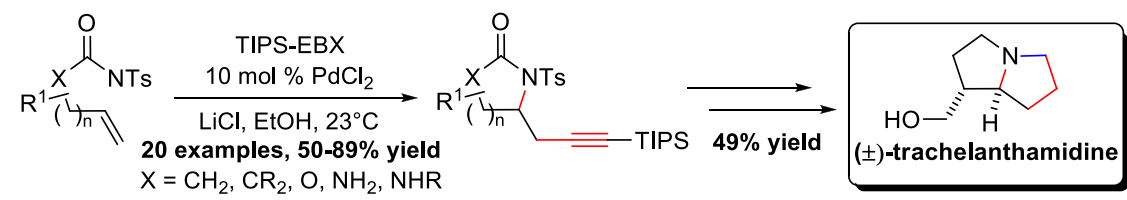

A Palladium-Catalyzed

Aminoalkynylation Strategy towards Bicyclic Heterocycles: Synthesis of Trachelanthamidine.

Sweet Cyclizations: A strategy for the synthesis of pyrrolizidine and indolizidine heterocycles is reported. Olefins were subjected to an intramolecular Pd-catalyzed aminoalkynylation with the hypervalent iodine reagent TIPS-EBX. Tosyl amides, carbamates and ureas were cyclized to form 5- and 6-membered rings in 50-89\% yield. After deprotection, a two step cyclization sequence followed by reduction led to the natural product trachelanthamidine. 


\section{Table of Content}

109 Pages

1. Full Reference 14b

p. S2

2. General Methods

p. S2

3. Preparation of Reagents

p. S2

4. Preparation of Substrates

p. S7

5. Optimization of the Reaction

p. S25

6. Scope of the Reaction

p. S29

7. Deprotection and Second Cyclization

p. $\mathrm{S} 40$

8. Mechanistic Investigations

p. S52

9. Spectra of New Compounds

p. S54 


\section{Full Reference 14b}

Butini, S.; Gemma, S.; Campiani, G.; Franceschini, S.; Trotta, F.; Borriello, M.; Ceres, N.; Ros, S.; Coccone, S. S.; Bernetti, M.; De Angelis, M.; Brindisi, M.; Nacci, V.; Fiorini, I.; Novellino, E.; Cagnotto, A.; Mennini, T.; Sandager-Nielsen, K.; Andreasen, J. T.; ScheelKruger, J.; Mikkelsen, J. D.; Fattorusso, C. J. Med. Chem. 2009, 52, 151.

\section{General Methods}

All reactions were carried out in oven dried glassware under an atmosphere of nitrogen, unless stated otherwise. For quantitative flash chromatography technical grade solvents were used. For flash chromatography for analysis, HPLC grade solvents from Sigma-Aldrich were used. THF, $\mathrm{Et}_{2} \mathrm{O}, \mathrm{CH}_{3} \mathrm{CN}$, toluene, hexane and $\mathrm{CH}_{2} \mathrm{Cl}_{2}$ were dried by passage over activated alumina under nitrogen atmosphere $\left(\mathrm{H}_{2} \mathrm{O}\right.$ content $<30 \mathrm{ppm}$, Karl-Fischer titration $)$. $\mathrm{NEt}_{3}$ and pyridine were distilled under nitrogen from $\mathrm{KOH}$. All chemicals were purchased from Acros, Aldrich, Fluka, VWR, Aplichem or Merck and used as such unless stated otherwise. Chromatographic purification was performed as flash chromatography using Macherey-Nagel silica 40-63, $60 \AA$, using the solvents indicated as eluent with 0.1-0.5 bar pressure. TLC was performed on Merck silica gel 60 F254 TLC glass plates or aluminium plates and visualized with UV light, permanganate stain, CAN stain or Anisaldehyde stain. Melting points were measured on a Büchi B-540 melting point apparatus using open glass capillaries, the data is uncorrected. ${ }^{1} \mathrm{H}-\mathrm{NMR}$ spectra were recorded on a Brucker DPX-400 $400 \mathrm{MHz}$ spectrometer in chloroform- $\mathrm{d}$, DMSO- $\mathrm{d}_{6}, \mathrm{CD}_{2} \mathrm{Cl}_{2}$ or $\mathrm{CD}_{3} \mathrm{OD}$, all signals are reported in ppm with the internal chloroform signal at $7.26 \mathrm{ppm}$, the internal DMSO signal at $2.50 \mathrm{ppm}$, the internal $\mathrm{CD}_{2} \mathrm{Cl}_{2}$ signal at $5.31 \mathrm{ppm}$, or the internal methanol signal at $3.30 \mathrm{ppm}$ as standard. The data is being reported as $(\mathrm{s}=$ singlet, $\mathrm{d}=$ doublet, $\mathrm{t}=$ triplet, $\mathrm{q}=$ quadruplet, $\mathrm{qi}=$ quintet, $\mathrm{m}=$ multiplet or unresolved, br $=$ broad signal, coupling constant(s) in Hz, integration; interpretation). ${ }^{13} \mathrm{C}$-NMR spectra were recorded with ${ }^{1} \mathrm{H}$-decoupling on a Brucker DPX-400 $100 \mathrm{MHz}$ spectrometer in chloroform-d, DMSO- $\mathrm{d}_{6}, \mathrm{CD}_{2} \mathrm{Cl}_{2}$ or $\mathrm{CD}_{3} \mathrm{OD}$, all signals are reported in ppm with the internal chloroform signal at $77.0 \mathrm{ppm}$, the internal DMSO signal at $39.5 \mathrm{ppm}$, the internal $\mathrm{CD}_{2} \mathrm{Cl}_{2}$ signal at $53.5 \mathrm{ppm}$ or the internal methanol signal at $49.0 \mathrm{ppm}$ as standard. Infrared spectra were recorded on a JASCO FT-IR B4100 spectrophotometer with an ATR PRO410-S and a ZnSe prisma and are reported as $\mathrm{cm}^{-1}(\mathrm{w}=$ weak, $\mathrm{m}=$ medium, $\mathrm{s}=$ strong, $\mathrm{sh}=$ shoulder). Gas chromatographic and low resolution mass spectrometric measurements were performed on a Perkin-Elmer Clarus 600 gas chromatographer and mass spectrometer using a Perkin-Elmer Elite fused silica column (length: $30 \mathrm{~m}$, diameter: $0.32 \mathrm{~mm}$ ) and Helium as carrier gas. High resolution mass spectrometric measurements were performed by the mass spectrometry service of ISIC at the EPFL on a MICROMASS (ESI) Q-TOF Ultima API. HPLC measurement were done on a JASCO HPLC system with an AS2055 Autosampler, a PU 2089 Pump, a UV 2075 detector and a SEDEX 85 (SEDERE) detector using a CHIRALPAK IC column from DAICEL Chemical Industries Ltd. HPLC grade solvents from Sigma-Aldrich were used.

\section{Preparation of Reagents}

\section{Phenyl(triisopropylsilyl)iodonium triflate (18)}


<smiles>CC(=O)OI(OC(C)=O)c1ccccc1</smiles>

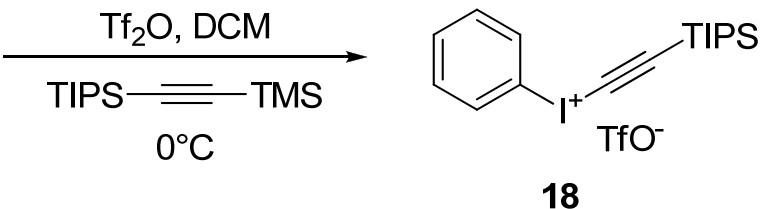

Following a slight modification of the reported procedure, ${ }^{[1]}$ phenyliodonium diacetate (17) (2.53 g, $7.85 \mathrm{mmol}, 1.00$ equiv) was diluted with DCM $(7 \mathrm{~mL})$ and the mixture was stirred for 5 minutes. $\mathrm{Tf}_{2} \mathrm{O}(0.60 \mathrm{~mL}, 3.9 \mathrm{mmol}, 0.50$ equiv. $)$ was added dropwise at $0{ }^{\circ} \mathrm{C}$ and the resulting yellow mixture was stirred $30 \mathrm{~min}$. (Trimethylsilyl)(triisopropylsilyl)acetylene $(2.00$ $\mathrm{g}, 7.86 \mathrm{mmol}, 1.00$ equiv) was added and the mixture was then stirred $2 \mathrm{~h}$. Water was then added $(30 \mathrm{~mL})$ followed by extraction of the aqueous layer with DCM $(2 \times 30 \mathrm{~mL})$. The combined organic layers were dried over $\mathrm{MgSO}_{4}$, filtered and the solvent was evaporated under reduced pressure. The resulting solid was triturated in hexane $(10 \mathrm{~mL})$. Filtration and removal of solvent in vacuo afforded phenyl(triisopropylsilyl)iodonium triflate (18) (2.90 g, $11.2 \mathrm{mmol}, 70 \%$ yield) as a colorless solid.

${ }^{1} \mathrm{H}$ NMR (400 MHz, $\left.\mathrm{CDCl}_{3}\right) \delta 8.09(\mathrm{~m}, 2 \mathrm{H}, \mathrm{ArH}), 7.65(\mathrm{~m}, 1 \mathrm{H}, \mathrm{Ar} H), 7.52(\mathrm{~m}, 2 \mathrm{H}, \mathrm{Ar} H)$, 1.15-1.01 (m, $21 \mathrm{H}$, TIPS); ${ }^{13} \mathrm{C}$ NMR (100 MHz, $\left.\mathrm{CDCl}_{3}\right) \delta 133.7,132.5,132.4,119.7,117.6$, 117.6, 44.9, 18.3, 11.1; IR v $3288(\mathrm{w}), 3088(\mathrm{~m}), 2949$ (m), $2894(\mathrm{~m}), 2869(\mathrm{w}), 1563(\mathrm{~m})$, 1467 (w), 1451 (w), 1388 (w), 1281 (s), 1236 (s), 1221 (s), 1174 (s), 1068 (w), 1028 (s), 988 (m), $916(\mathrm{~m}), 884(\mathrm{~m}), 736$ (s), $679(\mathrm{~m}), 639$ (s); Melting point: $109-114^{\circ} \mathrm{C}$. HRMS (ESI) calcd for $\mathrm{C}_{17} \mathrm{H}_{26} \mathrm{ISi}^{+}$(M-OTf) 385.0843; found 385.0812; the reported values corresponded to the ones in literature. ${ }^{[2]}$

\section{1-Hydroxy-1,2-benziodoxol-3-(1H)-one (20)}<smiles>O=C(O)c1ccccc1I</smiles>

19

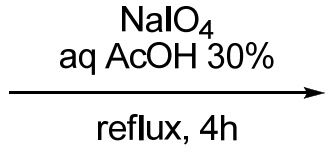

reflux, $4 \mathrm{~h}$<smiles>O=C1OI(O)c2ccccc21</smiles>

20

Following the reported procedure, ${ }^{[3]} \mathrm{NaIO}_{4}(7.24 \mathrm{~g}, 33.8 \mathrm{mmol}, 1.05$ equiv) and 2iodobenzoic acid (19) (8.00 g, $32.2 \mathrm{mmol}, 1.00$ equiv) were suspended in 30\% (v:v) aq. $\mathrm{AcOH}(48 \mathrm{~mL})$. The mixture was vigorously stirred and refluxed for $4 \mathrm{~h}$. The reaction mixture was then diluted with cold water $(180 \mathrm{~mL})$ and allowed to cool to rt, protecting it from light. After $1 \mathrm{~h}$, the crude product was collected by filtration, washed on the filter with ice water $(3 \times 20 \mathrm{~mL})$ and acetone $(3 \times 20 \mathrm{~mL})$, and air-dried in the dark to give the pure product $20(8.3 \mathrm{~g}, 31 \mathrm{mmol}, 98 \%)$ as a colorless solid.

${ }^{1} \mathrm{H}$ NMR $\left(400 \mathrm{MHz},\left(\mathrm{CD}_{3}\right)_{2} \mathrm{SO}\right) \delta 8.02(\mathrm{dd}, 1 \mathrm{H}, J=7.7,1.4 \mathrm{~Hz}, \mathrm{Ar} H), 7.97(\mathrm{~m}, 1 \mathrm{H}, \mathrm{Ar} H)$, $7.85(\mathrm{dd}, 1 \mathrm{H}, J=8.2,0.7 \mathrm{~Hz}, \operatorname{Ar} H), 7.71(\mathrm{td}, 1 \mathrm{H}, J=7.6,1.2 \mathrm{~Hz}, \operatorname{Ar} H) ;{ }^{13} \mathrm{C} \mathrm{NMR}(100$

[1] T. Kitamura, M. Kotani, Y. Fujiwara, Synthesis 1998, 10, 1416.

[2] J. P. Brand, J. Waser, Angew. Chem., Int. Ed. 2010, 49, 7304.

[3] L. Kraszkiewicz, L. Skulski, Arkivoc. 2003, 6, 120. 
$\left.\mathrm{MHz},\left(\mathrm{CD}_{3}\right)_{2} \mathrm{SO}\right) \delta 167.7,134.5,131.5,131.1,130.4,126.3,120.4$; IR v $3083(\mathrm{w}), 3060(\mathrm{w})$, 2867 (w), 2402 (w), 1601 (m), 1585 (m), 1564 (m), 1440 (m), 1338 (s), 1302 (m), 1148 (m), $1018(\mathrm{w}), 834(\mathrm{~m}), 798(\mathrm{w}), 740(\mathrm{~s}), 694(\mathrm{~s}), 674(\mathrm{~m}), 649(\mathrm{~m})$; the reported values correspond to the ones in literature. ${ }^{[3]}$

\section{Triisopropylsilyl trimethylsilylacetylene (22)}

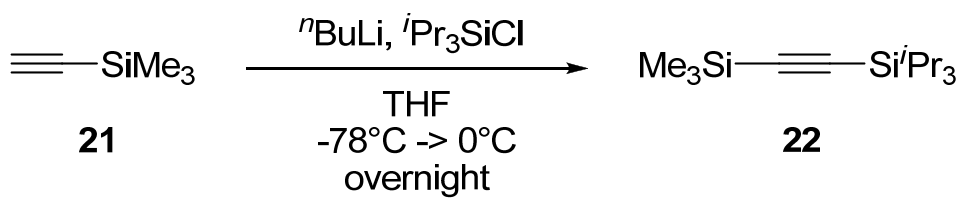

Following a reported procedure ${ }^{[4]} n$-butyllithium $(2.5 \mathrm{M}$ in hexanes, $12.0 \mathrm{~mL}, 29.9 \mathrm{mmol}$, 0.98 equiv) was added dropwise to a stirred solution of ethynyltrimethylsilane (21) $(3.0 \mathrm{~g}, 30$ mmol, 1.0 equiv) in THF $(48 \mathrm{~mL})$ at $-78{ }^{\circ} \mathrm{C}$. The mixture was then warmed to $0{ }^{\circ} \mathrm{C}$ and stirred for $5 \mathrm{~min}$. The mixture was then cooled back to $-78{ }^{\circ} \mathrm{C}$ and chlorotriisopropylsilane (6.4 mL, $30 \mathrm{mmol}, 1.0$ equiv) was added dropwise. The mixture was then allowed to warm to room temperature and stirred overnight. A saturated solution of ammonium chloride $(40 \mathrm{~mL})$ was added, and the reaction mixture was extracted with diethyl ether $(2 \times 60 \mathrm{~mL})$. The organic layer was washed with water and brine, then dried over $\mathrm{MgSO}_{4}$, filtered and concentrated under reduced pressure to obtain a colorless liquid which was further purified by Kugelrohr distillation $\left(56-57^{\circ} \mathrm{C} / 0.25 \mathrm{mmHg}\right)$ to yield 22 ( $7.16 \mathrm{~g}, 28.0 \mathrm{mmol}, 92 \%$ yield $)$ as a colorless liquid.

${ }^{1} \mathrm{H}$ NMR (400 MHz, $\left.\mathrm{CDCl}_{3}\right) \delta 1.08$ (m, $\left.21 \mathrm{H}, \mathrm{TIPS}\right), 0.18$ (s, $\left.9 \mathrm{H}, \mathrm{TMS}\right)$. IR $v 2959$ (m), 2944 (m), 2896 (w), 2867 (m), 1464 (w), 1385 (w), 1250 (m), 996 (w), 842 (s), 764 (s), 675 $(\mathrm{m}), 660(\mathrm{~m})$. Characterization data of 22 corresponded to the literature values. ${ }^{[4]}$

\section{1-[(Triiso-propylsilyl)ethynyl]-1,2-benziodoxol-3(1H)-one (TIPS-EBX, 2a)}<smiles>O=C1OI(O)c2ccccc21</smiles>

20

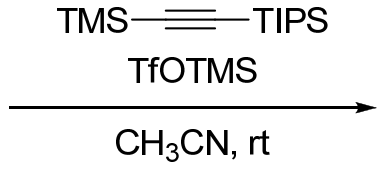

$\mathrm{CH}_{3} \mathrm{CN}, \mathrm{rt}$<smiles>O=C1OI(C#CS[In])c2ccccc21</smiles>

$2 a$

Following a reported procedure, ${ }^{[2]}$ 2-iodosylbenzoic acid (20) (21.7 g, 82.0 mmol, 1.0 equiv) was charged in oven-dried three-neck 1L flask equipped with a magnetic stirrer. After 3 vacuum/nitrogen cycles, anhydrous acetonitrile $(500 \mathrm{~mL})$ was added via canula and cooled to $4{ }^{\circ} \mathrm{C}$. Trimethylsilyltriflate $(16.4 \mathrm{~mL}, 90.0 \mathrm{mmol}, 1.1$ equiv) was added dropwise via a dropping funnel over $30 \mathrm{~min}$ (no temperature increase was observed). After $15 \mathrm{~min}$, (trimethylsilyl)(triisopropylsilyl)acetylene (22) (23.0 g, $90.0 \mathrm{mmol}, 1.1$ equiv) was added via canula over $15 \mathrm{~min}$ (no temperature increase was observed). After $30 \mathrm{~min}$, the suspension became an orange solution. After $10 \mathrm{~min}$, pyridine $(7.0 \mathrm{~mL}, 90 \mathrm{mmol}, 1.1$ equiv) was added via syringe. After $15 \mathrm{~min}$, the reaction mixture was transferred in a one-neck 1L flask and reduced under vacuum until a solid was obtained. The solid was dissolved in DCM (200 mL)

[4] C J. Helal, P. A. Magriotis, E. J. Corey, J. Am. Chem. Soc. 1996, 118, 10938. 
and transferred in a 1L separatory funnel. The organic layer was added and washed with $1 \mathrm{M}$ $\mathrm{HCl}(200 \mathrm{~mL})$ and the aqueous layer was extracted with $\mathrm{CH}_{2} \mathrm{Cl}_{2}(200 \mathrm{~mL})$. The organic layers were combined, washed with a saturated solution of $\mathrm{NaHCO}_{3}(2 \times 200 \mathrm{~mL})$, dried over $\mathrm{MgSO}_{4}$, filtered and the solvent was evaporated under reduced pressure. Recrystallization from acetonitrile ( $c a 120 \mathrm{~mL}$ ) afforded $2(30.1 \mathrm{~g}, 70.2 \mathrm{mmol}, 86 \%)$ as colorless cristals.

${ }^{1} \mathrm{H}$ NMR (400 MHz, $\left.\mathrm{CDCl}_{3}\right) \delta 8.44(\mathrm{~m}, 1 \mathrm{H}, \mathrm{ArH}), 8.29(\mathrm{~m}, 1 \mathrm{H}, \mathrm{ArH}), 7.77$ (m, $\left.2 \mathrm{H}, \mathrm{ArH}\right), 1.16$ (m, $21 \mathrm{H}, \mathrm{TIPS}) .{ }^{13} \mathrm{C} \mathrm{NMR}\left(100 \mathrm{MHz}, \mathrm{CDCl}_{3}\right) \delta 166.4,134.6,132.3,131.4,131.4,126.1,115.6$, 114.1, 64.6, 18.4, 11.1. IR $v 2943$ (m), 2865 (m), $1716(\mathrm{~m}), 1618(\mathrm{~m}), 1604(\mathrm{~s}), 1584(\mathrm{~m}), 1557$ (m), 1465 (m), 1439 (w), 1349 (m), $1291(\mathrm{~m}), 1270$ (w), 1244 (m), 1140 (m), 1016 (m), 999 (m), $883(\mathrm{~m}), 833(\mathrm{~m}), 742(\mathrm{~m}), 702(\mathrm{~s}), 636(\mathrm{~m})$; Melting point $(\mathrm{Dec}) 170-.176^{\circ} \mathrm{C}$; characterization data of 2 a corresponded to the literature values. ${ }^{[2]}$

\section{1-[(Trimethylsilyl)ethynyl]-1,2-benziodoxol-3(1H)-one (TMS-EBX, 2b)}<smiles>O=C1OI(O)c2ccccc21</smiles>

20

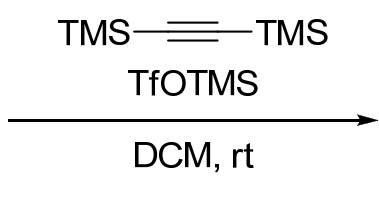
${ }^{[2]}$ trimethylsilyl triflate $(5.54 \mathrm{~mL}, 30.7 \mathrm{mmol}, 1.1$ equiv $)$ was added to a suspension of 2-iodosylbenzoic acid (20) (7.36 g, $28.0 \mathrm{mmol}, 1.0$ equiv) in DCM $(85 \mathrm{~mL})$ at $\mathrm{rt}$. The resulting yellow mixture was stirred for $1 \mathrm{~h}$, followed by the dropwise addition of bis(trimethylsilyl)acetylene $(6.98 \mathrm{~mL}, 30.7 \mathrm{mmol}, 1.1$ equiv). The resulting suspension was stirred for $6 \mathrm{~h}$ at $\mathrm{rt}$, during this time a colorless solid was formed. A saturated solution of $\mathrm{NaHCO}_{3}$ was then added and the mixture was stirred vigorously until complete solubilization of the colorless solid. The two layers were separated and the combined organic extracts were washed with sat. $\mathrm{NaHCO}_{3}$, dried over $\mathrm{MgSO}_{4}$, filtered and evaporated under reduced pressure. Recrystallization from acetonitrile $(50 \mathrm{~mL})$ afforded $\mathbf{2 b}$ (7.17 g, $20.8 \mathrm{mmol}, 74 \%)$ as a colorless solid.

${ }^{1} \mathrm{H}$ NMR $\left(400 \mathrm{MHz}, \mathrm{CDCl}_{3}\right) \delta 8.42(\mathrm{dd}, 1 \mathrm{H}, J=6.4,1.9 \mathrm{~Hz}, \mathrm{Ar} H), 8.19(\mathrm{~m}, 1 \mathrm{H}, \mathrm{ArH}), 7.78(\mathrm{~m}$, $2 \mathrm{H}, \mathrm{ArH}), 0.32$ (s, $9 \mathrm{H}, \mathrm{TMS}) ;{ }^{13} \mathrm{C} \mathrm{NMR}\left(100 \mathrm{MHz}, \mathrm{CDCl}_{3}\right) \delta 166.4,134.9,132.6,131.7,131.4$, 126.1, 117.2, 115.4, 64.2, -0.5; IR v 3389 (w), 2967 (w), 1617 (s), 1609 (s), 1562 (m), 1440 (w), $1350(\mathrm{~m}), 1304$ (w), 1254 (w), 1246 (w), 1112 (w), 1008 (w), 852 (s), 746 (m), 698 (m), 639 (m); Melting point (Dec.): $143-145^{\circ} \mathrm{C}$; the reported values corresponded to the ones in literature. ${ }^{2}$

\section{1-(Phenylethynyl)-1,2-benziodoxol-3(1H)-one (Ph-EBX, 2c)}

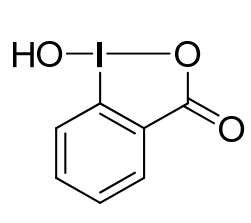

20

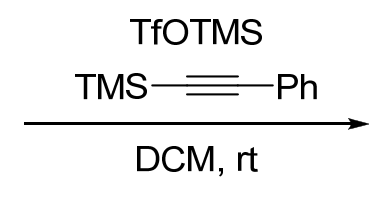
Following a reported procedure, ${ }^{[2]}$ trimethylsilyl triflate $(7.50 \mathrm{~mL}, 41.5 \mathrm{mmol}, 1.1$ equiv $)$ was
added to a suspension of 2-iodosylbenzoic acid $\mathbf{( 2 0})(10.0 \mathrm{~g}, 37.7 \mathrm{mmol}, 1$ equiv) in DCM 
$(100 \mathrm{~mL})$ at $\mathrm{rt}$. The resulting yellow mixture was stirred for $1 \mathrm{~h}$, followed by the dropwise addition of trimethyl(phenylethynyl)silane $(8.10 \mathrm{~mL}, 41.5 \mathrm{mmol}, 1.1$ equiv) (slightly exothermic). The resulting suspension was stirred for $6 \mathrm{~h}$ at $\mathrm{rt}$, during this time a white solid was formed. A saturated solution of $\mathrm{NaHCO}_{3}(100 \mathrm{~mL})$ was then added and the mixture was stirred vigorously. The resulting suspension was filtered on porosity 4 glass filter. The two layers of the mother liquors were separated and the organic layer was washed with sat. $\mathrm{NaHCO}_{3}$, dried over $\mathrm{MgSO}_{4}$, filtered and evaporated under reduced pressure. The resulting mixture was combined with the solid obtained by filtration and boiled in $\mathrm{CH}_{3} \mathrm{CN}(300 \mathrm{~mL})$. The mixture was cooled down, the formed solid was collected and dried under high vacuum to afford $2 \mathrm{c}(6.08 \mathrm{~g}, 17.4 \mathrm{mmol}, 46 \%)$ as a colorless solid

${ }^{1} \mathrm{H}$ NMR (400 MHz, $\left.\mathrm{CDCl}_{3}\right) \delta 8.46(\mathrm{~m}, 1 \mathrm{H}, \mathrm{Ar} H), 8.28(\mathrm{~m}, 1 \mathrm{H}, \operatorname{Ar} H), 7.80(\mathrm{~m}, 2 \mathrm{H}, \operatorname{Ar} H)$, $7.63(\mathrm{~m}, 2 \mathrm{H}, \mathrm{Ar} H), 7.48$ (m, $3 \mathrm{H}, \mathrm{ArH}) .{ }^{13} \mathrm{C} \mathrm{NMR}\left(101 \mathrm{MHz}, \mathrm{CDCl}_{3}\right) \delta 163.9,134.9,132.9$, 132.5, 131.6, 131.3, 130.8, 128.8, 126.2, 120.5, 116.2, 106.6, 50.2; IR $3735(\mathrm{w}), 3649(\mathrm{w})$, $3096(\mathrm{w}), 3064(\mathrm{w}), 2150(\mathrm{w}), 1685$ (m), 1653 (s), 1635 (m), 1623 (s), $1587(\mathrm{w}), 1570(\mathrm{w})$, 1559 (m), 1542 (w), 1508 (w), 1489 (w), 1457 (w), 1338 (w), 1330 (w), $1291(\mathrm{~m}), 1241$ (w), 1215 (w), 1193 (w), 1179 (w), 1167 (w), 1160 (w), 1149 (w), 1123 (w), 1019 (w), 1005 (w), 996 (w), $971(\mathrm{w}), 960(\mathrm{w}), 913$ (w), 743 (s), 691 (m), 658 (w), 650 (m), 634 (m), 615 (s); Melting point (Dec.) $147-156^{\circ} \mathrm{C}$; HRMS (ESI) calcd for $\mathrm{C}_{15} \mathrm{H}_{10} \mathrm{IO}_{2}{ }^{+}[\mathrm{M}+\mathrm{H}]^{+} 348.9720$; found 348.9716 .

\section{2-Iodo-1-triisopropylsilyl acetylene (24)}

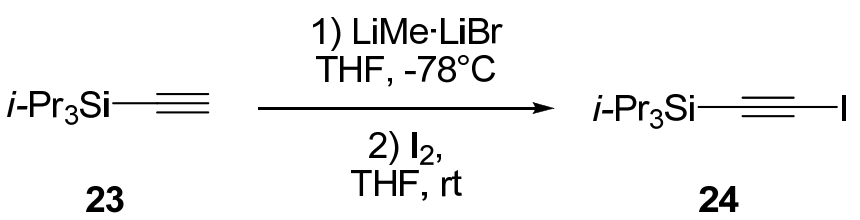

Following a reported procedure ${ }^{[5]} \mathrm{MeLi} \cdot \mathrm{LiBr}(1.5 \mathrm{M}$ in diethyl ether, 1.1.mL, $1.6 \mathrm{mmol}, 1.0$ equiv) was added to a stirred solution of triisopropylsilylacetylene (23) $(0.36 \mathrm{~mL}, 1.6 \mathrm{mmol}$, 1.0 equiv) in dry THF $(1.8 \mathrm{~mL})$, cooled at $-78{ }^{\circ} \mathrm{C}$, and the mixture was allowed to react for 1 $\mathrm{h}$ at that temperature. A solution of $\mathrm{I}_{2}(457 \mathrm{mg}, 1.80 \mathrm{mmol}, 1.25$ equiv $)$ in dry THF $(2.7 \mathrm{~mL})$ was then added dropwise and the mixture was stirred for $1.5 \mathrm{~h}$ at $-78^{\circ} \mathrm{C}$. The mixture was then diluted with brine $(6 \mathrm{~mL})$ and the aqueous layer was extracted with ether $(3 \times 10 \mathrm{~mL})$. The combined organic layers were washed with a saturated aqueous solution of $\mathrm{Na}_{2} \mathrm{~S}_{2} \mathrm{O}_{3}(3 \mathrm{x}$ $20 \mathrm{~mL}$ ), dried over $\mathrm{MgSO}_{4}$ and concentrated under reduced pressure. Purification by column chromatography ( $\mathrm{SiO}_{2}$, hexane) afforded 2-iodo-1-triisopropylsilyl acetylene (24) (470 mg, $1.52 \mathrm{mmol}, 94 \%$ yield) as a colorless oil.

${ }^{1} \mathrm{H}$ NMR (400 MHz, $\mathrm{CDCl}_{3}$ ) $\delta 1.10-1.04$ (m, $\left.21 \mathrm{H}, \mathrm{TIPS}\right) ;{ }^{13} \mathrm{C} \mathrm{NMR}\left(100 \mathrm{MHz}, \mathrm{CDCl}_{3}\right) \delta 100.8,18.5$, 11.4 (one acetylene carbon was not resolved); the reported values correspond to the ones in literature. ${ }^{[5]}$

\section{2-Bromo-1-triisopropylsilyl acetylene (25)}

[5] S. López, F. Fernández-Trillo, P. Midón, L. Castedo, C. Saá J. Org. Chem., 2005, 70, 6346. 


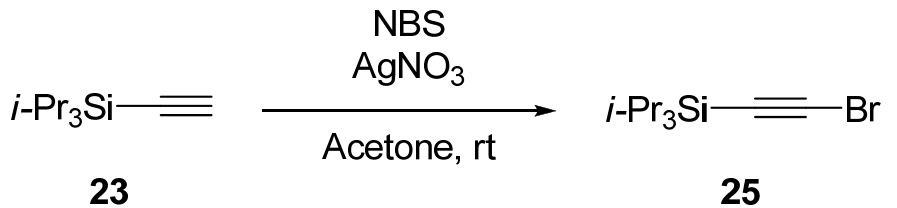

Following a reported procedure ${ }^{[6]}$ triisopropylsilylacetylene $(\mathbf{2 3})(813 \mathrm{mg}, 4.45 \mathrm{mmol}, 1.00$ equiv) was dissolved in acetone $(30 \mathrm{~mL}) . N$-bromosuccinimide $(925 \mathrm{mg}, 5.19 \mathrm{mmol}, 1.16$ equiv) was added, followed by $\mathrm{AgNO}_{3}$ ( $76 \mathrm{mg}, 0.44 \mathrm{mmol}, 0.1$ equiv). The resulting mixture was stirred at room temperature for $3 \mathrm{~h}$ and it was then poured onto ice. After ice being allowed to melt, the aqueous layer was extracted with pentane $(3 \times 30 \mathrm{~mL})$. The combined organic layers were dried over $\mathrm{MgSO}_{4}$, filtered and concentrated in vacuo to afford pure 2bromo-1-triisopropylsilyl acetylene (25) (1.16 g, $4.43 \mathrm{mmol}, 99 \%)$ as a colorless oil.

${ }^{1} \mathrm{H}$ NMR (400 MHz, $\mathrm{CDCl}_{3}$ ) $\delta$ 1.20-0.97 (m, $21 \mathrm{H}$, TIPS); ${ }^{13} \mathrm{C}$ NMR $\left(101 \mathrm{MHz}, \mathrm{CDCl}_{3}\right) \delta 83.5,61.7$, $18.5,11.3$; the reported values corresponded to the ones in literature. ${ }^{[6]}$

\section{Preparation of Substrates}

\section{$N$-Tosylpent-4-enamide (1a)}

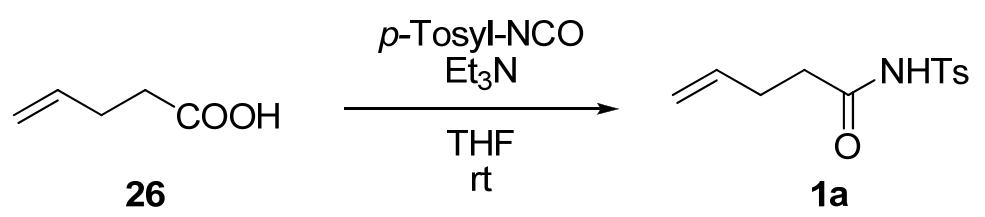

Following a reported procedure ${ }^{[7]} p$-tosyl isocyanate $(1.18 \mathrm{~g}, 6.00 \mathrm{mmol}, 1.00$ equiv) was added to a solution of 4-pentenoic acid 26 (0.60 g, $6.0 \mathrm{mmol}, 1.0$ equiv) in THF (12 mL). After stirring the resulting clear solution at $\mathrm{rt}$ for $10 \mathrm{~min}$, triethyl amine $(0.84 \mathrm{~mL}, 6.0 \mathrm{mmol}$, 1.0 equiv) was added dropwise, with release of gas. After $1 \mathrm{~h}$, the mixture was diluted with EtOAc $(12 \mathrm{~mL})$ and washed with $2 \mathrm{M} \mathrm{HCl}(12 \mathrm{~mL})$ and $\mathrm{NaCl}$ (saturated solution, $12 \mathrm{~mL}$ ). The organic layer was dried over $\mathrm{MgSO}_{4}$, filtered and concentrated in vacuo. The resulting crude solid was dissolved in $\mathrm{Et}_{2} \mathrm{O}$ in order to obtain a saturated solution and hexane was added to precipitate the pure tosyl amide. $N$-tosylpent-4-enamide (1a) was obtained as a colorless, crystalline solid (1.49 g, $5.87 \mathrm{mmol}, 98 \%$ yield).

$\mathrm{R}_{\mathrm{f}} 0.78(\mathrm{DCM} / \mathrm{EtOAc} 9 / 1) ;{ }^{1} \mathrm{H}$ NMR $\left(400 \mathrm{MHz}, \mathrm{CDCl}_{3}\right) \delta 8.10($ br s, $1 \mathrm{H}, \mathrm{NH}), 7.92(\mathrm{~m}, 2 \mathrm{H}$, tosyl $\mathrm{CH}), 7.33(\mathrm{~m}, 2 \mathrm{H}$, tosyl $\mathrm{CH}), 5.74\left(\mathrm{~m}, 1 \mathrm{H}, \mathrm{CH}=\mathrm{CH}_{2}\right), 5.05-4.95\left(\mathrm{~m}, 2 \mathrm{H}, \mathrm{CH}=\mathrm{CH}_{2}\right)$, $2.44\left(\mathrm{~s}, 3 \mathrm{H}\right.$, tosyl $\left.\mathrm{CH}_{3}\right), 2.40-2.26\left(\mathrm{~m}, 4 \mathrm{H}, \mathrm{CH}_{2} \mathrm{CH}_{2}\right) ;{ }^{13} \mathrm{C} \mathrm{NMR}\left(101 \mathrm{MHz}, \mathrm{CDCl}_{3}\right) \delta 170.1$, 145.2, 135.7, 135.4, 129.6, 128.3, 116.3, 35.4, 28.1, 21.7; IR 3242 (m), $2980(\mathrm{w}), 2922(\mathrm{w})$, 2867 (w), 1723 (m), 1705 (m), 1643 (w), 1598 (w), 1491 (w), 1441 (s), 1344 (m), 1307 (w), $1295(\mathrm{w}), 1211(\mathrm{w}), 1210(\mathrm{w}), 1172(\mathrm{~s}), 1087$ (s), $920(\mathrm{w}), 855(\mathrm{~m}), 816(\mathrm{w}), 739(\mathrm{w}), 708$ $(\mathrm{w}), 661(\mathrm{~m}), 649(\mathrm{w}), 622(\mathrm{w})$; Melting point: expected: $88.0-89.0$; found: $89.5-91.7^{\circ} \mathrm{C}$; the reported values for 1 a corresponded to the ones in literature. ${ }^{[7]}$

\section{$N$-(4-Methoxyphenylsulfonyl)pent-4-enamide (1b)}

[6] M. X. Jiang, M. Rawat, W. D. Wulff, J. Am. Chem. Soc. 2004, 126, 5970.

[7] P. Pinho, A. J. Minnaard, B. L. Feringa, Org. Lett. 2003, 5, 259. 


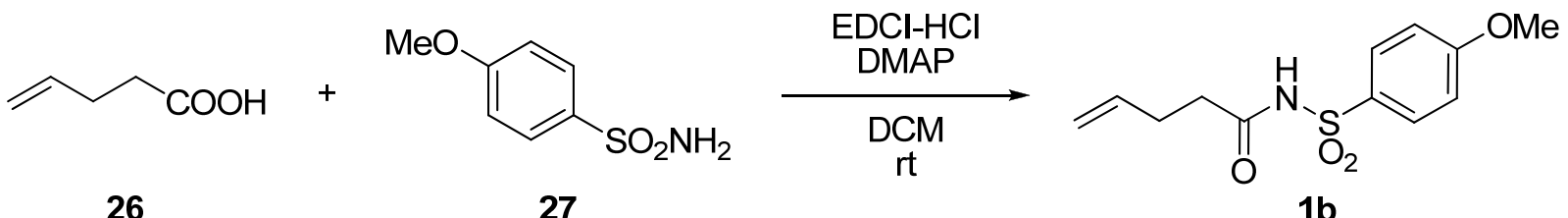

Following a slightly modified version of a reported procedure,${ }^{[8]}$ DMAP (1.32 g, 10.8 mmol, 3.60 equiv) was added to a suspension of $\mathrm{EDCI} \cdot \mathrm{HCl}(920 \mathrm{mg}, 4.80 \mathrm{mmol}, 1.30$ equiv) in DCM $(7.5 \mathrm{~mL})$. The mixture was stirred at $\mathrm{rt}$ until all the solids dissolved and then it was cooled to $0^{\circ} \mathrm{C}$. 4-pentenoic acid (26) $(300 \mathrm{mg}, 3.00 \mathrm{mmol}, 1.00$ equiv) was added, followed by $p$-methoxybenzenesulfonamide (27) $(674 \mathrm{mg}, 3.60 \mathrm{mmol}, 1.20$ equiv) and the mixture was stirred at $\mathrm{rt}$ for $24 \mathrm{~h} . \mathrm{Et}_{2} \mathrm{O}(10 \mathrm{~mL})$ was then added and the organic mixture was washed with $2 \mathrm{~N} \mathrm{HCl}(30 \mathrm{~mL})$. The aqueous layer was extracted with EtOAc $(3 \times 20 \mathrm{~mL})$. The combined organic layers were washed with brine, dried over $\mathrm{MgSO}_{4}$, filtered and concentrated in vacuo. Purification by column chromatography $\left(\mathrm{SiO}_{2}, \mathrm{DCM} / \mathrm{EtOAc} / \mathrm{AcOH} 90 / 10 / 1\right)$ afforded $N$-(4methoxyphenylsulfonyl)pent-4-enamide (1b) (527 mg, $1.85 \mathrm{mmol}, 95 \%$ yield) as a colorless solid.

$\mathrm{R}_{\mathrm{f}} 0.21(\mathrm{PET} / \mathrm{EtOAc} 4 / 1) ;{ }^{1} \mathrm{H}$ NMR $\left(400 \mathrm{MHz}, \mathrm{CDCl}_{3}\right) \delta 8.59$ (br s, $\left.1 \mathrm{H}, \mathrm{NH}\right), 7.99(\mathrm{~m}, 2 \mathrm{H}$, tosyl $\mathrm{CH}), 7.00(\mathrm{~m}, 2 \mathrm{H}$, tosyl $\mathrm{CH}), 5.72\left(\mathrm{~m}, 1 \mathrm{H}, \mathrm{CH}=\mathrm{CH}_{2}\right), 5.02-4.93\left(\mathrm{~m}, 2 \mathrm{H}, \mathrm{CH}=\mathrm{CH}_{2}\right)$, $3.88\left(\mathrm{~s}, 3 \mathrm{H}, \mathrm{OCH}_{3}\right), 2.39-2.27\left(\mathrm{~m}, 4 \mathrm{H}, \mathrm{CH}_{2} \mathrm{CH}_{2}\right) ;{ }^{13} \mathrm{C} \mathrm{NMR}\left(101 \mathrm{MHz}, \mathrm{CDCl}_{3}\right) \delta 170.0$, 164.0, 135.8, 130.7, 130.7, 130.7, 129.7, 116.3, 114.1, 55.7, 35.4, 28.1; IR 3596 (w), 3595 (w), $3345(\mathrm{w}), 3249(\mathrm{w}), 3081(\mathrm{w}), 3080(\mathrm{w}), 3014(\mathrm{w}), 3009(\mathrm{w}), 2906(\mathrm{w}), 2880(\mathrm{w}), 1798$ (w), 1774 (w), 1756 (w), 1719 (m), 1643 (w), 1596 (s), 1580 (m), 1499 (m), 1440 (s), 1415 (m), 1342 (m), $1312(\mathrm{~m}), 1263$ (s), $1216(\mathrm{w}), 1210(\mathrm{w}), 1188(\mathrm{w}), 1165$ (s), $1115(\mathrm{~m}), 1088$ (s), $1027(\mathrm{~m}), 1008(\mathrm{w}), 977(\mathrm{w}), 967(\mathrm{w}), 954(\mathrm{w}), 926(\mathrm{w}), 912(\mathrm{~m}), 855(\mathrm{~s}), 835(\mathrm{~s}), 802$ (m), $783(\mathrm{w}), 759(\mathrm{w}), 730(\mathrm{~m}), 711(\mathrm{w}), 689(\mathrm{w}), 676(\mathrm{w}), 666(\mathrm{w}), 650(\mathrm{w}), 627(\mathrm{w}), 605$ (w); Melting point: $73.3-75.8^{\circ} \mathrm{C}$; HRMS (ESI) calcd for $\mathrm{C}_{12} \mathrm{H}_{16} \mathrm{NO}_{4} \mathrm{~S}^{+}[\mathrm{M}+\mathrm{H}]^{+} 270.0795$; found 270.0802 .

\section{$N$-(4-Nitrophenylsulfonyl)pent-4-enamide (1c)}

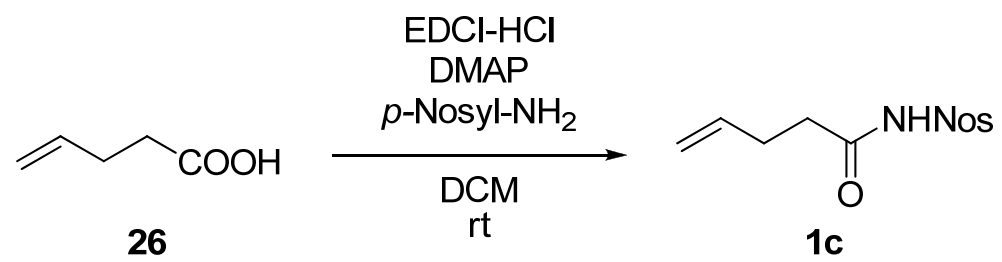

Following a slightly modified version of a reported procedure,${ }^{[8]}$ DMAP (586 mg, $4.80 \mathrm{mmol}$, 2.40 equiv) was added to a suspension of $\mathrm{EDCI} \cdot \mathrm{HCl}(498 \mathrm{mg}, 2.60 \mathrm{mmol}, 1.30$ equiv) in $\operatorname{DCM}(5 \mathrm{~mL})$. The mixture was stirred at room temperature until all the solids dissolved and then it was cooled to $0^{\circ} \mathrm{C}$. 4-pentenoic acid (26) (200 mg, $2.00 \mathrm{mmol}, 1.00$ equiv) was added, followed by $p$-nitrobenzenesulfonamide (485 $\mathrm{mg}, 2.40 \mathrm{mmol}, 1.20$ equiv) and the mixture was stirred at $\mathrm{rt}$ for $24 \mathrm{~h}$. $\mathrm{Et}_{2} \mathrm{O}(10 \mathrm{~mL})$ was then added and the organic mixture was washed with $2 \mathrm{~N} \mathrm{HCl}(15 \mathrm{~mL})$. The aqueous layer was extracted with EtOAc $(3 \times 15 \mathrm{~mL})$. The

[8] M. R. Manzoni, T. P. Zabawa, D. Kasi, S. R. Chemler, Organometallics 2004, 23, 5618. 
combined organic layers were washed with brine, dried over $\mathrm{MgSO}_{4}$, filtered and concentrated in vacuo. Purification by column chromatography $\left(\mathrm{SiO}_{2}, \mathrm{DCM} / \mathrm{EtOAc} 90 / 10\right.$ to 60/40) afforded $N$-(4-nitrophenylsulfonyl)pent-4-enamide (1c) $(527 \mathrm{mg}, 1.85 \mathrm{mmol}, 95 \%$ yield) as a colorless solid.

$\mathrm{R}_{\mathrm{f}} 0.18$ (Hex/EtOAc 4/1); ${ }^{1} \mathrm{H}$ NMR (400 MHz, DMSO) $\delta 12.46$ (br s, $1 \mathrm{H}, \mathrm{NH}$ ), 8.47 (m, $2 \mathrm{H}$, Nosyl CH), 8.19 (m, 2 H, Nosyl CH), 5.71 (ddt, $1 \mathrm{H}, J=16.8,10.3,6.4 \mathrm{~Hz}, \mathrm{CH}=\mathrm{CH}_{2}$ ), 5.11$4.81\left(\mathrm{~m}, 2 \mathrm{H}, \mathrm{CH}=\mathrm{CH}_{2}\right), 2.38\left(\mathrm{t}, 2 \mathrm{H}, J=7.2 \mathrm{~Hz}, \mathrm{COCH}_{2} \mathrm{CH}_{2}\right), 2.19(\mathrm{q}, 2 \mathrm{H}, J=6.8 \mathrm{~Hz}$, $\left.\mathrm{COCH}_{2} \mathrm{CH}_{2}\right) ;{ }^{13} \mathrm{C}$ NMR (101 MHz, DMSO) $\delta 172.2,151.2,145.5,137.5,130.1,125.4$, 116.5, 35.4, 28.7; IR 3436 (s), 2959 (m), 2941 (m), 2866 (m), 2143 (w), $1717(\mathrm{w}), 1666$ (w), $1646(\mathrm{w}), 1610(\mathrm{w}), 1535(\mathrm{~m}), 1462(\mathrm{w}), 1449(\mathrm{w}), 1436(\mathrm{w}), 1354(\mathrm{~m}), 1315(\mathrm{w}), 1276(\mathrm{w})$, $1260(\mathrm{w}), 1180(\mathrm{~m}), 1160(\mathrm{w}), 1140(\mathrm{w}), 1114(\mathrm{w}), 1088(\mathrm{~m}), 1018(\mathrm{w}), 998(\mathrm{w}), 922(\mathrm{w})$, $882(\mathrm{~m}), 851(\mathrm{~m}), 832(\mathrm{w}), 815(\mathrm{w}), 804(\mathrm{w}), 794(\mathrm{w}), 781(\mathrm{w}), 767(\mathrm{~m}), 753(\mathrm{~s}), 729(\mathrm{~m})$, $715(\mathrm{w}), 702(\mathrm{~m}), 683(\mathrm{~m}), 671(\mathrm{w}), 662(\mathrm{w}), 647(\mathrm{~m}), 626(\mathrm{w}), 615(\mathrm{~m})$; Melting point: 148.2 ${ }^{\circ} \mathrm{C}$; HRMS (ESI) calcd for $\mathrm{C}_{11} \mathrm{H}_{13} \mathrm{~N}_{2} \mathrm{O}_{5} \mathrm{~S}^{+}\left(\mathrm{M}+\mathrm{H}^{+}\right)$285.0545; found: 285.0577 .

\section{2,2-Dimethyl- $N$-tosylpent-4-enamide (1d)}

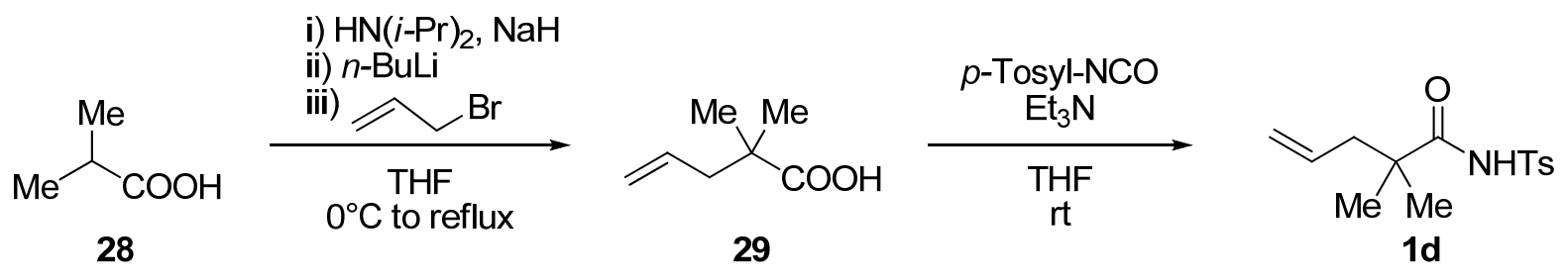

Following a modification of a reported procedure, ${ }^{[9]}$ isobutyric acid (28) $(950 \mathrm{mg}, 10.8 \mathrm{mmol}$, 1.0 equiv) was added dropwise to a stirred suspension of $\mathrm{NaH}(60 \%$ dispersion in mineral oil, $483 \mathrm{mg}, 12.1 \mathrm{mmol}, 1.12$ equiv) and diisopropylamine (1.7 mL, $12 \mathrm{mmol}, 1.1$ equiv) in THF $(20 \mathrm{~mL})$. The resulting suspension was heated at reflux for ca $1 \mathrm{~h}$ and then cooled to $0^{\circ} \mathrm{C}$ for $15 \mathrm{~min}$ prior to the dropwise addition of $n$-BuLi $(2.5 \mathrm{M}$ in hexanes, $7.5 \mathrm{~mL}, 12 \mathrm{mmol}, 1.1$ equiv). The resulting greenish suspension was stirred at $0^{\circ} \mathrm{C}$ for an additional $15 \mathrm{~min}$ and then at room temperature for $2 \mathrm{~h}$. It was then cooled to $0^{\circ} \mathrm{C}$ and allyl bromide $(0.95 \mathrm{~mL}, 11$ mmol, 1.0 equiv) was added dropwise to give an off-white suspension which was stirred at $0^{\circ} \mathrm{C}$ for $1 \mathrm{~h}$ and then at room temperature overnight. The suspension was then cooled with an ice-bath and the excess of $\mathrm{NaH}$ was neutralized with water $(20 \mathrm{~mL})$. The organic layer was washed with a $1 \mathrm{M} \mathrm{NaOH}$ solution $(3 \mathrm{x} 40 \mathrm{~mL})$ and the combined aqueous layers were then extracted with $\mathrm{Et}_{2} \mathrm{O}(40 \mathrm{~mL})$. The aqueous layer was acidified by addition of a $1 \mathrm{M} \mathrm{HCl}$ solution until $\mathrm{pH} 3$ and it was then extracted with ether $(3 \times 40 \mathrm{~mL})$. The combined organic layers were dried over $\mathrm{MgSO}_{4}$, filtered and the solvent was evaporated in vacuo. The crude product was purified by column chromatography $\left(\mathrm{SiO}_{2}, \mathrm{PET} / \mathrm{EtOAc} / \mathrm{AcOH}\right.$ 95/5/0.1) to afford 2,2-dimethylpent-4-enoic acid (29) (379 mg, $3.00 \mathrm{mmol}, 27 \%$ ).

${ }^{1} \mathrm{H}$ NMR (400 MHz, $\left.\mathrm{CDCl}_{3}\right) \delta 8.80$ (br s, $\left.1 \mathrm{H}, \mathrm{COOH}\right), 5.77\left(\mathrm{~m}, 1 \mathrm{H}, \mathrm{CH}=\mathrm{CH}_{2}\right), 5.10$ (m, 1 $\left.\mathrm{H}, \mathrm{CH}=\mathrm{CH}_{2}\right), 5.06\left(\mathrm{~m}, 1 \mathrm{H}, \mathrm{CH}=\mathrm{CH}_{2}\right), 2.31\left(\mathrm{dt}, 2 \mathrm{H}, J=7.4,1.0 \mathrm{~Hz}, \mathrm{CH}_{2} \mathrm{CH}=\mathrm{CH}_{2}\right), 1.20(\mathrm{~s}, 6$ $\left.\mathrm{H}, \mathrm{C}\left(\mathrm{CH}_{3}\right)_{2}\right)$.

[9] D. E. Korte, L. S. Hegedus, R. K. Wirth, J. Org. Chem. 1977, 42, 1329. 
Following a reported procedure, ${ }^{[7]} p$-tosyl isocyanate $(584 \mathrm{mg}, 3.00 \mathrm{mmol}, 1.00$ equiv) was added to a solution of 2,2-dimethylpent-4-enoic acid (29) (379 mg, $3.00 \mathrm{mmol}, 1.00$ equiv) in THF $(8.5 \mathrm{~mL})$. After stirring the resulting clear solution at room temperature for $10 \mathrm{~min}$, triethyl amine $(0.41 \mathrm{~mL}, 3.0 \mathrm{mmol}, 1.00$ equiv) was added dropwise, with release of gas. After $1 \mathrm{~h}$, the mixture was diluted with EtOAc $(8.5 \mathrm{~mL})$ and washed with $2 \mathrm{M} \mathrm{HCl}(8.5 \mathrm{~mL})$ and $\mathrm{NaCl}$ (saturated solution, $8.5 \mathrm{~mL}$ ). The organic layer was dried over $\mathrm{MgSO}_{4}$, filtered and concentrated in vacuo. No further purification was needed. 2,2-Dimethyl- $N$-tosylpent-4enamide (1d) was obtained as a colorless solid ( $826 \mathrm{mg}, 2.90 \mathrm{mmol}, 99 \%$ yield).

$\mathrm{R}_{\mathrm{f}} 0.53$ (Pet/EtOAc 4/1); ${ }^{1} \mathrm{H}$ NMR (400 MHz, $\left.\mathrm{CDCl}_{3}\right) \delta 8.28(\mathrm{~s}, 1 \mathrm{H}, \mathrm{NH}), 7.93(\mathrm{~m}, 2 \mathrm{H}$, tosyl $\mathrm{CH}), 7.33(\mathrm{~m}, 2 \mathrm{H}$, tosyl $\mathrm{CH}), 5.54\left(\mathrm{~m}, 1 \mathrm{H}, \mathrm{CH}=\mathrm{CH}_{2}\right), 5.06-4.92\left(\mathrm{~m}, 2 \mathrm{H}, \mathrm{CH}=\mathrm{CH}_{2}\right)$, $2.45\left(\mathrm{~s}, 3 \mathrm{H}\right.$, tosyl $\left.\mathrm{CH}_{3}\right), 2.23-2.14\left(\mathrm{~m}, 2 \mathrm{H}, \mathrm{CH}_{2} \mathrm{CH}=\mathrm{CH}_{2}\right), 1.13\left(\mathrm{~s}, 6 \mathrm{H}, \mathrm{C}\left(\mathrm{CH}_{3}\right)_{2}\right) ;{ }^{13} \mathrm{C} \mathrm{NMR}$ $\left(101 \mathrm{MHz}, \mathrm{CDCl}_{3}\right) \delta 175.2,145.0,135.4,132.7,129.5,128.4,119.0,44.3,43.4,24.3,21.6$; IR 3552 (w), 3384 (w), 3264 (m), 3132 (w), 3122 (w), 3112 (w), $3111(w), 3078$ (w), 2979 (w), 2931 (w), 2877 (w), 2363 (w), 1714 (m), 1641 (w), 1597 (w), 1469 (m), 1409 (s), 1339 (s), $1294(\mathrm{w}), 1168(\mathrm{~s}), 1114(\mathrm{~m}), 1082$ (s), $1016(\mathrm{w}), 999$ (w), 912 (m), 860 (m), 812 (m), $759(\mathrm{w}), 735(\mathrm{~m}), 704(\mathrm{w}), 661(\mathrm{~s}), 639$ (s), $623(\mathrm{w})$; Melting point: $144.8-148.0^{\circ} \mathrm{C}$; HRMS (ESI) calcd for $\mathrm{C}_{14} \mathrm{H}_{20} \mathrm{NO}_{3} \mathrm{~S}^{+}\left(\mathrm{M}+\mathrm{H}^{+}\right)$282.1164; found: 282.1163 .

\section{1-Allyl- $N$-tosylcyclohexanecarboxamide (1e)}

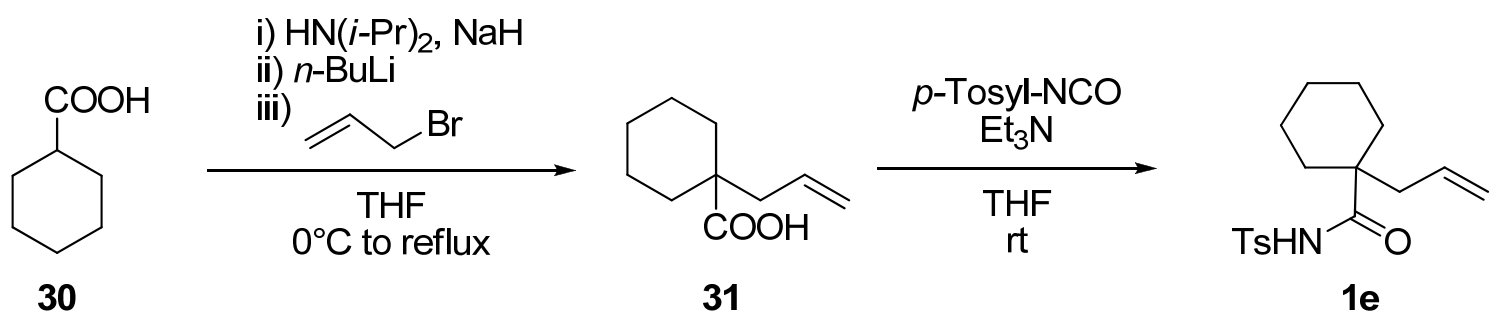

Following a reported procedure ${ }^{[10]} n$-BuLi (2.5 M in hexanes) (10 mL, $25 \mathrm{mmol}, 2.5$ equiv) was added dropwise to a solution of diisopropylamine (2.53 g, $25.0 \mathrm{mmol}, 2.50$ equiv) in THF $(15 \mathrm{~mL})$ at $-78^{\circ} \mathrm{C}$. The mixture was allowed to warm to $0^{\circ} \mathrm{C}$ and stirred at this temperature for $20 \mathrm{~min}$. A solution of cyclohexanecarboxylic acid (30) (1.28 g, $10.0 \mathrm{mmol}$, 1.00 equiv) in THF $(10 \mathrm{~mL})$ was added dropwise to the resulting LDA solution still at $0^{\circ} \mathrm{C}$. The mixture was stirred at room temperature for $40 \mathrm{~min}$ and then at reflux for $50 \mathrm{~min}$. It was then cooled to $0^{\circ} \mathrm{C}$ and allyl bromide $(3.02 \mathrm{~g}, 25.0 \mathrm{mmol}, 2.50$ equiv) was added dropwise. The resulting pale yellow solution was stirred overnight at room temperature. The reaction was quenched by adding $\mathrm{NH}_{4} \mathrm{Cl}$ (saturated solution, $50 \mathrm{~mL}$ ). The aqueous layer was separated from the organic, acidified with $2 \mathrm{M} \mathrm{HCl}(\mathrm{ca} .25 \mathrm{~mL})$ and extracted with $\mathrm{Et}_{2} \mathrm{O}(3 \mathrm{x}$ $50 \mathrm{~mL})$. The combined ethereal layers were washed with $\mathrm{K}_{2} \mathrm{CO}_{3}(20 \% \mathrm{~m} / \mathrm{m}$ solution, $3 \times 50$ $\mathrm{mL}$ ). The combined resulting aqueous layers were acidified to $\mathrm{pH} 3$ with $6 \mathrm{~N} \mathrm{H}_{2} \mathrm{SO}_{4}$ and extracted with $\mathrm{Et}_{2} \mathrm{O}(3 \times 50 \mathrm{~mL})$. The combined organic layers were dried over $\mathrm{MgSO}_{4}$, filtered and concentrated in vacuo. Purification by column chromatography $\left(\mathrm{SiO}_{2}\right.$, DCM/EtOAc/AcOH 95/5/0 to 90/10/0.5) afforded 1-allylcyclohexanecarboxylic acid (31) (1.48 g, $8.79 \mathrm{mmol}, 88 \%$ yield) as a colorless oil.

[10] R. D. Miller, P. Goelitz, J. Org. Chem., 1981, 46, 1616. 
${ }^{1} \mathrm{H}$ NMR (400 MHz, $\mathrm{CDCl}_{3}$ ) $\delta 11.33$ (br s, $1 \mathrm{H}, \mathrm{COOH}$ ), $5.75\left(\mathrm{~m}, 1 \mathrm{H}, \mathrm{CH}_{2} \mathrm{CH}=\mathrm{CH}_{2}\right.$ ), 5.09$5.00\left(\mathrm{~m}, 2 \mathrm{H}, \mathrm{CH}_{2} \mathrm{CH}=\mathrm{CH}_{2}\right), 2.29\left(\mathrm{~d}, 2 \mathrm{H}, J=7.5 \mathrm{~Hz}, \mathrm{CH}_{2} \mathrm{CH}=\mathrm{CH}_{2}\right), 2.04\left(\mathrm{~m}, 2 \mathrm{H}, \mathrm{C}\left(\mathrm{CH}_{2}\right)_{2}\right)$, $1.58\left(\mathrm{~m}, 2 \mathrm{H}, \mathrm{C}\left(\mathrm{CH}_{2}\right)_{2}\right), 1.42\left(\mathrm{~m}, 2 \mathrm{H}, \mathrm{CH}_{2} \mathrm{CH}_{2} \mathrm{CH}_{2}\right), 1.33-1.17$ (m, $4 \mathrm{H}, \mathrm{CH}_{2} \mathrm{CH}_{2} \mathrm{CH}_{2}$ ).

Following a reported procedure, ${ }^{[7]} p$-tosyl isocyanate $(690 \mathrm{mg}, 3.49 \mathrm{mmol}, 1.00$ equiv) was added to a solution of 1-allylcyclohexanecarboxylic acid (31) $(589 \mathrm{mg}, 3.50 \mathrm{mmol}, 1.00$ equiv) in THF $(10 \mathrm{~mL})$. After stirring the resulting clear solution at room temperature for 10 min, triethylamine $(0.49 \mathrm{~mL}, 3.5 \mathrm{mmol}, 1.0$ equiv) was added dropwise, with release of gas. After $1 \mathrm{~h}$, the mixture was diluted with EtOAc $(10 \mathrm{~mL})$ and washed with $2 \mathrm{M} \mathrm{HCl}(10 \mathrm{~mL})$ and $\mathrm{NaCl}$ (saturated solution, $10 \mathrm{~mL}$ ). The organic layer was dried over $\mathrm{MgSO}_{4}$, filtered and concentrated in vacuo. Purification by column chromatography $\left(\mathrm{SiO}_{2}, \mathrm{DCM}\right)$ afforded 1allyl- $N$-tosylcyclohexanecarboxamide (1e) $(778 \mathrm{mg}, 2.42 \mathrm{mmol}, 69 \%$ yield) as a colorless solid.

$\mathrm{R}_{\mathrm{f}} 0.44$ (PET/EtOAc 4/1); ${ }^{1} \mathrm{H}$ NMR (400 MHz, $\left.\mathrm{CDCl}_{3}\right) \delta 8.10$ (br s, $\left.1 \mathrm{H}, \mathrm{NH}\right), 7.93(\mathrm{~m}, 2 \mathrm{H}$, tosyl $\mathrm{CH}), 7.33(\mathrm{~m}, 2 \mathrm{H}$, tosyl $\mathrm{CH}), 5.46\left(\mathrm{~m}, 1 \mathrm{H}, \mathrm{CH}=\mathrm{CH}_{2}\right), 5.00-4.82\left(\mathrm{~m}, 2 \mathrm{H}, \mathrm{CH}=\mathrm{CH}_{2}\right)$, $2.44\left(\mathrm{~s}, 3 \mathrm{H}\right.$, tosyl $\left.\mathrm{CH}_{3}\right), 2.13\left(\mathrm{~d}, 2 \mathrm{H}, J=7.5 \mathrm{~Hz}, \mathrm{CH}_{2} \mathrm{CH}=\mathrm{CH}_{2}\right), 1.85\left(\mathrm{~m}, 2 \mathrm{H}, \mathrm{CH}_{2}\right.$ cyclohexane), 1.62-1.45 (m, $4 \mathrm{H}, \mathrm{CH}_{2}$ cyclohexane), 1.29 (m, $4 \mathrm{H}, \mathrm{CH}_{2}$ cyclohexane); ${ }^{13} \mathrm{C}$ NMR (101 MHz, $\left.\mathrm{CDCl}_{3}\right) \delta 174.0,144.9,135.6,131.9,129.4,128.5,118.9,47.9,43.8,33.4$, 25.5, 22.6, 21.7; IR 3276 (w), 2939 (w), 2867 (w), 1717 (m), $1596(\mathrm{w}), 1493(\mathrm{w}), 1457$ (w), 1442 (m), 1408 (s), 1344 (s), 1310 (w), 1294 (w), 1168 (s), 1151 (m), 1105 (m), 1086 (s), 1070 (s), $1025(\mathrm{w}), 1000(\mathrm{w}), 961(\mathrm{w}), 921(\mathrm{~m}), 906(\mathrm{~m}), 865(\mathrm{~m}), 837(\mathrm{~m}), 820(\mathrm{~m}), 782$ $(\mathrm{m}), 737(\mathrm{~m}), 706(\mathrm{~m}), 670(\mathrm{~s}), 651(\mathrm{~m}), 628(\mathrm{~m}), 611(\mathrm{~m})$; Melting point: $153.4-157.0^{\circ} \mathrm{C}$; HRMS (ESI) calcd for $\mathrm{C}_{17} \mathrm{H}_{24} \mathrm{NO}_{3} \mathrm{~S}^{+}\left(\mathrm{M}+\mathrm{H}^{+}\right)$322.1477; found: 322.1473 .

\section{1-Allyl- $N$-tosylcyclopentanecarboxamide (1f)}

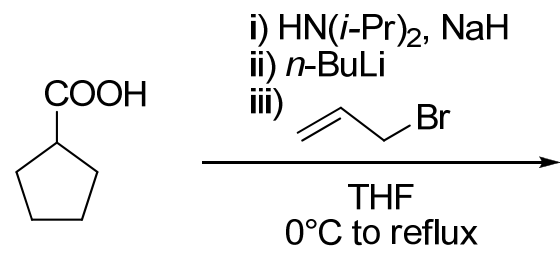

32

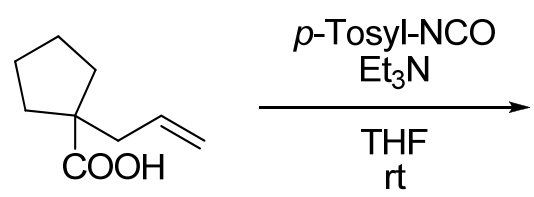

33

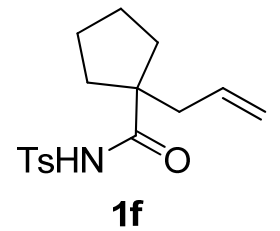

$1 f$

Following a reported procedure, ${ }^{[10]} n$-BuLi (2.5 $\mathrm{M}$ in hexanes) $(8.0 \mathrm{~mL}, 20 \mathrm{mmol}, 2.5$ equiv) was added dropwise to a solution of diisopropylamine $(2.03 \mathrm{~g}, 20.0 \mathrm{mmol}, 2.5$ equiv) in THF $(12 \mathrm{~mL})$ at $-78^{\circ} \mathrm{C}$. The mixture was allowed to warm to $0^{\circ} \mathrm{C}$ and stirred at this temperature for $20 \mathrm{~min}$. A solution of cyclopentanecarboxylic acid (32) $(0.91 \mathrm{~g}, 8.0 \mathrm{mmol}, 1.0$ equiv) in THF $(4 \mathrm{~mL})$ was added dropwise to the resulting LDA solution still at $0^{\circ} \mathrm{C}$. The mixture was stirred at room temperature for $1 \mathrm{~h}$ and then at reflux for $40 \mathrm{~min}$. It was then cooled to $0^{\circ} \mathrm{C}$ and allyl bromide (2.40 g, $19.8 \mathrm{mmol}, 2.50$ equiv) was added dropwise. The resulting clear solution was stirred overnight at $\mathrm{rt}$. The reaction was quenched by adding $\mathrm{NH}_{4} \mathrm{Cl}$ (saturated solution, $40 \mathrm{~mL}$ ). The aqueous layer was separated from the organic, acidified with $2 \mathrm{M} \mathrm{HCl}$ (ca. $20 \mathrm{~mL})$ and extracted with $\mathrm{Et}_{2} \mathrm{O}(3 \mathrm{x} 40 \mathrm{~mL})$. The combined etheral layers were washed with $\mathrm{K}_{2} \mathrm{CO}_{3}(20 \% \mathrm{~m} / \mathrm{m}$ solution, $3 \times 40 \mathrm{~mL})$. The combined resulting aqueous layers were acidified to $\mathrm{pH} 3$ with $6 \mathrm{~N} \mathrm{H}_{2} \mathrm{SO}_{4}$ and extracted with $\mathrm{Et}_{2} \mathrm{O}(3 \times 40 \mathrm{~mL})$. The combined organic layers were dried over $\mathrm{MgSO}_{4}$, filtered and concentrated in vacuo. Purification by 
column chromatography $\left(\mathrm{SiO}_{2}, \mathrm{DCM} / \mathrm{EtOAc} / \mathrm{AcOH} 100 / 0 / 1\right.$ to $\left.90 / 10 / 1\right)$ afforded 1 allylcyclopentanecarboxylic acid (33) (660 mg, $4.28 \mathrm{mmol}, 53 \%$ yield) as a colorless oil.

${ }^{1} \mathrm{H}$ NMR (400 MHz, $\mathrm{CDCl}_{3}$ ) $\delta 11.24$ (br s, $\left.1 \mathrm{H}, \mathrm{COOH}\right), 5.77\left(\mathrm{~m}, 1 \mathrm{H}, \mathrm{CH}_{2} \mathrm{CH}=\mathrm{CH}_{2}\right.$ ), 5.15$5.00\left(\mathrm{~m}, 2 \mathrm{H}, \mathrm{CH}_{2} \mathrm{CH}=\mathrm{CH}_{2}\right), 2.38\left(\mathrm{~d}, 2 \mathrm{H}, J=7.3 \mathrm{~Hz}, \mathrm{CH}_{2} \mathrm{CH}=\mathrm{CH}_{2}\right), 2.11\left(\mathrm{~m}, 2 \mathrm{H}, \mathrm{C}\left(\mathrm{CH}_{2}\right)_{2}\right)$, 1.79-1.48 (m, $6 \mathrm{H}$, cyclopentyl).

Following a reported procedure, ${ }^{[7]} p$-tosyl isocyanate $(848 \mathrm{mg}, 4.30 \mathrm{mmol}, 1.00$ equiv) was added to a solution of 1-allylcyclopentanecarboxylic acid (33) $(650 \mathrm{mg}, 4.28 \mathrm{mmol}, 1.00$ equiv) in THF (12 mL). After stirring the resulting clear solution at room temperature for 10 min, triethylamine $(0.60 \mathrm{~mL}, 4.3 \mathrm{mmol}, 1.0$ equiv) was added dropwise, with release of gas. After $1 \mathrm{~h}$, the mixture was diluted with EtOAc $(12 \mathrm{~mL})$ and washed with $2 \mathrm{M} \mathrm{HCl}(12 \mathrm{~mL})$ and $\mathrm{NaCl}$ (saturated solution, $12 \mathrm{~mL}$ ). The organic layer was dried over $\mathrm{MgSO}_{4}$, filtered and concentrated in vacuo. Purification by column chromatography $\left(\mathrm{SiO}_{2}, \mathrm{DCM} / \mathrm{AcOH} 100 / 0.5\right)$ afforded 1-allyl- $N$-tosylcyclopentanecarboxamide (1f) $(1.00 \mathrm{~g}, 3.24 \mathrm{mmol}, 76 \%$ yield) as a colorless solid.

$\mathrm{R}_{\mathrm{f}} 0.47$ (PET/EtOAc 4/1); ${ }^{1} \mathrm{H}$ NMR (400 MHz, $\left.\mathrm{CDCl}_{3}\right) \delta 8.30$ (br s, $\left.1 \mathrm{H}, \mathrm{NH}\right), 7.93(\mathrm{~m}, 2 \mathrm{H}$, tosyl $\mathrm{CH}), 7.33(\mathrm{~m}, 2 \mathrm{H}$, tosyl $\mathrm{CH}), 5.50\left(\mathrm{~m}, 1 \mathrm{H}, \mathrm{CH}_{2} \mathrm{CH}=\mathrm{CH}_{2}\right), 5.01-4.88(\mathrm{~m}, 2 \mathrm{H}$, $\left.\mathrm{CH}_{2} \mathrm{CH}=\mathrm{CH}_{2}\right), 2.44\left(\mathrm{~s}, 3 \mathrm{H}\right.$, tosyl $\left.\mathrm{CH}_{3}\right), 2.25\left(\mathrm{~d}, 2 \mathrm{H}, \mathrm{J}=7.3 \mathrm{~Hz}, \mathrm{CH}_{2} \mathrm{CH}=\mathrm{CH}_{2}\right), 1.97(\mathrm{~m}, 2$ $\mathrm{H}$, cyclopentyl), $1.68-1.48$ (m, $6 \mathrm{H}$, cyclopentyl); ${ }^{13} \mathrm{C} \mathrm{NMR}\left(101 \mathrm{MHz}, \mathrm{CDCl}_{3}\right) \delta 174.7$, 144.9, 135.5, 133.1, 129.4, 128.4, 118.6, 55.1, 42.7, 34.7, 24.5, 21.6; IR 3264 (m), $2956(\mathrm{w})$, 2924 (w), 2873 (w), 1713 (s), 1642 (w), 1596 (w), 1596 (w), 1409 (s), 1342 (s), 1191 (m), 1169 (s), 1117 (m), 1086 (s), 1044 (w), 988 (w), 915 (m), 867 (m), 836 (w), 816 (m), 793 $(\mathrm{w}), 734(\mathrm{~m}), 664(\mathrm{~s}), 628(\mathrm{w}), 605(\mathrm{w})$; Melting point: $117.1-120.2^{\circ} \mathrm{C}$; HRMS (ESI) calcd for $\mathrm{C}_{16} \mathrm{H}_{22} \mathrm{NO}_{3} \mathrm{~S}^{+}\left(\mathrm{M}+\mathrm{H}^{+}\right)$308.1320; found: 308.1312 .

\section{3-Phenyl- $N$-tosylpent-4-enamide (1g)}

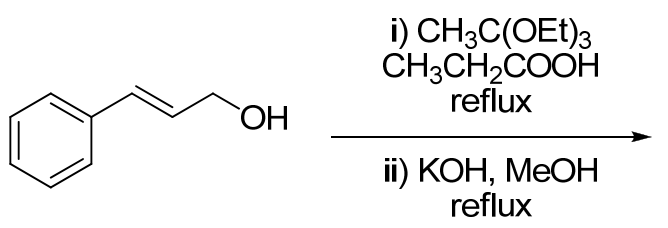

34

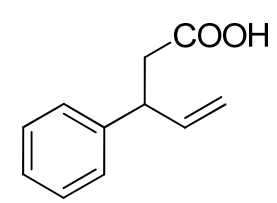

35
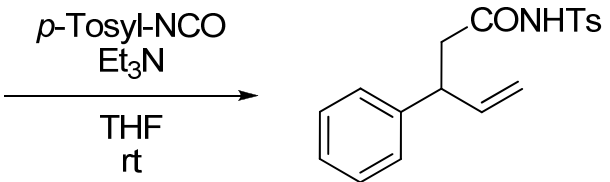

19

Following a modification of a reported procedure, ${ }^{[11]}$ a flask equipped with a Dean-Stark and a condenser was charged with cinnamyl alcohol (34) $(1.9 \mathrm{~mL}, 15 \mathrm{mmol}, 1.0$ equiv), triethylorthoacetate $(14 \mathrm{~mL}, 75 \mathrm{mmol}, 5.0$ equiv) and propionic acid $(7 \mu \mathrm{L}, 0.09 \mathrm{mmol}, 0.06$ equiv). The mixture was heated to reflux for $3 \mathrm{~h}$, while ca $12.5 \mathrm{~mL}$ triethylorthoacetate where distilled away. The resulting pale yellow solution was allowed to cool to room temperature, $\mathrm{MeOH}(15 \mathrm{~mL})$ and $\mathrm{KOH}(2.5 \mathrm{~g}, 45 \mathrm{mmol}, 3.0$ equiv) were added and the mixture was then refluxed for $5 \mathrm{~h}$. $\mathrm{MeOH}$ was then removed under reduced pressure and the crude oil residue was dissolved in $\mathrm{Et}_{2} \mathrm{O}$ (ca $30 \mathrm{~mL}$ ) and extracted with a saturated solution of $\mathrm{NaHCO}_{3}$ (ca 30 $\mathrm{mL})$. The aqueous layer was further washed with $\mathrm{Et}_{2} \mathrm{O}(3 \times 25 \mathrm{~mL})$, acidified with $2 \mathrm{~N} \mathrm{HCl}$ to

[11] W. Li, C. E. Hanau, A. d'Avignon, K. D. Moeller, J. Org. Chem. 1995, 60, 8155. 
pH 1 and extracted with DCM (3 x $25 \mathrm{~mL})$. The combined organic layers were dried over $\mathrm{MgSO}_{4}$, filtered and concentrated in vacuo to afford 3-phenylpent-4-enoic acid (35) (2.14 g, $12.1 \mathrm{mmol}, 81 \%$ yield) as a pale yellow oil, which was used without further purification.

Following a reported procedure, ${ }^{[7]} p$-tosyl isocyanate (394 mg, $1.99 \mathrm{mmol}, 1.00$ equiv) was added to a solution of 3-phenylpent-4-enoic acid (35) (350 mg, $1.99 \mathrm{mmol}, 1.00$ equiv) in THF $(6 \mathrm{~mL})$. After stirring the resulting clear solution at room temperature for $10 \mathrm{~min}$, triethylamine $(0.28 \mathrm{~mL}, 2.0 \mathrm{mmol}, 1.0$ equiv) was added dropwise, with release of gas. After $1 \mathrm{~h}$, the mixture was diluted with EtOAc $(6 \mathrm{~mL})$ and washed with $2 \mathrm{M} \mathrm{HCl}(6 \mathrm{~mL})$ and $\mathrm{NaCl}$ (saturated solution, $6 \mathrm{~mL}$ ). The organic layer was dried over $\mathrm{MgSO}_{4}$, filtered and concentrated in vacuo. Purification by column chromatography $\left(\mathrm{SiO}_{2}, \mathrm{PET} /\right.$ EtOAc 80/20) afforded 3-phenyl- $N$-tosylpent-4-enamide (1g) (660 mg, $2.01 \mathrm{mmol}$, quantitative) as a very viscous, colorless oil.

$\mathrm{R}_{\mathrm{f}} 0.34$ (PET/EtOAc 4/1); ${ }^{1} \mathrm{H}$ NMR (400 MHz, $\left.\mathrm{CDCl}_{3}\right) \delta 8.98$ (br s, $\left.1 \mathrm{H}, \mathrm{NH}\right), 7.81$ (m, $2 \mathrm{H}$, tosyl $\mathrm{CH}$ ), 7.31-7.15 (m, $5 \mathrm{H}, \mathrm{Ph} \mathrm{CH}), 7.07(\mathrm{~m}, 2 \mathrm{H}$, tosyl $\mathrm{CH}), 5.87$ (ddd, $1 \mathrm{H}, J=17.5$, $\left.10.3,7.0 \mathrm{~Hz}, \mathrm{CH}=\mathrm{CH}_{2}\right), 4.98\left(\mathrm{~d}, 1 \mathrm{H}, J=10.3 \mathrm{~Hz}, \mathrm{CH}=\mathrm{CH}_{2}\right), 4.93(\mathrm{~d}, 1 \mathrm{H}, J=17.2 \mathrm{~Hz}$, $\left.\mathrm{CH}=\mathrm{CH}_{2}\right), 3.77(\mathrm{dd}, 1 \mathrm{H}, J=14.8,7.4 \mathrm{~Hz}$, allylic $\mathrm{CH}), 2.69(\mathrm{dd}, 1 \mathrm{H}, J=14.9,7.9 \mathrm{~Hz}$, $\left.\mathrm{COCH}_{2}\right), 2.61\left(\mathrm{dd}, 1 \mathrm{H}, J=14.8,7.4 \mathrm{~Hz}, \mathrm{COCH}_{2}\right), 2.43\left(\mathrm{~s}, 3 \mathrm{H}\right.$, tosyl $\left.\mathrm{CH}_{3}\right) ;{ }^{13} \mathrm{C}$ NMR $(101$ $\left.\mathrm{MHz}, \mathrm{CDCl}_{3}\right) \delta 169.3,144.0,140.5,138.3,134.2,128.5,127.7,127.2,126.3,125.8,114.3$, 44.3, 41.2, 20.6; IR 3595 (w), 3544 (w), 3243 (w), 3087 (w), $2924(w), 2361(w), 2343(w)$, $1698(\mathrm{~m}), 1639$ (w), 1598 (w), 1493 (w), 1441 (s), 1379 (w), 1344 (m), 1308 (w), $1295(\mathrm{w})$, 1189 (m), 1172 (s), 1144 (m), 1121 (w), 1087 (s), 997 (w), 915 (m), 857 (m), 815 (m), 759 (m), $734(\mathrm{~m}), 703(\mathrm{~s}), 683(\mathrm{~m}), 672(\mathrm{~m}), 661$ (s), $646(\mathrm{w}), 611(\mathrm{w})$; HRMS (ESI) calcd for $\mathrm{C}_{18} \mathrm{H}_{20} \mathrm{NO}_{3} \mathrm{~S}^{+}\left(\mathrm{M}+\mathrm{H}^{+}\right)$330.1164; found: 330.1171 .

\section{$N$-Tosyl-2-vinylcyclohexanecarboxamide (1h)}<smiles>O=C1OC(=O)C2CCCCC12</smiles>

36
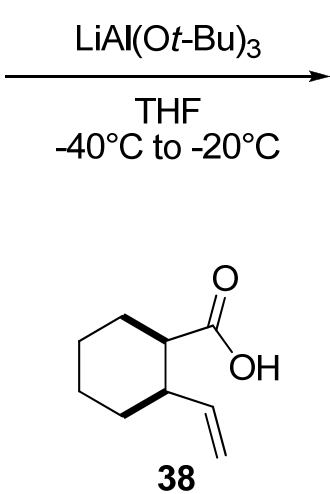<smiles>O=C1O[C@H](O)C2CCCC[C@H]12</smiles>
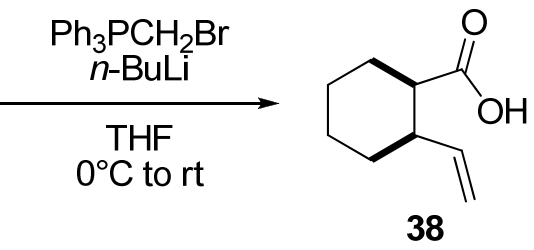

38

Following a modification of a reported procedure, ${ }^{[12]} 1,2$-cyclohexanedicarboxylic anhydride (36) (1.54 g, $9.99 \mathrm{mmol}, 1.00$ equiv) was dissolved in THF (12.5 mL) and the resulting solution was cooled to $-40^{\circ} \mathrm{C}$. $\mathrm{LiAl}(\mathrm{Ot}-\mathrm{Bu})_{3}(3.17 \mathrm{~g}, 12.5 \mathrm{mmol}, 1.25$ equiv $)$ was dissolved in THF $(20 \mathrm{~mL})$ at $-40^{\circ} \mathrm{C}$ and the resulting off-white solution was cannulated into the flask containing the anhydride solution. The mixture was allowed to warm to $-20^{\circ} \mathrm{C}$ over $6 \mathrm{~h}$

[12] P. Canonne, M. Akssira, Tetrahedron 1985, 41, 3695. 
(attention was paid not to go over this temperature). The reaction mixture was then quenched by addition of a $10 \% \mathrm{HCl}$ solution until all solids were dissolved. The aqueous layer was extracted with $\mathrm{Et}_{2} \mathrm{O}(4 \times 30 \mathrm{~mL})$ and the combined organic layers were washed with brine, dried over $\mathrm{MgSO}_{4}$, filtered and concentrated in vacuo. Purification by column chromatography ( $\mathrm{SiO}_{2}, \mathrm{PET} /$ EtOAc 90/10) afforded lactol 37 (629 mg, $4.03 \mathrm{mmol}, 40 \%$ yield) as a colorless, viscous oil.

Following a reported procedure, ${ }^{[13]} n$-BuLi (1.6 M in hexanes) $(5.4 \mathrm{~mL}, 8.6 \mathrm{mmol}, 2.2$ equiv) was added dropwise to a suspension of $\mathrm{Ph}_{3} \mathrm{PCH}_{2} \mathrm{Br}(3.07 \mathrm{~g}, 8.58 \mathrm{mmol}, 2.20$ equiv) in THF $(14 \mathrm{~mL})$ at $0^{\circ} \mathrm{C}$. After $30 \mathrm{~min}$, a solution of lactol $37(610 \mathrm{mg}, 3.91 \mathrm{mmol}, 1.00$ equiv) in THF $(9.2 \mathrm{~mL})$ was cannulated into the ylide solution and the resulting mixture was allowed to warm to room temperature under stirring. The reaction was then quenched by adding a $10 \%$ $\mathrm{NaOH}$ solution until all solids were dissolved. The aqueous layer was washed with EtOAc (3 $\mathrm{x} 40 \mathrm{~mL}$ ). The resulting aqueous solution was acidified with $4 \mathrm{~N} \mathrm{HCl}$ until $\mathrm{pH} 3$ and extracted with EtOAc ( 3 x $40 \mathrm{~mL}$ ). The combined organic layers were dried over $\mathrm{MgSO}_{4}$, filtered and concentrated in vacuo. Purification by column chromatography $\left(\mathrm{SiO}_{2}, \mathrm{PET} / \mathrm{EtOAc} 90 / 10\right)$ afforded 2-vinylcyclohexanecarboxylic acid (38) (266 mg, $1.72 \mathrm{mmol}, 44 \%$ yield) as a yellow oil.

${ }^{1} \mathrm{H}$ NMR (400 MHz, $\mathrm{CDCl}_{3}$ ) $\delta 11.59$ (br s, $1 \mathrm{H}, \mathrm{COOH}$ ), 5.98 (ddd, $1 \mathrm{H}, J=18.3,10.4,8.0$ $\left.\mathrm{Hz}, \mathrm{CHCH}=\mathrm{CH}_{2}\right), 5.15-4.99\left(\mathrm{~m}, 2 \mathrm{H}, \mathrm{CH}=\mathrm{CH}_{2}\right), 2.68\left(\mathrm{~m}, 1 \mathrm{H}, \mathrm{CHCH}=\mathrm{CH}_{2}\right), 2.61(\mathrm{~m}, 1 \mathrm{H}$, CHCOOH), 1.90-1.29 (m, $10 \mathrm{H}$, cyclohexane).

Following a reported procedure, ${ }^{[7]} p$-tosyl isocyanate $(255 \mathrm{mg}, 1.29 \mathrm{mmol}, 1.00$ equiv) was added to a solution of 2-vinylcyclohexanecarboxylic acid $\mathbf{3 8}(200 \mathrm{mg}, 1.30 \mathrm{mmol}, 1.00$ equiv) in THF ( $4 \mathrm{~mL})$. After stirring the resulting clear solution at room temperature for 10 min, triethyl amine $(0.18 \mathrm{~mL}, 1.3 \mathrm{mmol}, 1.0$ equiv) was added dropwise, with release of gas. After $1 \mathrm{~h}$, the mixture was diluted with EtOAc $(4 \mathrm{~mL})$ and washed with $2 \mathrm{M} \mathrm{HCl}(4 \mathrm{~mL})$ and $\mathrm{NaCl}$ (saturated solution, $4 \mathrm{~mL}$ ). The organic layer was dried over $\mathrm{MgSO}_{4}$, filtered and concentrated in vacuo. The resulting crude solid was dissolved in $\mathrm{Et}_{2} \mathrm{O}$ in order to obtain a saturated solution and hexane was added to precipitate the pure tosyl amide. $N$-tosyl-2vinylcyclohexanecarboxamide (1h) was obtained as a colorless solid $(0.18 \mathrm{~g}, 0.59 \mathrm{mmol}$, $45 \%$ yield).

$\mathrm{R}_{\mathrm{f}} 0.54(\mathrm{PET} / \mathrm{EtOAc} 4 / 1) ;{ }^{1} \mathrm{H}$ NMR $\left(400 \mathrm{MHz}, \mathrm{CDCl}_{3}\right) \delta$ 8.09-7.86 (m, $3 \mathrm{H}, \mathrm{NH}$ and tosyl $\mathrm{CH}), 7.31(\mathrm{~m}, 2 \mathrm{H}$, tosyl $\mathrm{CH}), 5.79$ (ddd, $1 \mathrm{H}, \mathrm{J}=17.0,10.5,8.2 \mathrm{~Hz}, \mathrm{CH}=\mathrm{CH}_{2}$ ), 4.96-4.87 $\left(\mathrm{m}, 2 \mathrm{H}, \mathrm{CH}=\mathrm{CH}_{2}\right), 2.51(\mathrm{~m}, 1 \mathrm{H}$, cyclohexane $\mathrm{CH}), 2.47-2.36(\mathrm{~m}, 1 \mathrm{H}, \mathrm{COCHCH}), 2.44(\mathrm{~s}, 3$ $\mathrm{H}$, tosyl $\left.\mathrm{CH}_{3}\right), 1.78-1.22\left(\mathrm{~m}, 10 \mathrm{H}\right.$, cyclohexane $\left.\mathrm{CH}_{2}\right) ;{ }^{13} \mathrm{C} \mathrm{NMR}\left(101 \mathrm{MHz}, \mathrm{CDCl}_{3}\right) \delta 171.7$, $144.9,137.3,135.6,129.4,128.5,116.8,47.5,41.7,30.1,24.5,23.8,21.9,21.7$; IR $3250(\mathrm{w})$, $2934(\mathrm{~m}), 2861(\mathrm{w}), 2348(\mathrm{w}), 2339(\mathrm{w}), 1720(\mathrm{~m}), 1641(\mathrm{w}), 1598(\mathrm{w}), 1492(\mathrm{w}), 1437(\mathrm{~s})$, $1378(\mathrm{w}), 1342$ (m), $1311(\mathrm{w}), 1293(\mathrm{w}), 1277(\mathrm{w}), 1257$ (w), $1174(\mathrm{~s}), 1162$ (s), 1134 (m), $1114(\mathrm{~m}), 1087(\mathrm{~s}), 1058(\mathrm{w}), 1018(\mathrm{w}), 997(\mathrm{w}), 956(\mathrm{w}), 915(\mathrm{~m}), 894(\mathrm{w}), 846(\mathrm{~m}), 816$ (w), 763 (s), 747 (s), 710 (w), 704 (w), 666 (s), 655 (m), 642 (s), 635 (m), 622 (w); Melting point: $123.5-124.5^{\circ} \mathrm{C}$; HRMS (ESI) calcd for $\mathrm{C}_{16} \mathrm{H}_{22} \mathrm{NO}_{3} \mathrm{~S}^{+}\left(\mathrm{M}+\mathrm{H}^{+}\right)$308.1320; found: 308.1307 .

[13] W. H. Moser, L. S. Hegedus, J. Am. Chem. Soc. 1996, 118, 7873. 


\section{$N$-Tosylhex-5-enamide (1i)}

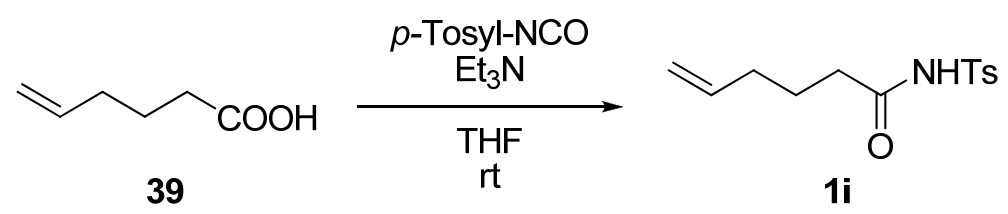

Following a reported procedure, ${ }^{[7]} p$-tosyl isocyanate $(1.19 \mathrm{~g}, 6.05 \mathrm{mmol}, 1.10$ equiv) was added to a solution of 5-hexenoic acid (39) (627 mg, $5.49 \mathrm{mmol}, 1.00$ equiv) in THF (16 $\mathrm{mL})$. After stirring the resulting clear solution at $\mathrm{rt}$ for $10 \mathrm{~min}$, triethylamine $(0.84 \mathrm{~mL}, 6.0$ mmol, 1.1 equiv) was added dropwise, with release of gas. After $1 \mathrm{~h}$, the mixture was diluted with EtOAc $(16 \mathrm{~mL})$ and washed with $2 \mathrm{M} \mathrm{HCl}(16 \mathrm{~mL})$ and $\mathrm{NaCl}$ (saturated solution, 12 $\mathrm{mL}$ ). The organic layer was dried over $\mathrm{MgSO}_{4}$, filtered and concentrated in vacuo. The resulting crude solid was dissolved in $\mathrm{Et}_{2} \mathrm{O}$ in order to obtain a saturated solution and hexane was added to precipitate the pure tosyl amide. $N$-tosylhex-5-enamide (1i) was obtained as a colorless, crystalline solid (1.37 g, $5.14 \mathrm{mmol}, 93 \%$ yield).

$\mathrm{R}_{\mathrm{f}} 0.75\left(\mathrm{DCM} / \mathrm{MeOH}\right.$ 95/5); ${ }^{1} \mathrm{H}$ NMR $\left(400 \mathrm{MHz}, \mathrm{CDCl}_{3}\right) \delta 8.82$ (br s, $\left.1 \mathrm{H}, \mathrm{NH}\right), 7.94$ (m, 2 $\mathrm{H}$, tosyl $\mathrm{CH}),{ }^{[14]} 7.34(\mathrm{~m}, 2 \mathrm{H}$, tosyl $\mathrm{CH}), 5.67$ (ddt, $1 \mathrm{H}, J=17.1,10.5,6.5 \mathrm{~Hz}, C H=\mathrm{CH}_{2}$ ), 5.00-4.87 (m, $\left.2 \mathrm{H}, \mathrm{CH}=\mathrm{CH}_{2}\right), 2.44\left(\mathrm{~s}, 3 \mathrm{H}\right.$, tosyl $\left.\mathrm{CH}_{3}\right), 2.26(\mathrm{t}, 2 \mathrm{H}, J=7.4 \mathrm{~Hz}$, $\mathrm{COCH}_{2} \mathrm{CH}_{2} \mathrm{CH}_{2}$ ), 1.99 (q, $2 \mathrm{H}, J=6.9 \mathrm{~Hz}, \mathrm{COCH}_{2} \mathrm{CH}_{2} \mathrm{CH}_{2}$ ), 1.66 (quint, $2 \mathrm{H}, J=7.4 \mathrm{~Hz}$, $\left.\mathrm{COCH}_{2} \mathrm{CH}_{2} \mathrm{CH}_{2}\right) ;{ }^{13} \mathrm{C}$ NMR $\left(101 \mathrm{MHz}, \mathrm{CDCl}_{3}\right) \delta 170.8,145.2,137.2,135.5,129.6,128.3$, 115.7, 35.3, 32.6, 23.2, 21.7; IR 3591 (w), 3254 (w), $3071(\mathrm{w}), 2936(\mathrm{w}), 2867(\mathrm{w}), 1718$ (m), $1641(\mathrm{w}), 1598(\mathrm{w}), 1494(\mathrm{w}), 1489$ (w), 1440 (s), 1341 (m), 1308 (w), 1294 (w), 1220 (w), 1189 (m), $1171(\mathrm{~s}), 1141(\mathrm{~m}), 1087$ (s), $1020(\mathrm{w}), 996(\mathrm{w}), 916(\mathrm{w}), 871(\mathrm{~m}), 842(\mathrm{~m})$, $816(\mathrm{~m}), 743(\mathrm{w}), 706(\mathrm{w}), 665(\mathrm{~s}), 625(\mathrm{~m}), 614(\mathrm{w}), 606(\mathrm{w})$; Melting point: $71.8-73.5{ }^{\circ} \mathrm{C}$; the reported values for $1 \mathbf{i}$ corresponded to the ones in literature. ${ }^{[15]}$

\section{2-Allyl- $N$-tosylbenzamide (1j)}

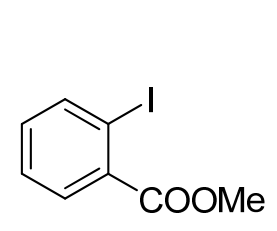

40

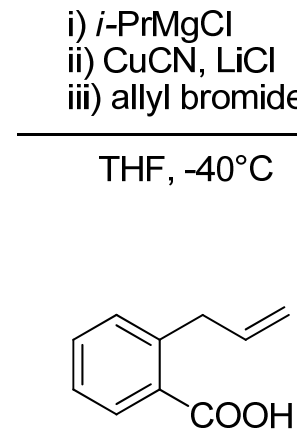

42

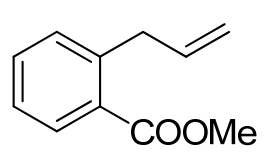

41

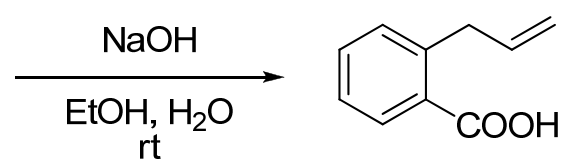

42

Following a reported procedure, ${ }^{[16]} i-\mathrm{PrMgCl}(2.0 \mathrm{M}$ in THF) $(5.25 \mathrm{~mL}, 10.5 \mathrm{mmol}, 1.50$ equiv) was added dropwise to a solution of ethyl 2-iodobenzoate (40) (1.84 g, $7.01 \mathrm{mmol}$, 1.00 equiv) in $\mathrm{THF}(74 \mathrm{~mL})$ at $-40^{\circ} \mathrm{C}$. The resulting mixture was stirred at $-40^{\circ} \mathrm{C}$ for $1.5 \mathrm{~h}$. A

[14] The value for the peak at $7.94 \mathrm{ppm}$ is different from the reported one in the literature $(7.65 \mathrm{ppm}) \mathrm{but}$ corresponds better to what is expected for this proton signal.

[15] L. Wu, S. Qiu, G. Liu. Org. Lett. 2009, 11, 2707.

[16] O. Querolle, J. Dubois, S. Thoret, F. Roussi, F. Guéritte, D. Guénard, J. Med. Chem. 2004, 47 , 5937. 
freshly prepared solution of $\mathrm{CuCN}$ (627 mg, $7.00 \mathrm{mmol}, 1.00$ equiv) and $\mathrm{LiCl}$ (594 mg, 14.0 mmol, 2.0 equiv) in THF (20 mL) was added, followed, after $15 \mathrm{~min}$, by dropwise addition of allyl bromide $\left(2.43 \mathrm{~mL}, 28.0 \mathrm{mmol}, 4.0\right.$ equiv). After being stirred at $-40^{\circ} \mathrm{C}$, the mixture was allowed to warm to rt, diluted with EtOAc $(50 \mathrm{~mL})$ and filtered over celite. The organic solution was washed with a $25 \%$ ammonia aqueous solution $(100 \mathrm{~mL})$. The aqueous layer was extracted with EtOAc $(2 \times 100 \mathrm{~mL})$. The combined organic layers were washed with brine $(1 \times 100 \mathrm{~mL})$, dried over $\mathrm{MgSO}_{4}$, filtered and concentrated in vacuo. The crude product was subjected to a short chromatography column $\left(\mathrm{SiO}_{2}, \mathrm{PET} / \mathrm{EtOAc} 90 / 10\right)$ and dissolved in EtOH $(100 \mathrm{~mL}) .2 \mathrm{~N} \mathrm{NaOH}(75 \mathrm{~mL})$ was added and the resulting mixture was stirred at room temperature for $4 \mathrm{~h}$. EtOH was then removed under reduced pressure and the aqueous layer was extracted with $\mathrm{Et}_{2} \mathrm{O}(2 \times 75 \mathrm{~mL})$; it was then acidified to $\mathrm{pH} 3$ with $2 \mathrm{~N} \mathrm{HCl}$ and extracted with EtOAc $(3 \times 75 \mathrm{~mL})$. The combined organic layers were dried over $\mathrm{MgSO}_{4}$, filtered and concentrated in vacuo to afford 2-allyl benzoic acid (42) (1.07 g, $6.58 \mathrm{mmol}$, $94 \%$ yield over two steps) as a colorless solid which did not require further purification.

${ }^{1} \mathrm{H}$ NMR (400 MHz, $\mathrm{CDCl}_{3}$ ) $\delta 11.64$ (br s, $\left.1 \mathrm{H}, \mathrm{COOH}\right), 8.06$ (dd, $1 \mathrm{H}, J=8.3,1.6 \mathrm{~Hz}, \mathrm{Ar} H$ ), $7.51(\mathrm{~m}, 1 \mathrm{H}, \operatorname{Ar} H), 7.32(\mathrm{~m}, 2 \mathrm{H}, \operatorname{Ar} H), 6.05(\mathrm{ddt}, 1 \mathrm{H}, J=17.0,10.5,6.5 \mathrm{~Hz}$, $\left.\mathrm{CH}_{2} \mathrm{CH}=\mathrm{CH}_{2}\right), 5.07\left(\mathrm{~m}, 1 \mathrm{H}, \mathrm{CH}_{2} \mathrm{CH}=\mathrm{CH}_{2}\right), 5.04\left(\mathrm{~m}, 1 \mathrm{H}, \mathrm{CH}_{2} \mathrm{CH}=\mathrm{CH}_{2}\right), 3.84(\mathrm{~d}, 2 \mathrm{H}, \mathrm{J}=$ $6.5 \mathrm{~Hz}, \mathrm{CH}_{2} \mathrm{CH}=\mathrm{CH}_{2}$ ).

Following a reported procedure, ${ }^{[7]} p$-tosyl isocyanate $(690 \mathrm{mg}, 3.50 \mathrm{mmol}, 1.00$ equiv) was added to a solution of 2-allyl benzoic acid 42 (567 mg, $3.50 \mathrm{mmol}, 1.00$ equiv) in THF (10 $\mathrm{mL}$ ). After stirring the resulting clear solution at room temperature for $10 \mathrm{~min}$, triethylamine (0.49 mL, $3.5 \mathrm{mmol}, 1.0$ equiv) was added dropwise, with release of gas. After $1 \mathrm{~h}$, the mixture was diluted with EtOAc $(10 \mathrm{~mL})$ and washed with $2 \mathrm{M} \mathrm{HCl}(10 \mathrm{~mL})$ and $\mathrm{NaCl}$ (saturated solution, $10 \mathrm{~mL}$ ). The organic layer was dried over $\mathrm{MgSO}_{4}$, filtered and concentrated in vacuo. Purification by column chromatography $\left(\mathrm{SiO}_{2}, \mathrm{DCM} / \mathrm{EtOAc} 90 / 10\right)$ afforded 2-allyl- $N$-tosylbenzamide (1j) (972 mg, $3.08 \mathrm{mmol}, 88 \%$ yield) as a colorless solid.

$\mathrm{R}_{\mathrm{f}} 0.51\left(\mathrm{PET} /\right.$ EtOAc 4/1); ${ }^{1} \mathrm{H}$ NMR $\left(400 \mathrm{MHz}, \mathrm{CDCl}_{3}\right) \delta 8.49(\mathrm{~s}, 1 \mathrm{H}, \mathrm{NH}), 8.04(\mathrm{~m}, 2 \mathrm{H}$, tosyl $\mathrm{CH}), 7.52-7.35(\mathrm{~m}, 4 \mathrm{H}, A r$ and tosyl $\mathrm{CH}), 7.27(\mathrm{~m}, 2 \mathrm{H}, A r H), 5.88(\mathrm{~m}, 1 \mathrm{H}$, $\left.\mathrm{CH}=\mathrm{CH}_{2}\right), 4.99\left(\mathrm{dd}, 1 \mathrm{H}, J=10.1,1.4 \mathrm{~Hz}, \mathrm{CH}=\mathrm{CH}_{2}\right), 4.85(\mathrm{dq}, 1 \mathrm{H}, J=17.1,2.0 \mathrm{~Hz}$, $\left.\mathrm{CH}=\mathrm{CH}_{2}\right), 3.47\left(\mathrm{~d}, 2 \mathrm{H}, \mathrm{J}=6.2 \mathrm{~Hz}, \mathrm{CH}_{2} \mathrm{CH}=\mathrm{CH}_{2}\right), 2.48\left(\mathrm{~s}, 3 \mathrm{H}\right.$, tosyl $\left.\mathrm{CH}_{3}\right) ;{ }^{13} \mathrm{C}$ NMR $(101$ $\left.\mathrm{MHz}_{1} \mathrm{CDCl}_{3}\right) \delta 166.1,145.2,138.9,137.0,135.5,132.7,132.0,131.2,129.6,128.7,127.9$, 126.7, 116.7, 37.3, 21.7; IR $3246(\mathrm{w}), 3235(\mathrm{w}), 3211(\mathrm{w}), 1699(\mathrm{~m}), 1640(\mathrm{w}), 1598(\mathrm{w})$, 1598 (w), 1491 (w), 1429 (m), 1347 (m), 1309 (w), 1309 (w), 1293 (w), 1293 (w), 1245 (w), 1168 (s), 1129 (w), 1129 (w), 1088 (w), 1060 (m), 996 (w), $955(\mathrm{w}), 912(\mathrm{w}), 894(\mathrm{w}), 847$ (m), $813(\mathrm{w}), 778(\mathrm{w}), 778(\mathrm{w}), 746(\mathrm{w}), 687(\mathrm{w}), 679(\mathrm{w}), 661(\mathrm{~m}), 641(\mathrm{w}), 641(\mathrm{w}), 630$ (w); Melting point: $92.3-93.7^{\circ} \mathrm{C}$; HRMS (ESI) calcd for $\mathrm{C}_{17} \mathrm{H}_{18} \mathrm{NO}_{3} \mathrm{~S}^{+}\left(\mathrm{M}+\mathrm{H}^{+}\right)$316.1007; found: 316.0993 .

1-Allyl- $N$-tosyl-1H-pyrrole-2-carboxamide (1k) 
<smiles>O=C(O)c1ccc[nH]1</smiles>

43<smiles>C=CCn1cccc1C(=O)OCC</smiles>

45

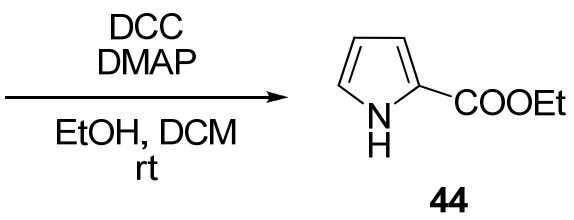

44

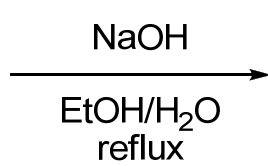

reflux<smiles>C=CCn1cccc1C(=O)O</smiles>

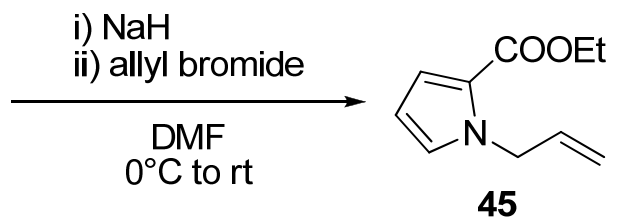

EDCI-HCl

DMAP

46

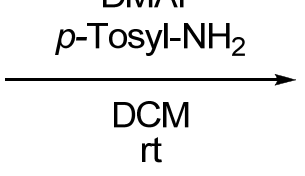

$\mathrm{rt}$

Following a reported procedure, ${ }^{[17]}$ DCC (1.15 g, $5.58 \mathrm{mmol}, 1.12$ equiv) was dissolved in DCM (3.0 mL) and the resulting solution was cannulated into a suspension of pyrrole-2carboxylic acid (43) (555 mg, $4.99 \mathrm{mmol}, 1.00$ equiv) in EtOH (7.5 mL). DMAP (30.5 mg, 0.249 mmol, 0.05 equiv) was added to the colorless mixture, which was stirred overnight at room temperature. The solvents were then evaporated under reduced pressure and the crude product was purified by column chromatography (PET/EtOAc $95 / 5$ to $85 / 15$ ) to afford ethyl pyrrole-2-carboxylate (44) (647 mg, $4.65 \mathrm{mmol}, 93 \%$ yield) as a colorless solid).

Ethyl pyrrole-2-carboxylate 44 (647 mg, $4.65 \mathrm{mmol}, 1.0$ equiv) was dissolved in DMF (1 $\mathrm{mL})$ and the resulting solution was added dropwise to a suspension of $\mathrm{NaH}(60 \%$ in mineral oil) (170 mg, $6.94 \mathrm{mmol}, 1.5$ equiv) in DMF $(5 \mathrm{~mL})$ at $0^{\circ} \mathrm{C}$. The mixture was stirred for 20 min at $0^{\circ} \mathrm{C}$ and allyl bromide $(0.67 \mathrm{~mL}, 7.7 \mathrm{mmol}, 1.7$ equiv) was added dropwise. The mixture was allowed to warm to room temperature and stirred for $2 \mathrm{~h}$, before quenching the reaction by pouring it onto ice $(20 \mathrm{~g})$. The organic layer was diluted with $\mathrm{Et}_{2} \mathrm{O}(10 \mathrm{~mL})$ and separated from the aqueous one. The latter was extracted with $\mathrm{Et}_{2} \mathrm{O}(3 \times 10 \mathrm{~mL})$. The combined organic layers were washed with water $(4 \times 10 \mathrm{~mL})$ and brine $(10 \mathrm{~mL})$, were dried over $\mathrm{MgSO}_{4}$, filtered and concentrated in vacuo to afford ethyl 1-allyl-pyrrole-2-carboxylate (45) (794 mg, $4.43 \mathrm{mmol}, 95 \%$ yield) as an orange oil, which did not require further purification.

$1 \mathrm{M} \mathrm{NaOH}(12.5 \mathrm{~mL})$ was added to a solution of ethyl 1-allyl-pyrrole-2-carboxylate (45) (794 $\mathrm{mg}, 4.43 \mathrm{mmol})$ in EtOH $(10 \mathrm{~mL})$. The mixture was refluxed for $1.5 \mathrm{~h}$. EtOH was then evaporated under reduced pressure and the resulting aqueous solution was acidified to $\mathrm{pH} 2$ with $4 \mathrm{~N} \mathrm{HCl}$ and extracted with EtOAc $(3 \times 25 \mathrm{~mL})$. The combined organic layers were dried over $\mathrm{MgSO}_{4}$, filtered and concentrated in vacuo to afford 1-allyl- $1 \mathrm{H}$-pyrrole-2-carboxylic acid (46) (589 mg, $3.89 \mathrm{mmol}, 91 \%$ yield) as a brown solid, which did not require further purification.

${ }^{1} \mathrm{H}$ NMR (400 MHz, $\left.\mathrm{CDCl}_{3}\right) \delta 11.59$ (br s, $\left.1 \mathrm{H}, \mathrm{COOH}\right), 7.12$ (dd, $1 \mathrm{H}, J=3.9,1.8 \mathrm{~Hz}$, pyrrole), 6.91 (t, $1 \mathrm{H}, J=2.1 \mathrm{~Hz}$, pyrrole), 6.19 (dd, $1 \mathrm{H}, J=3.9,2.6 \mathrm{~Hz}$, pyrrole), 6.01 (ddt, $\left.1 \mathrm{H}, J=16.7,10.6,5.5 \mathrm{~Hz}, \mathrm{CH}_{2} \mathrm{CH}=\mathrm{CH}_{2}\right), 5.16\left(\mathrm{dd}, 1 \mathrm{H}, J=10.2,1.2 \mathrm{~Hz}, \mathrm{CH}_{2} \mathrm{CH}=\mathrm{CH}_{2}\right.$ ), 5.06-4.91 (m, $\left.3 \mathrm{H}, \mathrm{CH}_{2} \mathrm{CH}=\mathrm{CH}_{2}\right)$.

Following a reported procedure, ${ }^{[8]}$ DMAP $(1.13 \mathrm{~g}, 9.25 \mathrm{mmol}, 3.70$ equiv $)$ was added to a suspension of $\mathrm{EDCI} \cdot \mathrm{HCl}(767 \mathrm{mg}, 4.00 \mathrm{mmol}, 1.60$ equiv) in DCM (6.3 mL). The mixture

[17] L. Ruest, H. Ménard, V. Moreau, F. Laplante, Can. J. Chem. 2002, 80, 1662. 
was stirred at room temperature until all the solids dissolved and then it was cooled to $0^{\circ} \mathrm{C}$. 1 Allyl- $1 H$-pyrrole-2-carboxylic acid (46) (378 mg, $2.50 \mathrm{mmol}, 1.00$ equiv) was added, followed by $p$-toluenesulfonamide (514 $\mathrm{mg}, 3.00 \mathrm{mmol}, 1.20$ equiv) and the mixture was stirred at room temperature for $20 \mathrm{~h}$. $\mathrm{Et}_{2} \mathrm{O}(10 \mathrm{~mL})$ was then added and the organic mixture was washed with $2 \mathrm{~N} \mathrm{HCl}(15 \mathrm{~mL})$. The aqueous layer was extracted with EtOAc $(3 \times 20$ $\mathrm{mL}$ ). The combined organic layers were washed with brine, dried over $\mathrm{MgSO}_{4}$, filtered and concentrated in vacuo. Purification by column chromatography $\left(\mathrm{SiO}_{2}, \mathrm{DCM} / \mathrm{EtOAc} 90 / 10\right)$ afforded 1-allyl- $N$-tosyl- $1 H$-pyrrole-2-carboxamide (1k) (727 mg, $2.38 \mathrm{mmol}, 95 \%$ yield) as a colorless solid.

$\mathrm{R}_{\mathrm{f}} 0.25(\mathrm{Hex} / \mathrm{EtOAc} 4 / 1) ;{ }^{1} \mathrm{H}$ NMR $\left(400 \mathrm{MHz}, \mathrm{CDCl}_{3}\right) \delta 8.43(\mathrm{~m}, 1 \mathrm{H}, \mathrm{NH}), 8.00(\mathrm{~m}, 2 \mathrm{H}$, tosyl $\mathrm{CH}$ ), 7.34 (m, $2 \mathrm{H}$, tosyl $\mathrm{CH}), 6.87$ (m, $1 \mathrm{H}$, pyrrole), 6.78 (m, $1 \mathrm{H}$, pyrrole), 6.14 (dd, 1 $\mathrm{H}, J=4.1,2.6 \mathrm{~Hz}$, pyrrole), $5.90\left(\mathrm{~m}, 1 \mathrm{H}, \mathrm{CH}=\mathrm{CH}_{2}\right), 5.08(\mathrm{dq}, 1 \mathrm{H}, J=10.0,1.0 \mathrm{~Hz}$, $\left.\mathrm{CH}=\mathrm{CH}_{2}\right), 4.95\left(\mathrm{dq}, 1 \mathrm{H}, J=17.1,1.5 \mathrm{~Hz}, \mathrm{CH}=\mathrm{CH}_{2}\right), 4.85(\mathrm{dt}, 2 \mathrm{H}, J=5.8,1.4 \mathrm{~Hz}$, $\left.\mathrm{NCH}_{2} \mathrm{CH}=\mathrm{CH}_{2}\right), 2.44\left(\mathrm{~s}, 3 \mathrm{H}\right.$, tosyl $\left.\mathrm{CH}_{3}\right) ;{ }^{13} \mathrm{C} \mathrm{NMR}\left(101 \mathrm{MHz}, \mathrm{CDCl}_{3}\right) \delta 157.4,144.7$, $136.1,134.0,129.9,129.5,128.3,121.8,117.2,116.4,108.7,51.2,21.6$; IR 3276 (w), 3275 (w), 1682 (s), 1598 (w), 1529 (w), 1492 (w), 1426 (s), 1343 (m), 1235 (w), 1190 (w), 1165 (s), 1069 (s), 1017 (m), 996 (w), 907 (w), 875 (m), 874 (m), 813 (w), 742 (s), 703 (w), 662 (m), $615(\mathrm{w}), 614(\mathrm{w})$; Melting Point: $128.0-130.9^{\circ} \mathrm{C}$; HRMS (ESI) calcd for $\mathrm{C}_{15} \mathrm{H}_{17} \mathrm{~N}_{2} \mathrm{O}_{3} \mathrm{~S}^{+}$ $[\mathrm{M}+\mathrm{H}]^{+}$305.0954; found 305.0958.

\section{1-Allyl- $N$-tosyl-1H-indole-2-carboxamide (11)}<smiles>O=C(O)c1cc2ccccc2[nH]1</smiles>
47<smiles>C=CCn1c(C(=O)OCC)cc2ccccc21</smiles>

49

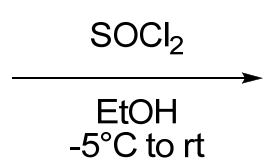

$-5^{\circ} \mathrm{C}$ to rt

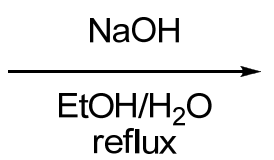

reflux<smiles>CCOC(=O)c1cc2ccccc2[nH]1</smiles>

48<smiles>C=CCn1c(C(=O)O)cc2ccccc21</smiles>

50
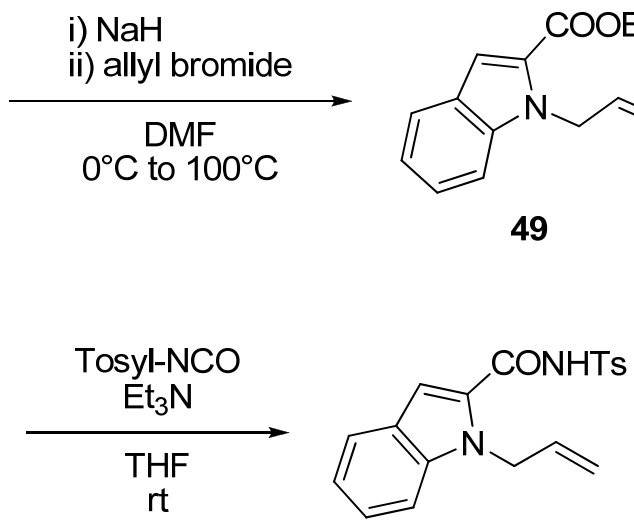

11

Following a reported procedure, ${ }^{[18]} \mathrm{SOCl}_{2}(0.92 \mathrm{~mL}, 13 \mathrm{mmol}, 1.8$ equiv) was added to a stirred solution of indole-2-carboxylic acid (47) (1.13 g, $7.00 \mathrm{mmol}, 1.0$ equiv) in EtOH (6.8 $\mathrm{mL})$ at $-5^{\circ} \mathrm{C}$. The mixture was allowed to warm to room temperature and stirred for $1 \mathrm{~h}$, before being refluxed for $2 \mathrm{~h}$. The mixture was then allowed to cool down to room temperature. The precipitated solid was washed with water, filtered and washed with water again (until $\mathrm{pH}$ 6) and cyclohexane. It was then dried under vacuum. Ethyl indole-2carboxylate (48) (1.154 g, $6.099 \mathrm{mmol}, 87 \%$ yield) was obtained as an off-white solid.

[18] A. Tsotinis, P. A. Afroudakis, K. Davidson, A. Prashar, D. Sugden, J. Med. Chem. 2007, 50, 6436. 
Ethyl indole-2-carboxylate (48) (1.135 g, $5.999 \mathrm{mmol}, 1.00$ equiv) was dissolved in DMF $(13.3 \mathrm{~mL})$ and the resulting solution was added dropwise to a suspension of $\mathrm{NaH}(158 \mathrm{mg}$, $6.58 \mathrm{mmol}, 1.10$ equiv) in DMF $(3.8 \mathrm{~mL})$ at $0^{\circ} \mathrm{C}$. The mixture was stirred for $30 \mathrm{~min}$ at room temperature and a solution of allyl bromide $(0.73 \mathrm{~mL}, 8.4 \mathrm{mmol}, 1.4$ equiv) was added dropwise. The mixture was stirred at $100^{\circ} \mathrm{C}$ for $1.5 \mathrm{~h}$ and then allowed to cool down to room temperature and poured into ice-cold water $(20 \mathrm{~mL})$. The organic layer was diluted with $\mathrm{Et}_{2} \mathrm{O}$ $(20 \mathrm{~mL})$ and separated from the aqueous one. The latter was extracted with $\mathrm{Et}_{2} \mathrm{O}(3 \times 25 \mathrm{~mL})$. The combined organic layers were washed with water $(5 \times 25 \mathrm{~mL})$ and brine $(25 \mathrm{~mL})$, were dried over $\mathrm{MgSO}_{4}$, filtered and concentrated in vacuo to afford ethyl 1-allyl-indole-2carboxylate (49) (1.38 g, $6.00 \mathrm{mmol}$, quantitative) as a yellow oil, which was not further purified.

Ethyl 1-allyl-indole-2-carboxylate (49) (1.38 g, $6.00 \mathrm{mmol})$ was dissolved in EtOH (15 mL) and $1 \mathrm{~N} \mathrm{NaOH}(15 \mathrm{~mL})$ was added to the resulting solution. The mixture was refluxed for $2 \mathrm{~h}$ and then allowed to cool down to room temperature. EtOH was evaporated under reduced pressure and the aqueous layer was diluted with water $(15 \mathrm{~mL})$ and washed with $\mathrm{Et}_{2} \mathrm{O}(2 \times 30$ $\mathrm{mL})$. It was then acidified with $4 \mathrm{M} \mathrm{HCl}$ until $\mathrm{pH} 2$ and extracted with EtOAc $(3 \times 30 \mathrm{~mL})$. The combined organic layers were dried over $\mathrm{MgSO}_{4}$, filtered and concentrated in vacuo to afford 1-allyl-indole-2-carboxylic acid (50) (966 mg, $4.80 \mathrm{mmol}, 80 \%$ yield) as an off-white solid, which did not required further purification.

${ }^{1} \mathrm{H}$ NMR (400 MHz, $\mathrm{CDCl}_{3}$ ) $\delta 10.92$ (br s, $\left.1 \mathrm{H}, \mathrm{COOH}\right), 7.72(\mathrm{~m}, 1 \mathrm{H}$, indole), 7.50 (s, $1 \mathrm{H}$, indole), $7.38\left(\mathrm{~m}, 2 \mathrm{H}\right.$, indole), $7.18\left(\mathrm{~m}, 1 \mathrm{H}\right.$, indole), $6.02\left(\mathrm{~m}, 1 \mathrm{H}, \mathrm{CH}_{2} \mathrm{CH}=\mathrm{CH}_{2}\right), 5.25$ (dt, 2 $\left.\mathrm{H}, J=4.9,1.6 \mathrm{~Hz}, \mathrm{CH}_{2} \mathrm{CH}=\mathrm{CH}_{2}\right), 5.12\left(\mathrm{~m}, 1 \mathrm{H}, \mathrm{CH}_{2} \mathrm{CH}=\mathrm{CH}_{2}\right), 4.92\left(\mathrm{~m}, 1 \mathrm{H}, \mathrm{CH}_{2} \mathrm{CH}=\mathrm{CH}_{2}\right)$.

Following a reported procedure, ${ }^{[7]} p$-tosyl isocyanate $(592 \mathrm{mg}, 3.00 \mathrm{mmol}, 1.00$ equiv) was added to a solution of 1-allyl-indole-2-carboxylic acid (50) (604 mg, $3.00 \mathrm{mmol}, 1.00$ equiv) in THF $(8.4 \mathrm{~mL})$. After stirring the resulting clear solution at room temperature for $10 \mathrm{~min}$, triethylamine $(0.42 \mathrm{~mL}, 3.0 \mathrm{mmol}, 1.0$ equiv) was added dropwise, with release of gas. After $1 \mathrm{~h}$, the mixture was diluted with EtOAc $(9 \mathrm{~mL})$ and washed with $2 \mathrm{M} \mathrm{HCl}(9 \mathrm{~mL})$ and $\mathrm{NaCl}$ (saturated solution, $9 \mathrm{~mL}$ ). The organic layer was dried over $\mathrm{MgSO}_{4}$, filtered and concentrated in vacuo. Purification by column chromatography $\left(\mathrm{SiO}_{2}, \mathrm{PET} / \mathrm{EtOAc} 95 / 5\right.$ to 90/10) afforded 1-allyl- $N$-tosyl- $1 H$-indole-2-carboxamide (11) (928 mg, $2.62 \mathrm{mmol}, 87 \%$ ) as a colorless solid.

$\mathrm{R}_{\mathrm{f}} 0.43\left(\mathrm{PET} /\right.$ EtOAc 5/1); ${ }^{1} \mathrm{H}$ NMR $\left(400 \mathrm{MHz}, \mathrm{CDCl}_{3}\right) \delta 9.21(\mathrm{~s}, 1 \mathrm{H}, \mathrm{NH}), 8.07$ (m, $2 \mathrm{H}$, tosyl $\mathrm{CH}$ ), 7.63 (d, $1 \mathrm{H}, J=8.1 \mathrm{~Hz}$, indole), 7.38-7.31 (m, $4 \mathrm{H}$, tosyl $\mathrm{CH}$ and indole), 7.19 (m, $1 \mathrm{H}$, indole), 7.14 (ddd, $1 \mathrm{H}, J=8.0,5.5,2.5 \mathrm{~Hz}$, indole), $5.88\left(\mathrm{~m}, 1 \mathrm{H}, \mathrm{NCH}_{2} \mathrm{CH}=\mathrm{CH}_{2}\right), 5.07$ (dt, $\left.1 \mathrm{H}, J=5.0,1.5 \mathrm{~Hz}, \mathrm{NCH}_{2} \mathrm{CH}=\mathrm{CH}_{2}\right), 5.02\left(\mathrm{~m}, 1 \mathrm{H} ; \mathrm{NCH}_{2} \mathrm{CH}=\mathrm{CH}_{2}\right), 4.84$ (dq, $1 \mathrm{H}, J=$ 17.6, $\left.1.5 \mathrm{~Hz}, \mathrm{NCH}_{2} \mathrm{CH}=\mathrm{CH}_{2}\right), 2.43\left(\mathrm{~s}, 3 \mathrm{H}\right.$, tosyl $\left.\mathrm{CH}_{3}\right) ;{ }^{13} \mathrm{C} \mathrm{NMR}\left(101 \mathrm{MHz}, \mathrm{CDCl}_{3}\right) \delta 158.7$, $145.0,139.6,135.7,133.4,129.6,128.4,127.3,125.8,125.7,122.8,121.2,116.5,110.7$, 108.8, 46.9, 21.7; IR 3266 (w), $3070(w), 2928(w), 2362(w), 1923(w), 1757(w), 1757(w)$, $1688(\mathrm{~m}), 1646$ (w), 1615 (w), 1615 (w), 1597 (w), 1597 (w), $1579(\mathrm{w}), 1578$ (w), $1516(\mathrm{~m})$, 1494 (w), 1494 (w), 1479 (m), 1458 (m), 1429 (m), 1396 (m), 1373 (w), 1341 (m), 1309 (w), 1295 (w), 1257 (w), 1239 (w), 1239 (w), 1196 (m), 1184 (m), 1161 (s), $1136(\mathrm{w}), 1136$ (w), $1118(\mathrm{w}), 1118(\mathrm{w}), 1076(\mathrm{~m}), 1019(\mathrm{w}), 991(\mathrm{w}), 981(\mathrm{w}), 968(\mathrm{w}), 968(\mathrm{w}), 960(\mathrm{w}), 911$ 
(m), $884(\mathrm{~m}), 850(\mathrm{~m}), 814(\mathrm{~m}), 800(\mathrm{w}), 800(\mathrm{w}), 759(\mathrm{~m}), 743$ (s), $704(\mathrm{w}), 704(\mathrm{w}), 687$ $(\mathrm{w}), 687(\mathrm{w}), 682(\mathrm{w}), 682(\mathrm{w}), 663(\mathrm{~m}), 628(\mathrm{w}), 615(\mathrm{w})$; Melting Point: 185.3 - $187.2^{\circ} \mathrm{C}$; HRMS (ESI) calcd for $\mathrm{C}_{19} \mathrm{H}_{19} \mathrm{~N}_{2} \mathrm{O}_{3} \mathrm{~S}^{+}\left(\mathrm{M}+\mathrm{H}^{+}\right)$355.1116; found: 355.1119 .

\section{Methyl- $N$-(4-nitrophenylsulfonyl)pent-4-enamide (1m)}<smiles>CC(=O)CCC(=O)O</smiles>

51

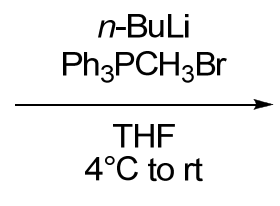

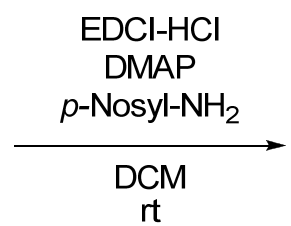

52

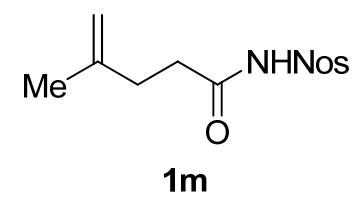

$1 \mathrm{~m}$

Following a reported procedure, ${ }^{[19]}$ methyltriphenylphosphonium bromide $(7.50 \mathrm{~g}, 21.0$ mmol, 3.0 equiv) was suspended in THF $(90 \mathrm{~mL})$. The colorless suspension was cooled to 0 ${ }^{\circ} \mathrm{C}$ and $n$-BuLi (2.5 $\mathrm{M}$ in hexanes) (13.1 mL, $21.0 \mathrm{mmol}, 3.0$ equiv) was added dropwise. The resulting bright orange solution was stirred at $0{ }^{\circ} \mathrm{C}$ for $1 \mathrm{~h}$ before the dropwise addition of levulinic acid (51) (0.81 g, $7.0 \mathrm{mmol}, 1.0$ equiv). The suspension was allowed to warm to room temperature and stirred overnight. The reaction was then quench by adding a $1 \mathrm{M} \mathrm{HCl}$ solution $(30 \mathrm{~mL})$ and the aqueous layer was extracted with $\mathrm{Et}_{2} \mathrm{O}(3 \times 90 \mathrm{~mL})$. The combined organic layers were dried over $\mathrm{MgSO}_{4}$, filtered and concentrated under reduced pressure. The crude product was purified by column chromatography $\left(\mathrm{SiO}_{2}, \mathrm{PET} / \mathrm{EtOAc} / \mathrm{AcOH} 85 / 15 / 0.1\right)$ to afford 4-methylpent-4-enoic acid (52) (542 $\mathrm{mg}, 4.74 \mathrm{mmol}, 62 \%$ yield) as a clear yellowish oil.

${ }^{1} \mathrm{H}$ NMR (400MHz, CDCl3) $\delta 9.74$ (br s, $\left.1 \mathrm{H}, \mathrm{COOH}\right), 4.77\left(\mathrm{~m}, 1 \mathrm{H}, \mathrm{C}=\mathrm{CH}_{2}\right), 4.71(\mathrm{~d}, 1 \mathrm{H}, J$ $\left.=0.7 \mathrm{~Hz}, \mathrm{C}=\mathrm{CH}_{2}\right), 2.54\left(\mathrm{~m}, 2 \mathrm{H}, \mathrm{CH}_{2} \mathrm{COOH}\right), 2.37\left(\mathrm{t}, 2 \mathrm{H}, J=8.2 \mathrm{~Hz}, \mathrm{CH}_{2} \mathrm{C}=\mathrm{CH}_{2}\right), 1.75(\mathrm{~d}$, $3 \mathrm{H}, \mathrm{J}=0.4 \mathrm{~Hz}, \mathrm{CH}_{3} \mathrm{C}=\mathrm{CH}_{2}$ ).

Following a slightly modified version of a reported procedure, ${ }^{[8]}$ DMAP $(723 \mathrm{mg}, 5.92 \mathrm{mmol}$, 3.70 equiv) was added to a suspension of $\mathrm{EDCI} \cdot \mathrm{HCl}(490 \mathrm{mg}, 2.56 \mathrm{mmol}, 1.60$ equiv) in DCM (4 mL). The mixture was stirred at room temperature until all the solids dissolved and then it was cooled to $0^{\circ} \mathrm{C}$. 4-methylpent-4-enoic acid (52) (183 mg, $1.60 \mathrm{mmol}, 1.00$ equiv) was added, followed by $p$-nitrobenzenesulfonamide (453 $\mathrm{mg}, 2.24 \mathrm{mmol}, 1.40$ equiv) and the mixture was stirred at room temperature for $24 \mathrm{~h} . \mathrm{Et}_{2} \mathrm{O}(10 \mathrm{~mL})$ was then added and the organic mixture was washed with $2 \mathrm{~N} \mathrm{HCl}(15 \mathrm{~mL})$. The aqueous layer was extracted with EtOAc $(3 \times 15 \mathrm{~mL})$. The combined organic layers were washed with brine, dried over $\mathrm{MgSO}_{4}$, filtered and concentrated in vacuo. Purification by column chromatography $\left(\mathrm{SiO}_{2}\right.$, DCM/EtOAc 90/10 to 70/30) afforded 4-methyl- $N$-(4-nitrophenylsulfonyl)pent-4-enamide (1m) (387 mg, $1.30 \mathrm{mmol}, 81 \%$ yield) as a colorless solid.

$\mathrm{R}_{\mathrm{f}} 0.30(\mathrm{PET} / \mathrm{EtOAc} / \mathrm{AcOH}=15 / 5 / 0.2) ;{ }^{1} \mathrm{H} \mathrm{NMR}\left(400 \mathrm{MHz}, \mathrm{CDCl}_{3}\right) \delta 8.47$ (br s, $\left.1 \mathrm{H}, \mathrm{NH}\right)$, 8.39 (m, $2 \mathrm{H}$, Nosyl CH), 8.28 (m, $2 \mathrm{H}$, Nosyl CH), $4.74\left(\mathrm{~d}, 1 \mathrm{H}, \mathrm{J}=0.6 \mathrm{~Hz}, \mathrm{C}=\mathrm{CH}_{2}\right), 4.60$ $\left(\mathrm{d}, 1 \mathrm{H}, J=0.5 \mathrm{~Hz}, \mathrm{C}=\mathrm{CH}_{2}\right), 2.44\left(\mathrm{~m}, 2 \mathrm{H}, \mathrm{COCH}_{2} \mathrm{CH}_{2}\right), 2.28(\mathrm{t}, 2 \mathrm{H}, J=7.5 \mathrm{~Hz}$, $\left.\mathrm{COCH}_{2} \mathrm{CH}_{2}\right), 1.68\left(\mathrm{~s}, 3 \mathrm{H}, \mathrm{CH}_{3}\right) ;{ }^{13} \mathrm{C}$ NMR $\left(101 \mathrm{MHz}, \mathrm{CDCl}_{3}\right) \delta 170.1,150.8,143.8,143.0$, 130.0, 124.2, 111.4, 34.5, 31.7, 22.3; IR 3250 (w), 3109 (w), 3090 (w), 2977 (w), 2909 (w),

[19] S. Nicolai, S. Erard, D. Fernández González, J. Waser, Org. Lett., 2010, 12, 384. 
$1724(\mathrm{~m}), 1651(\mathrm{w}), 1609$ (w), 1535 (s), 1505 (w), 1442 (s), 1352 (s), $1315(\mathrm{~m}), 1294(\mathrm{w})$, 1179 (s), 1124 (m), 1088 (s), 1051 (w), 1014 (w), 961 (w), 910 (m), 869 (m), 849 (s), 815 (w), $782(\mathrm{w}), 772(\mathrm{w}), 764(\mathrm{w}), 740(\mathrm{~s}), 711(\mathrm{w}), 702(\mathrm{w}), 697(\mathrm{w}), 685(\mathrm{~m}), 650(\mathrm{w}), 638$ $(\mathrm{w}), 626(\mathrm{~m}), 612(\mathrm{~s})$; Melting point: $73.3-75.8^{\circ} \mathrm{C}$; HRMS (ESI) calcd for $\mathrm{C}_{12} \mathrm{H}_{15} \mathrm{~N}_{2} \mathrm{O}_{5} \mathrm{~S}^{+}$ $\left(\mathrm{M}+\mathrm{H}^{+}\right)$299.0702; found: 299.0709 .

\section{Procedure for the preparation of allyl tosylcarbamates $(6 a, b, e)$}

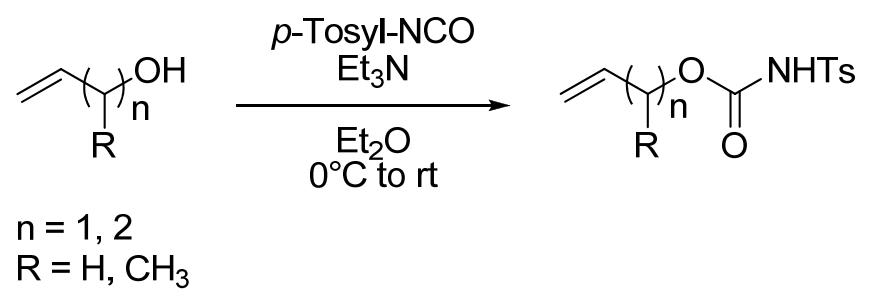

Following a reported procedure, ${ }^{[20]}$ triethyl amine $(0.56 \mathrm{~mL}, 4.0 \mathrm{mmol}, 1.0$ equiv $)$ was added dropwise to a solution of allyl alcohol ( $4.0 \mathrm{mmol}, 1.0$ equiv) in $\mathrm{Et}_{2} \mathrm{O}(4 \mathrm{~mL})$ at $0^{\circ} \mathrm{C}$. $p$-tosyl isocyanate ( $789 \mathrm{mg}, 4.00 \mathrm{mmol}, 1.0$ equiv) was then added at $0^{\circ} \mathrm{C}$. The resulting off-white suspension was allowed to warm to $\mathrm{rt}$ and stirred for $2.5 \mathrm{~h}$. The mixture was then diluted with EtOAc $(4 \mathrm{~mL})$ and the organic layer was washed with $2 \mathrm{~N} \mathrm{HCl}(4 \mathrm{~mL})$. The aqueous layer was extracted with EtOAc $(3 \times 10 \mathrm{~mL})$. The combined organic layers were washed with brine $(10 \mathrm{~mL})$, dried over $\mathrm{MgSO}_{4}$, filtered and concentrated in vacuo. Purification by column chromatography afforded allyl tosylcarbamate $\mathbf{6 a}, \mathbf{b}, \mathbf{e}$.

\section{Allyl tosylcarbamate (6a)}<smiles>C=CCOC(=O)N[AsH3]</smiles>

Column chromatography $\left(\mathrm{SiO}_{2}, \mathrm{PET} /\right.$ EtOAc $90 / 10$ to $\left.80 / 20\right)$ afforded product $6 \mathbf{a}(1.02 \mathrm{~g}, 4.00 \mathrm{mmol}$, quantitative) as a viscous, colorless oil.

$\mathrm{R}_{\mathrm{f}} 0.26$ (PET/EtOAc 4/1); ${ }^{1} \mathrm{H}$ NMR (400 MHz, $\left.\mathrm{CDCl}_{3}\right) \delta 8.17$ (br s, $1 \mathrm{H}$, $\mathrm{NH}), 7.92(\mathrm{~m}, 2 \mathrm{H}$, tosyl $\mathrm{CH}), 7.32(\mathrm{~m}, 2 \mathrm{H}$, tosyl $\mathrm{CH}), 5.80\left(\mathrm{~m}, 1 \mathrm{H}, \mathrm{CH}=\mathrm{CH}_{2}\right), 5.25$ (ddd, 1 $\left.\mathrm{H}, J=17.2,2.9,1.5 \mathrm{~Hz}, \mathrm{CH}=\mathrm{CH}_{2}\right), 5.20\left(\mathrm{~d}, 1 \mathrm{H}, J=10.3 \mathrm{~Hz}, \mathrm{CH}=\mathrm{CH}_{2}\right), 4.55(\mathrm{dt}, 2 \mathrm{H}, J=$ 5.7, $\left.1.2 \mathrm{~Hz}, \mathrm{CH}_{2} \mathrm{CH}=\mathrm{CH}_{2}\right), 2.43\left(\mathrm{~s}, 3 \mathrm{H}\right.$, tosyl $\left.\mathrm{CH}_{3}\right) ;{ }^{13} \mathrm{C} \mathrm{NMR}\left(101 \mathrm{MHz}, \mathrm{CDCl}_{3}\right) \delta 150.3$, 145.0, 135.3, 130.8, 129.5, 128.3, 119.2, 67.3, 21.6; IR 3613 (w), 3238 (w), 3237 (w), 2993 (w), $2884(\mathrm{w}), 2826(\mathrm{w}), 2362(\mathrm{w}), 2344(\mathrm{w}), 1750(\mathrm{~m}), 1650(\mathrm{w}), 1598(\mathrm{w}), 1495(\mathrm{w}), 1448$ (m), $1421(\mathrm{~m}), 1345$ (m), 1308 (w), $1291(\mathrm{w}), 1284(\mathrm{w}), 1223$ (m), 1187 (m), 1158 (s), 1122 (w), $1090(\mathrm{~s}), 1069(\mathrm{w}), 1020(\mathrm{w}), 994(\mathrm{w}), 950(\mathrm{w}), 914(\mathrm{w}), 858(\mathrm{~s}), 816(\mathrm{~m}), 770(\mathrm{~m}), 734$ $(\mathrm{m}), 705(\mathrm{w}), 687(\mathrm{w}), 678(\mathrm{w}), 670(\mathrm{~s}), 664(\mathrm{~s}), 636(\mathrm{w}), 620(\mathrm{w}), 609(\mathrm{w})$; the reported values for $6 \mathbf{a}$ corresponded to the ones in literatures. ${ }^{[21]}$

\section{But-3-en-2-yl tosylcarbamate (6b)}<smiles>[3H]NC(=O)OC(C)C=C</smiles>

Column chromatography $\left(\mathrm{SiO}_{2}, \mathrm{DCM} / \mathrm{EtOAc} / \mathrm{AcOH}\right.$ 95/5/0.1) afforded product $\mathbf{6 b}(907 \mathrm{mg}, 3.37 \mathrm{mmol}, 84 \%)$ as a viscous, colorless oil.

$\mathrm{R}_{\mathrm{f}} 0.47(\mathrm{PET} / \mathrm{EtOAc} 4 / 1) ;{ }^{1} \mathrm{H}$ NMR $\left(400 \mathrm{MHz}, \mathrm{CDCl}_{3}\right) \delta 7.92(\mathrm{~m}, 2 \mathrm{H}$, tosyl $\mathrm{CH}$ ), 7.51 (br s, $1 \mathrm{H}, \mathrm{NH}), 7.34(\mathrm{~m}, 2 \mathrm{H}$, tosyl $\mathrm{CH}$ ), 5.73 (ddd, $1 \mathrm{H}, J=17.4,10.5,6.0$ $\left.\mathrm{Hz}, \mathrm{CH}=\mathrm{CH}_{2}\right), 5.25-5.10\left(\mathrm{~m}, 3 \mathrm{H}, \mathrm{CH}=\mathrm{CH}_{2}\right.$ and $\left.\mathrm{OCHCH}_{3}\right), 2.45\left(\mathrm{~s}, 3 \mathrm{H}\right.$, tosyl $\left.\mathrm{CH}_{3}\right), 1.27(\mathrm{~d}$,

[20] Y. Tamaru, M. Kimura, S. Tanaka, S. Kure, Z. Yoshida, Bull. Chem. Soc. Jpn. 1994, 67, 2838.

[21] D. Xing, D. Yang, Org. Lett. 2010, 12, 1068. 
$\left.3 \mathrm{H}, J=6.5 \mathrm{~Hz}, \mathrm{OCHCH}_{3}\right) ;{ }^{13} \mathrm{C} \mathrm{NMR}\left(101 \mathrm{MHz}, \mathrm{CDCl}_{3}\right) \delta 149.9,144.9,136.2,135.5,129.5$, 128.3, 116.7, 74.3, 21.6, 19.7; IR 3616 (w), 3320 (w), 3238 (w), 2986 (w), 1743 (m), 1650 (w), $1598(\mathrm{w}), 1441(\mathrm{~m}), 1351(\mathrm{~m}), 1308(\mathrm{w}), 1291(\mathrm{w}), 1290(\mathrm{w}), 1226(\mathrm{~m}), 1187(\mathrm{w}), 1160$ (s), 1121 (w), 1108 (w), 1089 (s), 1039 (m), 992 (w), 915 (m), 874 (m), 816 (m), 771 (m), $733(\mathrm{~m}), 706(\mathrm{w}), 665(\mathrm{~s})$; HRMS (ESI) calcd for $\mathrm{C}_{12} \mathrm{H}_{15} \mathrm{NNaO}_{4} \mathrm{~S}^{+}[\mathrm{M}+\mathrm{Na}]^{+}$292.0614; found 292.0625 .

\section{But-3-enyl tosylcarbamate (6d)}

Column chromatography $\left(\mathrm{SiO}_{2}, \mathrm{DCM} / \mathrm{EtOAc} / \mathrm{AcOH} 90 / 10 / 0.2\right)$ afforded product $6 \mathbf{d}(1.00 \mathrm{~g}$, $3.73 \mathrm{mmol}, 93 \%$ ) as a viscous, colorless oil.

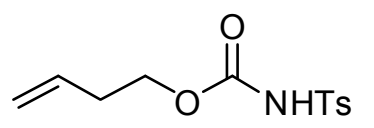

$\mathrm{R}_{\mathrm{f}} 0.39(\mathrm{Hex} / \mathrm{EtOAc} 4 / 1) ;{ }^{1} \mathrm{H}$ NMR (400 MHz, $\left.\mathrm{CDCl}_{3}\right) \delta 7.91(\mathrm{~m}, 2$ $\mathrm{H}$, tosyl $\mathrm{CH}){ }^{[22]} 7.42-7.31(\mathrm{~m}, 3 \mathrm{H}$, tosyl $\mathrm{CH}$ and $\mathrm{NH}), 5.67(\mathrm{~m}, 1 \mathrm{H}$, $\left.\mathrm{CH}=\mathrm{CH}_{2}\right), 5.06\left(\mathrm{~m}, 1 \mathrm{H}, \mathrm{CH}=\mathrm{CH}_{2}\right), 5.03\left(\mathrm{~m}, 1 \mathrm{H}, \mathrm{CH}=\mathrm{CH}_{2}\right), 4.13(\mathrm{t}, 2$ $\left.\mathrm{H}, J=6.7 \mathrm{~Hz}, \mathrm{OCH}_{2}\right), 2.45\left(\mathrm{~s}, 3 \mathrm{H}\right.$, tosyl $\left.\mathrm{CH}_{3}\right), 2.33\left(\mathrm{~m}, 2 \mathrm{H}, \mathrm{CH}_{2} \mathrm{CH}=\mathrm{CH}_{2}\right) ;{ }^{13} \mathrm{C} \mathrm{NMR}(101$ $\left.\mathrm{MHz}, \mathrm{CDCl}_{3}\right) \delta 150.6,144.9,135.4,133.0,129.5,128.2,117.6,65.8,32.6,21.5 ;$ IR 3541 (w), $3242(\mathrm{w}), 3234(\mathrm{w}), 3080(\mathrm{w}), 3079(\mathrm{w}), 2980(\mathrm{w}), 2965(\mathrm{w}), 2259(\mathrm{w}), 1748(\mathrm{~m}), 1644$ (w), 1598 (w), $1445(\mathrm{~m}), 1382(\mathrm{w}), 1382(\mathrm{w}), 1348(\mathrm{~m}), 1306(\mathrm{w}), 1306(\mathrm{w}), 1292(\mathrm{w}), 1224$ (m), 1185 (w), 1185 (w), 1160 (s), 1089 (m), 994 (w), 912 (m), 864 (w), 817 (m), $771(\mathrm{w})$, $733(\mathrm{~m}), 703(\mathrm{w}), 662(\mathrm{~s}) ;{ }^{1} \mathrm{H}$ and ${ }^{13} \mathrm{C}$ values correspond to the ones in literature. ${ }^{[23]}$

\section{1-Cyclohexylallyl tosylcarbamate (6c)}<smiles>O=CC1CCCCC1</smiles>

53

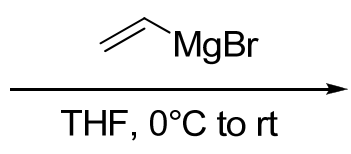

$\mathrm{THF}, \mathrm{O}^{\circ} \mathrm{C}$ to $\mathrm{rt}$

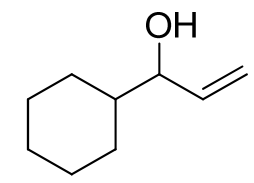

54

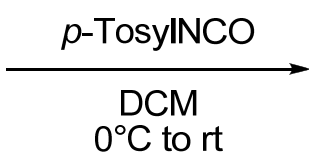

$0^{\circ} \mathrm{C}$ to rt<smiles>C=CC(OC(=O)N[I-])C1CCCCC1</smiles>

6c

Following a reported procedure, ${ }^{[24]}$ vinyl magnesium bromide $(0.7 \mathrm{M}$ in THF, $12 \mathrm{~mL}, 8.4$ mmol, 1.2 equiv) was diluted in THF $(10 \mathrm{~mL})$ and the reaction mixture was stirred at $0^{\circ} \mathrm{C}$ for $10 \mathrm{~min}$. Cyclohexanecarboxaldehyde (53) $(785 \mathrm{mg}, 7.00 \mathrm{mmol}, 1.00$ equiv) was added dropwise and the resulting mixture was stirred at $0^{\circ} \mathrm{C}$ for $4 \mathrm{~h}$. The reaction was then quenched by addition of a saturated solution of $\mathrm{NH}_{4} \mathrm{Cl}$ (ca $15 \mathrm{~mL}$ ). The aqueous layer was separated from the organic one and extracted with EtOAc $(3 \times 20 \mathrm{~mL})$. The combined organic layers were dried over $\mathrm{MgSO}_{4}$, filtered and concentrated in vacuo. Purification by column chromatography affored 1-cyclohexylprop-2-en-1-ol (54) (780 mg, $5.54 \mathrm{mmol}, 79 \%)$ as a colorless oil.

1-Cyclohexylprop-2-en-1-ol (54) (780 mg, $5.54 \mathrm{mmol}, 1.00$ equiv) was dissolved in DCM $(11 \mathrm{~mL})$ and the solution was cooled to $0^{\circ} \mathrm{C}$. $p$-Tosyl isocyanate $(1.11 \mathrm{~g}, 5.65 \mathrm{mmol}, 1.02$ equiv) was added dropwise and, after $10 \mathrm{~min}$, the mixture was allowed to warm to $\mathrm{rt}$ under

[22] The value for the peak at $7.91 \mathrm{ppm}$ is different from the reported one in the literature (7.81 ppm) but corresponds better to what is expected for this proton signal.

[23] F. Nahra, F. Liron, G. Prestat, G. Poli, C. Mealli, A. Messaoudi, Chem. Eur. J. 2009, 15, 11078.

(24) Bergmeier, S.C.; Stanchina, D. M. J. Org. Chem 1997, 62, 4449. 
stirring. After $1.5 \mathrm{~h}, \mathrm{DCM}$ was evaporated and the resulting oil was dissolved in EtOAc (11 $\mathrm{mL})$ and washed with water $(11 \mathrm{~mL})$. The aqueous layer was extracted with EtOAc $(2 \times 11$ $\mathrm{mL}$ ) and the combined organic layers were dried over $\mathrm{MgSO}_{4}$, filtered and concentrated in vacuo. Purification by column chromatography $\left(\mathrm{SiO}_{2}, \mathrm{PET} /\right.$ EtOAC $90 / 10$ to $\left.75 / 25\right)$ afforded 1-cyclohexylallyl tosylcarbamate (6c) (1.76 g, $5.22 \mathrm{mmol}, 94 \%$ yield) as a colorless solid.

$\mathrm{R}_{\mathrm{f}} 0.47$ (PET/EtOAc 2/1); ${ }^{1} \mathrm{H}$ NMR $\left(400 \mathrm{MHz}, \mathrm{CDCl}_{3}\right) \delta 7.90(\mathrm{~m}, 2 \mathrm{H}$, tosyl CH), 7.70 (br s, $1 \mathrm{H}, \mathrm{NH}), 7.33(\mathrm{~d}, 2 \mathrm{H}, J=8.2 \mathrm{~Hz}$, tosyl $\mathrm{CH}$ ), 5.63 (ddd, $1 \mathrm{H}, J=17.2,10.9,7.0 \mathrm{~Hz}$, $\left.\mathrm{CH}=\mathrm{CH}_{2}\right), 5.16\left(\mathrm{~m}, 1 \mathrm{H}, \mathrm{CH}=\mathrm{CH}_{2}\right), 5.12\left(\mathrm{~m}, 1 \mathrm{H}, \mathrm{CH}=\mathrm{CH}_{2}\right), 2.44\left(\mathrm{~s}, 3 \mathrm{H}\right.$, tosyl $\left.\mathrm{CH}_{3}\right), 1.76-$ 1.37 (m, $6 \mathrm{H}, \mathrm{cy}), 1.20-0.99$ (m, $3 \mathrm{H}, \mathrm{cy}), 0.94-0.77$ (m, $2 \mathrm{H}, \mathrm{cy}) ;{ }^{13} \mathrm{C}$ NMR (101 MHz, $\left.\mathrm{CDCl}_{3}\right) \delta 150.0,144.9,135.7,133.6,129.5,128.2,118.4,82.4,41.4,28.2,28.0,26.1,25.7$, 21.6; ${ }^{25}$ IR $3245(\mathrm{w}), 2929(\mathrm{~m}), 2854(\mathrm{w}), 1748(\mathrm{~m}), 1595(\mathrm{w}), 1449(\mathrm{~m}), 1355(\mathrm{~m}), 1305(\mathrm{w})$, $1287(\mathrm{~m}), 1226(\mathrm{~m}), 1187(\mathrm{w}), 1162$ (s), $1117(\mathrm{w}), 1091(\mathrm{~m}), 1049(\mathrm{w}), 1021(\mathrm{w}), 989(\mathrm{w})$, $954(\mathrm{~m}), 894(\mathrm{w}), 860(\mathrm{~m}), 842(\mathrm{w}), 816(\mathrm{w}), 769(\mathrm{w}), 737(\mathrm{w}), 736(\mathrm{w}), 705(\mathrm{w}), 665(\mathrm{~m})$, 619 (w); Melting point: $84.0-88.0^{\circ} \mathrm{C}$; HRMS (ESI) calcd for $\mathrm{C}_{17} \mathrm{H}_{23} \mathrm{NNaO}_{4} \mathrm{~S}^{+}[\mathrm{M}+\mathrm{Na}]^{+}$ 360.1240 ; found 360.1232 .

\section{$N$-(Allylcarbamoyl)-4-methylbenzenesulfonamide (6e)}

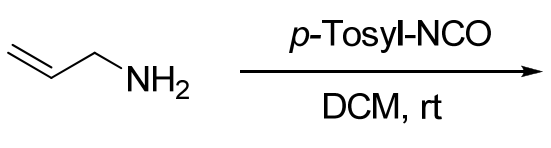

55<smiles>C=CCNC(=O)N[AsH3]</smiles>

$6 e$

Allyl amine (55) (342 mg, 5.99 mmol, 1.0 equiv) was dissolved in DCM (12 mL) and the solution was cooled to $0^{\circ} \mathrm{C}$. $p$-Tosyl isocyanate $(1.21 \mathrm{~g}, 6.12 \mathrm{mmol}, 1.02$ equiv) was added dropwise and, after $10 \mathrm{~min}$, the mixture was allowed to warm to rt under stirring. After $1.5 \mathrm{~h}$, DCM was evaporated and the resulting oil was dissolved in EtOAc $(12 \mathrm{~mL})$ and washed with water $(10 \mathrm{~mL})$. The aqueous layer was extracted with EtOAc $(2 \times 12 \mathrm{~mL})$ and the combined organic layers were dried over $\mathrm{MgSO}_{4}$, filtered and concentrated in vacuo. No further purification was required. 2-Methylbut-3-en-2-yl tosylcarbamate 6e (1.14 g, $4.50 \mathrm{mmol}, 75 \%$ yield) was obtained as a colorless solid.

$\mathrm{R}_{\mathrm{f}} 0.10(\mathrm{Hex} / \mathrm{EtOAc} 4 / 1) ;{ }^{1} \mathrm{H}$ NMR $\left(400 \mathrm{MHz}, \mathrm{CDCl}_{3}\right) \delta 7.78(\mathrm{~m}, 2 \mathrm{H}$, tosyl CH), 7.33 (m, 2 $\mathrm{H}$, tosyl $\mathrm{CH}), 6.67(\mathrm{~s}, 1 \mathrm{H}, \mathrm{NH}), 5.78\left(\mathrm{~m}, 1 \mathrm{H}, \mathrm{CH}_{2} \mathrm{CH}=\mathrm{CH}_{2}\right), 5.15\left(\mathrm{~m}, 1 \mathrm{H}, \mathrm{CH}_{2} \mathrm{CH}=\mathrm{CH}_{2}\right)$, $5.12\left(\mathrm{~m}, 1 \mathrm{H}, \mathrm{CH}_{2} \mathrm{CH}=\mathrm{CH}_{2}\right), 3.85\left(\mathrm{~m}, 2 \mathrm{H}, \mathrm{CH}_{2} \mathrm{CH}=\mathrm{CH}_{2}\right), 2.45\left(\mathrm{~s}, 3 \mathrm{H}\right.$, tosyl $\left.\mathrm{CH}_{3}\right) ;{ }^{13} \mathrm{C} \mathrm{NMR}$ $\left(101 \mathrm{MHz}, \mathrm{CDCl}_{3}\right) \delta 151.6,144.9,136.6,133.4,129.9,126.9,116.5,42.6,21.6$; IR $3339(\mathrm{w})$, 3187 (w), 3099 (w), 2914 (w), 1668 (s), 1646 (w), 1598 (w), 1543 (m), 1495 (w), 1458 (m), 1342 (m), 1275 (w), 1265 (w), 1247 (w), 1241 (w), 1188 (w), 1165 (s), 1091 (m), 1055 (w), $991(\mathrm{w}), 943(\mathrm{w}), 917(\mathrm{w}), 877(\mathrm{w}), 815(\mathrm{w}), 734(\mathrm{w}), 715(\mathrm{w}), 705(\mathrm{w}), 693(\mathrm{w}), 669(\mathrm{~s}), 641$ (m); Melting point: $140.5-144.0^{\circ} \mathrm{C}$; HRMS (ESI) calcd for $\mathrm{C}_{11} \mathrm{H}_{15} \mathrm{~N}_{2} \mathrm{O}_{3} \mathrm{~S}^{+}[\mathrm{M}+\mathrm{H}]^{+}$ 255.0798; found 255.0808

\section{$N$-(Diallylcarbamoyl)-4-methylbenzenesulfonamide (6f)}

(25) One ${ }^{13} \mathrm{C}$ signal could not be resolved. 


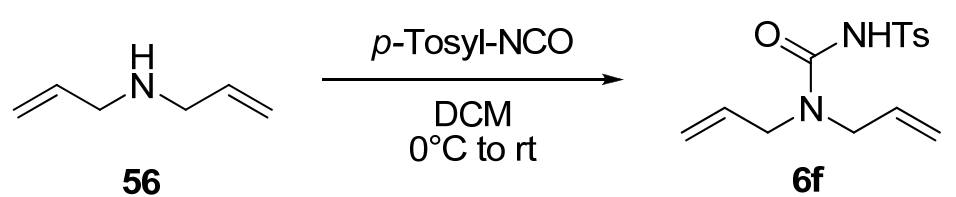

p-Tosylisocyanate $(1.0 \mathrm{~mL}, 4.1 \mathrm{mmol}, 1.02$ equiv) was added to a solution of diallylamine (56) $\left(0.31 \mathrm{~mL}, 4.0 \mathrm{mmol}, 1.0\right.$ equiv) in $\mathrm{DCM}(8.0 \mathrm{~mL})$ at $0^{\circ} \mathrm{C}$. The reaction mixture was allowed to warm to $\mathrm{rt}$ and stirred for $1 \mathrm{~h}$. The DCM was then evaporated under reduced pressure and ethyl acetate $(8 \mathrm{~mL})$ was added. The organic solution was washed with water $(8$ $\mathrm{mL})$. The aqueous layer was extracted with EtOAc $(8 \mathrm{~mL})$ and the combined organic layers washed with brine $(8 \mathrm{~mL})$, dried over $\mathrm{MgSO}_{4}$, filtered and concentrated under reduced pressure. Purification by column chromatography $\left(\mathrm{SiO}_{2}, \mathrm{DCM} / \mathrm{AcOEt} 9 / 1\right)$ afforded $\mathrm{N}$ (diallylcarbamoyl)-4-methylbenzenesulfonamide (6f) $(0.94 \mathrm{~g}, 3.2 \mathrm{mmol}, 80 \%$ yield) as a colorless oil.

$\mathrm{R}_{\mathrm{f}} 0.49(\mathrm{DCM} / \mathrm{EtOAc} 9 / 1) ;{ }^{1} \mathrm{H}$ NMR $\left(400 \mathrm{MHz}, \mathrm{CDCl}_{3}\right) \delta 7.90(\mathrm{~m}, 2 \mathrm{H}$, tosyl CH), $7.30(\mathrm{~m}$, $2 \mathrm{H}$, tosyl $\mathrm{CH}), 5.71\left(\mathrm{~m}, 2 \mathrm{H}, \mathrm{CH}_{2} \mathrm{CH}=\mathrm{CH}_{2}\right), 5.19\left(\mathrm{~d}, 2 \mathrm{H}, \mathrm{J}=10.3 \mathrm{~Hz}, \mathrm{CH}_{2} \mathrm{CH}=\mathrm{CH}_{2}\right), 5.14$ $\left(\mathrm{dd}, 2 \mathrm{H}, J=17.2,1.0 \mathrm{~Hz}, \mathrm{CH}_{2} \mathrm{CH}=\mathrm{CH}_{2}\right), 3.84\left(\mathrm{~d}, 4 \mathrm{H}, J=5.4 \mathrm{~Hz}, \mathrm{CH}_{2} \mathrm{CH}=\mathrm{CH}_{2}\right), 2.41$ (s, 3 $\mathrm{H}$, tosyl $\left.\mathrm{CH}_{3}\right) .{ }^{13} \mathrm{C} \mathrm{NMR}\left(101 \mathrm{MHz}, \mathrm{CDCl}_{3}\right) \delta 151.6,144.3,136.3,132.4,129.3,128.1$, 117.7, 48.9, 21.5. IR 3495 (w), 3495 (w), 3275 (w), 3085 (w), 3025 (w), $2987(w), 2926(w)$, $2871(\mathrm{w}), 2253$ (w), 1673 (s), 1646 (m), 1598 (w), 1459 (s), 1420 (m), 1384 (m), 1337 (m), 1308 (w), 1292 (w), 1232 (m), 1187 (m), 1164 (s), 1142 (m), 1122 (w), 1090 (m), 1020 (w), 995 (w), 910 (s), $891(\mathrm{~m}), 847(\mathrm{~m}), 814(\mathrm{~m}), 755(\mathrm{w}), 730$ (s), $706(\mathrm{~m}), 698(\mathrm{w}), 665$ (s), 649 $(\mathrm{m}), 603(\mathrm{w})$. HRMS (ESI) calculated for $\mathrm{C}_{14} \mathrm{H}_{19} \mathrm{~N}_{2} \mathrm{O}_{3} \mathrm{~S}^{+}\left(\mathrm{M}+\mathrm{H}^{+}\right)$295.1116; found 295.1104.

\section{2-Benzyl- $N$-tosylpent-4-enamide (6g)}

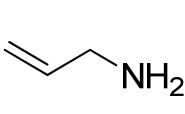

55
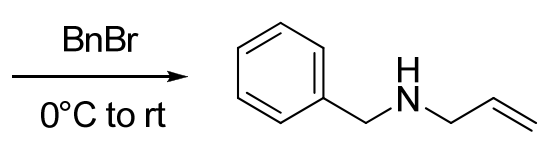

57

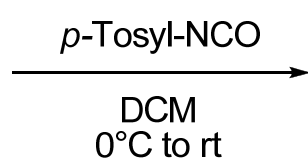

$0^{\circ} \mathrm{C}$ to rt<smiles></smiles>

$6 \mathrm{~g}$

Following a reported procedure ${ }^{[26]}$ benzyl bromide $(0.72 \mathrm{~mL}, 6.0 \mathrm{mmol}, 1.0$ equiv) was added dropwise to allyamine $(\mathbf{5 5})\left(2.7 \mathrm{~mL}, 36 \mathrm{mmol}, 6.0\right.$ equiv) at $0^{\circ} \mathrm{C}$. The mixture was allowed to warm to $\mathrm{rt}$ and stirred overnight. The reaction was quenched by adding $\mathrm{NaHCO}_{3}$ (6 mL, saturated solution). The aqueous layer was extracted with $\mathrm{Et}_{2} \mathrm{O}(3 \times 10 \mathrm{~mL})$. The combined organic layers were dried over $\mathrm{K}_{2} \mathrm{CO}_{3}$, filtered and concentrated under reduced pressure. Purification by column chromatography $\left(\mathrm{SiO}_{2}\right.$, Petroleum ether/AcOEt 8/1) afforded $N$-benzylprop-2-en-1-amine (57) (338 mg, $2.30 \mathrm{mmol}, 38 \%$ yield) as a colorless oil.

$p$-Tosylisocyanate $(0.56 \mathrm{~mL}, 2.3 \mathrm{mmol}, 1.0$ equiv) was added to a solution of $N$-benzylprop2-en-1-amine (57) (338 mg, $2.30 \mathrm{mmol}, 1.00$ equiv) in DCM $(5 \mathrm{~mL})$ at $0^{\circ} \mathrm{C}$. The reaction mixture was allowed to warm to rt and stirred for $1 \mathrm{~h}$. The DCM was then evaporated under reduced pressure and ethyl acetate $(5 \mathrm{~mL})$ was added. The organic solution was washed with water $(5 \mathrm{~mL})$. The aqueous layer was extracted with EtOAc $(5 \mathrm{~mL})$ and the combined organic layers washed with brine $(8 \mathrm{~mL})$, dried over $\mathrm{MgSO}_{4}$, filtered and concentrated under reduced

[26] D. F. Harvey, D. M. Sigano, J. Org. Chem. 1996, 61, 2268. 
pressure. Purification by column chromatography $\left(\mathrm{SiO}_{2}, \mathrm{DCM} / \mathrm{AcOEt} / \mathrm{AcOH}\right.$ 90/10/2) afforded 2-benzyl- $\mathrm{N}$-tosylpent-4-enamide (6g) (0.555 g, $1.62 \mathrm{mmol}, 70 \%$ yield) as a colorless amorphous solid.

$\mathrm{R}_{\mathrm{f}} 0.43(\mathrm{DCM} / \mathrm{AcOEt} 9 / 1) ;{ }^{1} \mathrm{H} \mathrm{NMR}\left(400 \mathrm{MHz}, \mathrm{CDCl}_{3}\right) \delta 7.88(\mathrm{~m}, 2 \mathrm{H}, J=8.0 \mathrm{~Hz}$, tosyl $\mathrm{CH}), 7.36-7.27\left(\mathrm{~m}, 5 \mathrm{H}, \mathrm{CH}_{2} \mathrm{Ph}\right), 7.17(\mathrm{~m}, 2 \mathrm{H}$, tosyl $\mathrm{CH}), 5.71\left(\mathrm{~m}, 1 \mathrm{H}, \mathrm{CH}_{2} \mathrm{CH}=\mathrm{CH}_{2}\right), 5.24$ $\left(\mathrm{d}, 1 \mathrm{H}, J=10.2 \mathrm{~Hz}, \mathrm{CH}_{2} \mathrm{CH}=\mathrm{CH}_{2}\right), 5.17\left(\mathrm{dd}, 1 \mathrm{H}, J=17.2,0.7 \mathrm{~Hz}, \mathrm{CH}_{2} \mathrm{CH}=\mathrm{CH}_{2}\right), 4.43$ (s, 2 $\left.\mathrm{H}, \mathrm{CH}_{2} \mathrm{Ph}\right), 3.81\left(\mathrm{~d}, 2 \mathrm{H}, \mathrm{J}=1.2 \mathrm{~Hz}, \mathrm{CH}_{2} \mathrm{CH}=\mathrm{CH}_{2}\right), 2.43\left(\mathrm{~m}, 3 \mathrm{H}\right.$, tosyl $\left.\mathrm{CH}_{3}\right) ;{ }^{13} \mathrm{C}$ NMR $(101$ $\left.\mathrm{MHz}, \mathrm{CDCl}_{3}\right) \delta 152.1,144.3,136.3,132.3,129.4,128.8,128.2,127.8,127.5,126.4,117.9$, 49.9, 49.1, 21.6; IR 3281 (w), 3256 (w), 3065 (w), 3032 (w), 2927 (w), 2854 (w), $2364(w)$, 1746 (w), 1739 (w), 1730 (w), 1677 (m), 1670 (m), 1598 (w), 1573 (w), 1495 (m), 1464 (s), 1453 (s), 1386 (w), 1338 (m), 1308 (w), 1293 (w), 1230 (m), 1187 (w), $1164(\mathrm{~s}), 1134$ (w), $1086(\mathrm{~m}), 1067(\mathrm{w}), 1032(\mathrm{w}), 1021(\mathrm{w}), 996(\mathrm{w}), 912(\mathrm{w}), 893(\mathrm{w}), 857(\mathrm{~m}), 816(\mathrm{w}), 743$ (m), $738(\mathrm{~m}), 702(\mathrm{~m}), 665$ (s); HRMS (ESI) calculated for $\mathrm{C}_{18} \mathrm{H}_{21} \mathrm{~N}_{2} \mathrm{O}_{3} \mathrm{~S}^{+}\left(\mathrm{M}+\mathrm{H}^{+}\right)$345.1273; found 345.1265 .

\section{Optimization of the Reaction}

\section{General procedure for reaction optimization:}

Tosyl amide 1a (18 $\mathrm{mg}, 0.071 \mathrm{mmol}, 1.0$ equiv), the catalyst ( $0.014 \mathrm{mmol}, 0.20$ equiv), benziodoxolone reagent $(0.084 \mathrm{mmol}, 1.2$ equiv) and the additive (when applicable) were dissolved in the solvent $(1.75 \mathrm{~mL})$. The mixture was stirred overnight at room temperature, before being filtered through a short celite plug. The latter was washed with $\mathrm{CHCl}_{3}(5 \times 2$ $\mathrm{mL}$ ) and the resulting solution was concentrated in vacuo. The residue was then dissolved in $\mathrm{CDCl}_{3}$ (ca $1 \mathrm{~mL}$ ) and a standard hexamethyldisiloxane solution $(0.1 \mathrm{M}, 0.088 \mathrm{~mL})$ was added. Yield was determined by ${ }^{1} \mathrm{H}-\mathrm{NMR}$, based on the following calibration.

\section{${ }^{1}$ H-NMR Quantification}

The $0.1 \mathrm{M}$ standard solution was prepared by dissolving hexamethyldisiloxane $(0.10 \mathrm{~mL}, 4.7$ $\mathrm{mmol})$ in $\mathrm{CDCl}_{3}(4.6 \mathrm{~mL})$.

1-Tosyl-5-(3-(triisopropylsilyl)prop-2-ynyl)pyrrolidin-2-one (3a) $(28 \mathrm{mg}, 0.065 \mathrm{mmol}$ ) was dissolved in $\mathrm{CDCl}_{3}$ (ca $0.5 \mathrm{~mL}$ ) (solution $\mathrm{A}$ ). Different volumes of $0.1 \mathrm{M}$ standard solution were added to solution A: $0.050 \mathrm{~mL}$ (solution B); $0.100 \mathrm{~mL}$ (solution C); $0.150 \mathrm{~mL}$ (solution D); $0.200 \mathrm{~mL}$ (solution E), $0.250 \mathrm{~mL}$ (solution F), $0.300 \mathrm{~mL}$ (solution G). ${ }^{1} \mathrm{H}$ NMR spectra were acquired for solution A-G. For each ${ }^{1} \mathrm{H}$ NMR spectrum, the ratio between the integrals of the signal at $\delta 2.91\left(\mathrm{dd}, 1 \mathrm{H}, J=17.1,6.5 \mathrm{~Hz}, \mathrm{CH}_{2} \mathrm{C} \equiv \mathrm{C}\right)$ of $\mathbf{3 a}$ and the signal at $\delta 0.06(\mathrm{~s}, 1$ $\mathrm{H}, \mathrm{TMS}$ ) of hexamethyldisiloxane was calculated. These observed ratios by integration of the ${ }^{1} \mathrm{H}-\mathrm{NMR}$ peaks and the ratios ( $\mathrm{mmol} \mathbf{3 a} / \mathrm{mmol}$ hexamethyldisiloxane) were used as the axis of the calibration graph. 


\section{Calibration Curve}

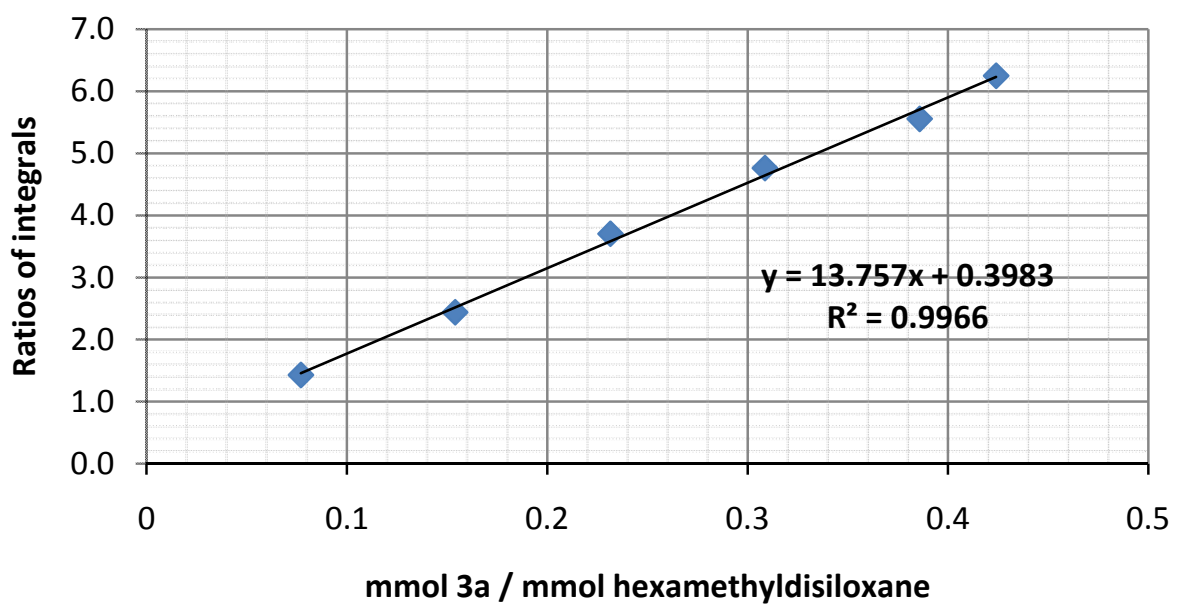

Detailed results for the optimization studies 
Table S1: Solvent screening for the reaction of $1 \mathbf{a}$ with $\mathbf{2 a}$.

\begin{tabular}{|c|c|c|c|c|c|}
\hline Entry & Solvent & Yield (\%) & Entry & Solvent & Yield (\%) \\
\hline 1 & $\mathrm{CH}_{2} \mathrm{Cl}_{2}$ & $44(33)^{b}$ & 10 & THF & - \\
\hline 2 & $\mathrm{CHCl}_{3}$ & 57 & 11 & $\mathrm{PhCH}_{3}$ & $<5$ \\
\hline 3 & DCE & 43 & 12 & $\mathrm{MeOH}$ & 31 \\
\hline 4 & $\mathrm{CH}_{2} \mathrm{Cl}_{2} /$ Hexane $(10 \%)$ & 15 & 13 & $\mathrm{EtOH}$ & 34 \\
\hline 5 & Acetone & - & 14 & ${ }^{\mathrm{i}} \mathrm{PrOH}$ & 30 \\
\hline 6 & Acetonitrile & - & 15 & $\mathrm{CHCl}_{3} / \mathrm{EtOH}(1 / 1)$ & 43 \\
\hline 7 & $\mathrm{AcOH}$ & - & 16 & $\mathrm{CHCl}_{3} / \mathrm{EtOH}(9 / 1)$ & 52 \\
\hline 8 & DMSO & - & 17 & $\mathrm{CHCl}_{3} / \mathrm{AcOH}(9 / 1)$ & 31 \\
\hline 9 & DMF & - & 18 & $\mathrm{CHCl}_{3} / \mathrm{H}_{2} \mathrm{O}(1 / 1)$ & 10 \\
\hline
\end{tabular}

Table S2: Catalyst screening for the reaction of 1a with 2a.

\begin{tabular}{ccccc}
\hline Entry & Catalyst (20 mol \%) & Additive & Solvent & Yield (\%) \\
\hline 1 & $\mathrm{Pd}(\mathrm{hfacac})_{2}$ & - & $\mathrm{CHCl}_{3}$ & 57 \\
2 & $\mathrm{Pd}(\mathrm{hfacac})_{2}$ & $\mathrm{TFA}(1.2$ equiv $)$ & $\mathrm{CHCl}_{3}$ & 22 \\
3 & $\mathrm{Pd}(\mathrm{tfa})_{2}$ & - & $\mathrm{CHCl}_{3}$ & 10 \\
4 & $\mathrm{Pd}(\mathrm{OAc})_{2}$ & - & $\mathrm{CHCl}_{3}$ & $<5$ \\
5 & $\mathrm{Pd}(\mathrm{acac})_{2}$ & - & $\mathrm{CHCl}_{3}$ & 15 \\
6 & $\mathrm{PdCl}$ & $\mathrm{CHCl}_{3}$ & $19(\mathrm{conv} .: 54 \%)$ \\
7 & $\mathrm{PdCl}\left(\mathrm{MeCN}_{2}\right.$ & - & $\mathrm{CHCl}_{3}$ & 31 \\
8 & $\mathrm{Pd}\left(\mathrm{dba}_{2}\right.$ & - & $\mathrm{CHCl}_{3}$ & - \\
9 & $\mathrm{Pd}\left(\mathrm{MeCN}_{4}(\mathrm{BF})_{2}\right.$ & - & $\mathrm{CHCl}_{3}$ & $<5$ \\
10 & $\mathrm{Catalyst}_{2}$ & - & $\mathrm{CHCl}_{3}$ & $21(\mathrm{conv} .: 56 \%)$ \\
11 & $\mathrm{PdCl}_{2}$ & - & $\mathrm{EtOH}^{2}$ & 57 \\
12 & $\mathrm{PdCl}_{2}\left(\mathrm{PPh}_{3}\right)_{2}$ & - & $\mathrm{EtOH}^{2}$ & - \\
\hline
\end{tabular}

Reaction conditions: $0.069 \mathrm{mmol}$ 1a, $0.014 \mathrm{mmol}$ catalyst, $0.084 \mathrm{mmol}$ TIPS-EBX (2a), 0.084 mmol additive in $1.75 \mathrm{~mL}$ solvent, $15 \mathrm{~h}$, rt. Yield was determined via ${ }^{1} \mathrm{H}$ NMR. 
Table S3: Optimization of the $\mathrm{Pd}(\mathrm{hfacac})_{2} / \mathrm{CHCl}_{3}$ conditions

\begin{tabular}{|c|c|c|}
\hline Entry & Additive (1.2 equiv.) & Yield (\%) \\
\hline 1 & TFA & 22 \\
\hline 2 & $\mathrm{CF}_{3} \mathrm{CH}_{2} \mathrm{OH}$ & 55 \\
\hline 3 & $\left(\mathrm{CF}_{3}\right)_{2} \mathrm{CHOH}$ & 47 \\
\hline 4 & 2,5-ditertbutyl pyridine & 70 \\
\hline 5 & pyridine & - \\
\hline 6 & $\mathrm{LiCl}$ & 55 \\
\hline 7 & $\mathrm{CuI}$ & $<10$ \\
\hline $\begin{array}{l}\text { Reacti } \\
\text { mmol } \\
0.084 \\
\text { rt. Yie }\end{array}$ & $\begin{array}{l}\text { conditions: } 0.069 \mathrm{mmol} \\
\text { hfacac })_{2}, 0.084 \mathrm{mmol} \mathrm{TIP} \\
\text { ol additive in } 1.75 \mathrm{~mL} \mathrm{~s} \\
\text { vas determined via }{ }^{1} \mathrm{H} \mathrm{NM}\end{array}$ & $\begin{array}{l}\text { a, } 0.0028 \\
\text { EBX }(\mathbf{2 a}), \\
\text { vent, } 15 \mathrm{~h},\end{array}$ \\
\hline
\end{tabular}

Table S3: Optimization of the $\mathrm{PdCl}_{2} / \mathrm{Alcohol}$ conditions (effect of additives and solvents)

\begin{tabular}{ccccc}
\hline Entry & Additive & n. equiv. & Solvent & Yield (\%) \\
\hline 1 & $\mathrm{Lil}$ & 1.2 & $\mathrm{EtOH}$ & 11 \\
2 & $\mathrm{LiBr}$ & 1.2 & $\mathrm{EtOH}$ & 20 \\
3 & $\mathrm{LiCl}$ & 1.2 & $\mathrm{EtOH}$ & 76 \\
$\mathbf{4}$ & $\mathbf{L i C l}$ & $\mathbf{1 . 2}$ & $\mathbf{M e O H}$ & $\mathbf{9 3}$ \\
5 & $\mathrm{LiCl}$ & 1.2 & $\mathrm{n}-\mathrm{PrOH}$ & 80 \\
6 & $\mathrm{LiCl}$ & 1.2 & $\mathrm{i}-\mathrm{PrOH}$ & 70 \\
$\mathbf{7}$ & $\mathbf{L i C l}$ & $\mathbf{1 0}$ & $\mathbf{E t O H}$ & $\mathbf{9 3}$ \\
8 & $\mathrm{KCl}$ & 1.2 & $\mathrm{EtOH}$ & 64 \\
9 & $\mathrm{Bu}_{4} \mathrm{NCl}$ & 1.2 & $\mathrm{EtOH}$ & 48 \\
10 & $\mathrm{LiBF}_{4}$ & 1.2 & $\mathrm{EtOH}$ & 20 \\
11 & $\mathrm{CuI}_{12}^{2,5-d i t e r t b u t y l ~ p y r i d i n e}$ & 1.2 & $\mathrm{EtOH}$ & 62 \\
13 & $\mathrm{~K}_{2} \mathrm{CO}_{3}$ & 1.2 & $\mathrm{EtOH}$ & - \\
14 & $\mathrm{LiCl} / 2,5$-ditertbutyl pyridine & 1.2 & $\mathrm{EtOH}$ & 62 \\
\hline
\end{tabular}

Reaction conditions: $0.069 \mathrm{mmol} 1 \mathrm{a}, 0.014 \mathrm{mmol} \mathrm{PdCl}_{2}, 0.084 \mathrm{mmol}$ TIPSEBX (2a), $0.084 \mathrm{mmol}$ additive in $1.75 \mathrm{~mL}$ solvent, $15 \mathrm{~h}$, rt. Yield was determined via ${ }^{1} \mathrm{H}$ NMR.

Table S4: Application of the optimized conditions (Upscaling/Isolation)

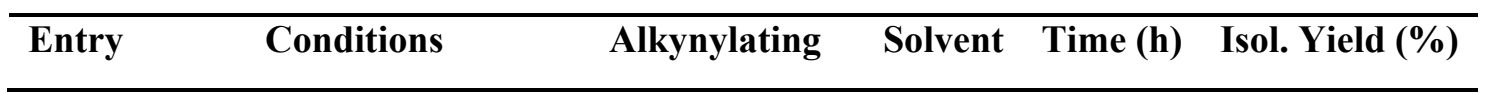




\begin{tabular}{|c|c|c|c|c|c|}
\hline \multicolumn{6}{|c|}{ Reagent } \\
\hline 1 & $\mathrm{PdCl}_{2} / \mathrm{LiCl}$ (1.2 equiv) & TIPS-EBX & $\mathrm{MeOH}$ & 1 & 77 \\
\hline 2 & $\mathrm{PdCl}_{2} / \mathrm{LiCl}$ (3.6 equiv) & TIPS-EBX & $\mathrm{MeOH}$ & 1 & 81 \\
\hline 3 & $\mathrm{PdCl}_{2} / \mathrm{LiCl}$ (1.2 equiv) & TIPS-EBX & EtOH & 3.5 & 75 \\
\hline 4 & $\mathrm{PdCl}_{2} / \mathbf{L i C l}$ (3.6 equiv) & TIPS-EBX & EtOH & 5 & 87 \\
\hline 5 & $\begin{array}{c}\operatorname{Pd}(\text { hfacac })_{2} / \\
\text { ditertbutyl Py }(1.2 \text { equiv })\end{array}$ & TIPS-EBX & $\mathrm{CHCl}_{3}$ & 15 & 55 \\
\hline 6 & $\mathrm{PdCl}_{2} / \mathrm{LiCl}$ (3.6 equiv) & TMS-EBX & $\mathrm{EtOH}$ & 5 & 23 \\
\hline 7 & $\mathrm{PdCl}_{2} / \mathrm{LiCl}$ (3.6 equiv) & $\mathrm{TIPS}=\mathrm{IPh}^{+} \mathrm{OTf}$ & $\mathrm{EtOH}$ & 5 & $<5$ \\
\hline $8^{a}$ & $\mathrm{PdCl}_{2} / \mathrm{LiCl}$ (3.6 equiv) & $\mathrm{TIPS}=\mathrm{I}$ & $\mathrm{EtOH}$ & 5 & $<5$ \\
\hline $9^{b}$ & $\mathrm{PdCl}_{2} / \mathrm{LiCl}$ (3.6 equiv) & $\mathrm{TIPS}=\mathrm{Br}$ & $\mathrm{EtOH}$ & 5 & - \\
\hline
\end{tabular}

Isolated yield using $0.40 \mathrm{mmol}$ 1a, $0.040 \mathrm{mmol}$ catalyst, $0.48 \mathrm{mmol}$ TIPS-EBX (2a), additive in 10 $\mathrm{mL}$ solvent. ${ }^{a}$ Reaction performed using $0.069 \mathrm{mmol} \mathbf{1 a}, 0.014 \mathrm{mmol} \mathrm{PdCl}_{2}, 0.25 \mathrm{mmol} \mathrm{LiCl}, 0.084$ mmol CuI, 0.084 mmol TIPS-EBX (2a), $1.75 \mathrm{~mL}$ solvent, $15 \mathrm{~h}$, rt. No conversion was observed with and without CuI. ${ }^{b}$ Reaction performed using $0.069 \mathrm{mmol} 1 \mathrm{a}, 0.014 \mathrm{mmol} \mathrm{PdCl}_{2}, 0.25 \mathrm{mmol} \mathrm{LiCl}$, $0.084 \mathrm{mmol} \mathrm{CuI}, 0.084 \mathrm{mmol}$ TIPS-EBX (2a), $1.75 \mathrm{~mL}$ solvent, $15 \mathrm{~h}$, rt. No conversion was observed with and without CuI.

\section{Scope of the Reaction}

General Procedure for the intramolecular aminoalkynylation:

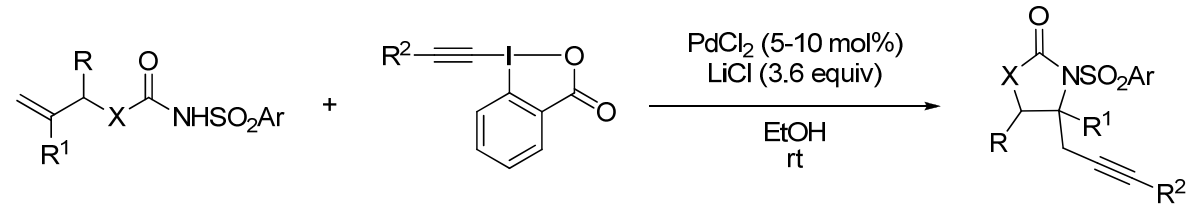

The tosyl amide $(0.40 \mathrm{mmol}, 1.0$ equiv) was added to a solution of $\mathrm{LiCl}(61.0 \mathrm{mg}, 1.44$ mmol, 3.60 equiv) in $\mathrm{EtOH}(10 \mathrm{~mL})$, followed by $\mathrm{PdCl}_{2}$ (7.1 mg, $0.040 \mathrm{mmol}, 0.10$ equiv) and benziodoxolone reagent $(0.480 \mathrm{mmol}, 1.20$ equiv). The mixture was stirred for $2-5 \mathrm{~h}$ at room temperature. EtOH was then removed under reduced pressure and the residue was diluted with $20 \mathrm{~mL} \mathrm{Et}_{2} \mathrm{O}$. The organic solution was washed with a saturated solution of $\mathrm{Na}_{2} \mathrm{CO}_{3}(20 \mathrm{~mL})$. The aqueous layer was extracted with $\mathrm{Et}_{2} \mathrm{O}(3 \times 20 \mathrm{~mL})$ and the combined organic layers were dried over $\mathrm{MgSO}_{4}$, filtered and concentrated in vacuo. The resulting crude product was purified by column chromatography.

\section{1-Tosyl-5-(3-(triisopropylsilyl)prop-2-ynyl)pyrrolidin-2-one (3a)}

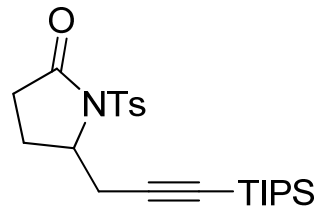

Column chromatography $\left(\mathrm{SiO}_{2}, \mathrm{PET} /\right.$ EtOAc $95 / 5$ to $\left.90 / 10\right)$ afforded product 3a (152 $\mathrm{mg}, 0.350 \mathrm{mmol}, 88 \%$ yield) as a yellow solid.

Large scale reaction: Tosyl amide $1 \mathrm{a}$ (1.93 g, $7.61 \mathrm{mmol}, 1.00$ equiv) was added to a solution of $\mathrm{LiCl}(1.21 \mathrm{~g}, 27.4 \mathrm{mmol}, 3.60$ equiv) in $\mathrm{EtOH}$ 
(100 mL), followed by $\mathrm{PdCl}_{2}$ (71 mg, $0.40 \mathrm{mmol}, 0.052$ equiv) and TIPS-EBX (2a) (3.91 g, $9.12 \mathrm{mmol}, 1.20$ equiv). The mixture was stirred for $4 \mathrm{~h}$ at room temperature. EtOH was then removed under reduced pressure and the residue was diluted with $100 \mathrm{~mL} \mathrm{Et}_{2} \mathrm{O}$. The organic solution was washed with a saturated solution of $\mathrm{Na}_{2} \mathrm{CO}_{3}(100 \mathrm{~mL})$. The aqueous layer was extracted with $\mathrm{Et}_{2} \mathrm{O}(3 \times 100 \mathrm{~mL})$ and the combined organic layers were dried over $\mathrm{MgSO}_{4}$, filtered and concentrated in vacuo. Column chromatography $\left(\mathrm{SiO}_{2}, \mathrm{PET} / \mathrm{EtOAc} 95 / 5\right.$ to 90/10) afforded product 3a (2.50 g, $5.77 \mathrm{mmol}, 76 \%$ yield) as a yellow solid.

$\mathrm{R}_{\mathrm{f}} 0.59$ (PET/EtOAc 4/1); ${ }^{1} \mathrm{H}$ NMR (400 MHz, $\left.\mathrm{CDCl}_{3}\right) \delta 7.97(\mathrm{~m}, 2 \mathrm{H}$, tosyl CH), 7.31 (d, 2 $\mathrm{H}, J=8.1 \mathrm{~Hz}$, tosyl $\mathrm{CH}), 4.53(\mathrm{~m}, 1 \mathrm{H}, \mathrm{NCH}), 2.91$ (dd, $\left.1 \mathrm{H}, J=17.1,6.5 \mathrm{~Hz}, \mathrm{CH}_{2} \mathrm{C} \equiv \mathrm{C}\right)$, 2.83-2.68 (m, $2 \mathrm{H}, \mathrm{CH}_{2} \mathrm{C} \equiv \mathrm{C}$ and $\left.\mathrm{CH}_{2} \mathrm{C}=\mathrm{O}\right), 2.42\left(\mathrm{~s}, 3 \mathrm{H}\right.$, tosyl $\left.\mathrm{CH}_{3}\right), 2.42-2.05(\mathrm{~m}, 3 \mathrm{H}$, $\mathrm{CH}_{2} \mathrm{CH}_{2} \mathrm{C}=\mathrm{O}$ ), 1.19-0.78 (m, $21 \mathrm{H}$, TIPS); ${ }^{13} \mathrm{C}$ NMR $\left(101 \mathrm{MHz}, \mathrm{CDCl}_{3}\right) \delta 173.5,145.0$, 135.7, 129.5, 128.5, 102.6, 84.5, 58.1, 31.0, 26.5, 23.6, 21.7, 18.5, 11.2; IR 2943 (m), 2891 (w), $2865(\mathrm{~m}), 2257(\mathrm{w}), 2175(\mathrm{w}), 1738(\mathrm{~m}), 1686(\mathrm{w}), 1598(\mathrm{w}), 1495(\mathrm{w}), 1463(\mathrm{~m}), 1431$ (w), $1362(\mathrm{~m}), 1307(\mathrm{w}), 1292(\mathrm{w}), 1272(\mathrm{w}), 1220(\mathrm{w}), 1187(\mathrm{~m}), 1170(\mathrm{~s}), 1111(\mathrm{~m}), 1090$ (m), $1074(\mathrm{w}), 1045(\mathrm{w}), 1031(\mathrm{w}), 1014(\mathrm{w}), 997(\mathrm{w}), 955(\mathrm{~m}), 912(\mathrm{~m}), 884(\mathrm{~m}), 814(\mathrm{w})$, 800 (w), 772 (w), $766(\mathrm{w}), 735$ (s), 705 (w), 678 (s), $642(\mathrm{~m}), 634$ (s), $626(\mathrm{w}), 617$ (w); Melting Point: $68.8-71.5^{\circ} \mathrm{C}$; HRMS (ESI) calcd for $\mathrm{C}_{23} \mathrm{H}_{36} \mathrm{NO}_{3} \mathrm{SSi}^{+}\left(\mathrm{M}+\mathrm{H}^{+}\right)$434.2185; found: 434.2183 .

\section{1-Tosyl-5-(3-(trimethylsilyl)prop-2-ynyl)pyrrolidin-2-one (4)}

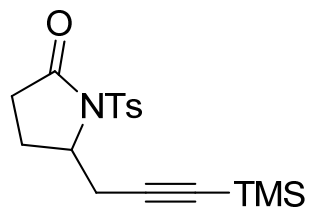

Column chromatography $\left(\mathrm{SiO}_{2}\right.$, PET/EtOAc 85/15) afforded product 4 (33 mg, $0.094 \mathrm{mmol}, 24 \%$ yield) as a yellow amorphous solid.

$\mathrm{R}_{\mathrm{f}} 0.41\left(\mathrm{PET} /\right.$ EtOAc 4/1); ${ }^{1} \mathrm{H}$ NMR (400 MHz, $\left.\mathrm{CDCl}_{3}\right) \delta 7.96(\mathrm{~m}, 2 \mathrm{H}$, tosyl $\mathrm{CH}), 7.31(\mathrm{~d}, 2 \mathrm{H}, J=8.2 \mathrm{~Hz}$, tosyl $\mathrm{CH}), 4.51(\mathrm{~m}, 1 \mathrm{H}, \mathrm{NCH}), 2.91$ (dd, $1 \mathrm{H}, J=17.2,6.3 \mathrm{~Hz}, \mathrm{CH}_{2} \mathrm{C} \equiv \mathrm{C}$ ), 2.77-2.60 (m, $1 \mathrm{H}, \mathrm{CH}_{2} \mathrm{CO}$ ), 2.64 (dd, $1 \mathrm{H}, J=17.2,2.9$ $\left.\mathrm{Hz}, \mathrm{CH}_{2} \mathrm{C} \equiv \mathrm{C}\right), 2.45-2.23\left(\mathrm{~m}, 2 \mathrm{H}, \mathrm{COCH}_{2} \mathrm{CH}_{2}\right), 2.42\left(\mathrm{~s}, 3 \mathrm{H}\right.$, tosyl $\left.\mathrm{CH}_{3}\right), 2.07(\mathrm{~m}, 1 \mathrm{H}$, $\left.\mathrm{COCH}_{2} \mathrm{CH}_{2}\right), 0.01(\mathrm{~m}, 9 \mathrm{H}, \mathrm{TMS}) ;{ }^{13} \mathrm{C} \mathrm{NMR}\left(101 \mathrm{MHz}, \mathrm{CDCl}_{3}\right) \delta 173.5,144.9,135.6$, 129.4, 128.5, 101.1, 88.6, 57.9, 31.0, 26.5, 23.8, 21.6, -0.4; IR 2960 (w), $2924(\mathrm{w}), 2258(\mathrm{w})$, 2178 (w), 1913 (w), 1737 (s), 1653 (w), 1598 (w), 1494 (w), 1457 (w), 1410 (w), 1360 (s), 1309 (w), 1291 (w), 1251 (m), 1221 (m), 1188 (m), 1168 (s), $1111(\mathrm{~s}), 1091(\mathrm{~m}), 1071(\mathrm{w})$, 1044 (w), 1015 (w), 955 (m), 912 (m), 845 (s), 815 (m), 763 (m), 733 (s), 705 (m), 676 (s), $646(\mathrm{~m}), 626(\mathrm{w}), 608(\mathrm{~m})$; HRMS (ESI) calcd for $\mathrm{C}_{17} \mathrm{H}_{24} \mathrm{NO}_{3} \mathrm{SSi}^{+}[\mathrm{M}+\mathrm{H}]^{+}$350.1241; found 350.1245 .

\section{5-(3-Phenylprop-2-ynyl)-1-tosylpyrrolidin-2-one (5)}

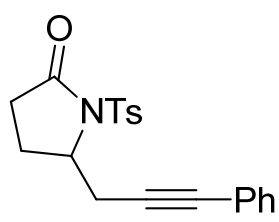

Column chromatography $\left(\mathrm{SiO}_{2}, \mathrm{PET} / \mathrm{EtOAc} 95 / 5\right.$ to $\left.90 / 10\right)$ afforded product 5 (83 $\mathrm{mg}, 0.23 \mathrm{mmol}, 58 \%$ yield; $95 \%$ pure) as a yellow amorphous solid.

$\mathrm{R}_{\mathrm{f}} 0.34(\mathrm{PET} / \mathrm{EtOAc}=4 / 1) ;{ }^{1} \mathrm{H}$ NMR $\left(400 \mathrm{MHz}, \mathrm{CDCl}_{3}\right) \delta 8.03(\mathrm{~d}, 2 \mathrm{H}, J$ $=8.3 \mathrm{~Hz}$, tosyl $\mathrm{CH}), 7.37-7.19(\mathrm{~m}, 5 \mathrm{H}, \mathrm{Ph}), 7.15(\mathrm{~m}, 2 \mathrm{H}$, tosyl $\mathrm{CH}), 4.65(\mathrm{~m}, 1 \mathrm{H}, \mathrm{NCH})$, $3.17\left(\mathrm{dd}, 1 \mathrm{H}, J=17.2,6.3 \mathrm{~Hz}, \mathrm{CH}_{2} \mathrm{C} \equiv \mathrm{C}\right), 2.92-2.67\left(\mathrm{~m}, 2 \mathrm{H}, \mathrm{CH}_{2} \mathrm{C} \equiv \mathrm{C}\right.$ and $\left.\mathrm{CH}_{2} \mathrm{C}=\mathrm{O}\right), 2.49-$ $2.30\left(\mathrm{~m}, 2 \mathrm{H}, \mathrm{CH}_{2} \mathrm{CH}_{2} \mathrm{C}=\mathrm{O}\right), 2.36\left(\mathrm{~s}, 3 \mathrm{H}\right.$, tosyl $\left.\mathrm{CH}_{3}\right), 2.15\left(\mathrm{~m}, 1 \mathrm{H}, \mathrm{CH}_{2} \mathrm{CH}_{2} \mathrm{C}=\mathrm{O}\right) .{ }^{13} \mathrm{C} \mathrm{NMR}$ $\left(101 \mathrm{MHz}, \mathrm{CDCl}_{3}\right) \delta 173.7,145.0,135.5,131.4,129.4,128.5,128.1,128.1,122.6,84.2,83.9$, 
58.1, 31.0, 26.2, 24.1, 21.6; IR 3058 (w), 2992 (w), 2926 (w), 2362 (w), $2338(\mathrm{w}), 1735$ (s), 1735 (s), 1597 (m), 1575 (w), $1541(\mathrm{w}), 1513$ (w), 1491 (w), 1464 (w), 1442 (w), 1356 (m), 1295 (w), 1268 (w), 1222 (m), 1168 (s), 1109 (m), 1089 (m), 1062 (w), 1042 (w), 1017 (w), $956(\mathrm{~m}), 913$ (m), $865(\mathrm{w}), 847$ (w), 815 (m), $761(\mathrm{~m}), 731(\mathrm{~m}), 710(\mathrm{w}), 672$ (s), $610(\mathrm{~m})$; HRMS (ESI) calcd for $\mathrm{C}_{20} \mathrm{H}_{20} \mathrm{NO}_{3} \mathrm{~S}^{+}\left(\mathrm{M}+\mathrm{H}^{+}\right)$354.1164; found: 354.1159 .

\section{1-(4-Methoxyphenylsulfonyl)-5-(3-(triisopropylsilyl)prop-2-ynyl)pyrrolidin-2-one (3b)}

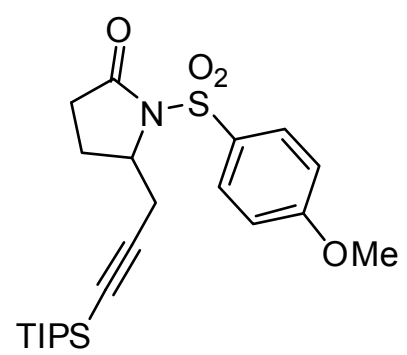

Column chromatography $\left(\mathrm{SiO}_{2}, \mathrm{PET} /\right.$ EtOAc $\left.92 / 8\right)$ afforded product 3b (144 $\mathrm{mg}, 0.320 \mathrm{mmol}, 80 \%$ yield) as a yellow solid.

$\mathrm{R}_{\mathrm{f}} 0.59$ (PET/EtOAc 4/1); ${ }^{1} \mathrm{H}$ NMR (400 MHz, $\left.\mathrm{CDCl}_{3}\right) \delta 8.02(\mathrm{~m}, 2$ $\mathrm{H}, \quad p$-OMe-phenylsulfonyl $\mathrm{CH}), 6.97(\mathrm{~m}, 2 \mathrm{H}, \quad p$-OMephenylsulfonyl $\mathrm{CH}), 4.52(\mathrm{~m}, 1 \mathrm{H}, \mathrm{NCH}), 3.86\left(\mathrm{~s}, 3 \mathrm{H}, \mathrm{OCH}_{3}\right), 2.91$ $\left(\mathrm{dd}, 1 \mathrm{H}, J=17.1,6.5 \mathrm{~Hz}, \mathrm{CH}_{2} \mathrm{C} \equiv \mathrm{C}\right), 2.83-2.66\left(\mathrm{~m}, 2 \mathrm{H}, \mathrm{CH}_{2} \mathrm{C} \equiv \mathrm{C}\right.$ and $\mathrm{COCH}_{2} \mathrm{CH}_{2}$ ), 2.45-2.23 (m, $2 \mathrm{H}, \mathrm{COCH}_{2} \mathrm{CH}_{2}$ ), 2.13 (m, $1 \mathrm{H}, \mathrm{COCH}_{2} \mathrm{CH}_{2}$ ), 1.02-0.91 (m, $21 \mathrm{H}, \mathrm{TIPS}) ;{ }^{13} \mathrm{C} \mathrm{NMR}\left(101 \mathrm{MHz}, \mathrm{CDCl}_{3}\right) \delta 173.4,163.9,130.8,130.0,114.0,102.6,84.5$, 58.1, 55.6, 30.9, 26.4, 23.5, 18.5, 11.1; IR 2958 (w), 2944 (w), $2865(\mathrm{w}), 2361(\mathrm{w}), 2343(\mathrm{w})$, $2174(\mathrm{w}), 1738(\mathrm{~m}), 1596(\mathrm{~m}), 1580(\mathrm{w}), 1499(\mathrm{~m}), 1463(\mathrm{w}), 1416(\mathrm{w}), 1362(\mathrm{~m}), 1338(\mathrm{w})$, 1312 (w), 1264 (m), 1222 (m), 1197 (m), 1185 (m), 1164 (s), 1112 (m), 1093 (m), 1070 (w), 1045 (w), $1029(\mathrm{~m}), 998(\mathrm{w}), 955(\mathrm{~m}), 930(\mathrm{w}), 911(\mathrm{w}), 884(\mathrm{w}), 834(\mathrm{~m}), 805(\mathrm{~m}), 784(\mathrm{w})$, $770(\mathrm{w}), 762(\mathrm{w}), 736(\mathrm{~m}), 718(\mathrm{w}), 708(\mathrm{w}), 683(\mathrm{~s}), 671(\mathrm{~m}), 661(\mathrm{~m}), 650(\mathrm{w}), 631(\mathrm{~m})$, $616(\mathrm{~m})$; Melting point: $69.5-71.8^{\circ} \mathrm{C}$; HRMS (ESI) calcd for $\mathrm{C}_{23} \mathrm{H}_{36} \mathrm{NO}_{4} \mathrm{SSi}^{+}\left(\mathrm{M}+\mathrm{H}^{+}\right)$ 450.2144; found: 450.2129 .

\section{1-(4-Nitrophenylsulfonyl)-5-(3-(triisopropylsilyl)prop-2-nyl)pyrrolidin-one (3c)}

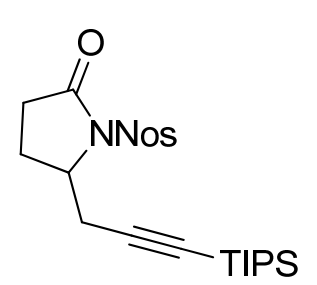

Column chromatography ( $\mathrm{SiO}_{2}, \mathrm{PET} /$ EtOAc $95 / 5$ to $\left.90 / 10\right)$ afforded product 3c (92 $\mathrm{mg}, 0.20 \mathrm{mmol}, 50 \%$ yield) as a yellowish solid.

$\mathrm{R}_{\mathrm{f}} 0.44(\mathrm{PET} / \mathrm{EtOAc} 4 / 1) ;{ }^{1} \mathrm{H}$ NMR $\left(400 \mathrm{MHz}, \mathrm{CDCl}_{3}\right) \delta 8.36(\mathrm{~m}, 2 \mathrm{H}$, Nosyl CH), 8.27 (m, 2 H, Nosyl CH), 4.58 (m, $1 \mathrm{H}, \mathrm{NCH}), 3.00$ (dd, $1 \mathrm{H}$, $\left.\mathrm{COCH}_{2} \mathrm{CH}_{2}\right), 2.52-2.31\left(\mathrm{~m}, 2 \mathrm{H}, \mathrm{COCH}_{2} \mathrm{CH}_{2}\right), 2.15\left(\mathrm{~m}, 1 \mathrm{H}, \mathrm{COCH}_{2} \mathrm{CH}_{2}\right), 1.07-0.87$ (m, 21 $\mathrm{H}$, TIPS); ${ }^{13} \mathrm{C}$ NMR $\left(101 \mathrm{MHz}, \mathrm{CDCl}_{3}\right) \delta 173.8,150.7,143.7,130.0,124.0,101.8,85.3,58.1$, 30.9, 26.5, 23.6, 18.4, 11.0; IR 3392 (w), 2944 (m), 2927 (w), $2866(\mathrm{w}), 2361(\mathrm{w}), 2143(\mathrm{w})$, 1749 (w), 1657 (w), 1656 (w), 1650 (w), $1536(w), 1463(w), 1433(w), 1415$ (w), 1403 (w), $1371(\mathrm{w}), 1370(\mathrm{w}), 1351(\mathrm{w}), 1317(\mathrm{w}), 1293(\mathrm{w}), 1248(\mathrm{w}), 1217(\mathrm{w}), 1178(\mathrm{~m}), 1141(\mathrm{w})$, $1111(\mathrm{w}), 1110(\mathrm{w}), 1089$ (w), $1068(\mathrm{w}), 1033(\mathrm{~m}), 1020(\mathrm{~m}), 1000(\mathrm{w}), 978(\mathrm{w}), 968(\mathrm{w})$, $958(\mathrm{w}), 937(\mathrm{w}), 925(\mathrm{w}), 900(\mathrm{w}), 884(\mathrm{~m}), 853(\mathrm{w}), 852(\mathrm{w}), 832(\mathrm{w}), 815(\mathrm{w}), 800(\mathrm{w})$, $792(\mathrm{w}), 784(\mathrm{w}), 728(\mathrm{~m}), 700(\mathrm{~m}), 675$ (s), 660 (s), 643 (m), 633 (s), 623 (s), 608 (m); Melting point: $106.5-108.5^{\circ} \mathrm{C}$; HRMS (ESI) calcd for $\mathrm{C}_{22} \mathrm{H}_{33} \mathrm{~N}_{2} \mathrm{O}_{5} \mathrm{SSi}^{+}\left(\mathrm{M}+\mathrm{H}^{+}\right) 465.1880$; found: 465.1873 .

\section{3,3-Dimethyl-1-tosyl-5-(3-(triisopropylsilyl)prop-2-ynyl)pyrrolidin-2-one (3d)}

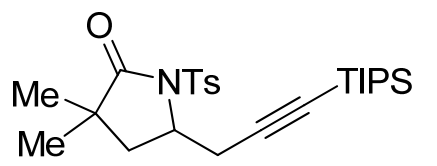

Column chromatography $\left(\mathrm{SiO}_{2}, \mathrm{PET} /\right.$ EtOAc $\left.95 / 5\right)$ afforded product 3d (154 mg, $0.334 \mathrm{mmol}, 84 \%$ yield) as a pale yellow 
solid.

$\mathrm{R}_{\mathrm{f}} 0.84(\mathrm{PET} / \mathrm{EtOAc} 4 / 1) ;{ }^{1} \mathrm{H}$ NMR $\left(400 \mathrm{MHz}, \mathrm{CDCl}_{3}\right) \delta 7.95(\mathrm{~d}, 2 \mathrm{H}, J=8.4 \mathrm{~Hz}$, tosyl CH), $7.30(\mathrm{~d}, 2 \mathrm{H}, J=8.1 \mathrm{~Hz}$, tosyl $\mathrm{CH}), 4.32(\mathrm{~m}, 1 \mathrm{H}, \mathrm{NCH}), 3.00(\mathrm{dd}, 1 \mathrm{H}, J=17.0,3.7 \mathrm{~Hz}$, $\left.\mathrm{CH}_{2} \mathrm{C} \equiv \mathrm{C}\right), 2.93\left(\mathrm{dd}, 1 \mathrm{H}, J=16.8,7.0 \mathrm{~Hz}, \mathrm{CH}_{2} \mathrm{C} \equiv \mathrm{C}\right), 2.41\left(\mathrm{~s}, 3 \mathrm{H}\right.$, tosyl $\left.\mathrm{CH}_{3}\right), 2.10(\mathrm{dd}, 1 \mathrm{H}$, $\left.J=13.2,7.8 \mathrm{~Hz}, \mathrm{C}\left(\mathrm{CH}_{3}\right)_{2} \mathrm{CH}_{2}\right), 2.03\left(\mathrm{dd}, 1 \mathrm{H}, J=13.2,7.1 \mathrm{~Hz}, \mathrm{C}\left(\mathrm{CH}_{3}\right)_{2} \mathrm{CH}_{2}\right), 1.16(\mathrm{~s}, 3 \mathrm{H}$, $\left.\mathrm{COC}\left(\mathrm{CH}_{3}\right)_{2}\right), 1.06\left(\mathrm{~s}, 3 \mathrm{H}, \mathrm{COC}\left(\mathrm{CH}_{3}\right)_{2}\right), 1.04-0.93$ (m, $\left.21 \mathrm{H}, \mathrm{TIPS}\right) ;{ }^{13} \mathrm{C}$ NMR $(101 \mathrm{MHz}$, $\left.\mathrm{CDCl}_{3}\right) \delta 179.1,144.9,135.7,129.5,128.4,102.6,84.7,54.9,41.1,38.6,26.9,25.6,24.6$, 21.7, 18.6, 11.2; IR 2960 (m), 2942 (m), $2891(\mathrm{w}), 2866$ (m), 2360 (w), $2342(\mathrm{w}), 2176(\mathrm{w})$, 1739 (m), 1657 (w), 1598 (w), 1496 (w), 1463 (m), 1401 (w), 1385 (w), 1361 (s), 1307 (w), 1293 (w), 1235 (m), 1212 (w), 1188 (m), 1172 (s), 1114 (s), 1090 (s), 1069 (w), 1051 (w), $1025(\mathrm{~m}), 1000(\mathrm{w}), 953(\mathrm{w}), 904(\mathrm{~m}), 884(\mathrm{~m}), 838(\mathrm{w}), 814(\mathrm{~m}), 758(\mathrm{w}), 736(\mathrm{~m}), 719(\mathrm{~m})$, 707 (w), 675 (s), $664(\mathrm{~s}), 645(\mathrm{~m})$. Melting Point: 144.0 - $145.9^{\circ} \mathrm{C}$; HRMS (ESI) calcd for $\mathrm{C}_{25} \mathrm{H}_{40} \mathrm{NO}_{3} \mathrm{SSi}^{+}\left(\mathrm{M}+\mathrm{H}^{+}\right)$462.2498; found: 462.2510 .

\section{2-Tosyl-3-(3-(triisopropylsilyl)prop-2-ynyl)-2-azaspiro[4.5]decan-1-one (3e)}

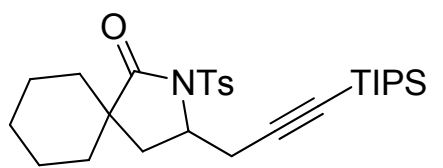

Column chromatography $\left(\mathrm{SiO}_{2}\right.$, PET/EtOAc 95/5) afforded product 3e (176 $\mathrm{mg}, 0.351 \mathrm{mmol}, 88 \%$ yield) as a yellow amorphous solid.

$\mathrm{R}_{\mathrm{f}} 0.80(\mathrm{PET} / \mathrm{EtOAc} 4 / 1) ;{ }^{1} \mathrm{H}$ NMR $\left(400 \mathrm{MHz}, \mathrm{CDCl}_{3}\right) \delta 7.93(\mathrm{~d}, 2 \mathrm{H}, J=8.4 \mathrm{~Hz}$, tosyl CH), $7.28(\mathrm{~d}, 2 \mathrm{H}, J=8.2 \mathrm{~Hz}$, tosyl $\mathrm{CH}), 4.32(\mathrm{~m}, 1 \mathrm{H}, \mathrm{NCH}), 3.00(\mathrm{dd}, 1 \mathrm{H}, J=17.0,3.5 \mathrm{~Hz}$, $\left.\mathrm{CH}_{2} \mathrm{C} \equiv \mathrm{C}\right), 2.88\left(\mathrm{dd}, 1 \mathrm{H}, J=16.9,7.5 \mathrm{~Hz}, \mathrm{CH}_{2} \mathrm{C} \equiv \mathrm{C}\right), 2.41\left(\mathrm{~s}, 3 \mathrm{H}\right.$, tosyl $\left.\mathrm{CH}_{3}\right), 2.24(\mathrm{dd}, 1 \mathrm{H}$, $\left.J=13.4,8.3 \mathrm{~Hz}, \mathrm{COCCH}_{2}\right), 2.01\left(\mathrm{dd}, 1 \mathrm{H}, J=13.4,6.3 \mathrm{~Hz}, \mathrm{COCCH}_{2}\right), 1.63(\mathrm{~m}, 4 \mathrm{H}$, cyclohexane), 1.44 (m, $2 \mathrm{H}$, cyclohexane), 1.26 (m, $4 \mathrm{H}$, cyclohexane), 1.09-0.89 (m, $21 \mathrm{H}$, TIPS); ${ }^{13} \mathrm{C}$ NMR $\left(101 \mathrm{MHz}, \mathrm{CDCl}_{3}\right) \delta 178.6,144.7,135.7,129.4,128.3,102.8,84.6,55.1$, 45.3, 34.6, 33.3, 33.2, 33.2, 27.2, 25.1, 21.7, 21.6, 18.5, 11.1; IR 2938 (m), 2892 (m), 2863 (m), $2364(\mathrm{w}), 2340(\mathrm{w}), 2175(\mathrm{w}), 1735(\mathrm{~m}), 1655(\mathrm{w}), 1598(\mathrm{w}), 1495(\mathrm{w}), 1462(\mathrm{~m}), 1451$ (m), $1401(\mathrm{w}), 1362(\mathrm{~m}), 1338(\mathrm{w}), 1308$ (w), $1283(\mathrm{w}), 1267$ (w), 1240 (w), 1206 (m), 1188 (m), $1171(\mathrm{~s}), 1112(\mathrm{~m}), 1091(\mathrm{~m}), 1075(\mathrm{w}), 1053(\mathrm{~m}), 1038(\mathrm{w}), 1018(\mathrm{w}), 996(\mathrm{w}), 940$ (w), $914(\mathrm{w}), 884(\mathrm{~m}), 851(\mathrm{w}), 839(\mathrm{w}), 814(\mathrm{~m}), 801(\mathrm{w}), 788(\mathrm{w}), 735(\mathrm{~s}), 716(\mathrm{w}), 706$ $(\mathrm{w}), 678(\mathrm{~s}), 665(\mathrm{~s}), 634(\mathrm{w}), 620(\mathrm{w})$; HRMS (ESI) calcd for $\mathrm{C}_{28} \mathrm{H}_{44} \mathrm{NO}_{3} \mathrm{SSi}^{+}\left(\mathrm{M}+\mathrm{H}^{+}\right)$ 502.2811; found 502.2805.

\section{2-Tosyl-3-(3-(triisopropylsilyl)prop-2-ynyl)-2-azaspiro[4.4]nonan-1-one (3f)}

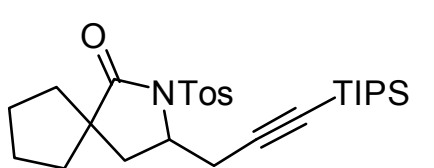

Column chromatography $\left(\mathrm{SiO}_{2}, \mathrm{PET} / \mathrm{EtOAc} 95 / 5\right)$ afforded product $3 f$ ( $150 \mathrm{mg}, 0.308 \mathrm{mmol}, 77 \%$ yield) as a colorless solid.

$\mathrm{R}_{\mathrm{f}} 0.70\left(\mathrm{PET} /\right.$ EtOAc 5/1); ${ }^{1} \mathrm{H}$ NMR $\left(400 \mathrm{MHz}, \mathrm{CDCl}_{3}\right) \delta 7.94(\mathrm{~m}$, $2 \mathrm{H}$, tosyl $\mathrm{CH}), 7.30(\mathrm{~d}, 2 \mathrm{H}, J=8.0 \mathrm{~Hz}$, tosyl $\mathrm{CH}), 4.36(\mathrm{~m}, 1 \mathrm{H}, \mathrm{NCH}), 3.02(\mathrm{dt}, 1 \mathrm{H}, J=$ 17.0, 3.1 Hz, $\left.\mathrm{CH}_{2} \mathrm{C} \equiv \mathrm{C}\right), 2.84\left(\mathrm{dd}, 1 \mathrm{H}, J=16.8,8.1 \mathrm{~Hz}, \mathrm{CH}_{2} \mathrm{C} \equiv \mathrm{C}\right), 2.42\left(\mathrm{~s}, 3 \mathrm{H}\right.$, tosyl $\left.\mathrm{CH}_{3}\right)$, $2.16\left(\mathrm{~d}, 2 \mathrm{H}, J=6.7 \mathrm{~Hz}, \mathrm{COCCH}_{2}\right), 1.96(\mathrm{~m}, 1 \mathrm{H}$, cyclopentyl), 1.86-1.40 (m, $7 \mathrm{H}$, cyclopentyl), 1.14-0.88 (m, $21 \mathrm{H}$, TIPS); ${ }^{13} \mathrm{C} \mathrm{NMR}\left(101 \mathrm{MHz}, \mathrm{CDCl}_{3}\right) \delta 179.3,144.9,135.8$, $129.5,128.3,102.9,84.6,55.7,51.0,38.4,38.4,37.3,26.7,25.7,25.4,21.7,18.6,11.2$; IR 2957 (m), 2943 (m), 2900 (w), 2888 (w), $2865(\mathrm{~m}), 2360(\mathrm{w}), 2342(\mathrm{w}), 2259(\mathrm{w}), 2175(\mathrm{w})$, 1737 (m), 1655 (w), 1598 (w), 1495 (w), 1463 (m), 1401 (w), 1361 (m), 1308 (w), 1292 (w), 
$1220(\mathrm{w}), 1200(\mathrm{w}), 1188(\mathrm{~m}), 1171(\mathrm{~s}), 1106(\mathrm{~m}), 1091(\mathrm{~m}), 1074(\mathrm{w}), 1063(\mathrm{w}), 1031(\mathrm{w})$, $1012(\mathrm{w}), 998(\mathrm{w}), 957(\mathrm{w}), 911(\mathrm{~m}), 884(\mathrm{~m}), 814(\mathrm{~m}), 733(\mathrm{~s}), 706(\mathrm{~m}), 665(\mathrm{~s}), 639(\mathrm{w})$, $624(\mathrm{w}), 619$ (w), 607 (w). Melting Point: 118.7 - $120.8{ }^{\circ} \mathrm{C}$; HRMS (ESI) calcd for $\mathrm{C}_{27} \mathrm{H}_{42} \mathrm{NO}_{3} \mathrm{SSi}^{+}[\mathrm{M}+\mathrm{H}]^{+}$488.2649; found 488.2638.

\section{4-Phenyl-1-tosyl-5-(3-(triisopropylsilyl)prop-2-ynyl)pyrrolidin-2-one (3g)}

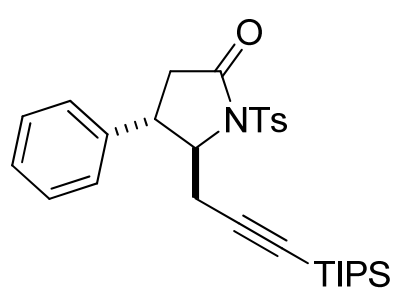

Column chromatography $\left(\mathrm{SiO}_{2}, \mathrm{PET} /\right.$ EtOAc 93/7) afforded product $3 \mathrm{~g}$ (145 mg, $0.284 \mathrm{mmol}, 71 \%$ yield) as a viscous, pale yellow oil (unseparable diastereoisomers; dr 90:10).

$\mathrm{R}_{\mathrm{f}} 0.79$ (PET/EtOAc 4/1); ${ }^{1} \mathrm{H}$ NMR (400 MHz, $\mathrm{CDCl}_{3}$, signals for the minor diastereoisomer are reported in italics) $\delta 8.02(\mathrm{~m}, 2 \mathrm{H}$, tosyl $\mathrm{CH}), 7.88(\mathrm{~m}, 2 \mathrm{H}$, tosyl $\mathrm{CH}), 7.36(\mathrm{~m}, 2 \mathrm{H}$, tosyl $\mathrm{CH}), 7.29$

(m, $2 \mathrm{H}$, tosyl $\mathrm{CH}), 7.22(\mathrm{~m}, 3 \mathrm{H}, \mathrm{Ph}$, both diastereoisomers), 7.01 (m, $2 \mathrm{H}, \mathrm{Ph}$, both), 4.68 $(\mathrm{ddd}, 1 \mathrm{H}, J=8.1,5.0,1.9 \mathrm{~Hz}, C H \mathrm{~N}), 4.33(\mathrm{~m}, 1 \mathrm{H}, C H \mathrm{~N}), 3.94(\mathrm{dt}, 1 \mathrm{H}, J=13.6,8.1 \mathrm{~Hz}$, CHPh), 3.68-3.50 (m, $2 \mathrm{H}, \mathrm{CHPh}$ and $\left.\mathrm{COCH}_{2}\right), 3.18\left(\mathrm{dd}, 1 \mathrm{H}, J=17.9,9.2 \mathrm{~Hz}, \mathrm{COCH}_{2}\right)$, 3.07-2.87 (m, $1 \mathrm{H}, \mathrm{CH}_{2} \mathrm{C} \equiv \mathrm{C}$, both), $2.60\left(\mathrm{dd}, 1 \mathrm{H}, J=16.7,8.2 \mathrm{~Hz}, \mathrm{COCH}_{2}\right), 2.53$ (dd, $1 \mathrm{H}, J$ $\left.=17.9,2.6 \mathrm{~Hz}, \mathrm{COCH}_{2}\right), 2.47\left(\mathrm{~s}, 3 \mathrm{H}\right.$, tosyl $\left.\mathrm{CH}_{3}\right), 2.44$ (s, tosyl $\left.\mathrm{CH}_{3}\right) .1 .16-0.79$ (m, TIPS, both); ${ }^{13} \mathrm{C}$ NMR $\left(101 \mathrm{MHz}, \mathrm{CDCl}_{3}\right)^{[27]} \delta 172.7,172.1,145.0,144.7,142.7,135.4,135.2$, $129.4,129.0,128.6,128.6,128.3,128.0,127.7,127.3,126.0,103.1,102.5,85.6,84.9,66.3$, 61.3, 43.0, 41.3, 38.0, 35.7, 26.5, 21.6, 18.5, 18.4, 18.3, 11.1; IR 3067 (w), 3032 (w), 3014 (w), 2943 (w), 2891 (w), 2865 (w), $2361(\mathrm{w}), 2344(\mathrm{w}), 2257$ (w), $2174(\mathrm{w}), 1738(\mathrm{~m}), 1598$ (w), 1495 (w), 1463 (w), 1429 (w), 1401 (w), 1362 (m), 1333 (w), 1308 (w), 1293 (w), 1241 (w), $1216(\mathrm{w}), 1187$ (w), 1170 (s), 1143 (w), $1113(\mathrm{~m}), 1090(\mathrm{w}), 1042(\mathrm{w}), 1034$ (w), 1020 (w), $997(\mathrm{w}), 989(\mathrm{w}), 961(\mathrm{w}), 947(\mathrm{w}), 909(\mathrm{~s}), 884(\mathrm{~m}), 814(\mathrm{w}), 764(\mathrm{w}), 731(\mathrm{~s}), 702(\mathrm{~m})$, 675 (s), $668(\mathrm{~s}), 650(\mathrm{~m}), 631(\mathrm{w}), 612(\mathrm{~m})$; HRMS (ESI) calcd for $\mathrm{C}_{29} \mathrm{H}_{40} \mathrm{NO}_{3} \mathrm{SSi}^{+}\left(\mathrm{M}+\mathrm{H}^{+}\right)$ 510.2498; found 510.2518.

\section{2-Tosyl-3-(3-(triisopropylsilyl)prop-2-ynyl)octahydro-1H-isoindol-1-one (3h)}

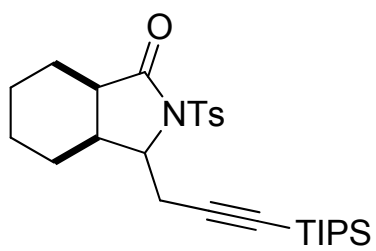

Column chromatography $\left(\mathrm{SiO}_{2}, \mathrm{PET} /\right.$ EtOAc 98/2) afforded product 3h (130 mg, $0.267 \mathrm{mmol}, 67 \%$ yield) as a pale yellow oil (unseparable diastereoisomers; dr 70:30).

$\mathrm{R}_{\mathrm{f}} 0.86\left(\mathrm{PET} /\right.$ EtOAc 4/1); ${ }^{1} \mathrm{H}$ NMR $\left(400 \mathrm{MHz}, \mathrm{CDCl}_{3}\right) \delta 7.92(\mathrm{~d}, 2$ $\mathrm{H}, J=8.0 \mathrm{~Hz}$, tosyl $\mathrm{CH}$, major diastereoisomer), $7.85(\mathrm{~d}, 2 \mathrm{H}, J=7.9$ $\mathrm{Hz}$, tosyl $\mathrm{CH}$, minor diastereoisomer), $7.30(\mathrm{~d}, 2 \mathrm{H}, J=8.0 \mathrm{~Hz}$, tosyl $\mathrm{CH}$, both diasteroisomers), 4.14 (m, $1 \mathrm{H}, \mathrm{NCH}$, minor), 3.88 (dd, $1 \mathrm{H}, J=8.9,3.3 \mathrm{~Hz}, \mathrm{NCH}$, major), 3.61 (dd, $1 \mathrm{H}, J=16.5,4.5 \mathrm{~Hz}, \mathrm{CH}_{2} \mathrm{C} \equiv \mathrm{C}$, minor), 2.98 (m, $1 \mathrm{H}, C H C H C H N$, major), 2.92 (dd, $1 \mathrm{H}, J=16.9,3.2 \mathrm{~Hz}, \mathrm{CH}_{2} \mathrm{C} \equiv \mathrm{C}$, major), $2.72\left(\mathrm{dd}, 1 \mathrm{H}, J=16.8,9.0 \mathrm{~Hz}, \mathrm{CH}_{2} \mathrm{C} \equiv \mathrm{C}\right.$, major), 2.56-2.36 (m, $1 \mathrm{H}, \mathrm{CHCHCHN}$, major, $3 \mathrm{H}, \mathrm{CHCHCHN}$ and $\mathrm{CH}_{2} \mathrm{C} \equiv \mathrm{C}$, minor), 2.41 (s, $3 \mathrm{H}$, tosyl $\mathrm{CH}_{3}$, both), 2.15-1.96 (m, $\left(\mathrm{CH}_{2}\right)_{4}$, both), 1.85-1.27 (m, $\left(\mathrm{CH}_{2}\right)_{4}$, both), 1.12-0.92 (m, TIPS and $\left(\mathrm{CH}_{2}\right)_{4}$, both) ${ }^{[28]}{ }^{13} \mathrm{C} \mathrm{NMR}\left(101 \mathrm{MHz}, \mathrm{CDCl}_{3}, \delta 175.8,174.1,144.9,144.7\right.$, $136.1,135.5,129.6,129.4,128.2$, 127.7, 103.6, 102.9, 84.0, 83.5, 63.1, 61.1, 46.2, 43.4, 40.3,

[27] Some signals corresponding to the minor diastereoisomer were not detected.

[28] Partial assignment of the spectrum was possible on the basis of 2D-NMR experiments. 
37.1, 35.6, 29.1, 24.4, 23.6, 23.4, 22.4, 22.3, 22.2, 22.2, 22.1, 21.0, 18.5, 18.4, 11.1, 11.1; IR 2941 (m), 2900 (w), 2892 (w), 2864 (m), 2364 (w), 2343 (w), $2334(\mathrm{w}), 2175(\mathrm{w}), 1743(\mathrm{~m})$, 1598 (w), 1495 (w), 1463 (m), 1451 (w), 1400 (w), 1365 (m), 1307 (w), 1299 (w), $1281(\mathrm{w})$, 1250 (w), 1237 (w), $1214(\mathrm{w}), 1187$ (m), 1170 (s), 1136 (m), 1108 (m), 1092 (m), 1062 (w), $1053(\mathrm{w}), 1031(\mathrm{w}), 1018(\mathrm{w}), 994(\mathrm{w}), 971(\mathrm{w}), 950(\mathrm{w}), 914(\mathrm{~m}), 883(\mathrm{~m}), 863(\mathrm{w}), 827$ (w), $814(\mathrm{~m}), 800(\mathrm{w}), 778(\mathrm{w}), 760(\mathrm{w}), 735$ (s), 705 (m), 667 (s), 636 (m), 619 (m); HRMS (ESI) calcd for $\mathrm{C}_{27} \mathrm{H}_{42} \mathrm{NO}_{3} \mathrm{SSi}^{+}\left(\mathrm{M}+\mathrm{H}^{+}\right)$488.2655; found 488.2645 .

\section{1-Tosyl-6-(3-(triisopropylsilyl)prop-2-ynyl)piperidin-2-one (3i)}

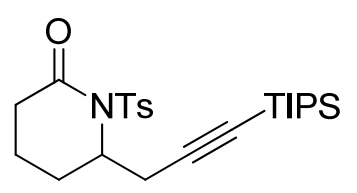

Column chromatography $\left(\mathrm{SiO}_{2}, \mathrm{PET} /\right.$ EtOAc $95 / 5$ to $\left.90 / 10\right)$ afforded product $3 \mathbf{i}$ (102 $\mathrm{mg}, 0.228 \mathrm{mmol}, 57 \%$ yield) as a pale yellow solid.

$\mathrm{R}_{\mathrm{f}} 0.51(\mathrm{PET} / \mathrm{EtOAc} 4 / 1) ;{ }^{1} \mathrm{H}$ NMR $\left(400 \mathrm{MHz}, \mathrm{CDCl}_{3}\right) \delta 7.93(\mathrm{~m}, 2 \mathrm{H}$, tosyl $\mathrm{CH}), 7.30(\mathrm{~m}, 2 \mathrm{H}$, tosyl $\mathrm{CH}), 4.74(\mathrm{~m}, 1 \mathrm{H}, \mathrm{CHN}), 2.95(\mathrm{dd}, 1 \mathrm{H}$, $\left.J=16.6,3.5 \mathrm{~Hz}, \mathrm{CH}_{2} \mathrm{C} \equiv \mathrm{C}\right), 2.75\left(\mathrm{dd}, 1 \mathrm{H}, J=17.1,9.5 \mathrm{~Hz}, \mathrm{CH}_{2} \mathrm{C} \equiv \mathrm{C}\right), 2.55-2.34(\mathrm{~m}, 3 \mathrm{H}$, $\left.\mathrm{COCH}_{2} \mathrm{CH}_{2}\right), 2.43\left(\mathrm{~s}, 3 \mathrm{H}\right.$, tosyl $\left.\mathrm{CH}_{3}\right), 2.06\left(\mathrm{~m}, 1 \mathrm{H}, \mathrm{COCH}_{2} \mathrm{CH}_{2} \mathrm{CH}_{2}\right), 1.88(\mathrm{~m}, 1 \mathrm{H}$, $\mathrm{COCH}_{2} \mathrm{CH}_{2} \mathrm{CH}_{2}$ ), 1.77 (m, $1 \mathrm{H}, \mathrm{COCH}_{2} \mathrm{CH}_{2} \mathrm{CH}_{2}$ ), 1.18-0.92 (m, $\left.21 \mathrm{H}, \mathrm{TIPS}\right) ;{ }^{13} \mathrm{C}$ NMR (101 $\left.\mathrm{MHz}, \mathrm{CDCl}_{3}\right) \delta 170.0,144.6,136.3,129.1,128.9,103.1,84.5,54.9,33.4,26.5,26.2,21.5$, 18.5, 16.0, 11.1; IR 2943 (m), 2927 (m), 2891 (w), 2865 (m), 2174 (w), 1698 (m), 1597 (w), $1597(\mathrm{w}), 1495$ (w), 1463 (m), 1429 (w), 1429 (w), 1382 (w), 1352 (m), $1306(\mathrm{w}), 1306$ (w), 1292 (w), 1259 (m), 1234 (w), 1217 (w), $1217(\mathrm{w}), 1188(\mathrm{w}), 1164(\mathrm{~s}), 1121(\mathrm{~m}), 1088(\mathrm{~m})$, $1034(\mathrm{w}), 1019(\mathrm{w}), 1007(\mathrm{w}), 992(\mathrm{w}), 953(\mathrm{w}), 911(\mathrm{w}), 884(\mathrm{~m}), 860(\mathrm{w}), 845(\mathrm{w}), 813$ (m), $768(\mathrm{w}), 732(\mathrm{~m}), 705(\mathrm{w}), 673(\mathrm{~s}), 663(\mathrm{~s}), 626(\mathrm{~m}), 618(\mathrm{~m})$; Melting Point: 72.2 $73.9^{\circ} \mathrm{C}$; HRMS (ESI) calcd for $\mathrm{C}_{24} \mathrm{H}_{38} \mathrm{NO}_{3} \mathrm{SSi}^{+}\left(\mathrm{M}+\mathrm{H}^{+}\right)$448.2342; found 448.2360.

\section{2-Tosyl-3-(3-(triisopropylsilyl)prop-2-ynyl)-3,4-dihydroisoquinolin-1(2H)-one (3j)}

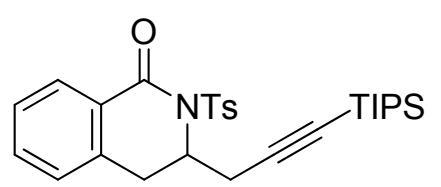

Column chromatography $\left(\mathrm{SiO}_{2}, \mathrm{PET} / \mathrm{EtOAc} 95 / 5\right.$ to $\left.90 / 10\right)$ afforded product $\mathbf{3 j}$ (167 $\mathrm{mg}, 0.337 \mathrm{mmol}, 84 \%$ yield) as a pale yellow amorphous solid.

$\mathrm{R}_{\mathrm{f}} 0.57\left(\mathrm{PET} /\right.$ EtOAc 4/1); ${ }^{1} \mathrm{H}$ NMR $\left(400 \mathrm{MHz}, \mathrm{CDCl}_{3}\right) \delta 8.01(\mathrm{~m}$, $2 \mathrm{H}$, tosyl CH), 7.98 (dd, $1 \mathrm{H}, J=8.0,1.0 \mathrm{~Hz}, \mathrm{Ar} H), 7.50$ (td, $1 \mathrm{H}, J=7.5,1.1 \mathrm{~Hz}, \operatorname{Ar} H)$, 7.38-7.28 (m, $3 \mathrm{H}$, tosyl $\mathrm{CH}$ and $\operatorname{Ar} H), 7.20(\mathrm{~d}, 1 \mathrm{H}, J=7.5 \mathrm{~Hz}, \operatorname{Ar} H), 5.09(\mathrm{~m}, 1 \mathrm{H}, C H \mathrm{~N})$, 3.49 (dd, $\left.1 \mathrm{H}, J=16.1,1.5 \mathrm{~Hz}, \mathrm{CH}_{2} \mathrm{C} \equiv \mathrm{C}\right), 3.34$ (dd, $\left.1 \mathrm{H}, J=16.1,5.5 \mathrm{~Hz}, \mathrm{CH}_{2} \mathrm{C} \equiv \mathrm{C}\right), 2.54-$ 2.37 (m, $\left.2 \mathrm{H}, \mathrm{CH}_{2} \mathrm{CHN}\right), 2.41$ (s, $3 \mathrm{H}$, tosyl $\mathrm{CH}_{3}$ ), 1.19-0.94 (m, $\left.21 \mathrm{H}, \mathrm{TIPS}\right) ;{ }^{13} \mathrm{C}$ NMR (101 $\left.\mathrm{MHz}, \mathrm{CDCl}_{3}\right) \delta 162.3,144.8,136.4,136.2,133.8,129.3,128.9,128.8,128.3,127.7,127.5$, 103.1, 84.5, 54.1, 31.2, 24.9, 21.6, 18.6, 11.1; IR 2957 (w), 2943 (m), 2901 (w), 2865 (m), $2175(\mathrm{w}), 1692(\mathrm{~m}), 1603(\mathrm{w}), 1493(\mathrm{w}), 1461(\mathrm{w}), 1429(\mathrm{w}), 1381(\mathrm{w}), 1353(\mathrm{~m}), 1295(\mathrm{w})$, $1274(\mathrm{w}), 1243$ (m), 1188 (w), 1168 (s), 1113 (w), 1089 (w), 1060 (m), 1032 (w), 1019 (w), $1019(\mathrm{w}), 1000(\mathrm{w}), 884(\mathrm{w}), 834(\mathrm{w}), 814(\mathrm{w}), 794(\mathrm{w}), 761(\mathrm{w}), 740(\mathrm{~m}), 719(\mathrm{w}), 703(\mathrm{w})$, $682(\mathrm{~m}), 666(\mathrm{~s}), 656(\mathrm{~m}), 646(\mathrm{w}), 637(\mathrm{~m}), 625(\mathrm{w}), 614(\mathrm{w})$; HRMS (ESI) calcd for $\mathrm{C}_{28} \mathrm{H}_{38} \mathrm{NO}_{3} \mathrm{SSi}^{+}\left(\mathrm{M}+\mathrm{H}^{+}\right)$496.2342; found 496.2340.

2-Tosyl-3-(3-(triisopropylsilyl)prop-2-ynyl)-3,4-dihydropyrrolo[1,2-a]pyrazin-1(2H)-one $(3 k)$ 


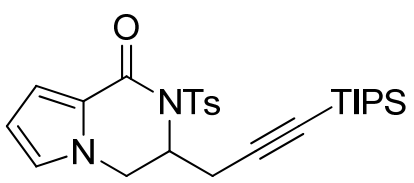

Column chromatography $\left(\mathrm{SiO}_{2}\right.$, PET/EtOAc $95 / 5$ to $\left.90 / 10\right)$ afforded product $3 \mathbf{k}(170 \mathrm{mg}, 0.351 \mathrm{mmol}, 88 \%$ yield) as a pale yellow solid.

$\mathrm{R}_{\mathrm{f}} 0.50$ (Hex/EtOAc 4/1); ${ }^{1} \mathrm{H}$ NMR $\left(400 \mathrm{MHz}, \mathrm{CDCl}_{3}\right) \delta 8.00(\mathrm{~m}$, $2 \mathrm{H}$, tosyl $\mathrm{CH}$ ), $7.33(\mathrm{~m}, 2 \mathrm{H}$, tosyl $\mathrm{CH}), 6.98(\mathrm{dd}, 1 \mathrm{H}, J=3.9,1.1 \mathrm{~Hz}$, pyrrole), 6.74 (m, 1 $\mathrm{H}$, pyrrole), $6.25(\mathrm{dd}, 1 \mathrm{H}, J=3.9,2.5 \mathrm{~Hz}$, pyrrole), $5.06(\mathrm{~m}, 1 \mathrm{H}, C H \mathrm{~N}), 4.67(\mathrm{dd}, 1 \mathrm{H}, J=$ 13.0, $1.2 \mathrm{~Hz}, \mathrm{NCH}_{2}$ ), 4.28 (dd, $1 \mathrm{H}, J=13.0,3.8 \mathrm{~Hz}, \mathrm{NCH}_{2}$ ), 2.83 (ddd, $1 \mathrm{H}, J=16.6,4.5$, $\left.1.0 \mathrm{~Hz}, \mathrm{CH}_{2} \mathrm{C} \equiv \mathrm{C}\right), 2.56-2.32\left(\mathrm{~m}, 1 \mathrm{H}, \mathrm{CH}_{2} \mathrm{C} \equiv \mathrm{C}\right), 2.42\left(\mathrm{~s}, 3 \mathrm{H}\right.$, tosyl $\left.\mathrm{CH}_{3}\right), 1.16-0.96(\mathrm{~m}, 21 \mathrm{H}$, TIPS); ${ }^{13} \mathrm{C}$ NMR (101 MHz, $\left.\mathrm{CDCl}_{3}\right) \delta$ 155.5, 145.0, 136.4, 129.4, 128.9, 125.4, 122.2, 117.1, 111.3, 102.3, 85.5, 54.5, 45.9, 23.9, 21.7, 18.6, 11.2; IR 2943 (m), 2891 (w), 2865 (m), 2176 (w), $1738(\mathrm{w}), 1686(\mathrm{~s}), 1597(\mathrm{w}), 1536(\mathrm{~m}), 1487$ (m), $1463(\mathrm{w}), 1403(\mathrm{~m}), 1354(\mathrm{~s}), 1320$ (w), $1293(\mathrm{w}), 1259$ (w), 1233 (w), $1204(\mathrm{~m}), 1189$ (w), $1168(\mathrm{~s}), 1135$ (w), 1087 (m), 1075 (m), 1058 (s), 1034 (w), 1018 (w), $1007(\mathrm{~m}), 913$ (w), 899 (w), $884(\mathrm{w}), 813(\mathrm{w}), 758(\mathrm{w})$, $737(\mathrm{~s}), 706(\mathrm{w}), 679(\mathrm{~m}), 661(\mathrm{~s}), 639(\mathrm{w}), 625$ (w), 609 (w); Melting Point: 158.2 161.0 ${ }^{\circ} \mathrm{C}$; HRMS (ESI) calcd for $\mathrm{C}_{26} \mathrm{H}_{37} \mathrm{~N}_{2} \mathrm{O}_{3} \mathrm{SSi}^{+}\left(\mathrm{M}+\mathrm{H}^{+}\right)$485.2294; found 485.2299.

\section{2-Tosyl-3-(3-(triisopropylsilyl)prop-2-ynyl)-3,4-dihydropyrazino[1,2-a]indol-1(2H)-one}

(3I)

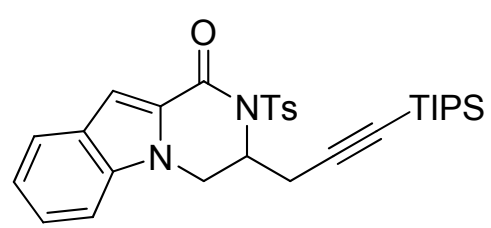

Column chromatography $\left(\mathrm{SiO}_{2}, \mathrm{PET} /\right.$ EtOAc $95 / 5$ to $\left.90 / 10\right)$ afforded product 31 (191 $\mathrm{mg}, 0.357 \mathrm{mmol}, 89 \%$ yield) as a pale yellow amorphous solid.

$\mathrm{R}_{\mathrm{f}} 0.67$ (PET/EtOAc 5/1); ${ }^{1} \mathrm{H}$ NMR $\left(400 \mathrm{MHz}, \mathrm{CDCl}_{3}\right) \delta 8.06$ (m, $2 \mathrm{H}$, tosyl $\mathrm{CH}), 7.68(\mathrm{~d}, 1 \mathrm{H}, J=8.1 \mathrm{~Hz}$, indole), 7.43-7.27 (m, $5 \mathrm{H}$, tosyl $\mathrm{CH}$ and indole), $7.17\left(\mathrm{~m}, 1 \mathrm{H}\right.$, indole), $5.23(\mathrm{~m}, 1 \mathrm{H}, C H \mathrm{~N}), 5.01\left(\mathrm{dd}, 1 \mathrm{H}, J=12.8,1.2 \mathrm{~Hz}, \mathrm{NCH}_{2}\right), 4.26$ (dd, $\left.1 \mathrm{H}, J=12.8,3.8 \mathrm{~Hz}, \mathrm{NCH}_{2}\right), 2.86\left(\mathrm{dd}, 1 \mathrm{H}, J=16.8,3.8 \mathrm{~Hz}, \mathrm{CH}_{2} \mathrm{C} \equiv \mathrm{C}\right), 2.51(\mathrm{dd}, 1 \mathrm{H}, J=$ 16.7, $\left.11.4 \mathrm{~Hz}, \mathrm{CH}_{2} \mathrm{C} \equiv \mathrm{C}\right), 2.44$ (m, $3 \mathrm{H}$, tosyl $\mathrm{CH}_{3}$ ), 1.14-1.05 (m, $\left.21 \mathrm{H}, \mathrm{TIPS}\right) ;{ }^{13} \mathrm{C}$ NMR $\left(101 \mathrm{MHz} \mathrm{CDCl}_{3}\right) \delta 156.6,145.1,137.1,136.0,129.4,128.9,127.2,126.4,126.0,122.9$, 121.3, 109.8, 109.4, 102.1, 85.4, 54.8, 42.3, 24.4, 21.6, 18.6, 11.1; IR $3064(\mathrm{w}), 3060(\mathrm{w})$, $3056(\mathrm{w}), 3041(\mathrm{w}), 2943(\mathrm{w}), 2891(\mathrm{w}), 2865(\mathrm{w}), 2362(\mathrm{w}), 2343(\mathrm{w}), 2331(\mathrm{w}), 2256(\mathrm{w})$, 2175 (w), 1690 (m), 1617 (w), 1597 (w), 1569 (w), 1538 (m), 1493 (w), $1487(\mathrm{w}), 1469$ (w), 1449 (w), 1416 (w), 1379 (m), 1350 (m), 1319 (w), 1307 (w), 1294 (w), 1255 (m), 1233 (w), $1210(\mathrm{~m}), 1187(\mathrm{~m}), 1168(\mathrm{~s}), 1140(\mathrm{~m}), 1119(\mathrm{w}), 1088(\mathrm{~m}), 1056(\mathrm{~m}), 1034(\mathrm{w}), 1019(\mathrm{w})$, 998 (w), 969 (w), 909 (m), 884 (m), 864 (w), 842 (w), 815 (w), 731 (s), 717 (s), 666 (s), 648 (m), $628(\mathrm{w}), 612(\mathrm{w})$; HRMS (ESI) calcd for $\mathrm{C}_{30} \mathrm{H}_{39} \mathrm{~N}_{2} \mathrm{O}_{3} \mathrm{SSi}^{+}\left(\mathrm{M}+\mathrm{H}^{+}\right)$535.2451; found 535.2461 .

\section{3-Tosyl-4-(3-(triisopropylsilyl)prop-2-ynyl)oxazolidin-2-one (7a)}

Column chromatography ( $\mathrm{SiO}_{2}$, PET/EtOAc 94/6 to 93/7) afforded product 7a (144 mg, $0.331 \mathrm{mmol}, 83 \%$ yield) as a colorless solid.

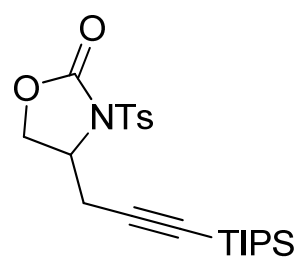

$\mathrm{R}_{\mathrm{f}} 0.56(\mathrm{PET} / \mathrm{EtOAc} 4 / 1) ;{ }^{1} \mathrm{H}$ NMR $\left(400 \mathrm{MHz}, \mathrm{CDCl}_{3}\right) \delta 7.97(\mathrm{~m}, 2 \mathrm{H}$, tosyl $\mathrm{CH}), 7.34(\mathrm{~m}, 2 \mathrm{H}$, tosyl $\mathrm{CH}), 4.61(\mathrm{~m}, 1 \mathrm{H}, C H \mathrm{~N}), 4.46(\mathrm{~m}, 1 \mathrm{H}$, $\left.\mathrm{OCH}_{2}\right), 4.34\left(\mathrm{~m}, 1 \mathrm{H}, \mathrm{OCH}_{2}\right), 2.93\left(\mathrm{dd}, J=17.0,6.4 \mathrm{~Hz}, \mathrm{CH}_{2} \mathrm{C} \equiv \mathrm{C}\right), 2.82$ (m, $\left.1 \mathrm{H}, \mathrm{CH}_{2} \mathrm{C} \equiv \mathrm{C}\right), 2.44\left(\mathrm{~s}, 3 \mathrm{H}\right.$, tosyl $\left.\mathrm{CH}_{3}\right), 1.05-0.88$ (m, $21 \mathrm{H}$, TIPS); 
${ }^{13} \mathrm{C}$ NMR $\left(101 \mathrm{MHz}, \mathrm{CDCl}_{3}\right) \delta 151.8,145.6,134.8,129.8,128.5,100.0,85.6,66.8,55.1$, 25.4, 21.7, 18.4, 11.0; IR 2943 (m), 2891 (w), 2865 (m), 2362 (w), 2177 (w), 1783 (s), 1598 (w), 1495 (w), 1463 (w), $1430(\mathrm{w}), 1394(\mathrm{~m}), 1368(\mathrm{~m}), 1335(\mathrm{w}), 1293(\mathrm{w}), 1218(\mathrm{w}), 1187$ (s), 1173 (s), 1135 (s), 1093 (m), 1054 (w), $1016(\mathrm{w}), 998(\mathrm{w}), 976(\mathrm{w}), 913$ (w), $884(\mathrm{~m})$, $815(\mathrm{w}), 761(\mathrm{w}), 751(\mathrm{w}), 735$ (m), $718(\mathrm{w}), 704(\mathrm{w}), 679$ (s), 669 (s), 639 (w); Melting Point: $88.7-90.8^{\circ} \mathrm{C}$; HRMS (ESI) calcd for $\mathrm{C}_{22} \mathrm{H}_{34} \mathrm{NO}_{4} \mathrm{SSi}^{+}\left(\mathrm{M}+\mathrm{H}^{+}\right)$436.1978; found 436.1974 .

\section{5-Methyl-3-tosyl-4-(3-(triisopropylsilyl)prop-2-ynyl)oxazolidin-2-one (7b)}

Column chromatography $\left(\mathrm{SiO}_{2}, \mathrm{PET} /\right.$ EtOAc $95 / 5$ to $\left.90 / 10\right)$ afforded product $7 \mathbf{b}(119 \mathrm{mg}$, $0.265 \mathrm{mmol}, 66 \%$ yield) as a pair of separable diastereoisomers (dr 61:39; relative stereochemistry assigned on the basis of NOESY).

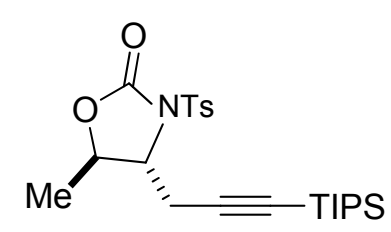

Major diastereoisomer: colorless solid (72 mg, $0.16 \mathrm{mmol}, 40 \%$ yield). $\mathrm{R}_{\mathrm{f}} 0.69$ (PET/EtOAc 4/1); ${ }^{1} \mathrm{H}$ NMR (400 MHz, $\left.\mathrm{CDCl}_{3}\right) \delta$ $7.95(\mathrm{~d}, 2 \mathrm{H}, J=8.3 \mathrm{~Hz}$, tosyl $\mathrm{CH}), 7.34(\mathrm{~d}, 2 \mathrm{H}, J=8.2 \mathrm{~Hz}$, tosyl $\mathrm{CH}), 4.60\left(\mathrm{qd}, 1 \mathrm{H}, J=6.3,3.4 \mathrm{~Hz}, \mathrm{OCHCH}_{3}\right), 4.10(\mathrm{~m}, 1 \mathrm{H}, \mathrm{CHN})$, $2.89\left(\mathrm{dd}, 1 \mathrm{H}, J=17.1,3.5 \mathrm{~Hz}, \mathrm{CH}_{2} \mathrm{C} \equiv \mathrm{C}\right), 2.82(\mathrm{dd}, 1 \mathrm{H}, J=17.1$, $\left.7.0 \mathrm{~Hz}, \mathrm{CH}_{2} \mathrm{C} \equiv \mathrm{C}\right), 2.43\left(\mathrm{~s}, 3 \mathrm{H}\right.$, tosyl $\left.\mathrm{CH}_{3}\right), 1.39$ (d, $\left.3 \mathrm{H}, J=6.4 \mathrm{~Hz}, \mathrm{OCHCH}_{3}\right), 1.13-0.88$ (m, $21 \mathrm{H}, \mathrm{TIPS}) ;{ }^{13} \mathrm{C}$ NMR $\left(101 \mathrm{MHz}, \mathrm{CDCl}_{3}\right) \delta 151.2,145.5,134.8,129.7,128.4,100.4$, 85.5, 75.7, 61.5, 25.3, 21.6, 21.0, 18.4, 11.0; IR 2943 (m), $2892(\mathrm{w}), 2865$ (m), $2361(\mathrm{w})$, 2341 (w), 2177 (w), 1785 (s), 1784 (s), 1597 (w), 1508 (w), 1495 (w), 1463 (w), 1369 (s), $1328(\mathrm{w}), 1310(\mathrm{w}), 1292(\mathrm{w}), 1279(\mathrm{w}), 1252$ (w), $1244(\mathrm{w}), 1220(\mathrm{w}), 1189(\mathrm{~s}), 1174(\mathrm{~s})$, 1138 (s), 1092 (m), $1054(\mathrm{~m}), 1019(\mathrm{w}), 997(\mathrm{w}), 986(\mathrm{w}), 918(\mathrm{w}), 884(\mathrm{~m}), 837(\mathrm{w}), 814$ (w), $801(\mathrm{w}), 794(\mathrm{w}), 786(\mathrm{w}), 754(\mathrm{~m}), 736(\mathrm{~m}), 706$ (w), $676(\mathrm{~s}), 649(\mathrm{~m}), 641(\mathrm{~m}), 612$ (m); Melting Point: $62.5-64.2^{\circ} \mathrm{C}$; HRMS (ESI) calcd for $\mathrm{C}_{23} \mathrm{H}_{36} \mathrm{NO}_{4} \mathrm{SSi}^{+}\left(\mathrm{M}+\mathrm{H}^{+}\right)$450.2134; found 450.2135 .

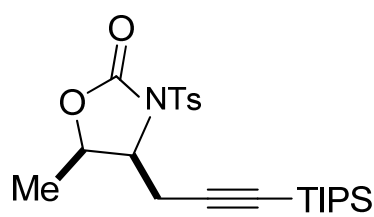

Minor diastereoisomer: colorless solid (47 $\mathrm{mg}, 0.10 \mathrm{mmol}, 26 \%$ yield). $\mathrm{R}_{\mathrm{f}} 0.57$ (PET/EtOAc 4/1); ${ }^{1} \mathrm{H}$ NMR (400 MHz, $\left.\mathrm{CDCl}_{3}\right) \delta 7.99$ (m, $2 \mathrm{H}$, tosyl $\mathrm{CH}$ ), $7.33(\mathrm{~d}, 2 \mathrm{H}, J=8.2 \mathrm{~Hz}$, tosyl $\mathrm{CH}$ ), 4.81 (quint, 1 $\left.\mathrm{H}, J=6.7 \mathrm{~Hz}, \mathrm{OCHCH}_{3}\right), 4.50(\mathrm{~m}, 1 \mathrm{H}, \mathrm{CHN}), 2.94(\mathrm{dd}, 1 \mathrm{H}, J=$ 17.6, $\left.6.0 \mathrm{~Hz}, \mathrm{CH}_{2} \mathrm{C} \equiv \mathrm{C}\right), 2.69\left(\mathrm{dd}, 1 \mathrm{H}, J=18.1,2.5 \mathrm{~Hz}, \mathrm{CH}_{2} \mathrm{C} \equiv \mathrm{C}\right)$, $2.43\left(\mathrm{~s}, 3 \mathrm{H}\right.$, tosyl $\left.\mathrm{CH}_{3}\right), 1.61\left(\mathrm{~d}, 3 \mathrm{H}, J=6.6 \mathrm{~Hz}, \mathrm{OCHCH}_{3}\right), 0.98-0.91(\mathrm{~m}, 21 \mathrm{H}, \mathrm{TIPS}) ;{ }^{13} \mathrm{C}$ $\operatorname{NMR}\left(101 \mathrm{MHz}, \mathrm{CDCl}_{3}\right) \delta 151.3,145.3,135.0,129.7,128.7,100.8,86.3,75.1,58.7,21.7$, 20.8, 18.4, 14.1, 11.1; IR 2942 (w), 2902 (w), 2865 (w), 2360 (w), 2343 (w), 2175 (w), 1790 (m), 1598 (w), 1507 (w), $1495(\mathrm{w}), 1464(\mathrm{w}), 1426(\mathrm{w}), 1392(\mathrm{w}), 1367$ (m), $1322(\mathrm{w}), 1285$ (w), $1214(\mathrm{w}), 1195(\mathrm{~m}), 1186(\mathrm{~m}), 1172$ (s), $1137(\mathrm{~m}), 1115(\mathrm{~s}), 1091(\mathrm{w}), 1072$ (w), 1042 (w), $1019(\mathrm{w}), 998(\mathrm{w}), 981(\mathrm{w}), 913(\mathrm{w}), 901(\mathrm{w}), 884(\mathrm{w}), 825(\mathrm{w}), 815(\mathrm{w}), 802(\mathrm{w}), 757$ (w), $736(\mathrm{w}), 729(\mathrm{w}), 707(\mathrm{~m}), 695(\mathrm{~m}), 681(\mathrm{~m}), 661(\mathrm{~s}), 645(\mathrm{w}), 623(\mathrm{~m}), 615(\mathrm{~m}), 610$ (m); Melting Point: $109.0-111.2^{\circ} \mathrm{C}$; HRMS (ESI) calcd for $\mathrm{C}_{23} \mathrm{H}_{36} \mathrm{NO}_{4} \mathrm{SSi}^{+}\left(\mathrm{M}+\mathrm{H}^{+}\right)$ 450.2134; found 450.2135 .

\section{5-Cyclohexyl-3-tosyl-4-(3-(triisopropylsilyl)prop-2-ynyl)oxazolidin-2-one (7c)}


Column chromatography $\left(\mathrm{SiO}_{2}, \mathrm{PET} /\right.$ EtOAc $97 / 3$ to $\left.90 / 10\right)$ afforded product 7c $(120 \mathrm{mg}$, $0.232 \mathrm{mmol}, 58 \%$ yield) as a pair of separable diastereoisomers (dr 66:34; relative stereochemistry assigned on the basis of NOESY).

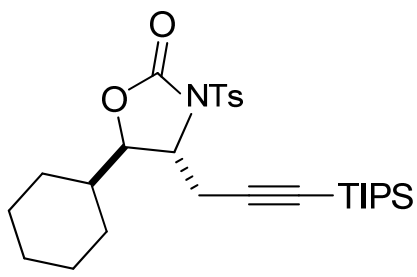

Major diastereoisomer: yellow solid (79 mg, $0.15 \mathrm{mmol}, 38 \%$ yield). $\mathrm{R}_{\mathrm{f}} 0.87$ (PET/EtOAc 4/1); ${ }^{1} \mathrm{H}$ NMR (400 MHz, $\left.\mathrm{CDCl}_{3}\right) \delta$ $7.94(\mathrm{~m}, 2 \mathrm{H}$, tosyl $\mathrm{CH}), 7.32(\mathrm{~m}, 2 \mathrm{H}$, tosyl $\mathrm{CH}), 4.29(\mathrm{~m}, 1 \mathrm{H}$, $\mathrm{OCH}), 4.20(\mathrm{~m}, 1 \mathrm{H}, C H \mathrm{~N}), 2.87(\mathrm{dd}, 1 \mathrm{H}, J=17.1,7.0 \mathrm{~Hz}$, $\left.\mathrm{CH}_{2} \mathrm{C} \equiv \mathrm{C}\right), 2.77\left(\mathrm{dd}, 1 \mathrm{H}, J=17.1,3.0 \mathrm{~Hz}, \mathrm{CH}_{2} \mathrm{C} \equiv \mathrm{C}\right), 2.42(\mathrm{~s}, 3 \mathrm{H}$, tosyl $\left.\mathrm{CH}_{3}\right), 1.85-1.47$ (m, $5 \mathrm{H}$, cyclohexane), 1.30-0.80 (m, $27 \mathrm{H}$, cyclohexane and TIPS); ${ }^{13} \mathrm{C}$ NMR $\left(101 \mathrm{MHz}, \mathrm{CDCl}_{3}\right) \delta 151.4,145.4,135.0,129.6,128.3$, $100.5,85.3,82.8,57.3,41.8,27.7,26.2,26.0,25.9,25.5,25.3,21.6,18.4,11.0$; IR 2929 (m), $2864(\mathrm{~m}), 2360(\mathrm{w}), 2344(\mathrm{w}), 2176(\mathrm{w}), 1783(\mathrm{~s}), 1597(\mathrm{w}), 1495(\mathrm{w}), 1463(\mathrm{w}), 1452(\mathrm{w})$, 1431 (w), 1367 (m), 1320 (w), 1307 (w), 1293 (w), 1254 (w), 1217 (w), 1189 (m), 1174 (s), 1138 (s), 1092 (m), 1046 (w), 1031 (w), 1018 (w), 992 (w), $911(\mathrm{w}), 884(\mathrm{w}), 815$ (w), 758 (w), $736(\mathrm{~m}), 705(\mathrm{w}), 678(\mathrm{~s}), 669(\mathrm{~s}), 633(\mathrm{w}), 620(\mathrm{w}), 606$ (m); Melting Point: 80.0 83.0 ${ }^{\circ} \mathrm{C}$; HRMS (ESI) calcd for $\mathrm{C}_{28} \mathrm{H}_{44} \mathrm{NO}_{4} \mathrm{SSi}^{+}\left(\mathrm{M}+\mathrm{H}^{+}\right)$518.2761; found 518.2759.

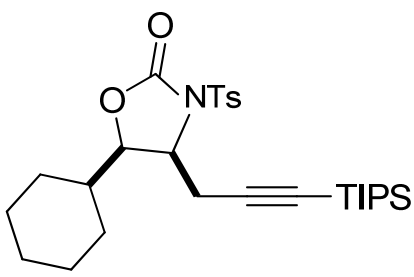

Minor diastereoisomer $(90 \%$ pure due to contamination by the major diastereoisomer): colorless solid (41 mg, $0.080 \mathrm{mmol}, 20 \%$ yield). $\mathrm{R}_{\mathrm{f}} 0.70$ (PET/EtOAc 4/1) ${ }^{1} \mathrm{H}$ NMR (400 MHz, $\left.\mathrm{CDCl}_{3}\right) \delta$ $7.99(\mathrm{~m}, 2 \mathrm{H}$, tosyl $\mathrm{CH}), 7.31(\mathrm{~m}, 2 \mathrm{H}$, tosyl $\mathrm{CH}), 4.53(\mathrm{~m}, 1 \mathrm{H}$, $\mathrm{OCH}), 4.23(\mathrm{dd}, 1 \mathrm{H}, J=10.8,6.6 \mathrm{~Hz}, C H \mathrm{~N}), 2.97(\mathrm{dd}, 1 \mathrm{H}, J=$ 18.0, 4.3 Hz, $\left.\mathrm{CH}_{2} \mathrm{C} \equiv \mathrm{C}\right), 2.59(\mathrm{dd}, 1 \mathrm{H}, J=18.0,2.0 \mathrm{~Hz}$, $\left.\mathrm{CH}_{2} \mathrm{C} \equiv \mathrm{C}\right), 2.49-2.36\left(\mathrm{~m}, 1 \mathrm{H}\right.$, cyclohexane), 2.41 (s, $3 \mathrm{H}$, tosyl $\left.\mathrm{CH}_{3}\right), 2.00(\mathrm{~d}, 1 \mathrm{H}, J=12.9$ $\mathrm{Hz}$, cyclohexane), 1.83-1.50 (m, $5 \mathrm{H}$, cyclohexane), 1.35-0.80 (m, $25 \mathrm{H}$, cyclohexane and TIPS); ${ }^{13} \mathrm{C}$ NMR $\left(101 \mathrm{MHz}, \mathrm{CDCl}_{3}\right) \delta 151.3,145.2,135.2,129.7,128.7,100.5,86.3,82.6$, 58.0, 36.2, 29.3, 29.1, 26.1, 25.1, 24.9, 21.7, 20.3, 18.4, 18.4; IR 2931 (m), 2864 (m), 2361 (w), 2178 (w), 1773 (s), 1597 (w), 1493 (w), 1463 (w), 1453 (w), $1420(\mathrm{w}), 1360$ (s), 1326 (w), $1306(\mathrm{w}), 1295(\mathrm{w}), 1272(\mathrm{w}), 1263(\mathrm{w}), 1236(\mathrm{w}), 1199(\mathrm{~m}), 1174(\mathrm{~s}), 1147(\mathrm{~m}), 1120$ (w), $1102(\mathrm{~s}), 1090(\mathrm{~m}), 1060(\mathrm{w}), 1047(\mathrm{w}), 1028(\mathrm{~m}), 989(\mathrm{w}), 943(\mathrm{w}), 912(\mathrm{w}), 884(\mathrm{~m})$, $842(\mathrm{w}), 815(\mathrm{~m}), 800(\mathrm{w}), 791(\mathrm{w}), 757(\mathrm{~m}), 730(\mathrm{~m}), 704(\mathrm{w}), 668(\mathrm{~s}), 639(\mathrm{w}), 618(\mathrm{~m})$, $608(\mathrm{~m})$; Melting Point: $162.4-164.9^{\circ} \mathrm{C}$; HRMS (ESI) calcd for $\mathrm{C}_{28} \mathrm{H}_{44} \mathrm{NO}_{4} \mathrm{SSi}^{+}\left(\mathrm{M}+\mathrm{H}^{+}\right)$ 518.2761; found 518.2759.

\section{3-Tosyl-4-(3-(triisopropylsilyl)prop-2-ynyl)-1,3-oxazinan-2-one (7d)}

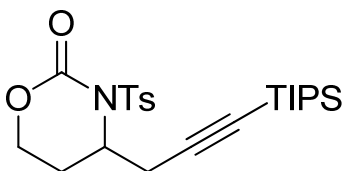

Column chromatography ( $\mathrm{SiO}_{2}$, PET/EtOAc $95 / 5$ to $90 / 10$ ) afforded product 7d (106 mg, $0.236 \mathrm{mmol}, 59 \%$ yield) as a pale yellow oil.

$\mathrm{R}_{\mathrm{f}} 0.45(\mathrm{PET} / \mathrm{EtOAc} 4 / 1) ;{ }^{1} \mathrm{H}$ NMR (400 MHz, $\left.\mathrm{CDCl}_{3}\right) \delta 7.91(\mathrm{~m}, 2$ $\mathrm{H}$, tosyl CH), $7.29(\mathrm{~m}, 2 \mathrm{H}$, tosyl $\mathrm{CH}), 4.71\left(\mathrm{~m}, 1 \mathrm{H}, \mathrm{OCH}_{2}\right.$ or $\left.C H N\right), 4.50(\mathrm{td}, J=11.0,3.0$ $\mathrm{Hz}, \mathrm{OCH}_{2}$ or $\left.C H N\right), 4.28\left(\mathrm{dt}, 1 \mathrm{H}, J=11.3,3.9 \mathrm{~Hz}, \mathrm{OCH}_{2}\right.$ or $\left.C H N\right), 2.97(\mathrm{dd}, 1 \mathrm{H}, J=17.1$, $\left.4.0 \mathrm{~Hz}, \mathrm{CH}_{2} \mathrm{C} \equiv \mathrm{C}\right), 2.77\left(\mathrm{dd}, 1 \mathrm{H}, J=17.1,9.5 \mathrm{~Hz}, \mathrm{CH}_{2} \mathrm{C} \equiv \mathrm{C}\right), 2.55-2.37\left(\mathrm{~m}, 1 \mathrm{H}, \mathrm{OCH}_{2} \mathrm{CH}_{2}\right)$, 2.40 (s, $3 \mathrm{H}$, tosyl $\left.\mathrm{CH}_{3}\right), 2.23\left(\mathrm{~m}, 1 \mathrm{H}, \mathrm{OCH}_{2} \mathrm{CH}_{2}\right), 1.08-0.93$ (m, $\left.21 \mathrm{H}, \mathrm{TIPS}\right) ;{ }^{13} \mathrm{C}$ NMR (101 $\left.\mathrm{MHz}, \mathrm{CDCl}_{3}\right) \delta 148.2,144.9,135.5,129.2,129.0,101.9,85.4,64.3,53.3,25.7,25.6,21.5$, 18.4, 11.0; IR 2957 (w), 2944 (w), 2926 (w), 2901 (w), $2891(w), 2865$ (w), $2361(w), 2342$ 
(w), $2256(\mathrm{w}), 2175(\mathrm{w}), 1734(\mathrm{~s}), 1598(\mathrm{w}), 1507(\mathrm{w}), 1463(\mathrm{w}), 1436(\mathrm{w}), 1410(\mathrm{~m}), 1357$ (m), 1307 (w), 1292 (w), 1271 (m), 1242 (w), 1195 (m), 1185 (m), 1173 (s), 1154 (s), 1087 (m), 1037 (w), $1027(\mathrm{w}), 1017(\mathrm{w}), 999$ (w), $956(\mathrm{w}), 913$ (m), $884(\mathrm{~m}), 827(\mathrm{w}), 814(\mathrm{w})$, $800(\mathrm{w}), 783$ (w), 754 (m), 734 (s), 704 (w), 668 (s), 649 (m), 608 (s); HRMS (ESI) calcd for $\mathrm{C}_{23} \mathrm{H}_{36} \mathrm{NO}_{4} \mathrm{SSi}^{+}\left(\mathrm{M}+\mathrm{H}^{+}\right) 450.2151$; found 450.2134 .

\section{1-Tosyl-5-(3-(triisopropylsilyl)prop-2-ynyl)imidazolidin-2-one (7e)}

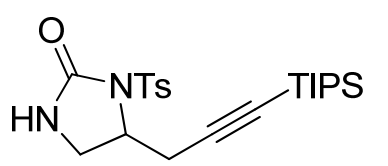

Column chromatography $\left(\mathrm{SiO}_{2}, \mathrm{DCM} /\right.$ EtOAc $\left.95 / 5\right)$ afforded product 7e (137 mg, $0.315 \mathrm{mmol}, 79 \%$ yield) as an off-white amorphous solid.

$\mathrm{R}_{\mathrm{f}} 0.61(\mathrm{DCM} / \mathrm{EtOAc} 10 / 1) ;{ }^{1} \mathrm{H}$ NMR $\left(400 \mathrm{MHz}, \mathrm{CDCl}_{3}\right) \delta 7.87(\mathrm{~m}, 2 \mathrm{H}$, tosyl CH), $7.27(\mathrm{~m}$, $2 \mathrm{H}$, tosyl CH), $6.66(\mathrm{~s}, 1 \mathrm{H}, \mathrm{NH}), 4.41(\mathrm{~m}, 1 \mathrm{H}, \mathrm{CHN}), 3.56\left(\mathrm{t}, 1 \mathrm{H}, J=9.0 \mathrm{~Hz}, \mathrm{HNCH}_{2}\right)$, $3.42\left(\mathrm{dd}, 1 \mathrm{H}, J=9.0,4.0 \mathrm{~Hz}, \mathrm{HNCH}_{2}\right), 2.87$ (dd, $\left.1 \mathrm{H}, J=17.1,3.5 \mathrm{~Hz}, \mathrm{CH}_{2} \mathrm{C} \equiv \mathrm{C}\right), 2.74$ (dd, $\left.1 \mathrm{H}, J=17.1,8.0 \mathrm{~Hz}, \mathrm{CH}_{2} \mathrm{C} \equiv \mathrm{C}\right), 2.38\left(\mathrm{~s}, 3 \mathrm{H}\right.$, tosyl $\left.\mathrm{CH}_{3}\right), 1.07-0.90(\mathrm{~m}, 21 \mathrm{H}, \mathrm{TIPS}) ;{ }^{13} \mathrm{C}$ NMR $\left(101 \mathrm{MHz}, \mathrm{CDCl}_{3}\right) \delta 155.9,144.4,136.1,129.4,127.7,101.7,84.2,55.2,42.6,26.2$, 21.4, 18.4, 11.0; IR 3268 (w), 3143 (w), 2943 (w), 2892 (w), $2865(\mathrm{~m}), 2361(\mathrm{w}), 2342(\mathrm{w})$, $2256(\mathrm{w}), 2176(\mathrm{w}), 1738(\mathrm{~s}), 1598(\mathrm{w}), 1489$ (w), 1463 (w), $1431(\mathrm{w}), 1363$ (m), 1362 (m), 1318 (w), 1309 (w), 1282 (w), 1255 (w), 1188 (w), 1169 (s), 1134 (w), 1090 (m), 1063 (m), 1018 (w), $997(\mathrm{w}), 981(\mathrm{w}), 910(\mathrm{~s}), 884(\mathrm{~m}), 814(\mathrm{w}), 801(\mathrm{w}), 764(\mathrm{w}), 731$ (s), 705 (m), $678(\mathrm{~s}), 668(\mathrm{~s}), 650(\mathrm{~m}), 633(\mathrm{~m}), 607(\mathrm{w})$; HRMS (ESI) calcd for $\mathrm{C}_{22} \mathrm{H}_{35} \mathrm{~N}_{2} \mathrm{O}_{3} \mathrm{SSi}^{+}\left(\mathrm{M}+\mathrm{H}^{+}\right)$ 445.2138; found 435.2153 .

\section{1-Allyl-3-tosyl-4-(3-(triisopropylsilyl)prop-2-ynyl)imidazolidin-2-one (7f)}

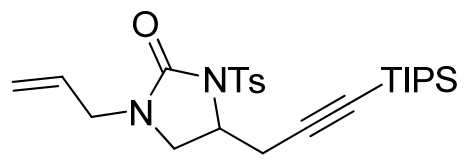

Column chromatography $\left(\mathrm{SiO}_{2}, \mathrm{PET} /\right.$ EtOAc 9/1) afforded product $7 \mathbf{f}(127 \mathrm{mg}, 0.268 \mathrm{mmol}, 67 \%$ yield) as a yellow oil.

$\mathrm{R}_{\mathrm{f}} 0.65$ (PET/EtOAc 9/1); ${ }^{1} \mathrm{H}$ NMR (400 MHz, $\left.\mathrm{CDCl}_{3}\right) \delta 7.95$ (m, $2 \mathrm{H}$, tosyl CH), $7.30(\mathrm{~m}, 2 \mathrm{H}$, tosyl $\mathrm{CH}), 5.66(\mathrm{ddt}, 1 \mathrm{H}, J=$ 16.7, 10.1, $6.4 \mathrm{~Hz}, \mathrm{CH}_{2} \mathrm{CH}=\mathrm{CH}_{2}$ ), 5.22-5.13 (m, $2 \mathrm{H}, \mathrm{CH}_{2} \mathrm{CH}=\mathrm{CH}_{2}$ ), 4.44 (ddt, $1 \mathrm{H}, J=9.3$, 7.9, 4.0 Hz, NCH), $3.76\left(\mathrm{~m}, 2 \mathrm{H}, \mathrm{CH}_{2} \mathrm{CH}=\mathrm{CH}_{2}\right), 3.52$ (t, $\left.1 \mathrm{H}, J=9.3 \mathrm{~Hz}, \mathrm{NCHCH}_{2}\right), 3.35$ $\left(\mathrm{dd}, 1 \mathrm{H}, J=9.3,4.2 \mathrm{~Hz}, \mathrm{NCHCH}_{2}\right), 2.91\left(\mathrm{dd}, 1 \mathrm{H}, J=16.9,3.6 \mathrm{~Hz}, \mathrm{CH}_{2} \mathrm{C} \equiv \mathrm{C}\right), 2.81(\mathrm{dd}, 1$ $\left.\mathrm{H}, J=16.9,7.7 \mathrm{~Hz}, \mathrm{CH}_{2} \mathrm{C} \equiv \mathrm{C}\right), 2.42\left(\mathrm{~s}, 3 \mathrm{H}\right.$, tosyl $\left.\mathrm{CH}_{3}\right), 1.17-0.83(\mathrm{~m}, 21 \mathrm{H}, \mathrm{TIPS}) ;{ }^{13} \mathrm{C}$ NMR $\left(101 \mathrm{MHz}, \mathrm{CDCl}_{3}\right) \delta 153.1,144.4,136.1,131.5,129.4,128.1,119.0,101.7,84.4,52.2,46.3$, 46.1, 26.1, 21.5, 18.4, 11.0; IR 3075 (w), 2943 (m), 2891 (w), 2865 (m), 2363 (w), 2256 (w), $2175(\mathrm{w}), 1733$ (s), 1646 (w), $1629(\mathrm{w}), 1598$ (w), $1489(\mathrm{w}), 1462$ (w), 1439 (m), 1418 (m), 1357 (m), 1307 (w), $1291(\mathrm{w}), 1290(\mathrm{w}), 1264(\mathrm{~m}), 1212(\mathrm{w}), 1188(\mathrm{~m}), 1168(\mathrm{~s}), 1143(\mathrm{~m})$, 1120 (m), 1093 (m), 1074 (w), 1055 (w), 1029 (w), 1019 (w), 995 (m), 968 (w), 918 (m), 884 (m), $814(\mathrm{~m}), 801(\mathrm{w}), 778(\mathrm{w}), 754(\mathrm{~m}), 740(\mathrm{~m}), 732(\mathrm{~m}), 706(\mathrm{w}), 698(\mathrm{w}), 667$ (s), 635 $(\mathrm{w}), 627(\mathrm{w}), 620(\mathrm{w}), 612(\mathrm{w})$. HRMS (ESI) calculated for $\mathrm{C}_{25} \mathrm{H}_{39} \mathrm{~N}_{2} \mathrm{O}_{3} \mathrm{SSi}^{+}\left(\mathrm{M}+\mathrm{H}^{+}\right)$ 475.2451; found 475.2454 .

\section{1-Benzyl-3-tosyl-4-(3-(triisopropylsilyl)prop-2-ynyl)imidazolidin-2-one (7g)}

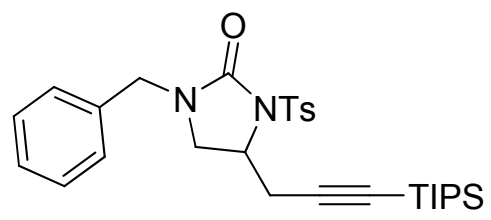


Column chromatography $\left(\mathrm{SiO}_{2}\right.$, PET/EtOAc 9/1) afforded product $7 \mathbf{g}(137 \mathrm{mg}, 0.261 \mathrm{mmol}$, $65 \%$ yield) as a brownish oil.

$\mathrm{R}_{\mathrm{f}} 0.55\left(\mathrm{PET} /\right.$ EtOAc 9/1); ${ }^{1} \mathrm{H}$ NMR (400 MHz, $\left.\mathrm{CDCl}_{3}\right) \delta 7.97$ (m, $2 \mathrm{H}$, tosyl CH), 7.40-7.23 $\left(\mathrm{m}, 6 \mathrm{H}\right.$, tosyl $\mathrm{CH}$ and $\left.\mathrm{NCH}_{2} P h\right), 7.14\left(\mathrm{~m}, 2 \mathrm{H}, \mathrm{NCH}_{2} P h\right), 4.45(\mathrm{~d}, 1 \mathrm{H}, J=14.8 \mathrm{~Hz}$, $\left.\mathrm{NCH}_{2} \mathrm{Ph}\right), 4.38(\mathrm{~m}, 1 \mathrm{H}, \mathrm{NCH}), 4.16\left(\mathrm{~d}, 1 \mathrm{H}, J=14.7 \mathrm{~Hz}, \mathrm{NCH}_{2} \mathrm{Ph}\right), 3.39$ (t, $1 \mathrm{H}, J=9.3 \mathrm{~Hz}$, $\mathrm{NCH}_{2}$ ), 3.25 (dd, $1 \mathrm{H}, J=9.3,4.1 \mathrm{~Hz}, \mathrm{NCH}_{2}$ ), 2.90 (dd, $1 \mathrm{H}, J=16.9,3.6 \mathrm{~Hz}, \mathrm{CH}_{2} \mathrm{C} \equiv \mathrm{C}$ ), $2.74\left(\mathrm{dd}, 1 \mathrm{H}, J=16.8,8.1 \mathrm{~Hz}, \mathrm{CH}_{2} \mathrm{C} \equiv \mathrm{C}\right), 2.44\left(\mathrm{~s}, 3 \mathrm{H}\right.$, tosyl $\left.\mathrm{CH}_{3}\right), 1.05-0.90(\mathrm{~m}, 21 \mathrm{H}$, TIPS); ${ }^{13} \mathrm{C}$ NMR (101 MHz, $\left.\mathrm{CDCl}_{3}\right) \delta 153.5,144.6,136.2,135.2,129.6,128.8,128.3,128.0$, 101.8, 84.5, 52.4, 47.7, 46.4, 26.3, 21.7, 18.6, 11.1; ${ }^{[29]}$ IR 2942 (m), $2865(\mathrm{~m}), 2176(\mathrm{w})$, 1735 (s), 1598 (w), 1495 (w), 1462 (w), 1440 (m), 1365 (m), 1265 (w), 1210 (w), 1170 (s), 1119 (m), 1093 (m), 1056 (w), 997 (w), 912 (w), 885 (w), 815 (w), 757 (m), 703 (m), 670 (s). HRMS (ESI) calculated for $\mathrm{C}_{29} \mathrm{H}_{41} \mathrm{~N}_{2} \mathrm{O}_{3} \mathrm{SSi}^{+}\left(\mathrm{M}+\mathrm{H}^{+}\right)$525.2607; found 525.2592.

\section{5-methyl-1-(4-nitrophenylsulfonyl)-5-(3-(triisopropylsilyl)prop-2-ynyl)pyrrolidin-2-one (3m)}
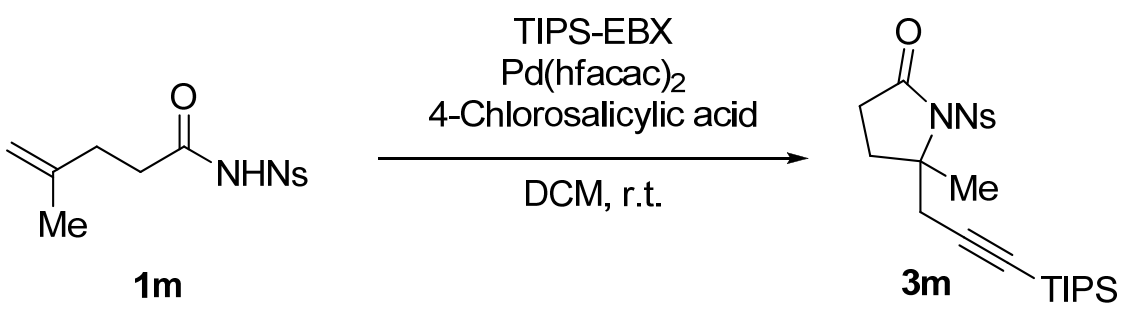

TIPS-EBX (2a) (206 mg, $0.480 \mathrm{mmol}, 1.20$ equiv) was added to a solution of nosyl amide $1 \mathrm{~m}$ (119 mg, $0.400 \mathrm{mmol}, 1.00$ equiv) and $\mathrm{Pd}(\mathrm{hfacac})_{2}(21 \mathrm{mg}, 0.040 \mathrm{mmol}, 0.10$ equiv) in DCM (10 mL). 4-Chlorosalicylic acid ( $83 \mathrm{mg}, 0.48 \mathrm{mmol}, 1.2$ equiv) was added and the mixture was stirred at room temperature overnight. The solvent was then evaporated under reduced pressure and the residue was diluted in $\mathrm{Et}_{2} \mathrm{O}(10 \mathrm{~mL})$ and washed with a saturated solution of $\mathrm{Na}_{2} \mathrm{CO}_{3}(10 \mathrm{~mL})$. The aqueous layer was extracted with $\mathrm{Et}_{2} \mathrm{O}(3 \times 10 \mathrm{~mL})$ and the combined organic layers were dried over $\mathrm{MgSO}_{4}$, filtered and concentrated in vacuo. Purification by column chromatography $\left(\mathrm{SiO}_{2}\right.$, hexane/EtOAc $95 / 5$ to $\left.90 / 10\right)$ afforded 5methyl-1-(4-nitrophenylsulfonyl)-5-(3-(triisopropylsilyl)prop-2-ynyl)pyrrolidin-2-one (3m) (118 mg, $0.246 \mathrm{mmol}, 62 \%$ yield) as a yellow solid.

$\mathrm{R}_{\mathrm{f}} 0.61\left(\mathrm{PET} / \mathrm{EtOAc} / \mathrm{AcOH}\right.$ 15/5/0.2); ${ }^{1} \mathrm{H}$ NMR $\left(400 \mathrm{MHz}, \mathrm{CDCl}_{3}\right) \delta$ 8.39-8.26 (m, $4 \mathrm{H}$, Nosyl CH), $3.19\left(\mathrm{~d}, 1 \mathrm{H}, J=17.1 \mathrm{~Hz}, \mathrm{CH}_{2} \mathrm{C} \equiv \mathrm{C}\right), 2.91\left(\mathrm{~d}, 1 \mathrm{H}, J=17.1 \mathrm{~Hz}, \mathrm{CH}_{2} \mathrm{C} \equiv \mathrm{C}\right), 2.60$ (m, $\left.1 \mathrm{H}, \mathrm{COCH}_{2} \mathrm{CH}_{2}\right), 2.44\left(\mathrm{~m}, 2 \mathrm{H}, \mathrm{COCH}_{2} \mathrm{CH}_{2}\right), 2.00\left(\mathrm{~m}, 1 \mathrm{H}, \mathrm{COCH}_{2} \mathrm{CH}_{2}\right), 1.78(\mathrm{~s}, 3 \mathrm{H}$, $\mathrm{Me}), 1.07-0.91$ (m, $21 \mathrm{H}, \mathrm{TIPS}) ;{ }^{13} \mathrm{C} \mathrm{NMR}\left(101 \mathrm{MHz}, \mathrm{CDCl}_{3}\right) \delta 174.2,150.5,144.2,130.5$, 123.7, 103.0, 85.0, 69.0, 32.7, 32.1, 29.8, 27.7, 18.5, 11.1; IR 3108 (w), 2944 (m), $2892(\mathrm{w})$, 2866 (m), $2174(\mathrm{w}), 1742$ (s), 1608 (w), 1535 (s), 1464 (w), 1404 (w), 1367 (s), 1352 (s), $1315(\mathrm{w}), 1282(\mathrm{~m}), 1243(\mathrm{w}), 1212(\mathrm{~m}), 1198(\mathrm{~m}), 1178$ (s), 1141 (m), $1108(\mathrm{~m}), 1088(\mathrm{~m})$, 1045 (w), 1014 (w), 999 (w), 959 (w), 944 (m), 912 (w), $885(\mathrm{w}), 856(\mathrm{~m}), 840(\mathrm{w}), 819(\mathrm{w})$, $812(\mathrm{w}), 779(\mathrm{w}), 741(\mathrm{~s}), 711(\mathrm{w}), 711(\mathrm{w}), 684(\mathrm{~s}), 666(\mathrm{~m}), 653(\mathrm{~m}), 643(\mathrm{~m}), 633$ (m), 626

[29] One ${ }^{13} \mathrm{C}$ signal could not be resolved. 
(m), 608 (m); Melting point: $117.5-119.7^{\circ} \mathrm{C}$; HRMS (ESI) calcd for $\mathrm{C}_{23} \mathrm{H}_{35} \mathrm{~N}_{2} \mathrm{O}_{5} \mathrm{SSi}^{+}$ $\left(\mathrm{M}+\mathrm{H}^{+}\right)$479.2030; found 479.2041.

\section{Deprotection and Second Cyclization}

\section{5-(Prop-2-ynyl)pyrrolidin-2-one (8a)}

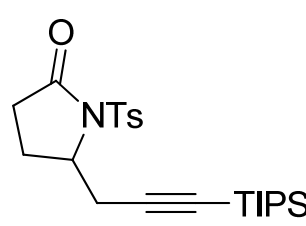

$3 a$
(1)

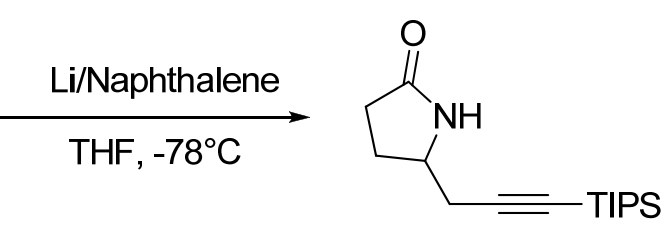

58

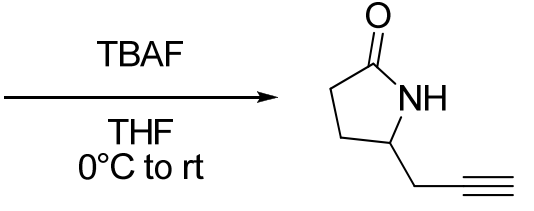

$8 \mathbf{a}$

Following a slightly modified version of a reported procedure, ${ }^{[30]}$ naphthalene $(4.48 \mathrm{~g}, 35.0$ mmol) was dissolved in previously degassed THF (70 mL). Lithium $(250 \mathrm{mg}, 35.0 \mathrm{mmol})$ was added and the mixture was sonicated for $30 \mathrm{~min}$ and then stirred at room temperature for $2 \mathrm{~h}$ in order to obtain a $0.5 \mathrm{M}$ dark green Li-naphthalenide solution. $N$-tosyl lactam $3 \mathrm{a}(2.40 \mathrm{~g}$, $5.53 \mathrm{mmol})$ was dissolved in THF $(11.5 \mathrm{~mL})$ and the resulting solution was cooled to $-78^{\circ} \mathrm{C}$. The Li-naphthalenide was then added dropwise until the reaction mixture stayed permanently dark green (ca $40 \mathrm{~mL}$, ca 4.0 equiv). The mixture was stirred at $-78^{\circ} \mathrm{C}$ for $30 \mathrm{~min}$ and at room temperature for $30 \mathrm{~min}$, before quenching with $1 \mathrm{M} \mathrm{NaHCO}_{3}$ (ca $10 \mathrm{~mL}$ ). The aqueous layer was extracted with EtOAc $(3 \times 15 \mathrm{~mL})$. The combined organic layers were dried over $\mathrm{MgSO}_{4}$, filtered and concentrated in vacuo. Purification by column chromatography $\left(\mathrm{SiO}_{2}\right.$, PET/EtOAc 80/20 to 33/66) afforded 5-(3-(triisopropylsilyl)prop-2-ynyl)pyrrolidin-2-one (58) $(1.51 \mathrm{~g}, 5.40 \mathrm{mmol}, 97 \%$ yield as a yellow oil).

Following a reported procedure, ${ }^{[19]}$ 5-(3-(triisopropylsilyl)prop-2-ynyl)pyrrolidin-2-one (58) $(1.51 \mathrm{~g}, 5.40 \mathrm{mmol}, 1.0$ equiv) was dissolved in THF $(25 \mathrm{~mL})$ and the resulting solution was cooled to $0^{\circ} \mathrm{C}$. TBAF (1.0 M in THF) $(10.8 \mathrm{~mL}, 10.8 \mathrm{mmol}, 2.0$ equiv) was added dropwise and the mixture was allowed to warm to room temperature over $2 \mathrm{~h} .1 \mathrm{M} \mathrm{NaHCO}_{3}$ was then added (ca $25 \mathrm{~mL})$. The aqueous layer was extracted with EtOAc $(6 \times 25 \mathrm{~mL})$. The combined organic layers were dried over $\mathrm{MgSO}_{4}$, filtered and concentrated in vacuo. Purification by column chromatography $\left(\mathrm{SiO}_{2}, \quad \mathrm{DCM}\right.$ to $\mathrm{DCM} / \mathrm{MeOH}$ 97/3) afforded 5-(prop-2ynyl)pyrrolidin-2-one (8a) (578 $\mathrm{mg}, 4.69 \mathrm{mmol}, 87 \%$ yield) as a pale yellow solid.

$\mathrm{R}_{\mathrm{f}} 0.28\left(\mathrm{DCM} / \mathrm{EtOAc} \mathrm{1/1);}{ }^{1} \mathrm{H}\right.$ NMR $\left(400 \mathrm{MHz}, \mathrm{CDCl}_{3}\right) \delta 6.91$ (br s, $\left.1 \mathrm{H}, \mathrm{NH}\right), 3.80(\mathrm{~m}, 1 \mathrm{H}$, $\mathrm{NCH}), 2.54-2.19\left(\mathrm{~m}, 5 \mathrm{H}, \mathrm{COCH}_{2} \mathrm{CH}_{2}\right.$ and $\left.\mathrm{CH}_{2} \mathrm{C} \equiv \mathrm{CH}\right), 2.01\left(\mathrm{t}, 1 \mathrm{H}, \mathrm{J}=2.4 \mathrm{~Hz}, \mathrm{CH}_{2} \mathrm{C} \equiv \mathrm{CH}\right)$, $1.85\left(\mathrm{~m}, 1 \mathrm{H}, \mathrm{COCH}_{2} \mathrm{CH}_{2}\right) ;{ }^{13} \mathrm{C} \mathrm{NMR}\left(101 \mathrm{MHz}, \mathrm{CDCl}_{3}\right) \delta 178.2,79.9,70.7,53.0,29.9$, 26.1, 26.0; IR 3210 (m), 3098 (w), 2939 (w), 1677 (s), 1465 (w), 1464 (w), 1436 (w), 1389 (w), $1348(\mathrm{w}), 1322(\mathrm{w}), 1294(\mathrm{w}), 1269(\mathrm{w}), 843(\mathrm{w}), 818(\mathrm{w}), 798(\mathrm{w}), 785(\mathrm{w}), 762(\mathrm{w})$, $733(\mathrm{~m}), 707(\mathrm{w}), 672(\mathrm{w}), 659(\mathrm{w}), 645(\mathrm{w}), 633(\mathrm{w})$; Melting point: $108.7-111.2^{\circ} \mathrm{C}$; HRMS (ESI) calcd for $\mathrm{C}_{7} \mathrm{H}_{10} \mathrm{NO}^{+}\left(\mathrm{M}+\mathrm{H}^{+}\right)$124.0762; found 124.0763. 
4-(Prop-2-ynyl)oxazolidin-2-one (8b)

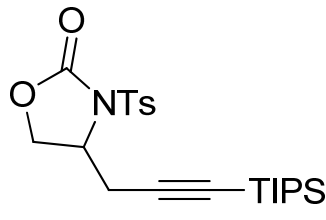

$7 a$

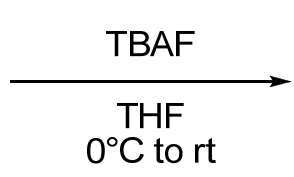

$0^{\circ} \mathrm{C}$ to rt

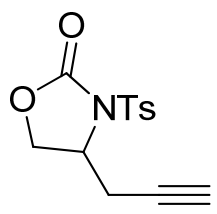

59

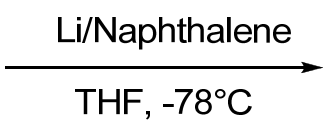

$8 b$

Following a reported procedure, ${ }^{[19]}$ the $N$-tosyl carbamate $7 \mathbf{a}(1.0 \mathrm{~g}, 2.3 \mathrm{mmol}, 1.0$ equiv) was dissolved in THF $(11 \mathrm{~mL})$ and the resulting solution was cooled to $0^{\circ} \mathrm{C}$. TBAF $(1.0 \mathrm{M}$ in THF) (4.6 mL, $4.6 \mathrm{mmol}, 2.0$ equiv) was added dropwise and the mixture was allowed to warm to room temperature over $2 \mathrm{~h} .1 \mathrm{M} \mathrm{NaHCO}_{3}$ was then added (ca $10 \mathrm{~mL}$ ). The aqueous layer was extracted with EtOAc $(6 \times 10 \mathrm{~mL})$. The combined organic layers were dried over $\mathrm{MgSO}_{4}$, filtered and concentrated in vacuo. Purification by column chromatography $\left(\mathrm{SiO}_{2}\right.$, DCM) afforded 4-(prop-2-ynyl)-3-tosyloxazolidin-2-one (59) (388 mg, 1.39 mmol, 60 \% yield) as a colorless solid.

Following a slightly modified version of a reported procedure, ${ }^{[30]}$ naphthalene $(4.48 \mathrm{~g}, 35.0$ mmol) was dissolved in previously degassed THF (70 mL). Lithium $(250 \mathrm{mg}, 35.0 \mathrm{mmol})$ was added and the mixture was sonicated for $30 \mathrm{~min}$ and then stirred at room temperature for $2 \mathrm{~h}$ in order to obtain a $0.5 \mathrm{M}$ dark green Li-naphthalenide solution. $\mathrm{N}$-tosyl carbamate 59 $(388 \mathrm{mg}, 1.39 \mathrm{mmol})$ was dissolved in THF $(2.9 \mathrm{~mL})$ and the resulting solution was cooled to $-78^{\circ} \mathrm{C}$. The Li-naphthalenide was then added dropwise until the reaction mixture stayed permanently dark green (ca $11 \mathrm{~mL}$, ca 4.0 equiv). The mixture was stirred at $-78^{\circ} \mathrm{C}$ for 30 min and at room temperature for $30 \mathrm{~min}$, before being quenched with $1 \mathrm{M} \mathrm{NaHCO}_{3}$ (ca 5 $\mathrm{mL})$. The aqueous layer was extracted with EtOAc $(3 \times 10 \mathrm{~mL})$. The combined organic layers were dried over $\mathrm{MgSO}_{4}$, filtered and concentrated in vacuo. Purification by column chromatography $\left(\mathrm{SiO}_{2}, \mathrm{DCM}\right.$ to $\mathrm{DCM} / \mathrm{MeOH}$ 98/2) afforded 4-(prop-2-ynyl)oxazolidin-2one (8b) (155 mg, $1.24 \mathrm{mmol}, 87 \%$ yield) as a yellow solid.

$\mathrm{R}_{\mathrm{f}} 0.40(\mathrm{DCM} / \mathrm{MeOH} 95 / 5) ;{ }^{1} \mathrm{H}$ NMR $\left(400 \mathrm{MHz}, \mathrm{CDCl}_{3}\right) \delta 5.72($ br s, $1 \mathrm{H}, \mathrm{NH}), 4.53(\mathrm{t}, 1 \mathrm{H}$, $\left.J=8.6 \mathrm{~Hz}, \mathrm{OCH}_{2}\right), 4.20(\mathrm{dd}, 1 \mathrm{H}, J=8.9,4.9 \mathrm{~Hz}, \mathrm{NCH}), 4.04\left(\mathrm{~m}, 1 \mathrm{H}, \mathrm{OCH}_{2}\right), 2.48(\mathrm{dd}, 2 \mathrm{H}$, $\left.J=6.2,2.6 \mathrm{~Hz}, \mathrm{CH}_{2} \mathrm{C} \equiv \mathrm{CH}\right), 2.08\left(\mathrm{t}, 1 \mathrm{H}, J=2.6 \mathrm{~Hz}, \mathrm{CH}_{2} \mathrm{C} \equiv \mathrm{CH}\right) ;{ }^{13} \mathrm{C}$ NMR $(101 \mathrm{MHz}$, $\left.\mathrm{CDCl}_{3}\right) \delta$ 159.0, 78.2, 71.6, 69.2, 51.1, 25.2; IR $3369(\mathrm{w}), 3294(\mathrm{w}), 3287(\mathrm{w}), 2916(\mathrm{w})$, $2135(\mathrm{w}), 1751(\mathrm{~s}), 1651(\mathrm{w}), 1630(\mathrm{w}), 1611(\mathrm{w}), 1480(\mathrm{w}), 1454(\mathrm{w}), 1410(\mathrm{~m}), 1359(\mathrm{w})$, 1346 (w), 1330 (w), 1323 (w), 1288 (w), 1251 (w), 1205 (w), 1104 (w), 1075 (w), 1026 (m), $932(\mathrm{w}), 786(\mathrm{w}), 771(\mathrm{w}), 747(\mathrm{w}), 739(\mathrm{w}), 729(\mathrm{w}), 709(\mathrm{w}), 681(\mathrm{~m}), 669(\mathrm{~m}), 637(\mathrm{~m})$, 629 (w), $612(\mathrm{w})$; Melting point: $72.3-74.6^{\circ} \mathrm{C}$; HRMS (ESI) calcd for $\mathrm{C}_{6} \mathrm{H}_{8} \mathrm{NO}_{2}{ }^{+}\left(\mathrm{M}+\mathrm{H}^{+}\right)$ 126.0555; found 126.0556 .

\section{6-(Prop-2-ynyl)piperidin-2-one (8c)}




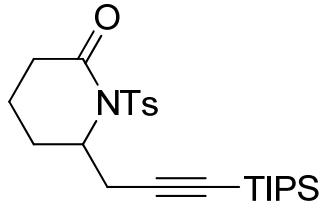

$3 \mathbf{i}$

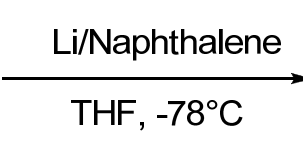

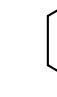

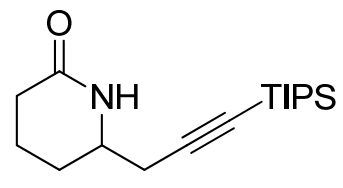

60

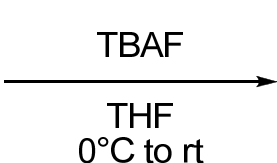

$0^{\circ} \mathrm{C}$ to rt

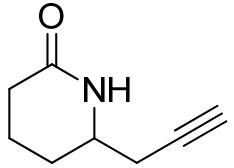

8c

Following a slightly modified version of a reported procedure, ${ }^{[30]}$ naphthalene $(4.48 \mathrm{~g}, 35.0$ $\mathrm{mmol})$ was dissolved in previously degassed THF $(70 \mathrm{~mL})$. Lithium $(250 \mathrm{mg}, 35.0 \mathrm{mmol})$ was added and the mixture was sonicated for $30 \mathrm{~min}$ and then stirred at room temperature for $2 \mathrm{~h}$ in order to obtain a $0.5 \mathrm{M}$ dark green Li-naphthalenide solution. $N$-tosyl lactam $3 \mathbf{i}$ (630 $\mathrm{mg}, 1.41 \mathrm{mmol})$ was dissolved in THF $(2.5 \mathrm{~mL})$ and the resulting solution was cooled to $78^{\circ} \mathrm{C}$. The Li-naphthalenide was then added dropwise until the reaction mixture stayed permanently dark green (ca $10 \mathrm{~mL}$, ca 4.0 equiv). The mixture was stirred at $-78^{\circ} \mathrm{C}$ for 30 min and at room temperature for $30 \mathrm{~min}$, before quenching with $1 \mathrm{M} \mathrm{NaHCO}_{3}$ (ca $5 \mathrm{~mL}$ ). The aqueous layer was extracted with EtOAc $(3 \times 10 \mathrm{~mL})$. The combined organic layers were dried over $\mathrm{MgSO}_{4}$, filtered and concentrated in vacuo. Purification by column chromatography $\left(\mathrm{SiO}_{2}\right.$, PET/EtOAc 80/20 to 0/100) afforded 6-(3-(triisopropylsilyl)prop-2ynyl)piperidin-2-one (60) (356 mg, $1.21 \mathrm{mmol}, 87 \%$ yield) as a colorless solid.

Following a reported procedure, ${ }^{[19]}$ 6-(3-(triisopropylsilyl)prop-2-ynyl)piperidin-2-one (64) (356 mg, $1.21 \mathrm{mmol}, 1.0$ equiv) was dissolved in THF $(5.6 \mathrm{~mL})$ and the resulting solution was cooled to $0^{\circ} \mathrm{C}$. TBAF (1.0 M in THF) $(2.5 \mathrm{~mL}, 2.5 \mathrm{mmol}, 2.0$ equiv) was added dropwise and the mixture was allowed to warm to room temperature over $2 \mathrm{~h} .1 \mathrm{M} \mathrm{NaHCO}_{3}$ was then added (ca $10 \mathrm{~mL})$. The aqueous layer was extracted with EtOAc $(6 \times 10 \mathrm{~mL})$. The combined organic layers were dried over $\mathrm{MgSO}_{4}$, filtered and concentrated in vacuo. Purification by column chromatography $\left(\mathrm{SiO}_{2}, \quad \mathrm{DCM}\right.$ to $\mathrm{DCM} / \mathrm{MeOH}$ 97/3) afforded 6-(prop-2ynyl)piperidin-2-one (8c) (157 mg, $1.14 \mathrm{mmol}$, 94\% yield) as a pale yellow solid.

$\mathrm{R}_{\mathrm{f}} 0.30$ (DCM/MeOH 40/1); ${ }^{1} \mathrm{H}$ NMR (400 MHz, $\mathrm{CD}_{2} \mathrm{Cl}_{2}$ ) $\delta 5.96$ (br s, $\left.1 \mathrm{H}, N H\right), 3.56$ (m, 1 $\mathrm{H}, \mathrm{NCH}), 2.44\left(\mathrm{ddd}, 1 \mathrm{H}, J=16.6,5.5,2.5 \mathrm{~Hz}, \mathrm{CH}_{2} \mathrm{C} \equiv \mathrm{CH}\right), 2.40-2.21\left(\mathrm{~m}, 3 \mathrm{H}, \mathrm{CH}_{2} \mathrm{C} \equiv \mathrm{CH}\right.$ and $\left.\mathrm{COCH}_{2} \mathrm{CH}_{2} \mathrm{CH}_{2}\right), 2.17$ (t, $\left.1 \mathrm{H}, J=2.6 \mathrm{~Hz}, \mathrm{CH}_{2} \mathrm{C} \equiv \mathrm{CH}\right), 2.06-1.87(\mathrm{~m}, 2 \mathrm{H}$, $\left.\mathrm{COCH}_{2} \mathrm{CH}_{2} \mathrm{CH}_{2}\right), 1.74\left(\mathrm{~m}, 1 \mathrm{H}, \mathrm{COCH}_{2} \mathrm{CH}_{2} \mathrm{CH}_{2}\right), 1.49\left(\mathrm{~m}, 1 \mathrm{H}, \mathrm{COCH}_{2} \mathrm{CH}_{2} \mathrm{CH}_{2}\right) ;{ }^{13} \mathrm{C} \mathrm{NMR}$ $\left(101 \mathrm{MHz}, \mathrm{CD}_{2} \mathrm{Cl}_{2}\right) \delta 171.4,79.9,71.1,51.8,31.4,28.1,26.6,19.6$; IR $3286(\mathrm{~m}), 3260(\mathrm{w})$, $3228(\mathrm{~m}), 3227(\mathrm{~m}), 3077(\mathrm{w}), 2953(\mathrm{~m}), 2879(\mathrm{w}), 1655(\mathrm{~s}), 1484(\mathrm{w}), 1452(\mathrm{w}), 1409(\mathrm{~m})$, $1348(\mathrm{~m}), 1315(\mathrm{w}), 1292(\mathrm{w}), 1291(\mathrm{w}), 1225(\mathrm{w}), 1191(\mathrm{w}), 1156(\mathrm{w}), 1133(\mathrm{w}), 1132(\mathrm{w})$, $1080(\mathrm{w}), 957(\mathrm{w}), 866(\mathrm{w}), 836(\mathrm{w}), 813(\mathrm{w}), 771(\mathrm{w}), 714(\mathrm{w}), 700(\mathrm{w}), 661(\mathrm{~m}), 654(\mathrm{~m})$, $620(w)$; Melting point: $98.0-100.4^{\circ} \mathrm{C}$; HRMS (ESI) calcd for $\mathrm{C}_{8} \mathrm{H}_{12} \mathrm{NO}^{+}\left(\mathrm{M}+\mathrm{H}^{+}\right)$138.0919; found 138.0923 .

4-(Benzyloxymethyl)-1-tosyl-5-(3-(triisopropylsilyl)prop-2-ynyl)pyrrolidin-2-one (12) 
<smiles>OC/C=C\COc1ccccc1</smiles>

10

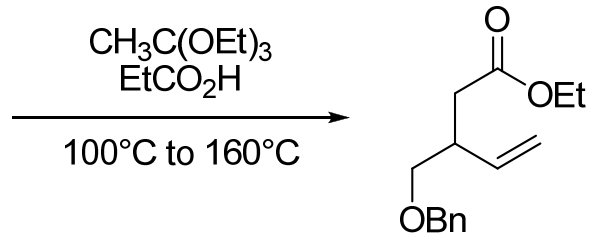

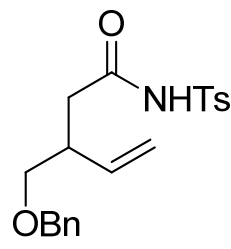

11
61
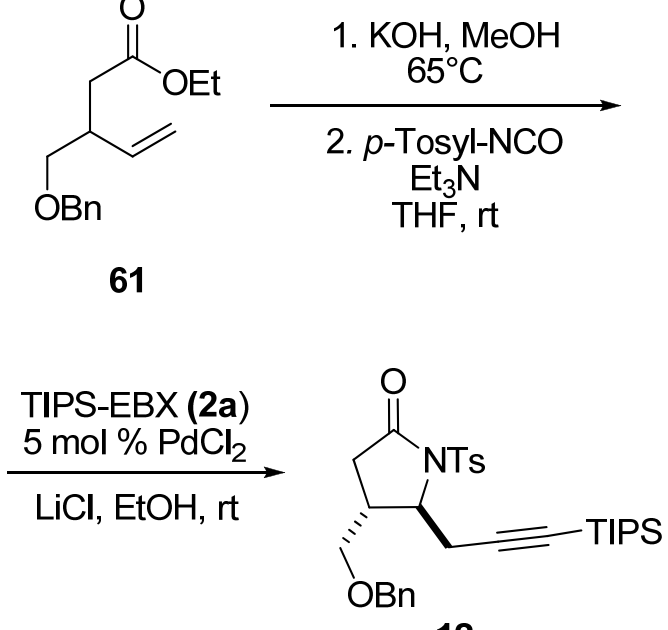

12

Following a reported procedure, ${ }^{[31]}$ cis-4-benzyloxy-2-buten-1-ol (10) (4.00 g, 22.4 mmol, 1.00 equiv) was mixed with triethyl orthoacetate $(20.4 \mathrm{~mL}, 112 \mathrm{mmol}, 5.00$ equiv) and propionic acid $\left(0.167 \mathrm{~mL}, 2.24 \mathrm{mmol}, 0.10\right.$ equiv). The mixture was heated to $100^{\circ} \mathrm{C}$ until the complete distillation of $\mathrm{EtOH}$ and then to $160^{\circ} \mathrm{C}$ until full conversion was observed by TLC (ca $4 \mathrm{~h}$ ). After this time, triethyl orthoacetate was removed by distillation under reduced pressure to afford the ester $\mathbf{6 5}$ as an orange oil. The latter was dissolved in $\mathrm{MeOH}(25 \mathrm{~mL})$ and $\mathrm{KOH}(3.1 \mathrm{~g}, 56 \mathrm{mmol})$ was added. The mixture was refluxed for $4 \mathrm{~h}$; it was then allowed to cool to room temperature, diluted with water $(50 \mathrm{~mL})$, washed with $\mathrm{Et}_{2} \mathrm{O}(3 \times 50 \mathrm{~mL})$ and acidified to $\mathrm{pH} 1$ by slow addition of $37 \% \mathrm{HCl}$. The aqueous layer was extracted with DCM ( $3 \times 50 \mathrm{~mL}$ ) and the combined organic layers were dried over $\mathrm{MgSO}_{4}$, filtered and concentrated in vacuo to afford pure 3-(benzyloxymethyl)pent-4-enoic acid (3.93 g, 17.8 mmol, 80\% yield over two steps) as a viscous yellow oil.

Following a reported procedure, ${ }^{[7]} p$-tosyl isocyanate $(2.69 \mathrm{~g}, 13.6 \mathrm{mmol}, 1.00$ equiv) was added to a solution of 3-(benzyloxymethyl)pent-4-enoic acid (3.00 g, $13.6 \mathrm{mmol}, 1.00$ equiv) in THF $(42 \mathrm{~mL})$. After stirring the resulting clear solution at room temperature for $10 \mathrm{~min}$, triethylamine $(1.89 \mathrm{~mL}, 13.6 \mathrm{mmol}, 1.0$ equiv) was added dropwise, with release of gas. After $2 \mathrm{~h}$, the mixture was diluted with EtOAc $(40 \mathrm{~mL})$ and washed with $2 \mathrm{M} \mathrm{HCl}(50 \mathrm{~mL})$ and $\mathrm{NaCl}$ (saturated solution, $50 \mathrm{~mL}$ ). The organic layer was dried over $\mathrm{MgSO}_{4}$, filtered and concentrated in vacuo. Purification by column chromatography $\left(\mathrm{SiO}_{2}, \mathrm{DCM}\right.$ to DCM/AcOH 98/2) afforded 3-(benzyloxymethyl)- $N$-tosylpent-4-enamide (11) (4.58 g, $12.6 \mathrm{mmol}, 80 \%$ ) as a yellow solid.

$\mathrm{R}_{\mathrm{f}} 0.22$ (PET/EtOAc 4/1); ${ }^{1} \mathrm{H}$ NMR (400 MHz, $\mathrm{CDCl}_{3}$ ) $\delta 9.41$ (br s, $\left.1 \mathrm{H}, N H\right), 7.93(\mathrm{~m}, 2 \mathrm{H}$, tosyl $\mathrm{CH}), 7.44-7.23\left(\mathrm{~m}, 7 \mathrm{H}\right.$, tosyl $\mathrm{CH}$ and $\left.\mathrm{OCH}_{2} P h\right), 5.66(\mathrm{ddd}, 1 \mathrm{H}, J=17.7,10.1,7.7 \mathrm{~Hz}$, $\left.\mathrm{CHCH}=\mathrm{CH}_{2}\right), 5.11-4.94\left(\mathrm{~m}, 2 \mathrm{H}, \mathrm{CHCH}=\mathrm{CH}_{2}\right), 4.48\left(\mathrm{~s}, 2 \mathrm{H}, \mathrm{OCH}_{2} \mathrm{Ph}\right), 3.47(\mathrm{dd}, 1 \mathrm{H}, J=$ 9.4, $\left.5.1 \mathrm{~Hz}, \mathrm{CH}_{2} \mathrm{OCH}_{2} \mathrm{Ph}\right), 3.34\left(\mathrm{dd}, 1 \mathrm{H}, J=9.2,7.4 \mathrm{~Hz}, \mathrm{CH}_{2} \mathrm{OCH}_{2} \mathrm{Ph}\right), 2.83(\mathrm{~m}, 1 \mathrm{H}$, $\left.\mathrm{CHCH}=\mathrm{CH}_{2}\right), 2.54\left(\mathrm{dd}, 1 \mathrm{H}, J=15.2,6.3 \mathrm{~Hz}, \mathrm{COCH}_{2}\right), 2.43\left(\mathrm{~s}, 3 \mathrm{H}\right.$, tosyl $\left.\mathrm{CH}_{3}\right), 2.35(\mathrm{dd}, 1$ $\left.\mathrm{H}, J=15.2,7.0 \mathrm{~Hz}, \mathrm{COCH}_{2}\right) ;{ }^{13} \mathrm{C} \mathrm{NMR}\left(101 \mathrm{MHz}, \mathrm{CDCl}_{3}\right) \delta 169.9,144.8,137.6,136.8$, $135.6,129.4,128.4,128.2,127.7,127.7,116.7,73.1,72.4,39.7,38.9,21.6$; IR $3249(w)$,

[31] S. Couty, C. Meyer, J. Cossy, Tetrahedron 2009, 65, 1809. 
$3174(\mathrm{w}), 2864(\mathrm{w}), 2361(\mathrm{w}), 2256(\mathrm{w}), 1718(\mathrm{w}), 1643(\mathrm{w}), 1598(\mathrm{w}), 1493(\mathrm{w}), 1438(\mathrm{w})$, 1344 (w), 1309 (w), 1293 (w), 1241 (w), 1210 (w), 1163 (w), 1086 (m), 1026 (w), 996 (w), 908 (s), $856(\mathrm{w}), 816(\mathrm{w}), 729$ (s), $702(\mathrm{~m}), 666(\mathrm{~m})$; Melting point: $73.8-77.4^{\circ} \mathrm{C}$; HRMS (ESI) calcd for $\mathrm{C}_{20} \mathrm{H}_{24} \mathrm{NO}_{4}{ }^{+}\left(\mathrm{M}+\mathrm{H}^{+}\right) 374.1426$; found 374.1437.

3-(Benzyloxymethyl)- $N$-tosylpent-4-enamide (11) (2.2 g, $5.9 \mathrm{mmol}, 1.0$ equiv), TIPS-EBX (2a) (3.03 g, $7.07 \mathrm{mmol}, 1.2$ equiv), $\mathrm{PdCl}_{2}$ (52 mg, $0.29 \mathrm{mmol}, 0.05$ equiv) and $\mathrm{LiCl}$ ( $899 \mathrm{mg}$, $20.1 \mathrm{mmol}, 3.6$ equiv) were dissolved in $\mathrm{EtOH}(70 \mathrm{~mL})$ and the mixture was stirred at room temperature for $2 \mathrm{~h}$. EtOH was then evaporated and the residue was diluted with $\mathrm{Et}_{2} \mathrm{O}(70$ $\mathrm{mL}$ ) and washed with $\mathrm{Na}_{2} \mathrm{CO}_{3}$ (70 mL, saturated solution). The aqueous layer was extracted with $\mathrm{Et}_{2} \mathrm{O}(5 \times 70 \mathrm{~mL})$ and the combined organic layers were dried over $\mathrm{MgSO}_{4}$, filtered and concentrated in vacuo. Column chromatography $\left(\mathrm{SiO}_{2}\right.$, PET/EtOAc $\left.90 / 10\right)$ afforded 4(benzyloxymethyl)-1-tosyl-5-(3-(triisopropylsilyl)prop-2-ynyl)pyrrolidin-2-one (12) (2.36 g. $4.26 \mathrm{mmol}, 72 \%$ yield, mixture of inseparable diastereoisomers, $\mathrm{dr}$ 83:17) as a yellow oil.

$\mathrm{R}_{\mathrm{f}} 0.80(\mathrm{Pet} / \mathrm{EtOAc}=4 / 1) ;{ }^{1} \mathrm{H} \mathrm{NMR}\left(400 \mathrm{MHz}, \mathrm{CDCl}_{3}\right.$, signals for the minor diastereoisomer are reported in italics) $\delta 8.01(\mathrm{~m}, 2 \mathrm{H}$, tosyl $\mathrm{CH}), 7.95(\mathrm{~d}, 2 \mathrm{H}$, tosyl $\mathrm{CH}), 7.44-7.23(\mathrm{~m}, 7 \mathrm{H}$, tosyl $\mathrm{CH}$ and $\mathrm{OCH}_{2} P h$, both diastereisomers), $4.57(\mathrm{~m}, 1 \mathrm{H}, C H \mathrm{~N}), 4.55(\mathrm{~d}, 1 \mathrm{H}, J=11.9 \mathrm{~Hz}$, $\left.\mathrm{OCH}_{2} \mathrm{Ph}\right), 4.49$ (d, $\left.1 \mathrm{H}, J=11.8 \mathrm{~Hz}, \mathrm{OCH}_{2} \mathrm{Ph}\right), 4.44\left(\mathrm{~d}, 1 \mathrm{H}, J=12.2 \mathrm{~Hz}, \mathrm{OCH}_{2} \mathrm{Ph}\right), 4.40$ (d, $\left.1 \mathrm{H}, J=12.2 \mathrm{~Hz}, \mathrm{OCH}_{2} \mathrm{Ph}\right) .4 .38(\mathrm{ddd}, 1 \mathrm{H}, J=6.4,3.0,1.2 \mathrm{~Hz}, C H \mathrm{~N}), 3.88(\mathrm{t}, 1 \mathrm{H}, J=9.6$ $\left.\mathrm{Hz}, \mathrm{CH}_{2} \mathrm{O}\right), 3.66\left(\mathrm{dd}, 1 \mathrm{H}, J=9.5,5.5 \mathrm{~Hz}, \mathrm{CH}_{2} \mathrm{O}\right), 3.40\left(\mathrm{dd}, 1 \mathrm{H}, J=9.2,5.5 \mathrm{~Hz}, \mathrm{CH}_{2} \mathrm{O}\right)$, $3.33\left(\mathrm{dd}, 1 \mathrm{H}, J=9.1,6.8 \mathrm{~Hz}, \mathrm{CH}_{2} \mathrm{O}\right), 3.09$ (dd, $\left.J=18.0,4.7 \mathrm{~Hz}, \mathrm{COCH}_{2} \mathrm{CH}_{\text {or }} \mathrm{CH}_{2} \mathrm{C} \equiv \mathrm{C}\right)$, $2.98\left(\mathrm{dd}, J=17.2,6.6 \mathrm{~Hz}, \mathrm{COCH}_{2} \mathrm{CH}\right.$ or $\left.\mathrm{CH}_{2} \mathrm{C} \equiv \mathrm{C}\right), 2.90\left(\mathrm{dd}, J=18.0,9.5 \mathrm{~Hz}, \mathrm{COCH}_{2} \mathrm{CH}\right.$ or $\left.\mathrm{CH}_{2} \mathrm{C} \equiv \mathrm{C}\right), 2.83\left(\mathrm{dd}, \mathrm{J}=17.2,3.2 \mathrm{~Hz}, \mathrm{COCH}_{2} \mathrm{CH}\right.$ or $\left.\mathrm{CH}_{2} \mathrm{C} \equiv \mathrm{C}\right), 2.78-2.55\left(\mathrm{~m}, \mathrm{COCH}_{2} \mathrm{CH}\right.$ (major diastereoisomer) and $\mathrm{CH}_{2} \mathrm{C} \equiv \mathrm{C}, \mathrm{COCH}_{2} \mathrm{CH}$ (minor diastereoisomer)), 2.47-2.32 (m, $\mathrm{COCH}_{2}$ (minor diastereoisomer)), $2.43\left(\mathrm{~s}, 3 \mathrm{H}\right.$, tosyl $\left.\mathrm{CH}_{3}\right), 2.41\left(\mathrm{~s}, 3 \mathrm{H}\right.$, tosyl $\left.\mathrm{CH}_{3}\right), 2.20$ (dd, $\left.1 \mathrm{H}, J=17.9,1.9 \mathrm{~Hz}, \mathrm{COCH}_{2}\right), 1.07-0.95$ (m, $\left.21 \mathrm{H}, \mathrm{TIPS}\right), 0.96-0.87$ (m, $\left.21 \mathrm{H}, \mathrm{TIPS}\right) ;{ }^{13} \mathrm{C}$ NMR (101 MHz, $\left.\mathrm{CDCl}_{3}\right) \delta 172.7,144.8,137.5,135.5,129.4,129.4,128.5,128.5,128.5$, $128.4,128.0,127.8,127.8,127.6,103.4,102.6,84.5,73.4,73.2,71.7,68.2,61.1,59.1,36.6$, 36.4, 34.8, 34.3, 26.7, 21.6, 21.2, 18.5, 18.4, 11.1; ${ }^{[32]}$ IR 3033 (w), 2944 (w), 2891 (w), 2865 (w), 2362 (w), $2338(\mathrm{w}), 2257$ (w), $2174(\mathrm{w}), 1737(\mathrm{w}), 1599(\mathrm{w}), 1494(\mathrm{w}), 1462(\mathrm{w}), 1430$ (w), 1413 (w), $1401(\mathrm{w}), 1363(\mathrm{w}), 1312(\mathrm{w}), 1290(\mathrm{w}), 1242$ (w), $1191(\mathrm{w}), 1170(\mathrm{~m}), 1113$ (w), $1091(\mathrm{w}), 1022(\mathrm{w}), 997(\mathrm{w}), 957(\mathrm{w}), 908(\mathrm{~s}), 885(\mathrm{w}), 814(\mathrm{w}), 730$ (s), 703 (m), 678 $(\mathrm{m}), 652(\mathrm{~m}), 624(\mathrm{w})$; HRMS (ESI) calcd for $\mathrm{C}_{31} \mathrm{H}_{44} \mathrm{NO}_{4} \mathrm{SSi}^{+}\left(\mathrm{M}+\mathrm{H}^{+}\right)$554.2761; found 554.2773 .

\section{4-(Benzyloxymethyl)-5-(prop-2-ynyl)pyrrolidin-2-one (13)}

[32] Seven ${ }^{13} \mathrm{C}$ signals mostly from the minor diastereoisomer could not be resolved. 


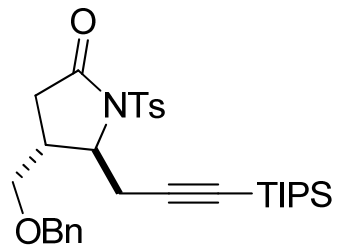

12

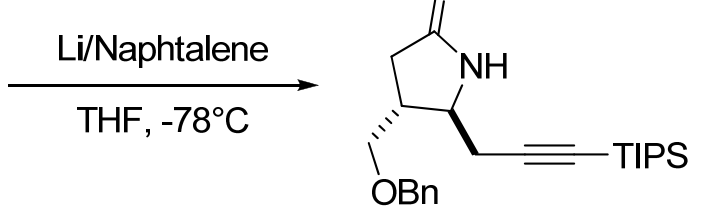

62

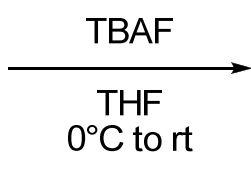

$\mathrm{OBn}$

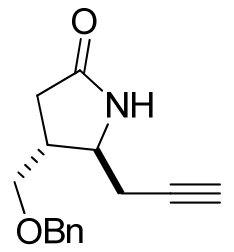

13

Following a slightly modified version of a reported procedure ${ }^{[30]}$ naphthalene $(1.79 \mathrm{~g}, 14.0$ $\mathrm{mmol}$ ) was dissolved in previously degassed THF (28 mL). Lithium (98 $\mathrm{mg}, 14 \mathrm{mmol})$ was added and the mixture was sonicated for $30 \mathrm{~min}$ and then stirred at room temperature for $2 \mathrm{~h}$ in order to obtain a $0.5 \mathrm{M}$ dark green Li-naphthalenide solution. $N$-tosyl lactam 12 (2.36 g, $4.26 \mathrm{mmol})$ was dissolved in THF $(7.5 \mathrm{~mL})$ and the resulting solution was cooled to $-78^{\circ} \mathrm{C}$. The Li-naphthalenide was then added dropwise until the reaction mixture stayed permanently dark green (ca $25 \mathrm{~mL}$, ca 3.0 equiv). The mixture was stirred at $-78^{\circ} \mathrm{C}$ for $30 \mathrm{~min}$ and at room temperature for $30 \mathrm{~min}$, before quenching with $1 \mathrm{M} \mathrm{NaHCO}_{3}$ (ca $30 \mathrm{~mL}$ ). The aqueous layer was extracted with EtOAc $(3 \times 30 \mathrm{~mL})$. The combined organic layers were dried over $\mathrm{MgSO}_{4}$, filtered and concentrated in vacuo. Purification by column chromatography $\left(\mathrm{SiO}_{2}\right.$, PET/EtOAc 80/20 to 50/50) gave 4-(benzyloxymethyl)-5-(3-(triisopropylsilyl)prop-2ynyl)pyrrolidin-2-one (62) (1.31 g, $3.27 \mathrm{mmol}, 77 \%$ yield) as a yellow oil.

Following a reported procedure, ${ }^{[19]}$ 4-(benzyloxymethyl)-5-(3-(triisopropylsilyl)prop-2ynyl)pyrrolidin-2-one (62) (1.30 g, $3.27 \mathrm{mmol}, 1.0$ equiv) was dissolved in THF (15 mL) and the resulting solution was cooled to $0^{\circ} \mathrm{C}$. TBAF $(1.0 \mathrm{M}$ in THF) $(6.5 \mathrm{~mL}, 6.5 \mathrm{mmol}, 2.0$ equiv) was added dropwise and the mixture was stirred at $0^{\circ} \mathrm{C}$ for two hours and then allowed to warm to room temperature overnight. $1 \mathrm{M} \mathrm{NaHCO}_{3}$ was then added (ca $20 \mathrm{~mL}$ ). The aqueous layer was extracted with EtOAc $(6 \times 20 \mathrm{~mL})$. The combined organic layers were dried over $\mathrm{MgSO}_{4}$, filtered and concentrated in vacuo. Purification by column chromatography ( $\mathrm{SiO}_{2}, \mathrm{DCM}$ to DCM/MeOH 95/5) afforded 4-(benzyloxymethyl)-5-(prop-2ynyl)pyrrolidin-2-one (13) (778 mg, $3.20 \mathrm{mmol}$, 98\% yield, mixture of inseparable diastereoisomers, dr 88:12) as an off-white solid.

$\mathrm{R}_{\mathrm{f}} \quad 0.36(\mathrm{PET} / \mathrm{EtOAc}=1 / 1) ;{ }^{1} \mathrm{H}$ NMR $\left(400 \mathrm{MHz}, \mathrm{CDCl}_{3}\right.$, signals for the minor diastereoisomer are reported in italics) $\delta 7.48-7.23(\mathrm{~m}, 5 \mathrm{H}, \mathrm{Ph}$, both diastereoisomers), 6.79 (br s, $1 \mathrm{H}$, both diastereoisomers), $4.51\left(\mathrm{~s}, 2 \mathrm{H}, \mathrm{OCH}_{2} \mathrm{Ph}\right), 4.49\left(\mathrm{~s}, 2 \mathrm{H}, \mathrm{OCH}_{2} \mathrm{Ph}\right), 3.85$ (td, $1 \mathrm{H}, J=7.6,5.1 \mathrm{~Hz}, C H \mathrm{~N}), 3.64(\mathrm{~m}, 1 \mathrm{H}, C H \mathrm{~N}), 3.58-3.52\left(\mathrm{~m}, 2 \mathrm{H}, \mathrm{CH}_{2} \mathrm{O}\right), 3.50-3.43(\mathrm{~m}, 2$ $\left.\mathrm{H}, \mathrm{CH}_{2} \mathrm{O}\right), 2.87\left(\mathrm{~m}, 1 \mathrm{H}, \mathrm{CHCH}_{2} \mathrm{O}\right), 2.60-2.41\left(\mathrm{~m}, \mathrm{COCH}_{2} \mathrm{CH}\right.$ and $\mathrm{CH}_{2} \mathrm{C} \equiv \mathrm{CH}$, both diastereoisomers), 2.41-2.22 (m, $\mathrm{COCH}_{2} \mathrm{CH}$ and $\mathrm{CH}_{2} \mathrm{C} \equiv \mathrm{CH}$, both diastereoisomers), 2.17 (dd, $\left.1 \mathrm{H}, J=16.4,5.4 \mathrm{~Hz}, \mathrm{COCH}_{2}\right), 2.04-2.00$ (m, $\mathrm{C} \equiv \mathrm{CH}$, both diastereoisomers); ${ }^{13} \mathrm{C} \mathrm{NMR}$ $\left(101 \mathrm{MHz} \mathrm{CDCl}_{3}\right) \delta 176.8,176.8,137.8,137.6,128.4,128.4,127.8,127.7,127.6,127.5$, $80.6,79.9,77.2,73.2,73.1,71.2,70.9,68.6,55.9,54.4,39.5,37.3,33.4,32.8,25.8,21.2$; IR 3288 (w), 2788 (w), $2004(w), 2003(w), 1964(w), 1963(w), 1818(w), 1794(w), 1694(\mathrm{~s})$, 1693 (s), $1581(\mathrm{w}), 1556(\mathrm{w}), 1555(\mathrm{w}), 1533$ (w), $1521(\mathrm{w}), 1520(\mathrm{w}), 1501(\mathrm{w}), 1483(\mathrm{w})$, 1448 (w), 1423 (w), 1392 (w), 1328 (w), 1299 (w), 1270 (w), $1210(\mathrm{w}), 1136(\mathrm{w}), 1099(\mathrm{w})$, 1073 (w), 1048 (w), 1033 (w), 1007 (w), 982 (w), 909 (w), 853 (w), 786 (m), 735 (s), 697 $(\mathrm{m}), 666(\mathrm{w}), 665(\mathrm{w}), 648(\mathrm{~m}), 627(\mathrm{~m})$; Melting point: $50.2-53.5^{\circ} \mathrm{C}$; HRMS (ESI) calcd for $\mathrm{C}_{15} \mathrm{H}_{18} \mathrm{NO}_{2}{ }^{+}\left(\mathrm{M}+\mathrm{H}^{+}\right)$244.1332; found 244.1343. 
7,7a-Dihydro-1 $H$-pyrrolizin-3(2H)-one (9a).

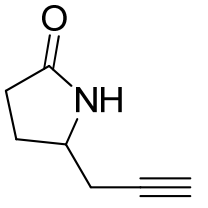

$8 a$

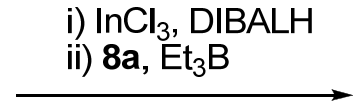

iii) $\mathrm{I}_{2}$

THF,$-78^{\circ} \mathrm{C}$

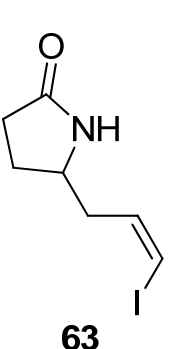

63

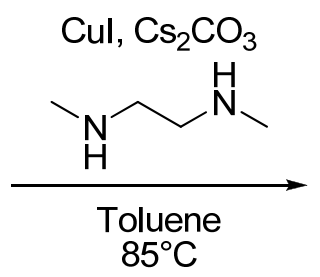

$9 \mathbf{a}$

Following a slightly modified version of a reported procedure, ${ }^{[33]} \mathrm{InCl}_{3}(96 \mathrm{mg}, 0.45 \mathrm{mmol}$, 1.5 equiv) was introduced into a Schlenk flask and heated with a heat gun $\left(150^{\circ} \mathrm{C}\right)$ under vacuum for $2 \mathrm{~min}$. After being allowed to cool to room temperature, THF $(1.3 \mathrm{~mL})$ was added under Ar. The mixture was stirred at room temperature for $10 \mathrm{~min}$ and cooled to $-78^{\circ} \mathrm{C}$ to get a whitish suspension. DIBALH ( $1.0 \mathrm{M}$ in hexane) $(0.44 \mathrm{~mL}, 0.44 \mathrm{mmol}, 1.5$ equiv) was added dropwise and the mixture was stirred at $-78^{\circ} \mathrm{C}$ for $40 \mathrm{~min}$. 5-(Prop-2-ynyl)pyrrolidin-2one $(\mathbf{8 a})\left(37 \mathrm{mg}, 0.30 \mathrm{mmol}, 1.0\right.$ equiv) was then added, followed by $\mathrm{Et}_{3} \mathrm{~B}(1.0 \mathrm{M}$ in THF, $0.12 \mathrm{~mL}, 0.12 \mathrm{mmol}, 0.4$ equiv) and the mixture was stirred at $-78^{\circ} \mathrm{C}$ for $4 \mathrm{~h}$. A solution of iodine ( $457 \mathrm{mg}, 1.80 \mathrm{mmol}, 6.0$ equiv) in THF $(0.7 \mathrm{~mL})$ was then added. After $40 \mathrm{~min}$, the mixture was poured onto a saturated solution of $\mathrm{NaHCO}_{3}$ (ca $10 \mathrm{~mL}$ ). $\mathrm{Na}_{2} \mathrm{~S}_{2} \mathrm{O}_{3}$ was added under stirring until complete decoloration and the aqueous layer was extracted with EtOAc (5 x $10 \mathrm{~mL}$ ). The combined organic layers were dried over $\mathrm{MgSO}_{4}$, filtered and concentrated in vacuo. Purification on a short chromatography column $\left(\mathrm{SiO}_{2}, \mathrm{DCM}\right.$ to $\left.\mathrm{DCM} / \mathrm{MeOH} 95 / 5\right)$ afforded 5-(3-iodoallyl)pyrrolidin-2-one (63) (mixture of $Z$ and $E$ stereoisomers, $Z / E$ 15/1; $74.3 \mathrm{mg}, 0.296 \mathrm{mmol}, 99 \%$ yield) as a yellow oil.

${ }^{1} \mathrm{H}$ NMR (400 MHz, $\mathrm{CD}_{2} \mathrm{Cl}_{2}, Z$ diastereoisomer) $\delta 7.23$ (br s, $\left.1 \mathrm{H}, N H\right), 6.46$ (dt, $1 \mathrm{H}, J=7.5$, $1.0 \mathrm{~Hz}, \mathrm{CH}_{2} \mathrm{CH}=\mathrm{CHI}$ ), 6.26 (q, $1 \mathrm{H}, J=7.1 \mathrm{~Hz}, \mathrm{CH}_{2} \mathrm{CH}=\mathrm{CHI}$ ), 3.82 (quint, $1 \mathrm{H}, J=6.4 \mathrm{~Hz}$, $\mathrm{NCH}), 2.40\left(\mathrm{td}, 2 \mathrm{H}, \mathrm{J}=6.5,1.0 \mathrm{~Hz}, \mathrm{CH}_{2} \mathrm{CH}=\mathrm{CHI}\right), 2.37-2.19\left(\mathrm{~m}, 3 \mathrm{H}, \mathrm{COCH}_{2} \mathrm{CH}_{2}\right), 1.81$ (m, $1 \mathrm{H}, \mathrm{COCH}_{2} \mathrm{CH}_{2}$ ).

Following a reported procedure, ${ }^{[34]} \mathrm{CuI}\left(22 \mathrm{mg}, 0.11 \mathrm{mmol}, 0.4\right.$ equiv) and $\mathrm{Cs}_{2} \mathrm{CO}_{3}(113 \mathrm{mg}$, $0.346 \mathrm{mmol}, 1.20$ equiv) were introduced into a Schlenk flask. The latter was kept under high vacuum for $5 \mathrm{~min}$, before being refilled with Ar. Toluene $(1.8 \mathrm{~mL})$ was added, followed by $N, N$ '-dimethylethane-1,2-diamine $(25 \mu \mathrm{L}, 0.23 \mathrm{mmol}, 0.8$ equiv) and the allyl iodide 63 (73 $\mathrm{mg}, 0.29 \mathrm{mmol}, 1.0$ equiv). The mixture was stirred at $75^{\circ} \mathrm{C}$ until total consumption of the starting material was confirmed by TLC (ca $30 \mathrm{~h}$ ). The reaction mixture was then allowed to cool to room temperature, diluted with DCM $(5 \mathrm{~mL})$ and washed with water $(5 \mathrm{~mL})$. The aqueous layer was extracted with DCM $(4 \times 5 \mathrm{~mL})$ and the combined organic layers were dried over $\mathrm{MgSO}_{4}$, filtered and concentrated in vacuo. Purification by column chromatography $\left(\mathrm{SiO}_{2}, \mathrm{DCM}\right.$ to $\mathrm{DCM} / \mathrm{MeOH}$ 95/5) afforded 7,7a-dihydro- $1 \mathrm{H}$-pyrrolizin$3(2 \mathrm{H})$-one (9a) (27 mg, $0.22 \mathrm{mmol}, 76 \%$ yield) as an off-white solid.

[33] K. Takami, S. Mikami, H. Yorimitsu, H. Shinokubo, K. Oshima, J. Org. Chem. 2003, 68, 6627.

[34] L. L. W. Cheung, A. Yudin, Org. Lett. 2009, 11, 1281. 
$\mathrm{R}_{\mathrm{f}} 0.36$ (AcOEt); ${ }^{1} \mathrm{H}$ NMR (400 MHz, $\left.\mathrm{CD}_{2} \mathrm{Cl}_{2}\right) \delta 6.54(\mathrm{~m}, 1 \mathrm{H}, \mathrm{NCH}=\mathrm{CH}), 5.36(\mathrm{~m}, 1 \mathrm{H}$, $\mathrm{NCH}=\mathrm{CH}), 4.39(\mathrm{~m}, 1 \mathrm{H}, \mathrm{NCH}), 2.82-2.59\left(\mathrm{~m}, 2 \mathrm{H}, \mathrm{COCH}_{2} \mathrm{CH}_{2}\right.$ and $\left.\mathrm{CH}=\mathrm{CHCH}_{2}\right), 2.54-2.33$ $\left(\mathrm{m}, 3 \mathrm{H}, \mathrm{COCH}_{2} \mathrm{CH}_{2}\right.$ and $\left.\mathrm{CH}=\mathrm{CHCH}_{2}\right), 1.86\left(\mathrm{~m}, 1 \mathrm{H}, \mathrm{COCH}_{2} \mathrm{CH}_{2}\right) ;{ }^{13} \mathrm{C} \mathrm{NMR}(101 \mathrm{MHz}$, $\left.\mathrm{CD}_{2} \mathrm{Cl}_{2}\right) \delta 171.3,125.5,115.0,61.5,36.4,35.7,29.5$; IR $3431(\mathrm{~m}), 2956(\mathrm{w}), 2908(\mathrm{w}), 2849$ (w), 2360 (w), 2341 (w), 1672 (s), 1597 (m), 1446 (m), 1445 (m), 1415 (s), 1347 (w), 1336 (w), 1302 (w), $1281(\mathrm{w}), 1263$ (w), 1223 (w), $1197(\mathrm{w}), 1122$ (w), $1119(\mathrm{w}), 1053$ (w), 932 (w), $809(\mathrm{~m}), 730(\mathrm{~m}), 696(\mathrm{~m}), 672(\mathrm{~m}), 655(\mathrm{~m}), 645(\mathrm{~m}), 638(\mathrm{~m}), 617(\mathrm{w}), 605(\mathrm{w})$; Melting point: $61.0-65.0^{\circ} \mathrm{C}$; HRMS (ESI) calcd for $\mathrm{C}_{7} \mathrm{H}_{10} \mathrm{NO}^{+}\left(\mathrm{M}+\mathrm{H}^{+}\right)$124.0762; found 124.0767.

\section{7,7a-Dihydropyrrolo[1,2-c]oxazol-3(1H)-one (9b)}

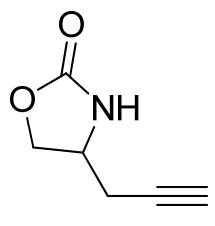
$8 b$

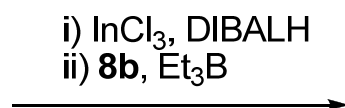

iii) $\mathrm{I}_{2}$

$\mathrm{THF},-78^{\circ} \mathrm{C}$

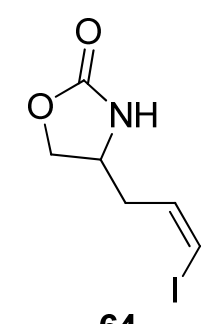

64

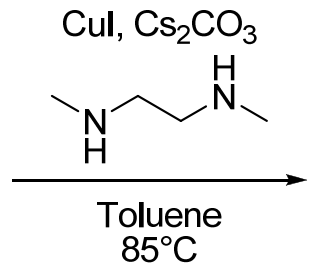

$9 b$

Following a slightly modified version of a reported procedure, ${ }^{[33]} \mathrm{InCl}_{3}(103 \mathrm{mg}, 0.465$ mmol, 1.55 equiv) was introduced into a Schlenk flask and heated with a heat gun $\left(150^{\circ} \mathrm{C}\right)$ under vacuum for $2 \mathrm{~min}$. After being allowed to cool to room temperature, THF (1.3 mL) was added under Ar. The mixture was stirred at room temperature for $10 \mathrm{~min}$ and cooled to $-78^{\circ} \mathrm{C}$ to get a whitish suspension. DIBALH (1.0 $\mathrm{M}$ in hexane) $(0.46 \mathrm{~mL}, 0.46 \mathrm{mmol}, 1.5$ equiv) was added dropwise and the mixture was stirred at $-78^{\circ} \mathrm{C}$ for $40 \mathrm{~min}$. 4-(Prop-2-ynyl)oxazolidin2-one (8b) (38 mg, $0.30 \mathrm{mmol}, 1.0$ equiv) was then added, followed by $\mathrm{Et}_{3} \mathrm{~B}$ (1.0 $\mathrm{M}$ in THF, $0.15 \mathrm{~mL}, 0.15 \mathrm{mmol}, 0.5$ equiv) and the mixture was stirred at $-78^{\circ} \mathrm{C}$ for $3 \mathrm{~h}$. A solution of iodine ( $460 \mathrm{mg}, 1.80 \mathrm{mmol}, 6.0$ equiv) in THF $(0.7 \mathrm{~mL})$ was then added. After $40 \mathrm{~min}$, the mixture was poured onto a saturated solution of $\mathrm{NaHCO}_{3}$ (ca $10 \mathrm{~mL}$ ). $\mathrm{Na}_{2} \mathrm{~S}_{2} \mathrm{O}_{3}$ was added under stirring until complete decoloration and the aqueous layer was extracted with EtOAc (5 x $10 \mathrm{~mL}$ ). The combined organic layers were dried over $\mathrm{MgSO}_{4}$, filtered and concentrated in vacuo. Purification by a short column chromatography $\left(\mathrm{SiO}_{2}, \mathrm{DCM}\right.$ to $\left.\mathrm{DCM} / \mathrm{MeOH} 95 / 5\right)$ afforded 4-(3-iodoallyl)oxazolidin-2-one (64) (mixture of $Z$ and $E$ stereoisomers, $Z / E$ 8/1; 62 $\mathrm{mg}, 0.25 \mathrm{mmol}, 82 \%$ yield) as a yellow oil.

${ }^{1} \mathrm{H}$ NMR (400 MHz, $\mathrm{CDCl}_{3}, Z$ diastereoisomer) $\delta 6.89$ (br s, $\left.1 \mathrm{H}, N H\right), 6.48$ (dd, $1 \mathrm{H}, J=7.5$, $\left.0.9 \mathrm{~Hz}, \mathrm{CH}_{2} \mathrm{CH}=\mathrm{CHI}\right), 6.21\left(\mathrm{~m}, 1 \mathrm{H}, \mathrm{CH}_{2} \mathrm{CH}=\mathrm{CHI}\right), 4.49$ (m, $\left.1 \mathrm{H}, \mathrm{OCH}_{2}\right), 4.12-4.00(\mathrm{~m}, 2 \mathrm{H}$, $\mathrm{OCH}_{2}$ and $\left.\mathrm{NCH}\right), 2.46\left(\mathrm{~m}, 2 \mathrm{H}, \mathrm{CH}_{2} \mathrm{CH}=\mathrm{CHI}\right)$.

Following a slightly modified version of a reported procedure ${ }^{[34]} \mathrm{CuI}(21 \mathrm{mg}, 0.11 \mathrm{mmol}$, 0.45 equiv) and $\mathrm{Cs}_{2} \mathrm{CO}_{3}$ (96 mg, $0.29 \mathrm{mmol}, 1.2$ equiv) were introduced into a Schlenk flask. The latter was kept under high vacuum for $5 \mathrm{~min}$, before being refilled with Ar. Toluene (1.6 $\mathrm{mL}$ ) was added, followed by $N, N$ '-dimethylethane-1,2-diamine $(24 \mu \mathrm{L}, 0.22 \mathrm{mmol}, 0.9$ equiv) and the allyl iodide 64 (62 $\mathrm{mg}, 0.24 \mathrm{mmol}, 1.0$ equiv; mixture of $Z / E$ diastereoisomers, $Z / E 8 / 1$ ). The mixture was stirred at $85^{\circ} \mathrm{C}$ until total consumption of the starting material was confirmed by TLC (ca $22 \mathrm{~h}$ ). It was then allowed to cool to room temperature, diluted with 
DCM ( $5 \mathrm{~mL})$ and washed with water $(5 \mathrm{~mL})$. The aqueous layer was extracted with DCM (4 x $5 \mathrm{~mL}$ ) and the combined organic layers were dried over $\mathrm{MgSO}_{4}$, filtered and concentrated in vacuo. Purification by column chromatography $\left(\mathrm{SiO}_{2}, \mathrm{DCM}\right.$ to $\left.\mathrm{DCM} / \mathrm{MeOH} 99 / 1\right)$ afforded 7,7a-dihydropyrrolo[1,2-c]oxazol-3(1H)-one (9b) $(27 \mathrm{mg}, 0.21 \mathrm{mmol}, 88 \%$ yield (quantitative with respect of the $Z$ diastereoisomer) as yellow oil.

$\mathrm{R}_{\mathrm{f}} 0.62(\mathrm{DCM} / \mathrm{MeOH} 40 / 1) ;{ }^{1} \mathrm{H} \mathrm{NMR}\left(400 \mathrm{MHz}, \mathrm{CDCl}_{3}\right) \delta 6.41(\mathrm{~m}, 1 \mathrm{H}, \mathrm{NCH}=\mathrm{CH}), 5.29$ $(\mathrm{m}, 1 \mathrm{H}, \mathrm{NCH}=\mathrm{CH}), 4.70\left(\mathrm{t}, 1 \mathrm{H}, J=8.5 \mathrm{~Hz}, \mathrm{OCH}_{2}\right), 4.61(\mathrm{ddd}, 1 \mathrm{H}, J=17.6,8.9,8.9 \mathrm{~Hz}, 1$ $\mathrm{H}, \mathrm{NCH}), 4.14$ (t, $\left.1 \mathrm{H}, J=8.4 \mathrm{~Hz}, \mathrm{OCH}_{2}\right), 2.75\left(\mathrm{~m}, 1 \mathrm{H}, \mathrm{CH}_{2} \mathrm{CH}=\mathrm{CH}\right), 2.53$ (ddt, $1 \mathrm{H}, J=$ 16.4, 9.2, $\left.2.5 \mathrm{~Hz}, \mathrm{CH}_{2} \mathrm{CH}=\mathrm{CH}\right) ;{ }^{13} \mathrm{C} \mathrm{NMR}\left(101 \mathrm{MHz}, \mathrm{CDCl}_{3}\right) \delta 157.4,128.1,113.5,71.4$, 57.9, 35.8; IR 3502 (w), 3100 (w), 2960 (w), 2911 (w), 2854 (w), 1747 (s), 1608 (w), 1541 (w), $1481(\mathrm{w}), 1449$ (w), 1379 (m), 1303 (m), 1260 (m), 1169 (w), 1080 (m), 1061 (s), 1003 (m), $926(\mathrm{w}), 840(\mathrm{w}), 771(\mathrm{~m}), 754(\mathrm{w}), 715(\mathrm{~m}), 667$ (w), $658(\mathrm{w})$; HRMS (ESI) calcd for $\mathrm{C}_{6} \mathrm{H}_{8} \mathrm{NO}_{2}^{+}\left(\mathrm{M}+\mathrm{H}^{+}\right)$126.0555; found 126.0559.

\section{6,7,8,8a-tetrahydroindolizin-5(1H)-one $(9 \mathrm{c})$}

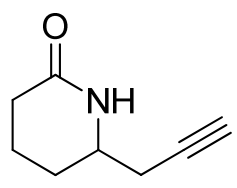

$8 c$

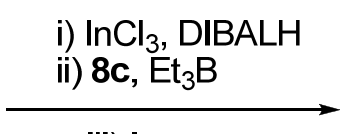

iii) $I_{2}$

THF, $-70^{\circ} \mathrm{C}$

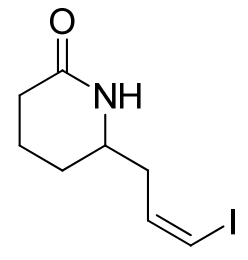

65

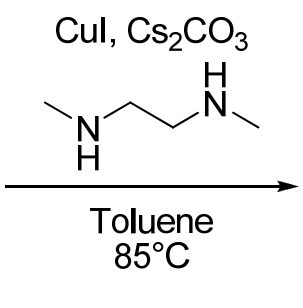

9c

Following a slightly modified version of a reported procedure, ${ }^{[33]} \mathrm{InCl}_{3}(113 \mathrm{mg}, 0.508$ mmol, 1.55 equiv) was introduced into a Schlenk flask and heated with a heat gun $\left(150^{\circ} \mathrm{C}\right)$ under vacuum for $2 \mathrm{~min}$. After being allowed to cool to room temperature, THF (1.35 mL) was added under Ar. The mixture was stirred at room temperature for $10 \mathrm{~min}$ and cooled to $65^{\circ} \mathrm{C}$ to get a whitish suspension. DIBALH $(1.0 \mathrm{M}$ in hexane) $(0.49 \mathrm{~mL}, 0.49 \mathrm{mmol}, 1.5$ equiv) was added dropwise and the mixture was stirred at $-65^{\circ} \mathrm{C}$ for $40 \mathrm{~min}$. 6-(Prop-2ynyl)piperidin-2-one (8c) (46 mg, $0.33 \mathrm{mmol}, 1.0$ equiv) was added, followed by $\mathrm{Et}_{3} \mathrm{~B}(1.0 \mathrm{M}$ in THF, $0.20 \mathrm{~mL}, 0.20 \mathrm{mmol}, 0.6$ equiv) and the mixture was stirred at $-70^{\circ} \mathrm{C}$ for $4 \mathrm{~h}$. A solution of iodine (500 mg, $1.97 \mathrm{mmol}, 6.0$ equiv) in THF $(0.8 \mathrm{~mL})$ was then added. After 40 min, the mixture was poured onto a saturated solution of $\mathrm{NaHCO}_{3}$ (ca $10 \mathrm{~mL}$ ). $\mathrm{Na}_{2} \mathrm{~S}_{2} \mathrm{O}_{3}$ was added under stirring until complete decoloration and the aqueous layer was extracted with EtOAc $(5 \times 10 \mathrm{~mL})$. The combined organic layers were dried over $\mathrm{MgSO}_{4}$, filtered and concentrated in vacuo. Purification by a short column chromatography $\left(\mathrm{SiO}_{2}, \mathrm{DCM}\right.$ to $\mathrm{DCM} / \mathrm{MeOH}$ 97/3) afforded (Z)-6-(3-iodoallyl)piperidin-2-one (65) (only $Z$ diastereoisomer; $88 \mathrm{mg}, 0.33 \mathrm{mmol}, 99 \%$ yield) as a yellowish solid.

${ }^{1} \mathrm{H} \mathrm{NMR}\left(400 \mathrm{MHz}, \mathrm{CDCl}_{3}\right) \delta 6.49\left(\mathrm{dt}, 1 \mathrm{H}, J=7.5,1.3 \mathrm{~Hz}, \mathrm{CH}_{2} \mathrm{CH}=\mathrm{CHI}\right), 6.20(\mathrm{q}, 1 \mathrm{H}, J=$ $7.2 \mathrm{~Hz}, \mathrm{CH}_{2} \mathrm{CH}=\mathrm{CHI}$ ), 5.67 (br s, $\left.1 \mathrm{H}, \mathrm{NH}\right), 3.56(\mathrm{~m}, 1 \mathrm{H}, \mathrm{NCH}), 2.48-2.19(\mathrm{~m}, 4 \mathrm{H}$, $\mathrm{CH}_{2} \mathrm{CH}=\mathrm{CHI}$ and $\left.\mathrm{COCH}_{2}\right), 1.93\left(\mathrm{~m}, 2 \mathrm{H}, \mathrm{COCH}_{2} \mathrm{CH}_{2} \mathrm{CH}_{2}\right), 1.70\left(\mathrm{~m}, 1 \mathrm{H}, \mathrm{COCH}_{2} \mathrm{CH}_{2} \mathrm{CH}_{2}\right)$, $1.47\left(\mathrm{~m}, 1 \mathrm{H}, \mathrm{COCH}_{2} \mathrm{CH}_{2} \mathrm{CH}_{2}\right)$. 
Following a slightly modified version of a reported procedure, ${ }^{[34]} \mathrm{CuI}(24 \mathrm{mg}, 0.13 \mathrm{mmol}$, 0.40 equiv) and $\mathrm{Cs}_{2} \mathrm{CO}_{3}$ (125 mg, $0.383 \mathrm{mmol}, 1.2$ equiv) were introduced into a Schlenk flask. The latter was kept under high vacuum for $5 \mathrm{~min}$, before being refilled with Ar. Toluene $(2.0 \mathrm{~mL})$ was added, followed by $N, N$ '-dimethylethane-1,2-diamine $(27 \mu \mathrm{L}, 0.25$ mmol, 0.8 equiv) and the allyl iodide $65(83 \mathrm{mg}, 0.31 \mathrm{mmol}, 1.0$ equiv). The mixture was stirred at $85^{\circ} \mathrm{C}$ until total consumption of the starting material was confirmed by TLC (ca 22 h). It was then allowed to cool to room temperature, diluted with DCM (7 mL) and washed with water $(7 \mathrm{~mL})$. The aqueous layer was extracted with DCM $(4 \times 7 \mathrm{~mL})$ and the combined organic layers were dried over $\mathrm{MgSO}_{4}$, filtered and concentrated in vacuo. Purification by column chromatography $\left(\mathrm{SiO}_{2}\right.$, EtOAc) afforded 6,7,8,8a-tetrahydroindolizin-5(1H)-one (9c) (28 mg, $0.20 \mathrm{mmol}, 66 \%$ yield) as pale yellow oil.

$\mathrm{R}_{\mathrm{f}} 0.43(\mathrm{DCM} / \mathrm{MeOH} 20 / 1) ;{ }^{1} \mathrm{H} \mathrm{NMR}\left(400 \mathrm{MHz}, \mathrm{CDCl}_{3}\right) \delta 6.91(\mathrm{~s}, 1 \mathrm{H}, \mathrm{NCH}=\mathrm{CH}), 5.24(\mathrm{~m}$, $1 \mathrm{H}, \mathrm{NCH}=\mathrm{CH}$ ), 3.91 (ddd, $1 \mathrm{H}, J=11.5,9.0,3.5 \mathrm{~Hz}, \mathrm{NCH}$ ), 2.66 (dddd, $1 \mathrm{H}, J=15.6,8.9$, 2.9, $\left.1.3 \mathrm{~Hz}, \mathrm{CH}_{2} \mathrm{CH}=\mathrm{CH}\right), 2.47-2.36\left(\mathrm{~m}, 2 \mathrm{H}, \mathrm{COCH}_{2}\right), 2.30$ (ddd, $1 \mathrm{H}, J=18.3,11.0,7.3$ $\left.\mathrm{Hz}, \mathrm{CH}_{2} \mathrm{CH}=\mathrm{CH}\right), 2.13\left(\mathrm{~m}, 1 \mathrm{H}\right.$, piperidone $\left.\mathrm{CH}_{2}\right), 1.95\left(\mathrm{~m}, 1 \mathrm{H}\right.$, piperidone $\left.\mathrm{CH}_{2}\right), 1.70(\mathrm{~m}, 1$ $\mathrm{H}$, piperidone $\left.\mathrm{CH}_{2}\right), 1.52$ (ddd, $1 \mathrm{H}, J=24.4,12.8,3.7 \mathrm{~Hz}$, piperidone $\left.\mathrm{CH}_{2}\right) ;{ }^{13} \mathrm{C} \mathrm{NMR}(101$ $\left.\mathrm{MHz}, \mathrm{CDCl}_{3}\right) \delta 166.1,128.8,111.1,59.3,37.0,30.3,28.4,20.7 ;$ IR 3461 (w), 3285 (w), 3110 (w), 2948 (w), 2857 (w), 1626 (s), 1448 (s), 1409 (s), 1369 (w), 1347 (w), 1320 (w), 1299 (m), 1274 (w), 1273 (w), 1226 (m), 1205 (w), 1179 (w), 1136 (w), 1104 (w), 1087 (w), 1045 (w), $957(\mathrm{~m}), 919(\mathrm{w}), 902(\mathrm{w}), 847(\mathrm{w}), 813(\mathrm{w}), 722(\mathrm{~m}), 685(\mathrm{w}), 667(\mathrm{w}), 663(\mathrm{w}), 643$ (w), $622(\mathrm{w})$; HRMS (ESI) calcd for $\mathrm{C}_{8} \mathrm{H}_{12} \mathrm{NO}^{+}\left(\mathrm{M}+\mathrm{H}^{+}\right)$138.0919; found 138.0915.

\section{1-(Benzyloxymethyl)-7,7a-dihydro-1H-pyrrolizin-3(2H)-one (15).}

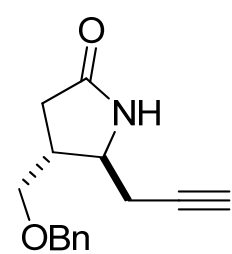
13

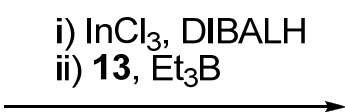

iii) $\mathrm{I}_{2}$

$\mathrm{THF},-50^{\circ} \mathrm{C}$
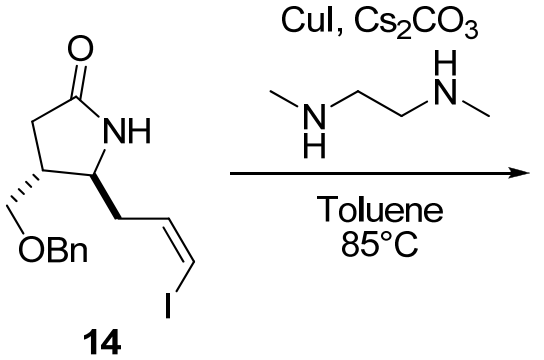

Following a slightly modified version of a reported procedure, ${ }^{[33]} \mathrm{InCl}_{3}(103 \mathrm{mg}, 0.465$ mmol, 1.55 equiv) was introduced into a Schlenk flask and heated with a heat gun $\left(150^{\circ} \mathrm{C}\right)$ under vacuum for $2 \mathrm{~min}$. After being allowed to cool to room temperature, THF (1.3 $\mathrm{mL})$ was added under Ar. The mixture was stirred at room temperature for $10 \mathrm{~min}$ and cooled to $-50^{\circ} \mathrm{C}$ to get a whitish suspension. DIBALH (1.0 $\mathrm{M}$ in hexane) $(0.46 \mathrm{~mL}, 0.46 \mathrm{mmol}, 1.5$ equiv) was added dropwise and the mixture was stirred at $-50^{\circ} \mathrm{C}$ for $40 \mathrm{~min}$. 4-(Benzyloxymethyl)-5(prop-2-ynyl)pyrrolidin-2-one (13) $(73 \mathrm{mg}, 0.30 \mathrm{mmol}, 1.0$ equiv) was then added, followed by $\mathrm{Et}_{3} \mathrm{~B}(1.0 \mathrm{M}$ in THF, $0.18 \mathrm{~mL}, 0.18 \mathrm{mmol}, 0.6$ equiv $)$ and the mixture was stirred at $-50^{\circ} \mathrm{C}$ for $2.5 \mathrm{~h}$. A solution of iodine (456 mg, $1.80 \mathrm{mmol}, 6.0$ equiv) in THF $(0.7 \mathrm{~mL})$ was then added. After $40 \mathrm{~min}$, the mixture was poured onto a saturated solution of $\mathrm{NaHCO}_{3}$ (ca 10 $\mathrm{mL}$ ). $\mathrm{Na}_{2} \mathrm{~S}_{2} \mathrm{O}_{3}$ was added under stirring until complete decoloration and the aqueous layer was extracted with EtOAc $(5 \times 10 \mathrm{~mL})$. The combined organic layers were dried over $\mathrm{MgSO}_{4}$, filtered and concentrated in vacuo. Purification by a short column chromatography 
( $\mathrm{SiO}_{2}, \mathrm{DCM}$ to DCM/MeOH 95/5) afforded 4-(benzyloxymethyl)-5-(3-iodoallyl)pyrrolidin2-one (14) (only $Z$ diastereoisomer; $106 \mathrm{mg}, 0.285 \mathrm{mmol}, 95 \%$ yield) as a yellowish oil.

${ }^{1} \mathrm{H}$ NMR $\left(400 \mathrm{MHz}, \mathrm{CDCl}_{3}\right) \delta 7.39-7.27(\mathrm{~m}, 5 \mathrm{H}, \mathrm{Ph}), 6.45(\mathrm{dt}, 1 \mathrm{H}, J=7.5,1.2 \mathrm{~Hz}$, $\mathrm{CH}_{2} \mathrm{CH}=\mathrm{CHI}$ ), 6.20 (q, $1 \mathrm{H}, J=7.2 \mathrm{~Hz}, \mathrm{CH}_{2} \mathrm{CH}=\mathrm{CHI}$ ), 5.67 (br s, $1 \mathrm{H}, \mathrm{NH}$ ), 4.53 (s, $2 \mathrm{H}$, $\left.\mathrm{OCH}_{2} \mathrm{Ph}\right), 3.67(\mathrm{~m}, 1 \mathrm{H}, \mathrm{NCH}), 3.47\left(\mathrm{~d}, 2 \mathrm{H}, \mathrm{J}=6.2 \mathrm{~Hz}, \mathrm{CH}_{2} \mathrm{O}\right), 2.60-2.28(\mathrm{~m}, 4 \mathrm{H}$, $\mathrm{COCH}_{2} \mathrm{CH}$ and $\left.\mathrm{CH}_{2} \mathrm{CH}=\mathrm{CHI}\right), 2.18\left(\mathrm{dd}, 1 \mathrm{H}, J=16.7,5.8 \mathrm{~Hz}, \mathrm{CH}_{2} \mathrm{CH}=\mathrm{CHI}\right)$.

Following a slightly modified version of a reported procedure, ${ }^{[34]} \mathrm{CuI}(21 \mathrm{mg}, 0.11 \mathrm{mmol}$, 0.40 equiv) and $\mathrm{Cs}_{2} \mathrm{CO}_{3}$ (111 mg, $0.342 \mathrm{mmol}, 1.2$ equiv) were introduced into a Schlenk flask. The latter was kept under high vacuum for $5 \mathrm{~min}$, before being refilled with Ar. Toluene $(1.8 \mathrm{~mL})$ was added, followed by $N, N$ '-dimethylethane-1,2-diamine $(25 \mu \mathrm{L}, 0.23$ mmol, 0.8 equiv) and the allyl iodide 14 (106 $\mathrm{mg}, 0.285 \mathrm{mmol}, 1.0$ equiv). The mixture was stirred at $75^{\circ} \mathrm{C}$ until total consumption of the starting material was confirmed by TLC (ca 40 h). It was then allowed to cool to room temperature, diluted with DCM (5 mL) and washed with water $(5 \mathrm{~mL})$. The aqueous layer was extracted with DCM $(4 \times 5 \mathrm{~mL})$ and the combined organic layers were dried over $\mathrm{MgSO}_{4}$, filtered and concentrated in vacuo. Purification by column chromatography ( $\mathrm{SiO}_{2}, \mathrm{DCM}$ to $\mathrm{DCM} / \mathrm{MeOH}$ 97/3) afforded 1-(benzyloxymethyl)7,7a-dihydro- $1 H$-pyrrolizin-3(2H)-one (15) (46 mg, $0.19 \mathrm{mmol}, 67 \%$ yield; 73\% yield based on starting material recovery; mixture of separable diastereoisomers, $\mathrm{dr} 86: 14$ ) as a pale yellow oil and starting material 14 (11.3 $\mathrm{mg}, 0.0304 \mathrm{mmol}, 11 \%)$.

\section{Major diastereoisomer:}

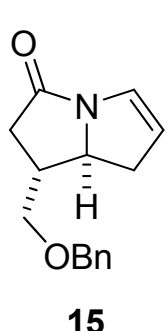

$\mathrm{R}_{\mathrm{f}} 0.50$ (EtOAc); ${ }^{1} \mathrm{H}$ NMR (400 MHz, $\left.\mathrm{CDCl}_{3}\right) \delta$ 7.42-7.21 (m, $\left.5 \mathrm{H}, \mathrm{Ph}\right), 6.52$ $(\mathrm{ddd}, 1 \mathrm{H}, J=4.3,2.7,1.7 \mathrm{~Hz}, \mathrm{NCH}=\mathrm{CH}), 5.32(\mathrm{dt}, 1 \mathrm{H}, J=4.6,2.6 \mathrm{~Hz}$, $\mathrm{NCH}=C H), 4.53\left(\mathrm{~d}, 1 \mathrm{H}, J=12.0 \mathrm{~Hz}, \mathrm{OCH}_{2} \mathrm{Ph}\right), 4.50(\mathrm{~d}, 1 \mathrm{H}, J=12.2 \mathrm{~Hz}$, $\left.\mathrm{OCH}_{2} \mathrm{Ph}\right), 4.17(\mathrm{~m}, 1 \mathrm{H}, \mathrm{NCH}), 3.59\left(\mathrm{~m}, 1 \mathrm{H}, \mathrm{CH}_{2} \mathrm{O}\right), 3.49\left(\mathrm{~m}, 1 \mathrm{H}, \mathrm{CH}_{2} \mathrm{O}\right), 2.65$ (dddd, $\left.1 \mathrm{H}, J=16.5,9.6,2.9,1.9 \mathrm{~Hz}, \mathrm{CH}_{2} \mathrm{CH}=\mathrm{CH}\right), 2.58-2.51\left(\mathrm{~m}, 3 \mathrm{H}, \mathrm{CHCH}_{2} \mathrm{O}\right.$ and $\left.\mathrm{COCH}_{2}\right), 2.44\left(\mathrm{ddt}, 1 \mathrm{H}, J=16.3,10.1,2.4 \mathrm{~Hz}, \mathrm{CH}_{2} \mathrm{CH}=\mathrm{CH}\right) ;{ }^{13} \mathrm{C} \mathrm{NMR}(101$ $\left.\mathrm{MHz}, \mathrm{CDCl}_{3}\right) \delta 170.4,137.9,128.3,127.6,127.3,125.6,115.6,73.1,70.8,64.8$, 44.1, 39.2, 35.3; IR 3110 (w), 2904 (w), 2880 (w), 2360 (s), 2340 (m), 1845 (m), $1811(\mathrm{~m})$, $1701(\mathrm{~m}), 1683(\mathrm{~s}), 1650(\mathrm{~m}), 1635(\mathrm{~m}), 1621(\mathrm{~m}), 1572(\mathrm{~m}), 1558(\mathrm{~m}), 1542$ (s), $1521(\mathrm{~s})$, 1488 (m), 1403 (s), 1329 (m), 1329 (m), 1301 (m), 1276 (m), 1142 (m), 1036 (s), 1007 (s), 981 (s), 932 (s), 901 (s), 865 (s), 853 (s), 766 (s), 721 (s), 693 (s), 650 (s), 643 (s), 625 (s); HRMS (ESI) calcd for $\mathrm{C}_{15} \mathrm{H}_{18} \mathrm{NO}_{2}^{+}\left(\mathrm{M}+\mathrm{H}^{+}\right)$244.1332; found 244.1329.

\section{Minor diastereoisomer:}

${ }^{1} \mathrm{H}$ NMR (400 MHz, $\left.\mathrm{CDCl}_{3}\right) \delta$ 7.45-7.24 (m, $\left.5 \mathrm{H}, \mathrm{Ph}\right), 6.56(\mathrm{~m}, 1 \mathrm{H}, \mathrm{NCH}=\mathrm{CH}), 5.35$ (m, 1 $\mathrm{H}, \mathrm{NCH}=C H), 4.61(\mathrm{td}, 1 \mathrm{H}, J=10.5,6.3 \mathrm{~Hz}, \mathrm{NCH}), 4.48\left(\mathrm{~s}, 2 \mathrm{H}, \mathrm{OCH}_{2} \mathrm{Ph}\right), 3.55(\mathrm{dd}, 1 \mathrm{H}, J$ $\left.=9.4,7.1 \mathrm{~Hz}, \mathrm{CH}_{2} \mathrm{O}\right), 3.41\left(\mathrm{dd}, 1 \mathrm{H}, \mathrm{J}=9.4,5.7 \mathrm{~Hz}, \mathrm{CH}_{2} \mathrm{O}\right), 2.81-2.65\left(\mathrm{~m}, 2 \mathrm{H}, \mathrm{COCH}_{2}\right.$ and $\left.\mathrm{CH}_{2} \mathrm{CH}=\mathrm{CH}\right), 2.59\left(\mathrm{~m}, 1 \mathrm{H}, \mathrm{CHCH}_{2} \mathrm{O}\right), 2.53-2.37\left(\mathrm{~m}, 2 \mathrm{H}, \mathrm{COCH}_{2}\right.$ and $\left.\mathrm{CH}_{2} \mathrm{CH}=\mathrm{CH}\right)$.

((1S,7aR)-hexahydro-1H-pyrrolizin-1-yl)methanol (16) (( \pm -Trachelanthamidine) 


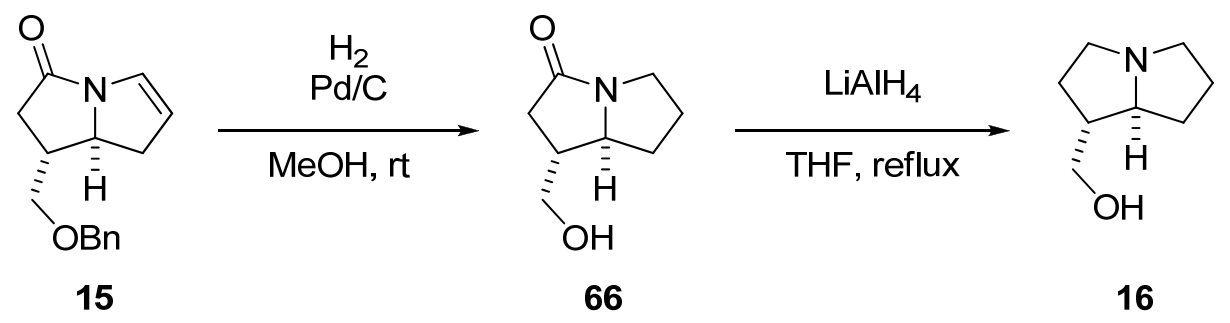

Enamide 15 (133 mg, $0.547 \mathrm{mmol})$ was dissolved in $\mathrm{MeOH}(10 \mathrm{~mL})$. The solution was flushed with $\mathrm{H}_{2}$ as $\mathrm{Pd} / \mathrm{C}$ was added portionwise until complete conversion was confirmed by TLC (ca $200 \mathrm{mg}$, over $36 \mathrm{~h}$ ). The mixture was then filtered through a celite plug, which was then washed with $\mathrm{MeOH}(8 \times 5 \mathrm{~mL})$ and DCM $(8 \times 5 \mathrm{~mL})$. The solvents were evaporated under reduced pressure to afford pure (1S,7aR)-1-(hydroxymethyl)tetrahydro- $1 H$-pyrrolizin$3(2 \mathrm{H})$-one (66) (85 mg, $0.55 \mathrm{mmol}$, quantitative) as an amorphous solid.

$\mathrm{R}_{\mathrm{f}} 0.23(\mathrm{DCM} / \mathrm{MeOH}=10 / 1) ;{ }^{1} \mathrm{H}$ NMR $\left(400 \mathrm{MHz}, \mathrm{CDCl}_{3}\right) \delta 3.78(\mathrm{dd}, 1 \mathrm{H}, J=10.5,5.5 \mathrm{~Hz}$, $\left.\mathrm{CH}_{2} \mathrm{OH}\right), 3.76-3.65\left(\mathrm{~m}, 2 \mathrm{H}, \mathrm{CH}_{2} \mathrm{OH}\right.$ and $\left.\mathrm{CH}_{2} \mathrm{~N}\right), 3.54(\mathrm{dt}, 1 \mathrm{H}, J=11.7,7.9 \mathrm{~Hz}, \mathrm{NCH}), 3.05$ $(\mathrm{m}, 1 \mathrm{H}), 2.62-2.45(\mathrm{~m}, 2 \mathrm{H}), 2.35(\mathrm{~m}, 1 \mathrm{H}), 2.21-1.93(\mathrm{~m}, 3 \mathrm{H}), 1.62(\mathrm{~m}, 1 \mathrm{H}, \mathrm{OH}), 1.43(\mathrm{~m}$, $1 \mathrm{H}) ;{ }^{13} \mathrm{C}$ NMR $\left(101 \mathrm{MHz} \mathrm{CDCl}_{3}\right) \delta 174.0,65.1,63.7,44.0,41.0,38.1,31.5,26.8$; IR 3399 (m), $2963(\mathrm{w}), 2921(\mathrm{w}), 2885(\mathrm{w}), 2361(\mathrm{w}), 1664(\mathrm{~s}), 1442(\mathrm{~m}), 1425(\mathrm{~m}), 1364(\mathrm{w}), 1334$ (w), $1310(\mathrm{w}), 1284(\mathrm{w}), 1238(\mathrm{w}), 1210(\mathrm{w}), 1168(\mathrm{w}), 1087(\mathrm{w}), 1039(\mathrm{~m}), 976(\mathrm{w}), 946$ (w), $913(\mathrm{w}), 890(\mathrm{w}), 874(\mathrm{w}), 835(\mathrm{w}), 816(\mathrm{w}), 797(\mathrm{w}), 760(\mathrm{w}), 735(\mathrm{w}), 695(\mathrm{w}), 666$ $(\mathrm{m}), 638(\mathrm{w}), 612(\mathrm{w})$; HRMS (ESI) calcd for $\mathrm{C}_{8} \mathrm{H}_{14} \mathrm{NO}_{2}{ }^{+}\left(\mathrm{M}+\mathrm{H}^{+}\right)$156.1019; found 156.1016.

Amide 66 (40.5 mg, $0.261 \mathrm{mmol}, 1.0$ equiv) was dissolved in THF (3.2 mL). $\mathrm{LiAlH}_{4}(40 \mathrm{mg}$, $1.0 \mathrm{mmol}, 4.0$ equiv) was added and the mixture was stirred under reflux until complete conversion was confirmed by TLC ( $\mathrm{ca} 18 \mathrm{~h}$ ). The reaction was then quenched by addition of water $(0.040 \mathrm{~mL}), \mathrm{NaOH} 15 \%(0.060 \mathrm{~mL})$ and water $(0.150 \mathrm{~mL})$. The mixture was stirred at room temperature for $1 \mathrm{~h}$ and filtered through a celite plug, which was then washed with EtOAc. The resulting solution was concentrated in vacuo. Purification by short column chromatography $\left(\mathrm{SiO}_{2}\right.$, ULTRA/DCM 1/1 to ULTRA; ULTRA: DCM/MeOH/( $\mathrm{NH}_{3} 25 \%$ in water) 75/25/5) afforded ( \pm )-Trachelanthamidine (16) (34.5 mg, $0.244 \mathrm{mmol}, 94 \%$ yield) as a pale yellow oil.

$\mathrm{R}_{\mathrm{f}} 0.27$ (ULTRA); ${ }^{1} \mathrm{H}$ NMR (400 MHz, $\left.\mathrm{CDCl}_{3}\right) \delta 4.56$ (s, $\left.1 \mathrm{H}, O H\right), 3.54$ (d, $2 \mathrm{H}, J=6.4 \mathrm{~Hz}$, $\mathrm{CH}_{2} \mathrm{OH}$ ), 3.18 (apparent q, $1 \mathrm{H}, J=6.5 \mathrm{~Hz}, \mathrm{CH}_{2} \mathrm{~N}$ ), 3.10 (ddd, $1 \mathrm{H}, J=10.0,6.8,3.2 \mathrm{~Hz}$, $\mathrm{CH}_{2} \mathrm{~N}$ ), $2.92(\mathrm{dt}, 1 \mathrm{H}, \mathrm{J}=10.7,6.4 \mathrm{~Hz}, \mathrm{NCH}), 2.61-2.44\left(\mathrm{~m}, 2 \mathrm{H}, \mathrm{CH}_{2} \mathrm{~N}\right), 2.03-1.45(\mathrm{~m}, 7 \mathrm{H})$; ${ }^{13} \mathrm{C}$ NMR $\left(101 \mathrm{MHz}, \mathrm{CDCl}_{3}\right) \delta$ 67.0, 64.2, 54.0, 53.8, 47.7, 31.2, 29.3, 24.9; IR $3368(\mathrm{~m})$, 2950 (m), 2869 (s), $2834(\mathrm{~m}), 2237(\mathrm{w}), 1699(\mathrm{w}), 1684(\mathrm{w}), 1673(\mathrm{w}), 1668(\mathrm{w}), 1662(\mathrm{w})$, $1653(\mathrm{w}), 1648(\mathrm{w}), 1637(\mathrm{w}), 1626(\mathrm{w}), 1559(\mathrm{w}), 1542(\mathrm{w}), 1520(\mathrm{w}), 1508(\mathrm{w}), 1497(\mathrm{w})$, 1488 (w), 1473 (w), 1457 (w), 1450 (w), 1419 (w), 1407 (w), 1397 (w), 1377 (w), 1355 (w), 1338 (w), 1317 (w), 1299 (w), 1289 (w), 1259 (w), 1190 (w), $1177(\mathrm{w}), 1142(\mathrm{w}), 1136(\mathrm{w})$, $1086(\mathrm{w}), 1061(\mathrm{~m}), 1041(\mathrm{~m}), 1034(\mathrm{~m}), 1009(\mathrm{w}), 922(\mathrm{w}), 906(\mathrm{w}), 878(\mathrm{w}), 860(\mathrm{w}), 855$ (w), $843(\mathrm{w}), 839(\mathrm{w}), 830(\mathrm{w}), 821(\mathrm{w}), 812(\mathrm{w}), 797(\mathrm{w}), 788(\mathrm{w}), 780(\mathrm{w}), 770(\mathrm{w}), 762$ (w), $730(\mathrm{~s}), 708(\mathrm{~m}), 683(\mathrm{~m}), 675(\mathrm{~m}), 660(\mathrm{~m}), 647(\mathrm{~m}), 640(\mathrm{~m}), 633(\mathrm{~s}), 608(\mathrm{~m})$; HRMS (ESI) calcd for $\mathrm{C}_{8} \mathrm{H}_{16} \mathrm{NO}^{+}[\mathrm{M}+\mathrm{H}]^{+}$142.1226; found 142.1224. 
Values in the literature: ${ }^{[35]}$

${ }^{1} \mathrm{H}$ NMR (270 MHz, $\mathrm{CDCl}_{3}$ ) d 4.25-4.05 (br s, $\left.1 \mathrm{H}\right), 3.59$ (d, $\left.2 \mathrm{H}, J=6.3 \mathrm{~Hz}\right), 3.22(\mathrm{dd}, 1 \mathrm{H}$, $J=13.2,6.3 \mathrm{~Hz}$ ), $3.13(\mathrm{ddd}, 1 \mathrm{H}, J=10.1,7.1,3.5 \mathrm{~Hz}), 2.95$ (dt, $1 \mathrm{H}, J=10.5,6.3 \mathrm{~Hz}$ ), 2.64-2.48 (m, $2 \mathrm{H}), 2.05-1.50(\mathrm{~m}, 7 \mathrm{H}) ;{ }^{13} \mathrm{C} \mathrm{NMR}\left(67.8 \mathrm{MHz}, \mathrm{CDCl}_{3}\right) \mathrm{d}$ 67.6, 64.9, 54.7, $54.4,48.3,31.9,29.9,25.6$.

After recalibration (reference signal for ${ }^{1} \mathrm{H}-\mathrm{NMR}$ : doublet at $3.59 \mathrm{ppm}$; reference peak for ${ }^{13} \mathrm{C}$ : singlet at $25.6 \mathrm{ppm}$ set as identical in the measured spectra) the values reported are in agreement with the literature ones:

${ }^{1} \mathrm{H}$ NMR (400 MHz, $\left.\mathrm{CDCl}_{3}\right) \delta 4.61(\mathrm{~s}, 1 \mathrm{H}), 3.59$ (d, $\left.2 \mathrm{H}, J=6.4 \mathrm{~Hz}\right), 3.23$ (apparent q, $1 \mathrm{H}$, $J=6.5 \mathrm{~Hz}$ ), 3.14 (ddd, $1 \mathrm{H}, J=10.0,6.8,3.2 \mathrm{~Hz}), 2.95(\mathrm{dt}, 1 \mathrm{H}, J=10.7,6.4 \mathrm{~Hz}), 2.67-2.48$ (m, $2 \mathrm{H}), 2.08-1.48(\mathrm{~m}, 7 \mathrm{H}) ;{ }^{13} \mathrm{C} \mathrm{NMR}\left(101 \mathrm{MHz}, \mathrm{CDCl}_{3}\right) \delta 67.7,64.9$, 54.7, 54.4, 48.4, 31.9, 30.0, 25.6.

\section{Mechanistic Investigations}

\section{${ }^{1}$ H-NMR experiments}

A) Tosyl amide 1a $(8.1 \mathrm{mg}, 0.032 \mathrm{mmol})$ was dissolved in $\mathrm{MeOH}-\mathrm{d}_{4}(0.8 \mathrm{~mL})$ in a NMR tube. ${ }^{1} \mathrm{H}-\mathrm{NMR}$ spectrum of this solution was acquired. $\mathrm{Li}_{2}\left[\mathrm{PdCl}_{4}\right] \cdot \mathrm{xH}_{2} \mathrm{O}$ (ca $9 \mathrm{mg}$, $0.03 \mathrm{mmol}, 1$ equiv) was dissolved in $\mathrm{MeOH}_{-} \mathrm{d}_{4}(0.8 \mathrm{~mL})$ in a NMR tube. ${ }^{1} \mathrm{H}-\mathrm{NMR}$ spectrum of this solution was acquired. Tosyl amide 1a $(8.1 \mathrm{mg}, 0.032 \mathrm{mmol}, 1.0$ equiv) was added and ${ }^{1} \mathrm{H}-\mathrm{NMR}$ spectra of the resulting mixture were acquired after 2 , 4, 6, 8, and $11 \mathrm{~min}$. After this time, TIPS-EBX (14 mg, $0.032 \mathrm{mmol})$ was added.

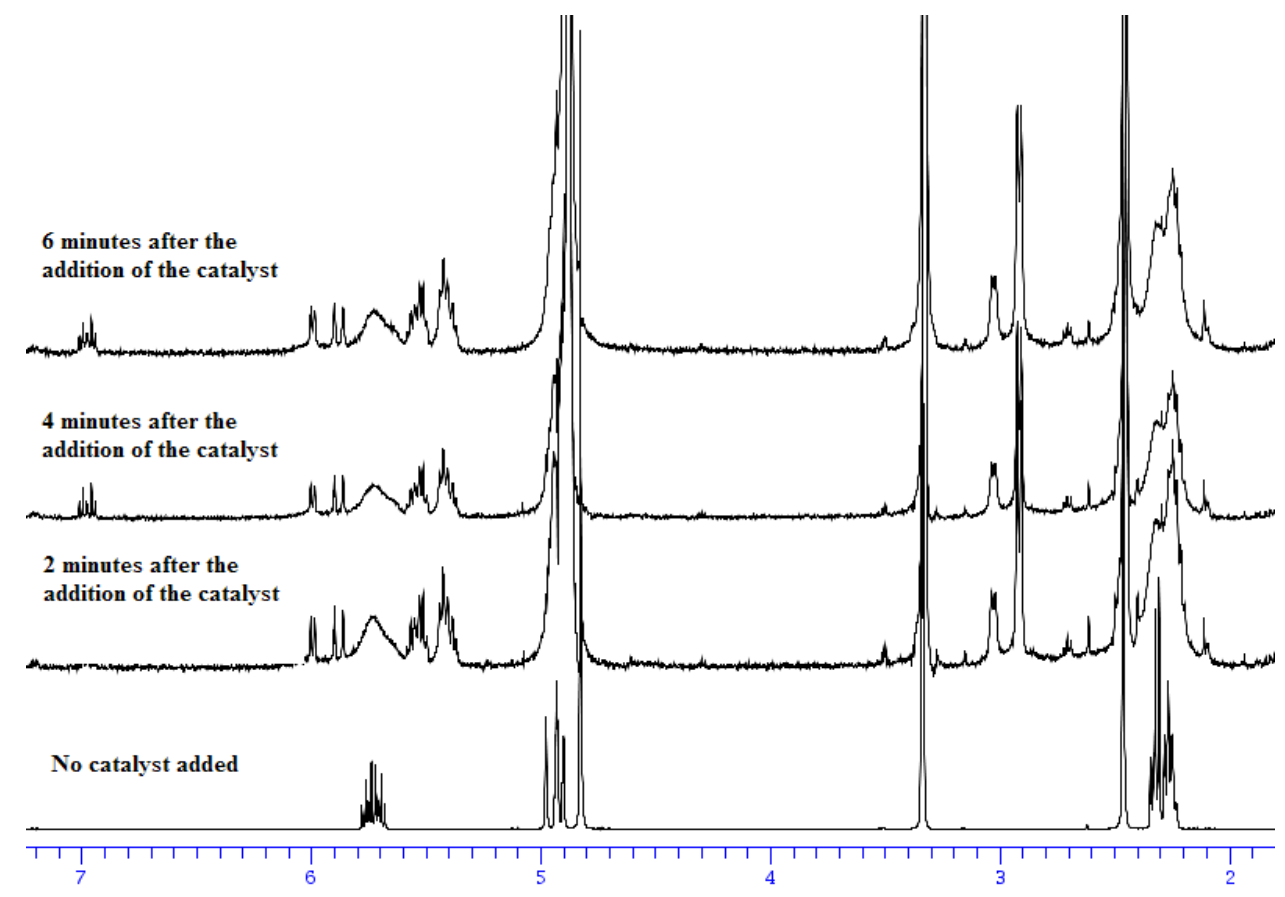

Figure S1. Addition of catalyst to $\mathbf{3 a}$ followed by ${ }^{1} \mathrm{H}$ NMR.

[35] H. Ishibashi, M. Sasaki, T. Taniguchi, Tetrahedron 2008, 64, 7771. 
B) TIPS-EBX (2a) $(14 \mathrm{mg}, 0.032 \mathrm{mmol})$ was dissolved in $\mathrm{MeOH}-\mathrm{d}_{4}(0.8 \mathrm{~mL})$ in a NMR tube. ${ }^{1} \mathrm{H}-\mathrm{NMR}$ spectrum of this solution was acquired. $\mathrm{Li}_{2}\left[\mathrm{PdCl}_{4}\right] \cdot \mathrm{xH}_{2} \mathrm{O}$ (ca $9 \mathrm{mg}$, $0.03 \mathrm{mmol}, 1$ equiv) was dissolved in $\mathrm{MeOH}-\mathrm{d}_{4}(0.8 \mathrm{~mL})$ in a NMR tube. ${ }^{1} \mathrm{H}-\mathrm{NMR}$ spectrum of this solution was acquired. TIPS-EBX (2a) (14 mg, $0.032 \mathrm{mmol}$ ) was added and ${ }^{1} \mathrm{H}-\mathrm{NMR}$ spectra of the resulting mixture were acquired after 2, 4, 6, 8, and $11 \mathrm{~min}$.

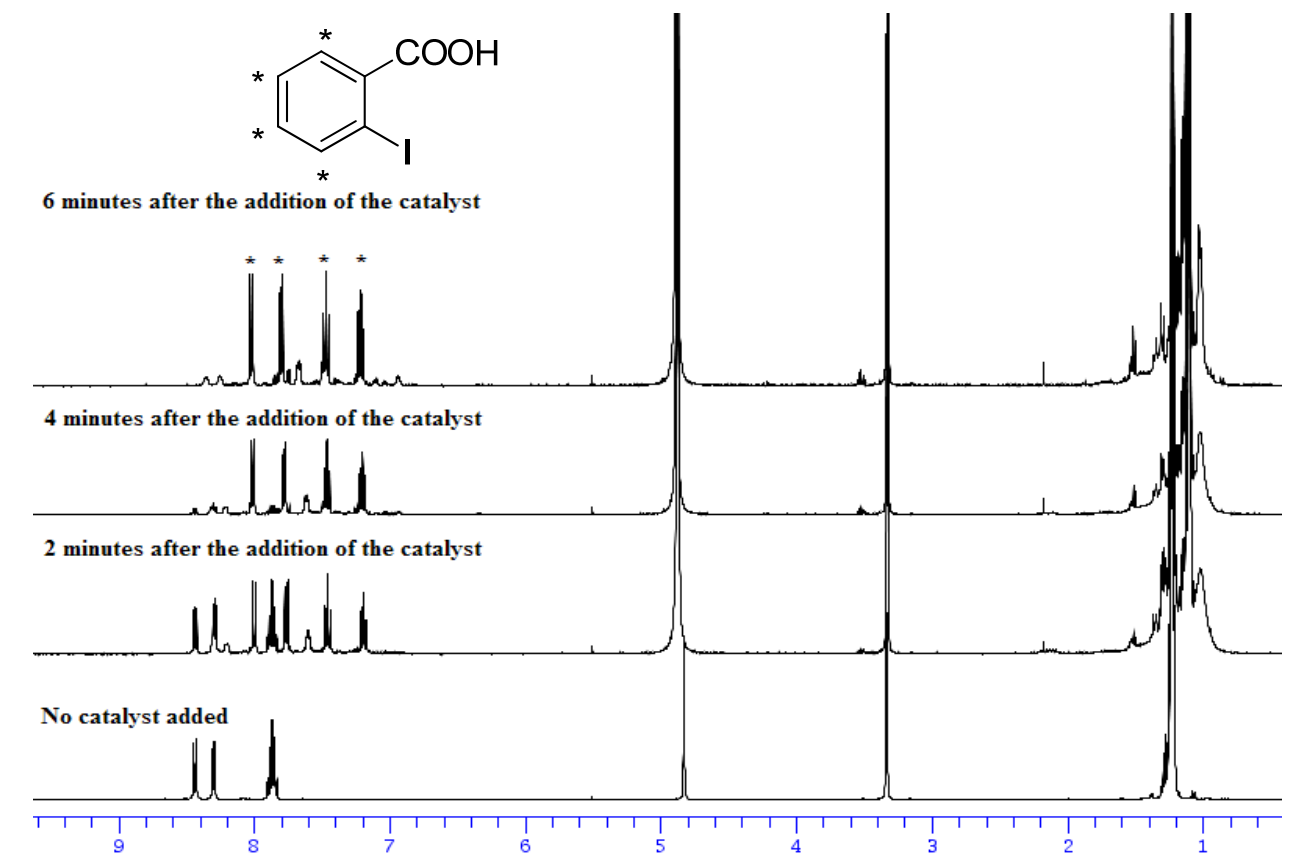

Figure S2. Addition of catalyst to TIPS-EBX (2a) followed by ${ }^{1} \mathrm{H}$ NMR. 


\section{Spectra of New Compounds}

1-(Phenylethynyl)-1,2-benziodoxol-3(1H)-one (Ph-EBX, 2b)

solvent: $\mathrm{CDCI}$

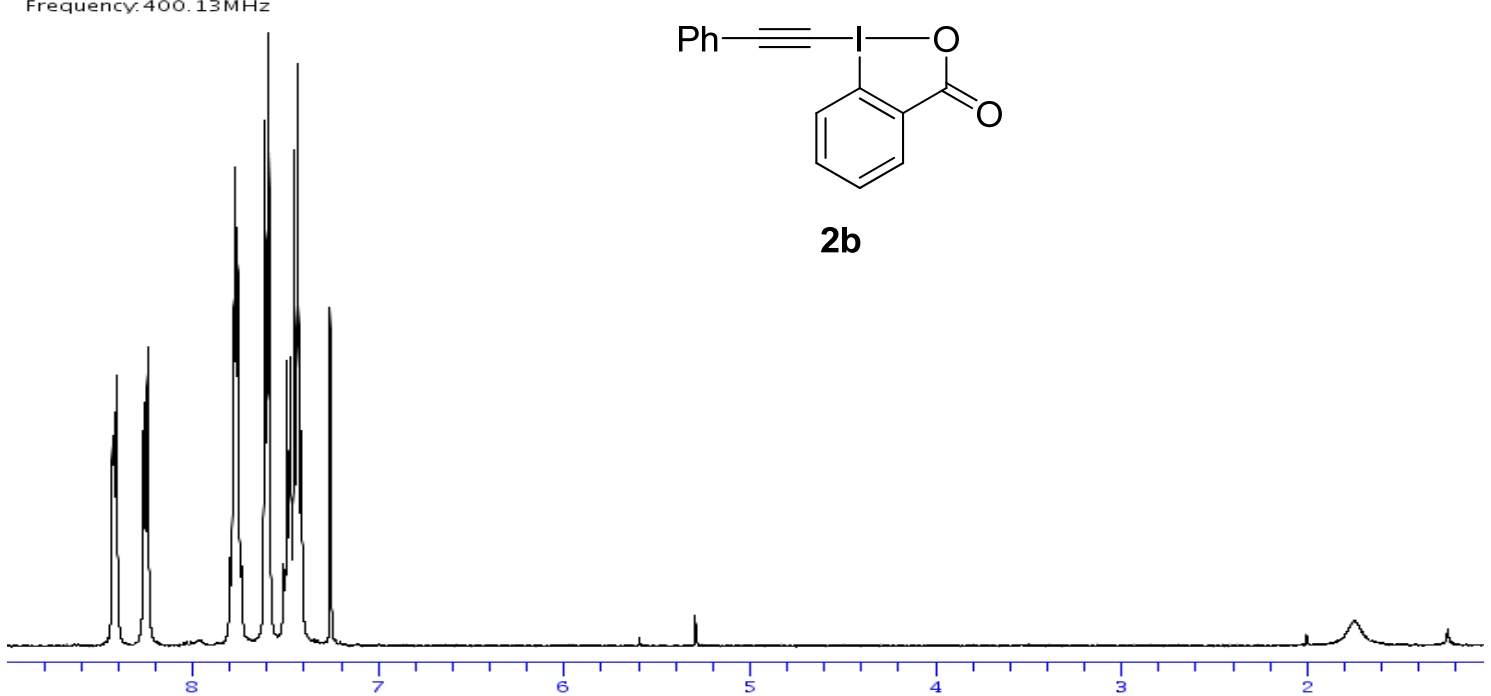

solvent: $\mathrm{CDCI}$

Frequencr.100. $61 \mathrm{MHz}$
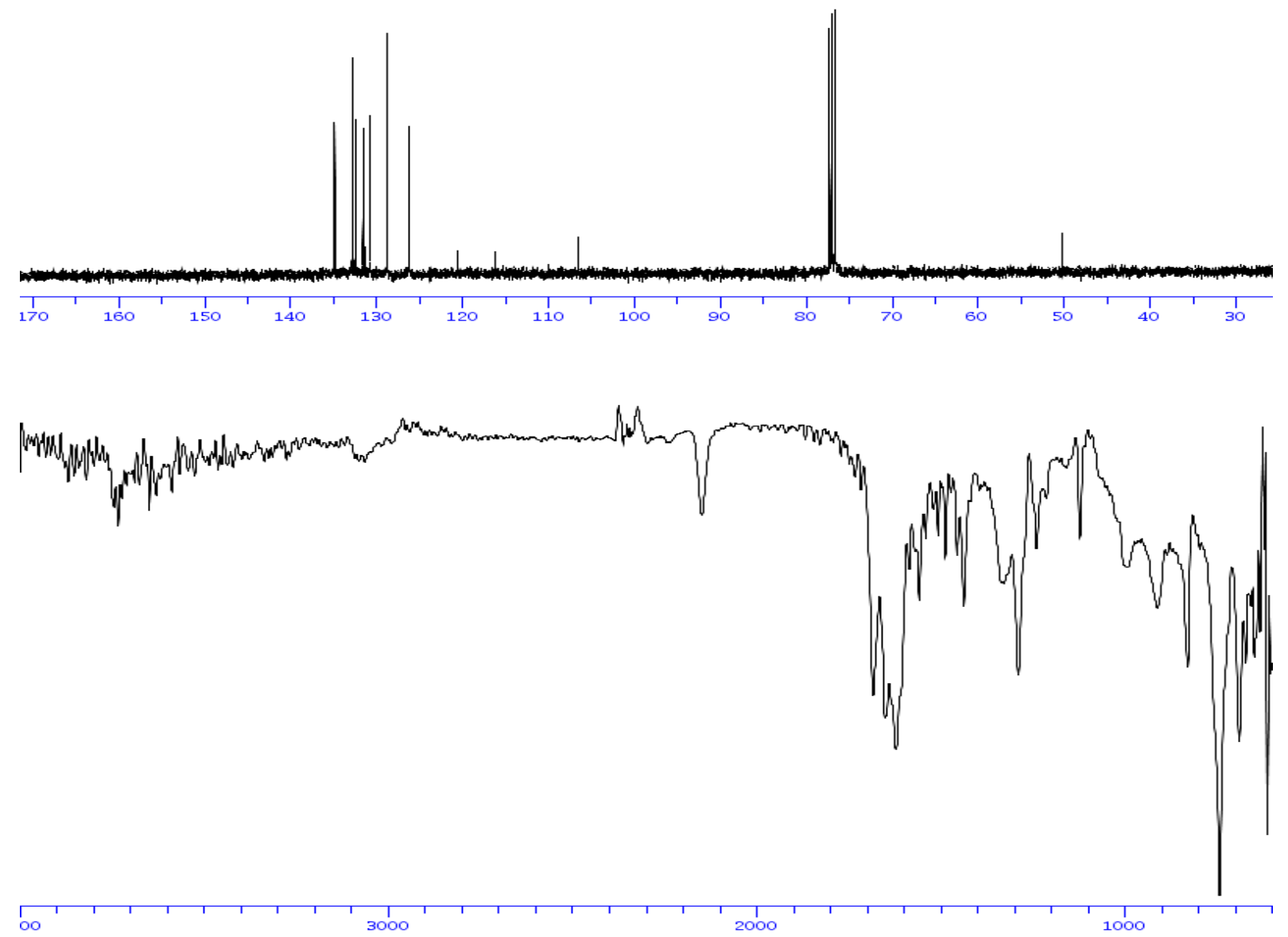
$N$-(4-Methoxyphenylsulfonyl)pent-4-enamide (1b)

solvent: $\mathrm{CDCl} 3$<smiles>C=CCCC(=O)NS(=O)c1ccc(OC)cc1</smiles>

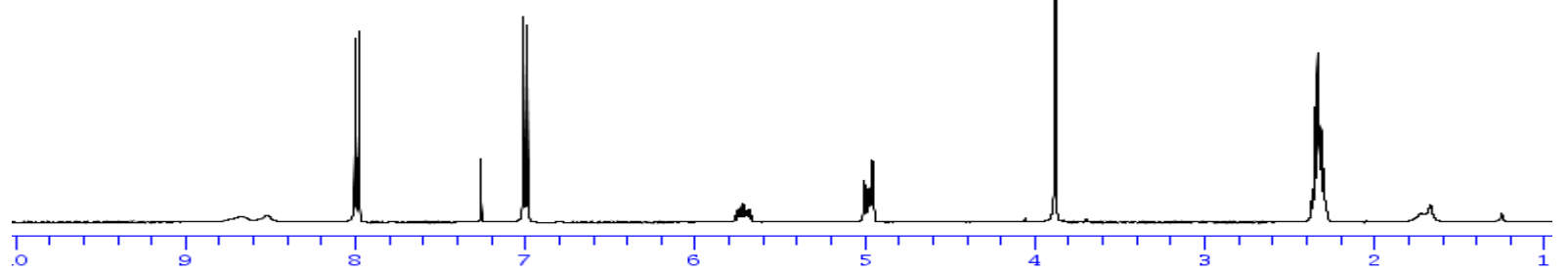

Frequency $100.61 \mathrm{MHz}$
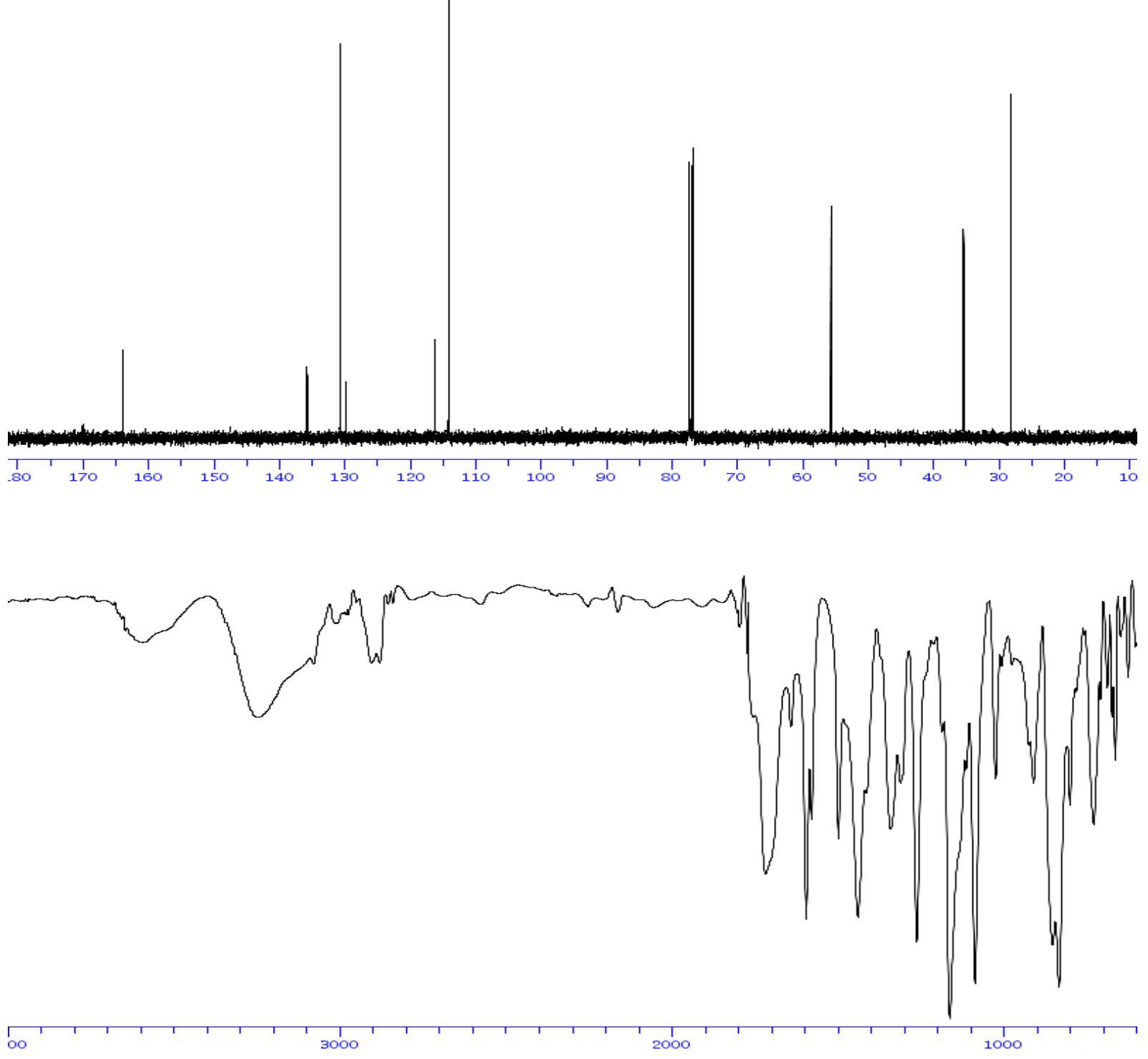
$N$-(4-Nitrophenylsulfonyl)pent-4-enamide (1c)

solvent:DMSO

$13 \mathrm{MHz}$<smiles>C=CCCC(=O)NS(=O)(=O)[O-]</smiles>

1c

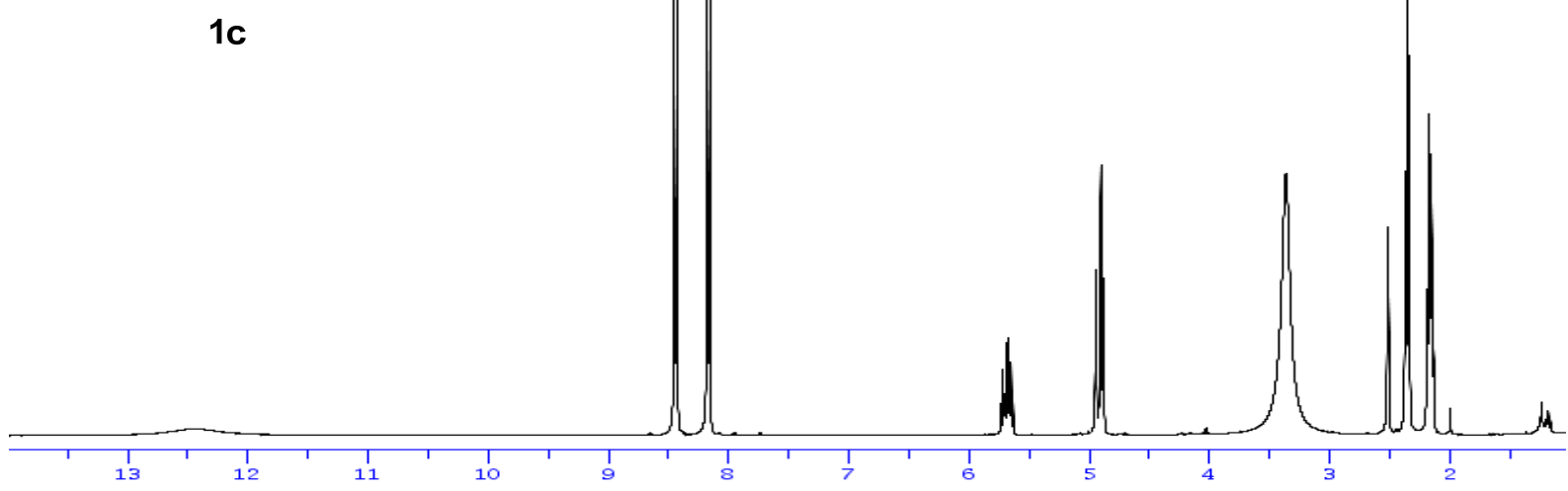

solvent:DMSO

Frequency. $100.61 \mathrm{MHz}$

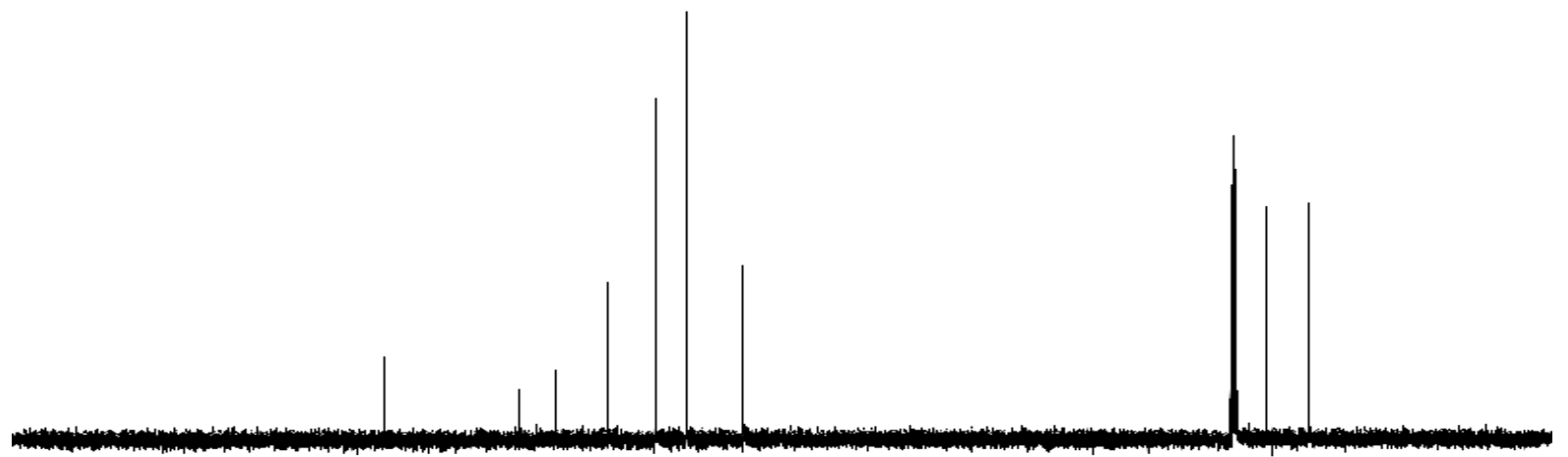

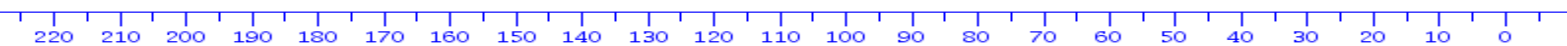
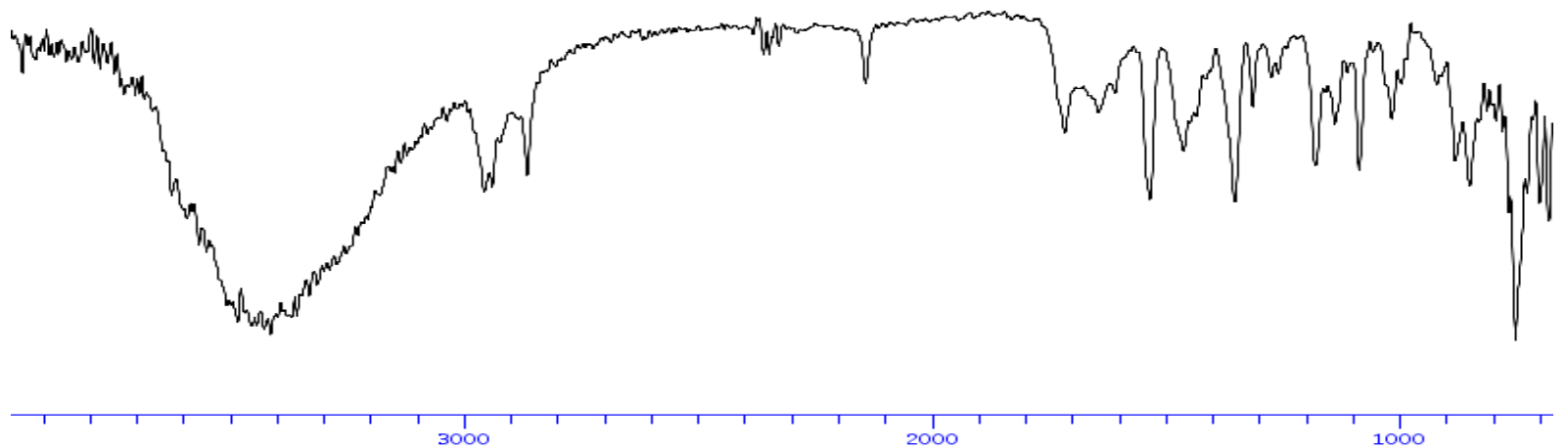


\section{2,2-Dimethyl- $N$-tosylpent-4-enamide (1d)}

solvent: $\mathrm{CDCl} 3$
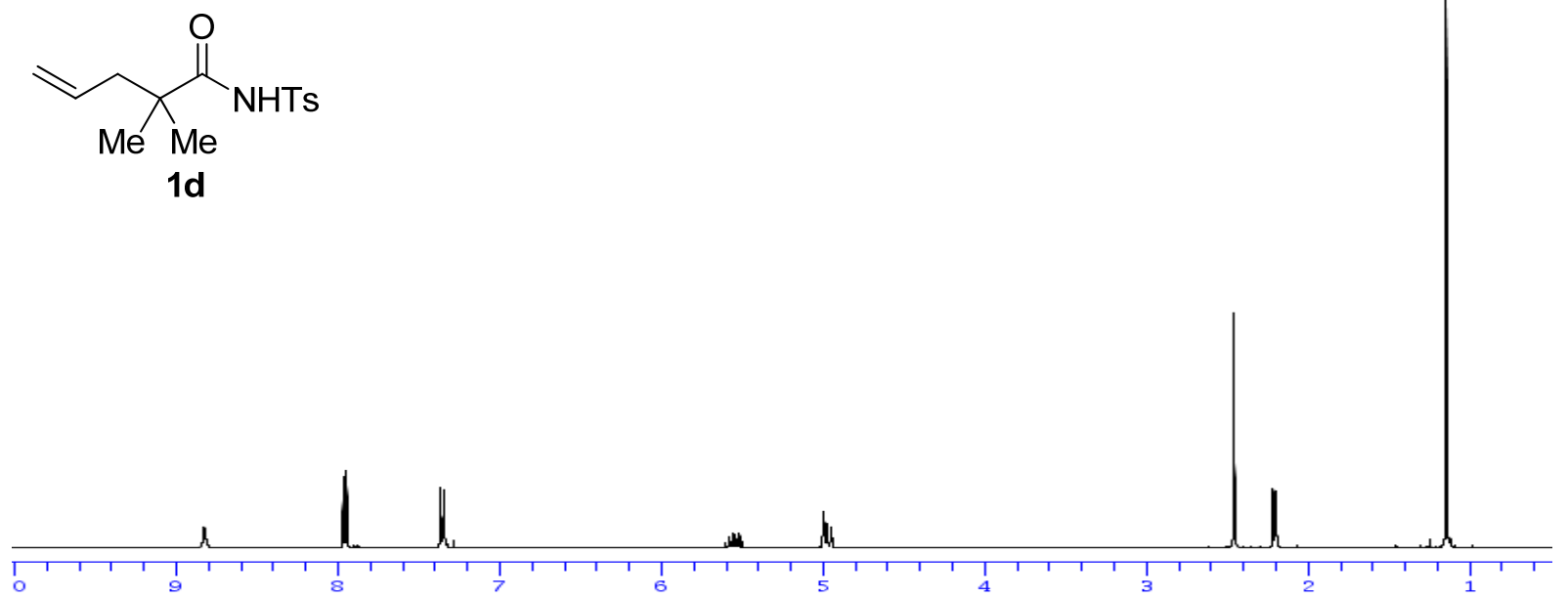

Frequency $100.13 \mathrm{MHz}$
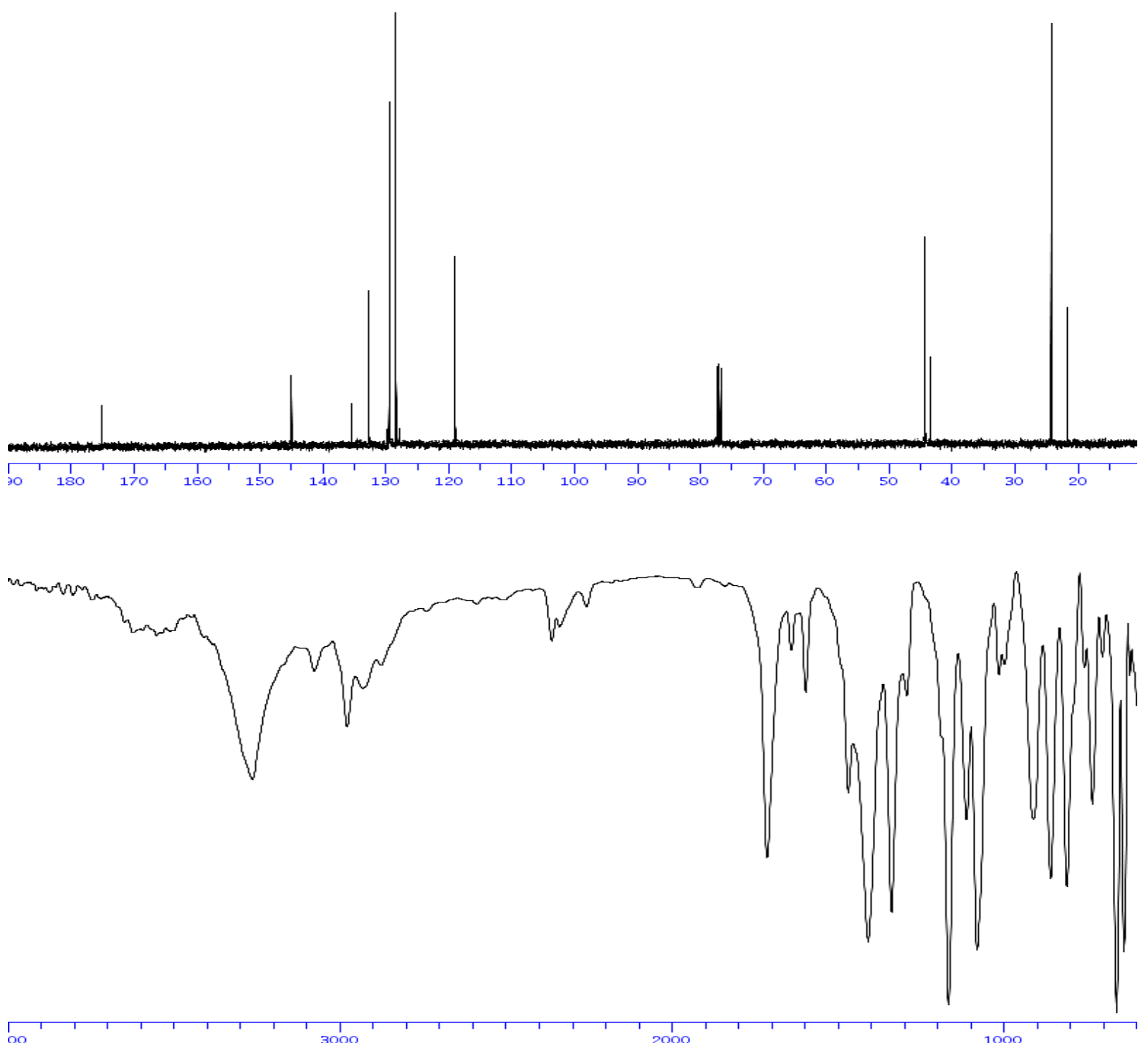


\section{1-Allyl- $N$-tosylcyclohexanecarboxamide (1e)}

solvent: $\mathrm{CDCl}$

Frequency $400.13 \mathrm{MHz}$
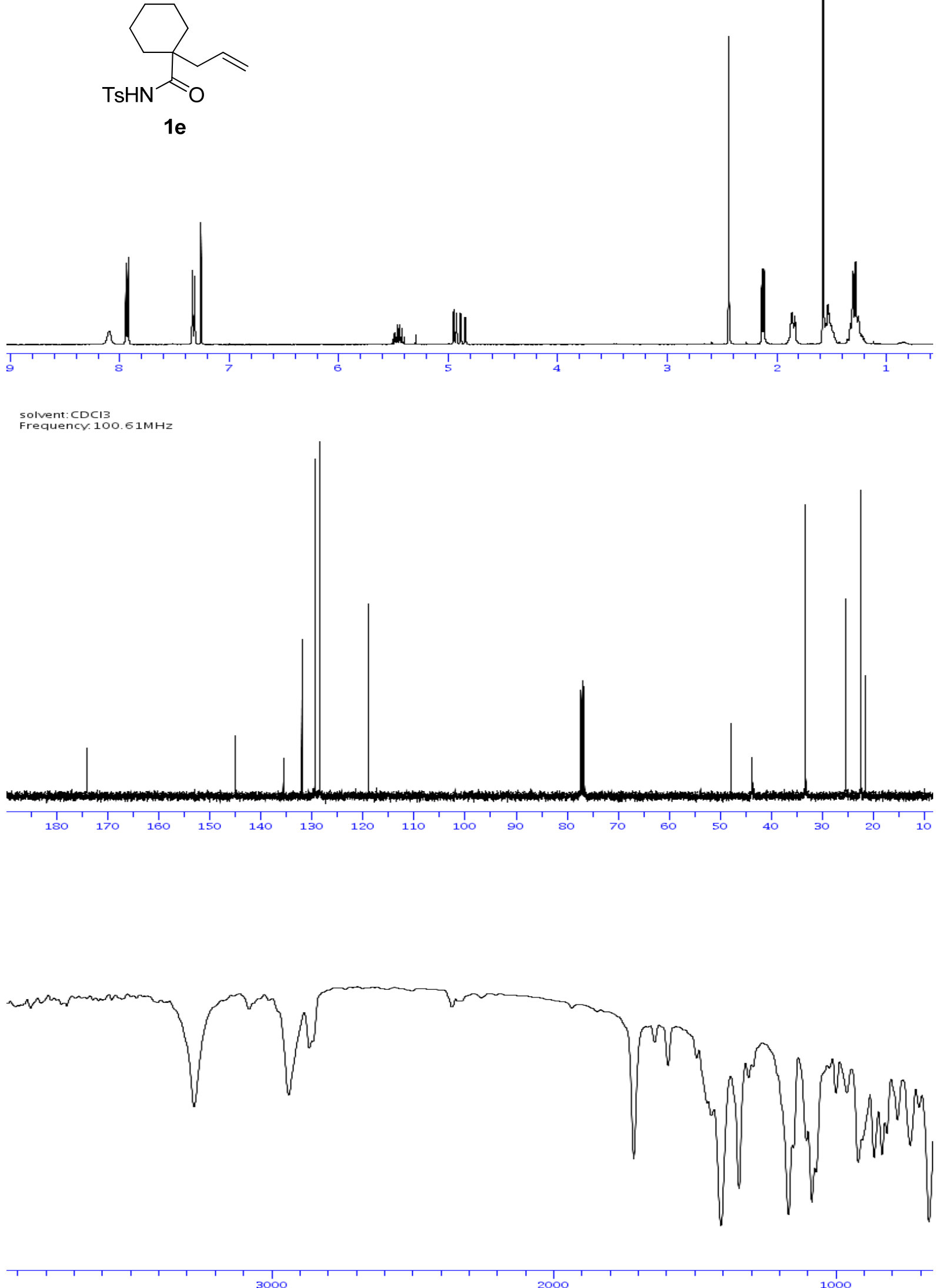
1-Allyl- $N$-tosylcyclopentanecarboxamide (1f)

Solvent: $\mathrm{CDCl}$
Frequency. $400.13 \mathrm{MHz}$
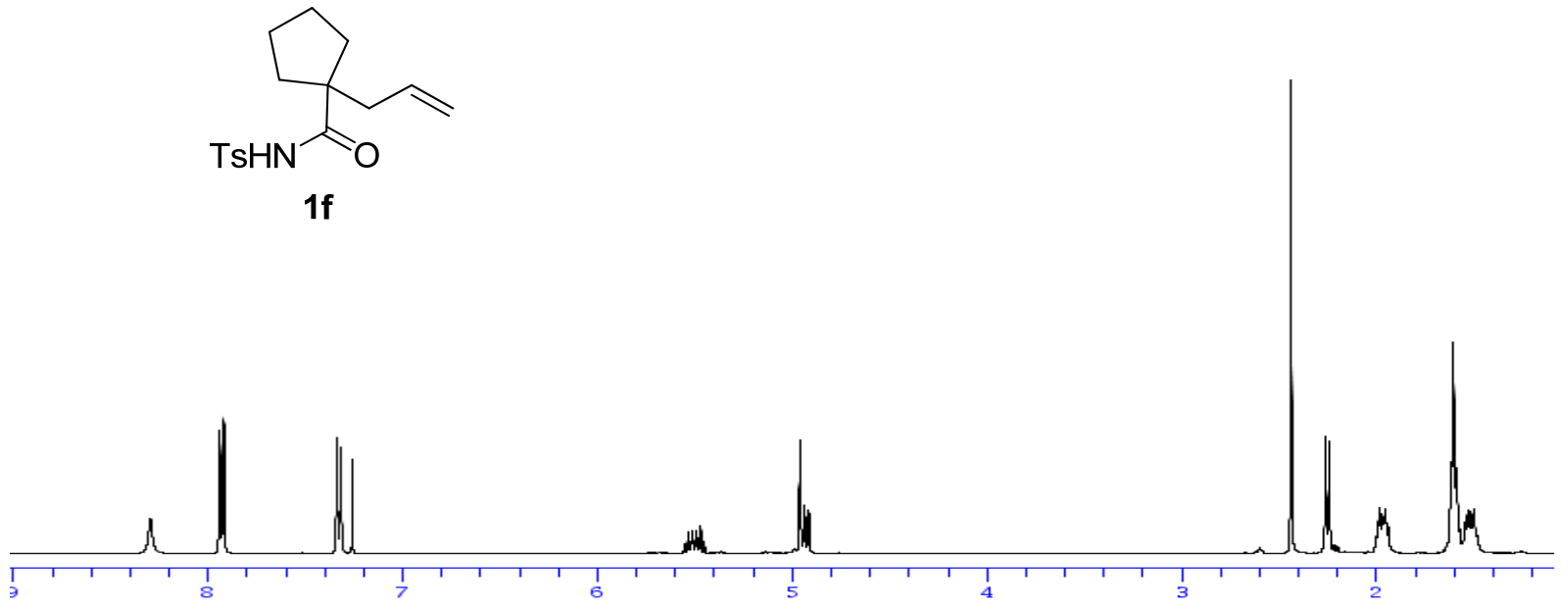

Solvent: $\mathrm{CDCI3}$
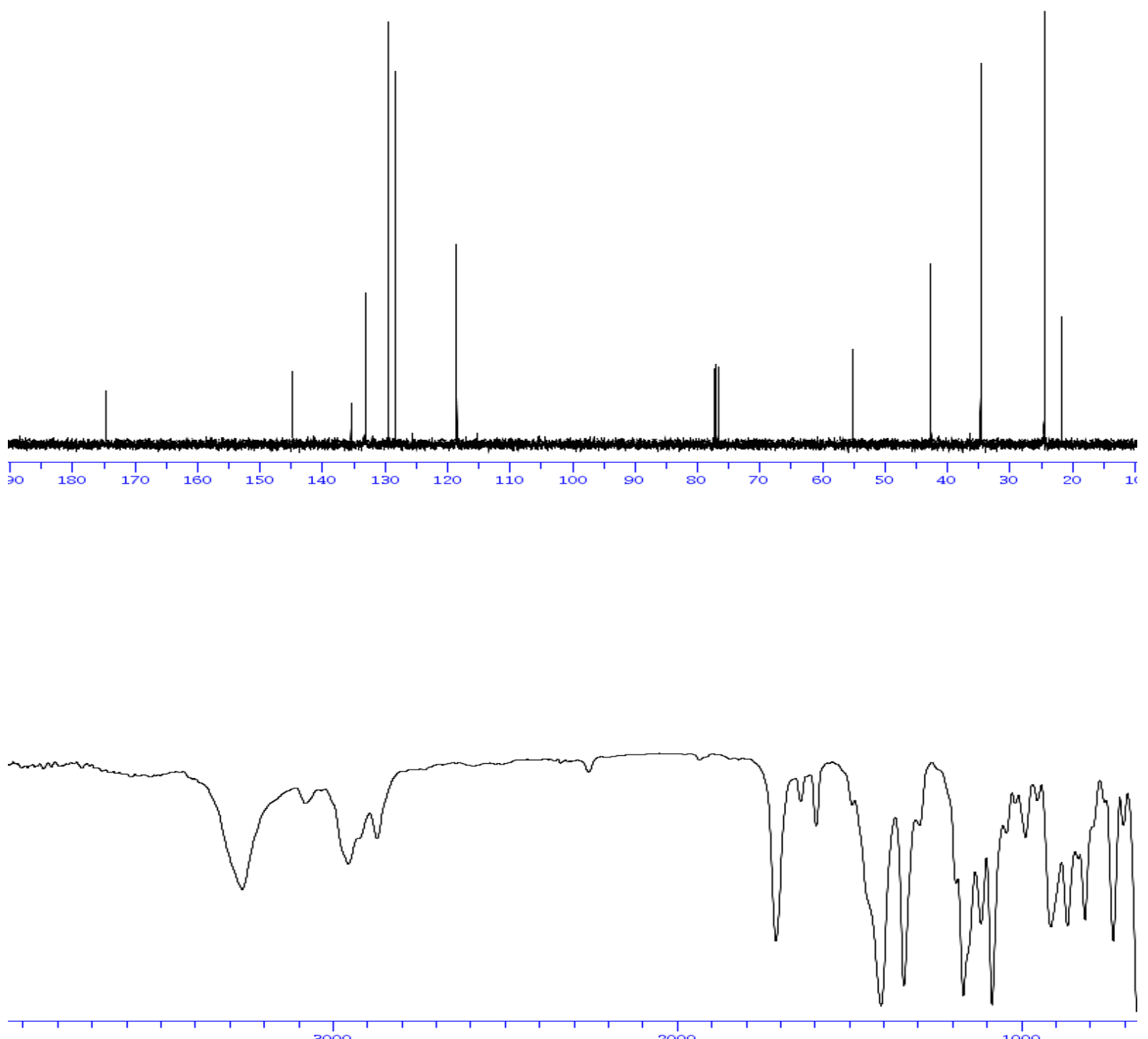
3-Phenyl- $N$-tosylpent-4-enamide (1g)

solvent: $\mathrm{CDCl} 3$<smiles>C=CC(CC(N)=O)c1ccccc1</smiles>

$1 \mathrm{~g}$

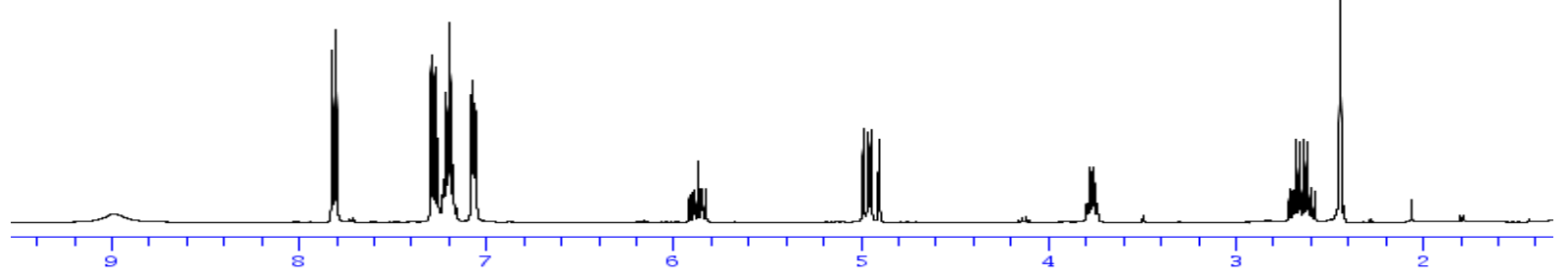

solvent: $C D C I 3$

Frequency. $100.61 \mathrm{MHz}$
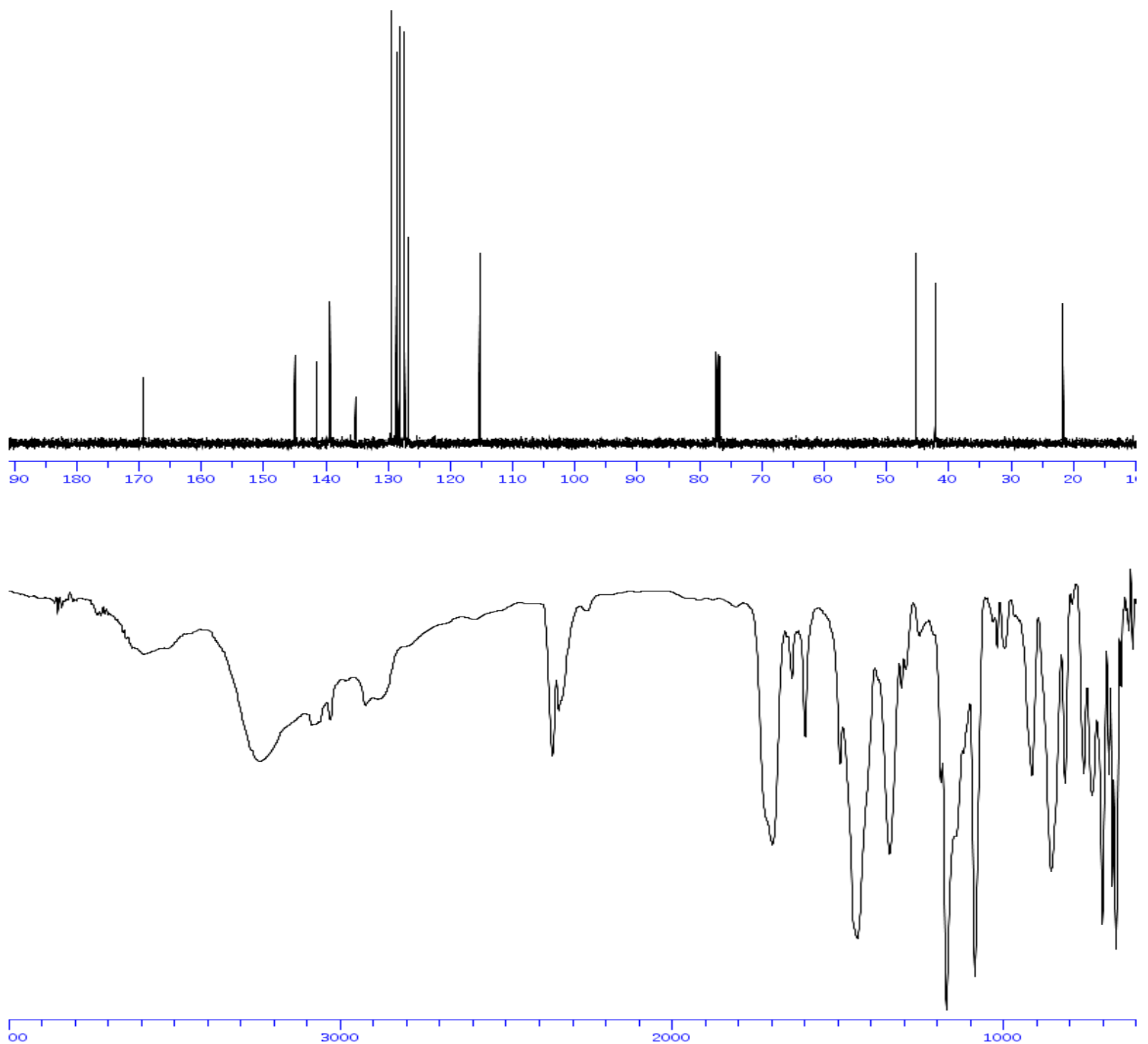
$\mathrm{N}$-Tosyl-2-vinylcyclohexanecarboxamide (1h)

solvent: $\mathrm{CDCl} 3$

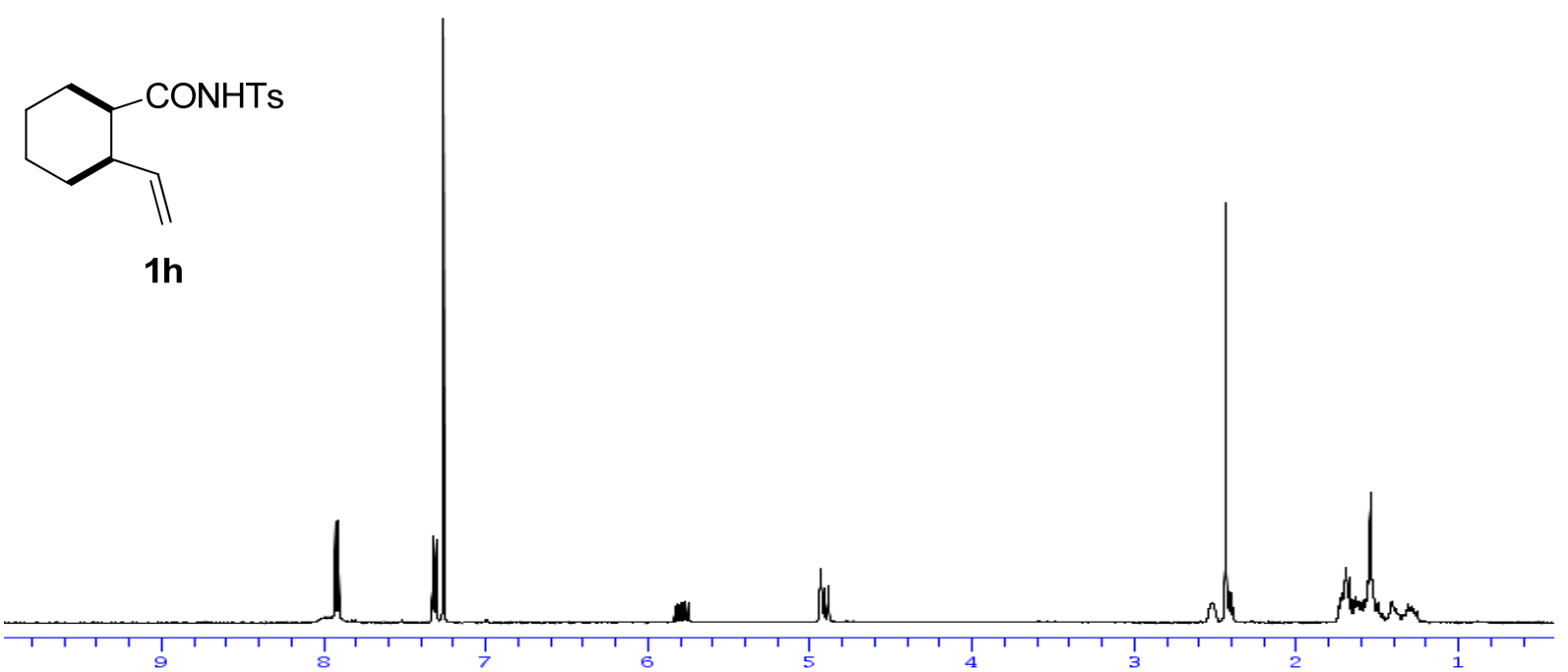

solvent: $\mathrm{CDCI} 3$

$100.61 \mathrm{MHz}$
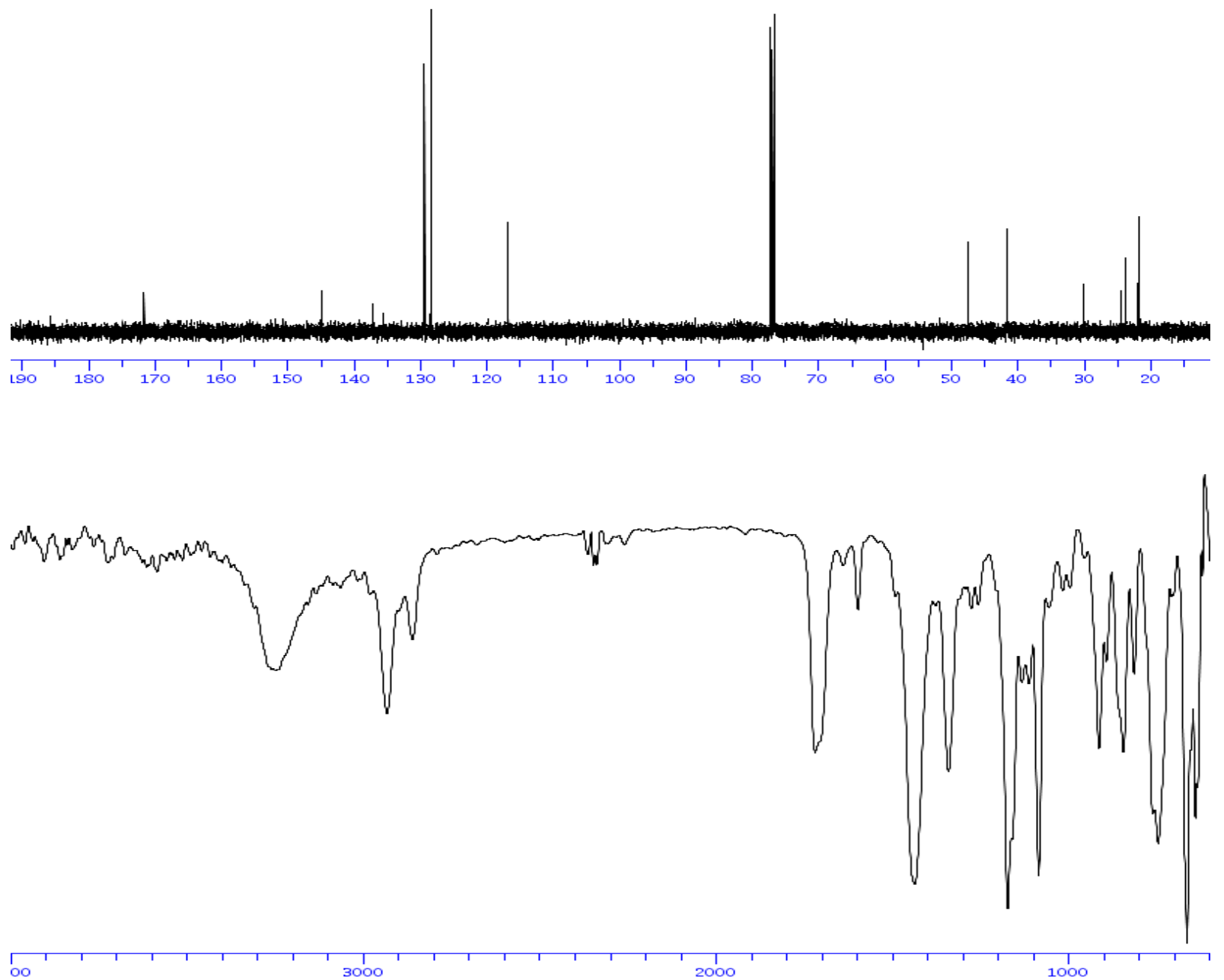


\section{$N$-Tosylhex-5-enamide (1i)}

solvent: $\mathrm{CDCI} 3$

Frequency $400.13 \mathrm{MHz}$<smiles>C=CCCCC(=O)NC(F)(F)F</smiles>

$1 i$

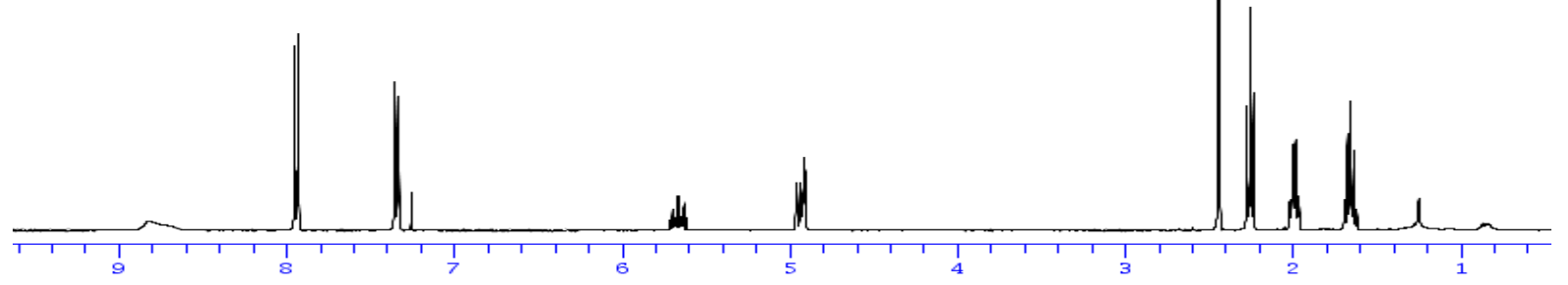

solvent: $\mathrm{CDCl} 3$
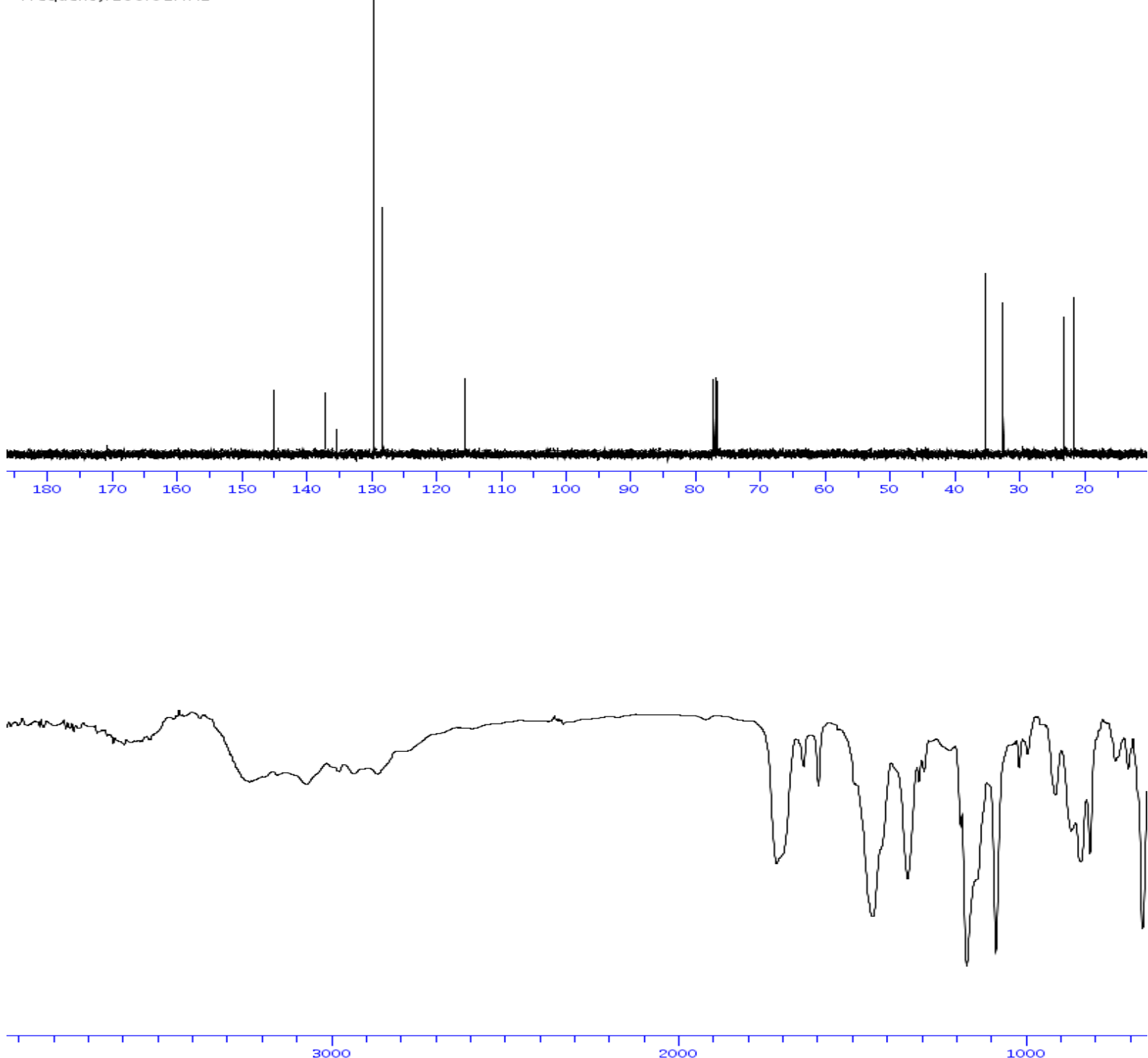


\section{2-Allyl- $N$-tosylbenzamide (1j)}

solvent: $\mathrm{CDCl} 3$

Frequency. $400.13 \mathrm{MHz}$

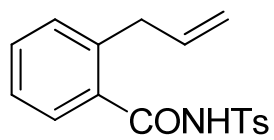

1j

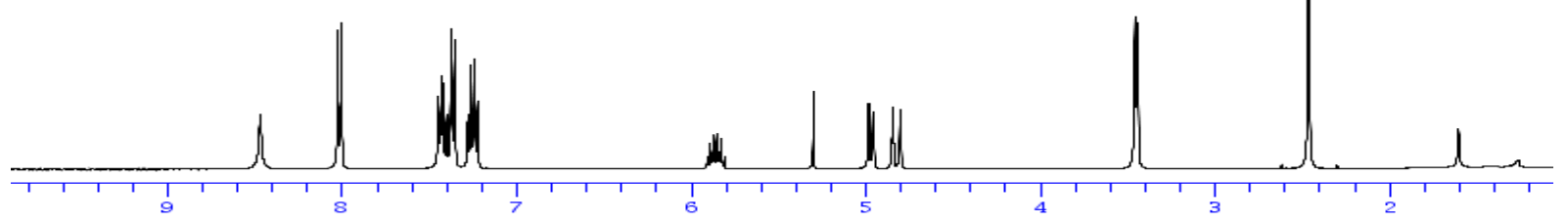

Tsolvent: $\mathrm{CDCl} 3 \mathrm{MHz}$
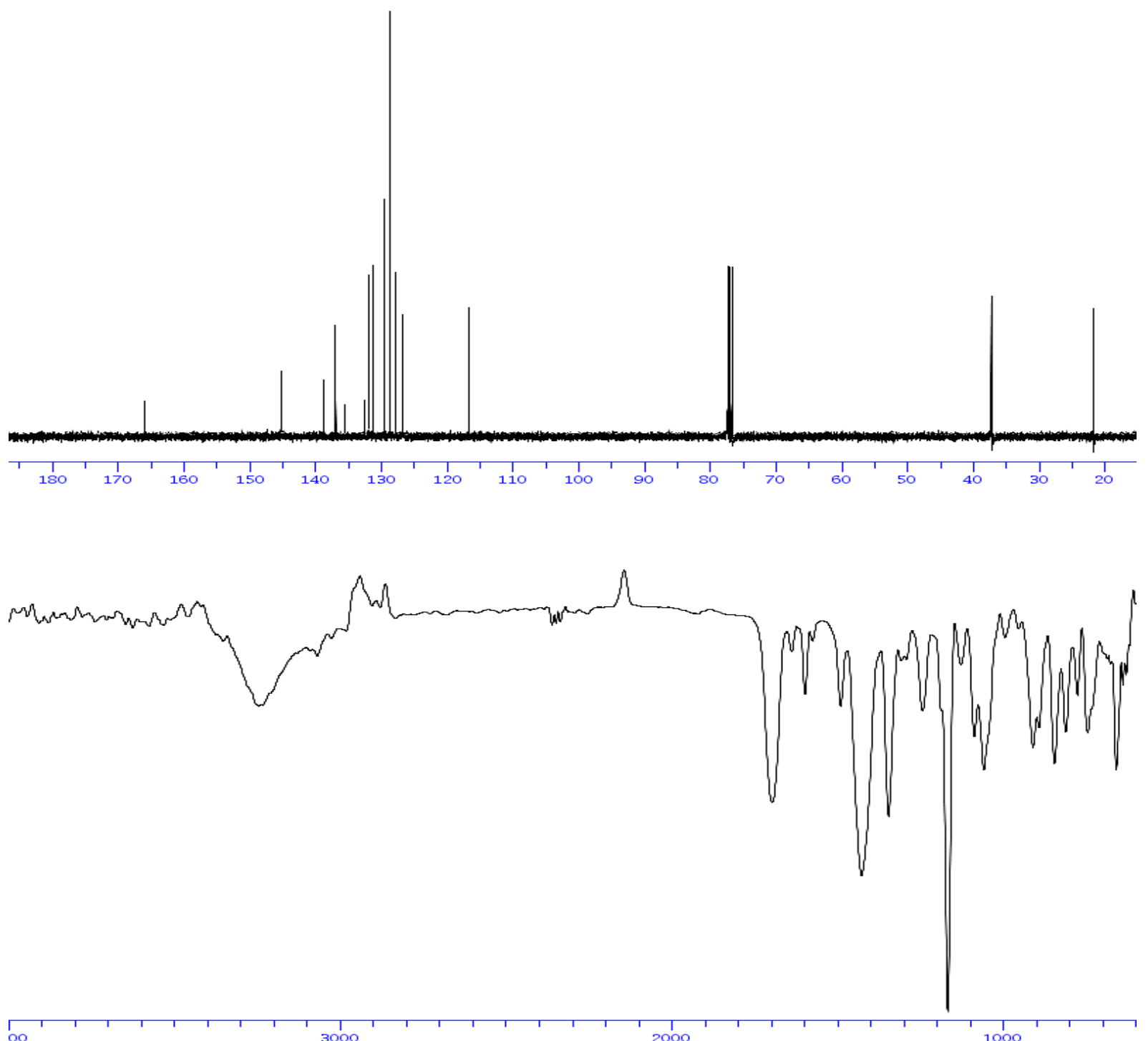
1-Allyl- $N$-tosyl-1H-pyrrole-2-carboxamide (1k)

solvent: $\mathrm{CDCl} 3$

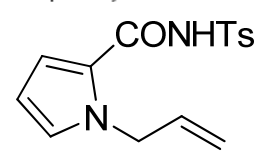

$1 \mathrm{k}$

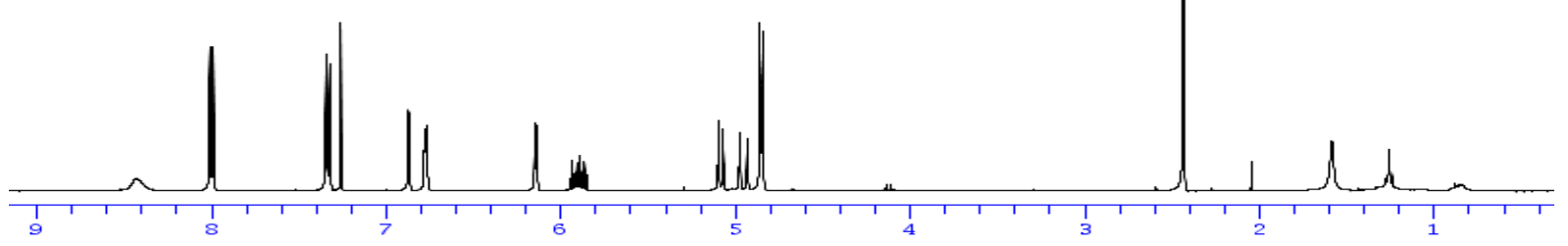

solvent: $C D C 13$

Frequency.100. $11 \mathrm{MHz}$
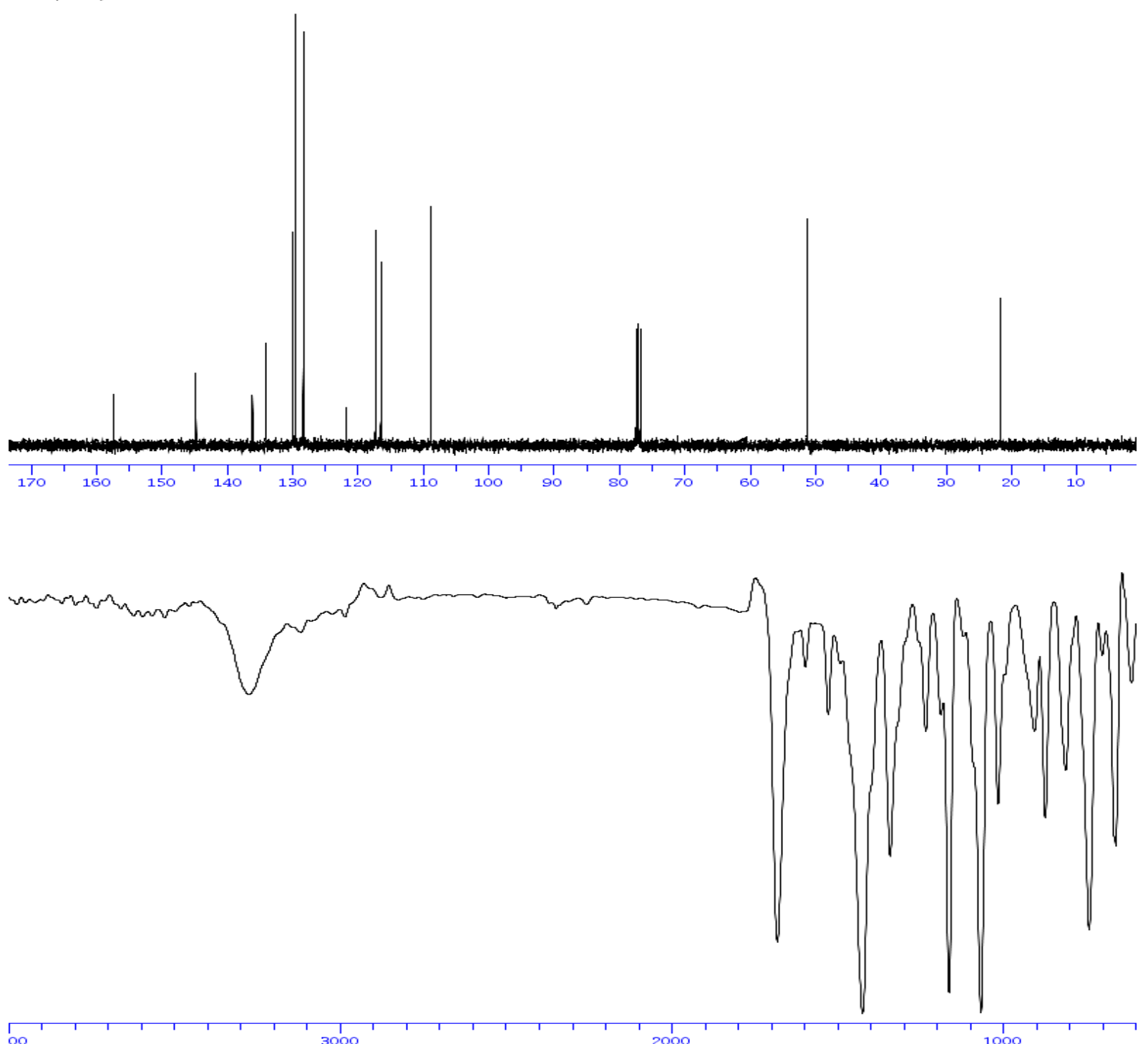
1-Allyl- $\mathrm{N}$-tosyl-1H-indole-2-carboxamide (11)

solvent: $\mathrm{CDCl} 3$

Frequency. $400.13 \mathrm{MHz}$<smiles>C=CCn1c(C(=O)N[In])cc2ccccc21</smiles>

11

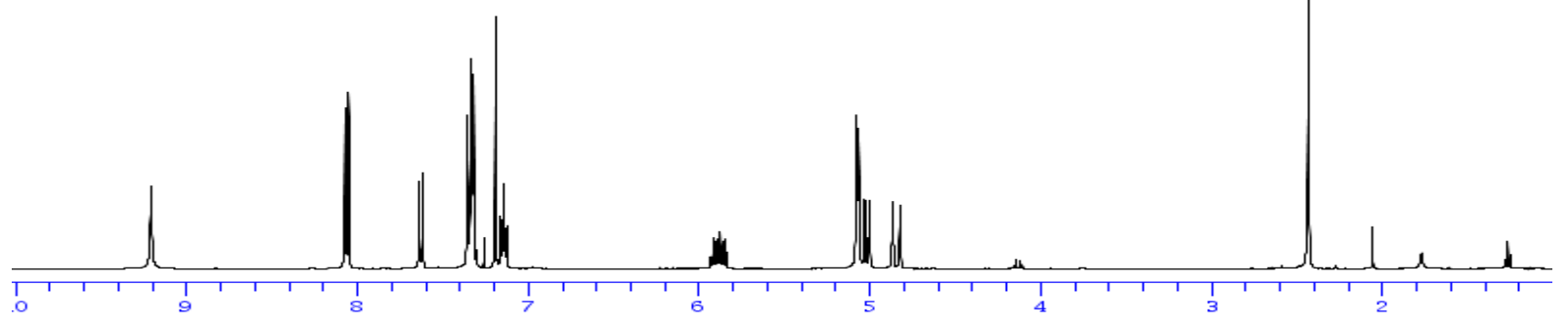

Solvent: $\mathrm{CDCI}$
Frequency. $100.61 \mathrm{MHz}$
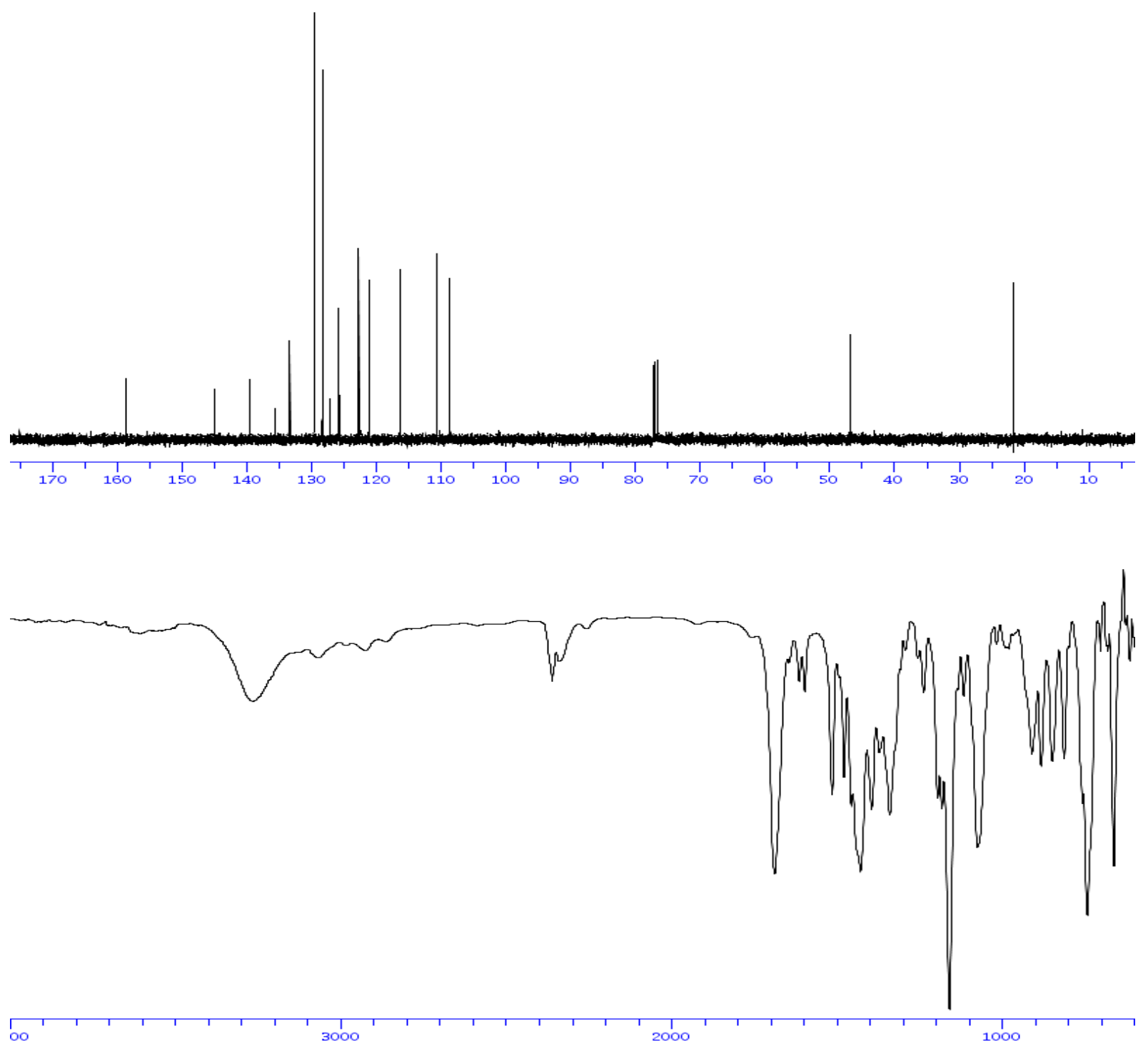


\section{4-methyl- $N$-(4-nitrophenylsulfonyl)pent-4-enamide (1m)}

solvent: $\mathrm{CDCl}$<smiles>C=C(C)CCC(=O)NNS(=O)(=O)[O-]</smiles>

$1 \mathrm{~m}$

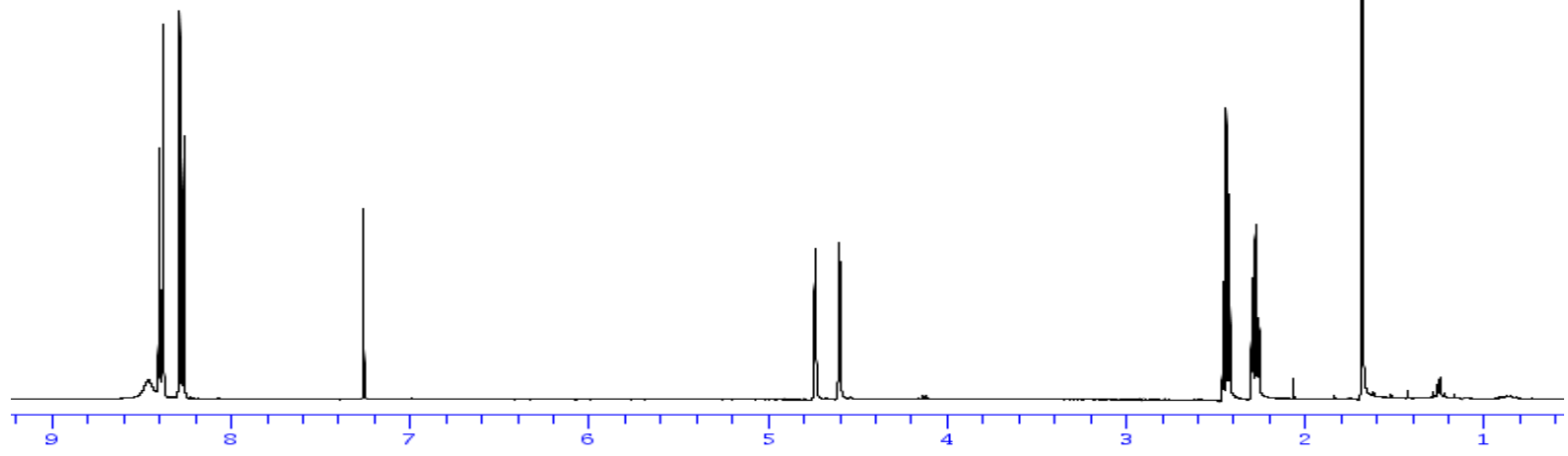

Solvent: $\mathrm{CDCI3}$
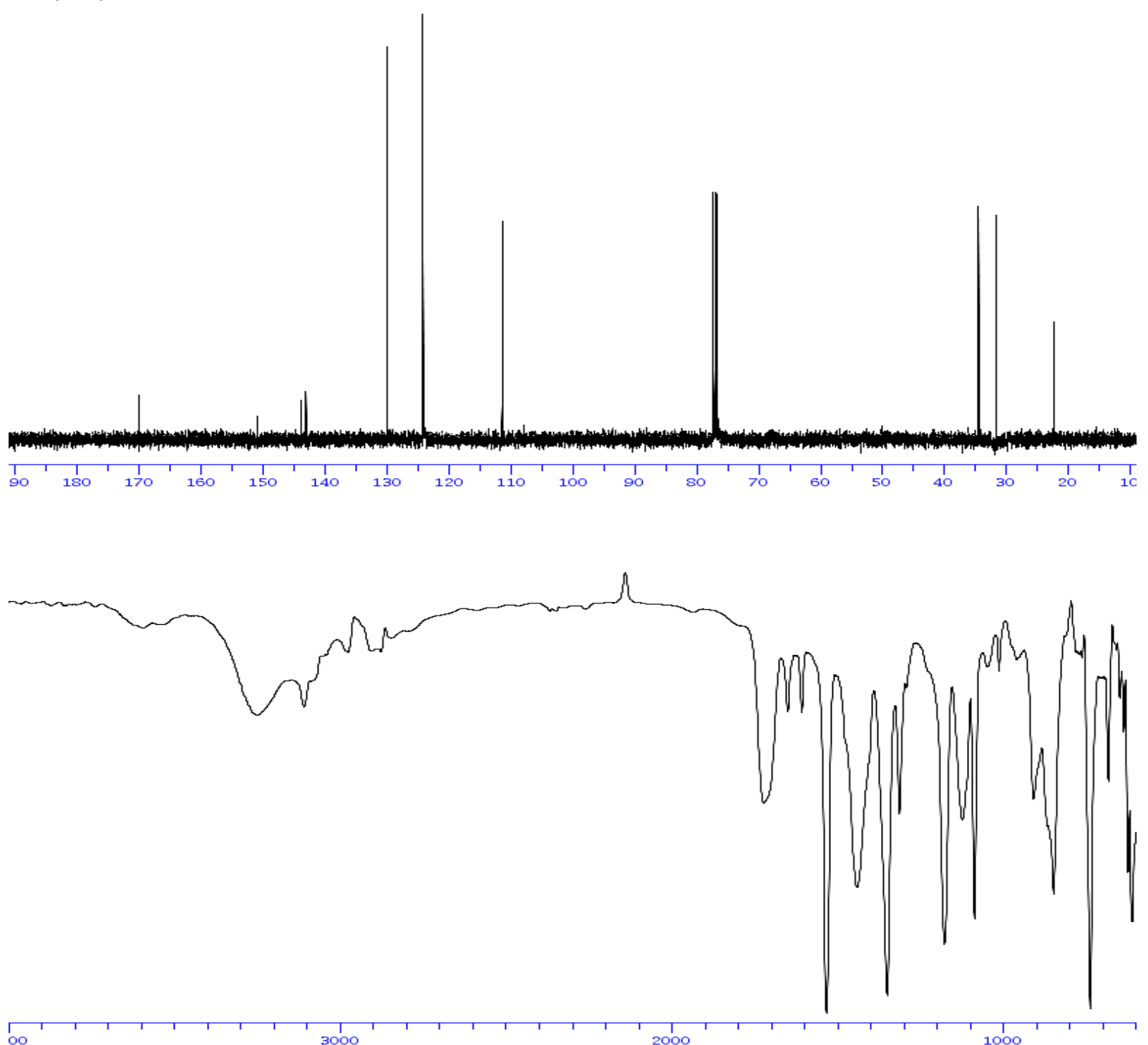
But-3-en-2-yl tosylcarbamate (6b)

$\overbrace{\mathrm{Me}}^{\mathrm{O}} \prod_{\mathrm{O}}^{\mathrm{NHT}}$

6b

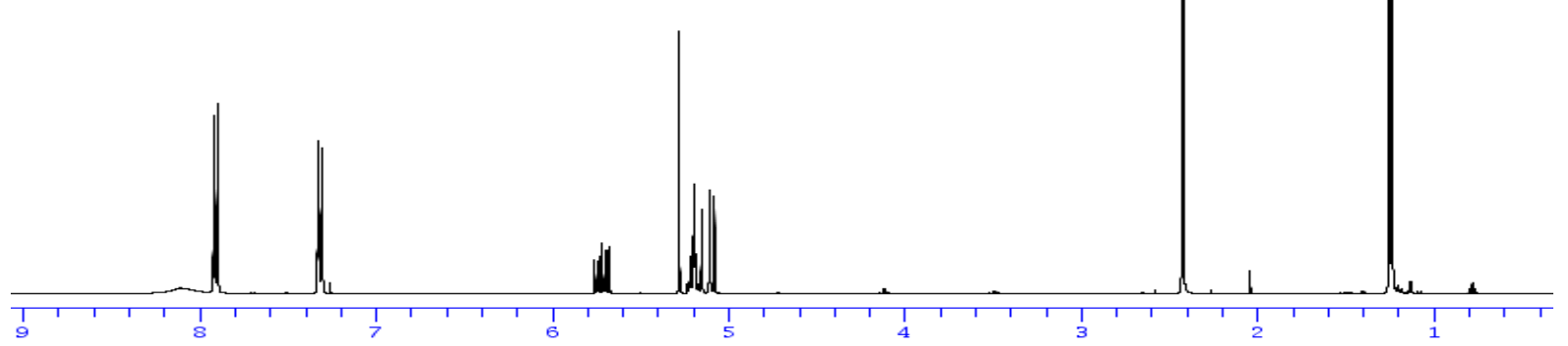

solvent: $C D C 13$

Frequency $100.61 \mathrm{MHz}$
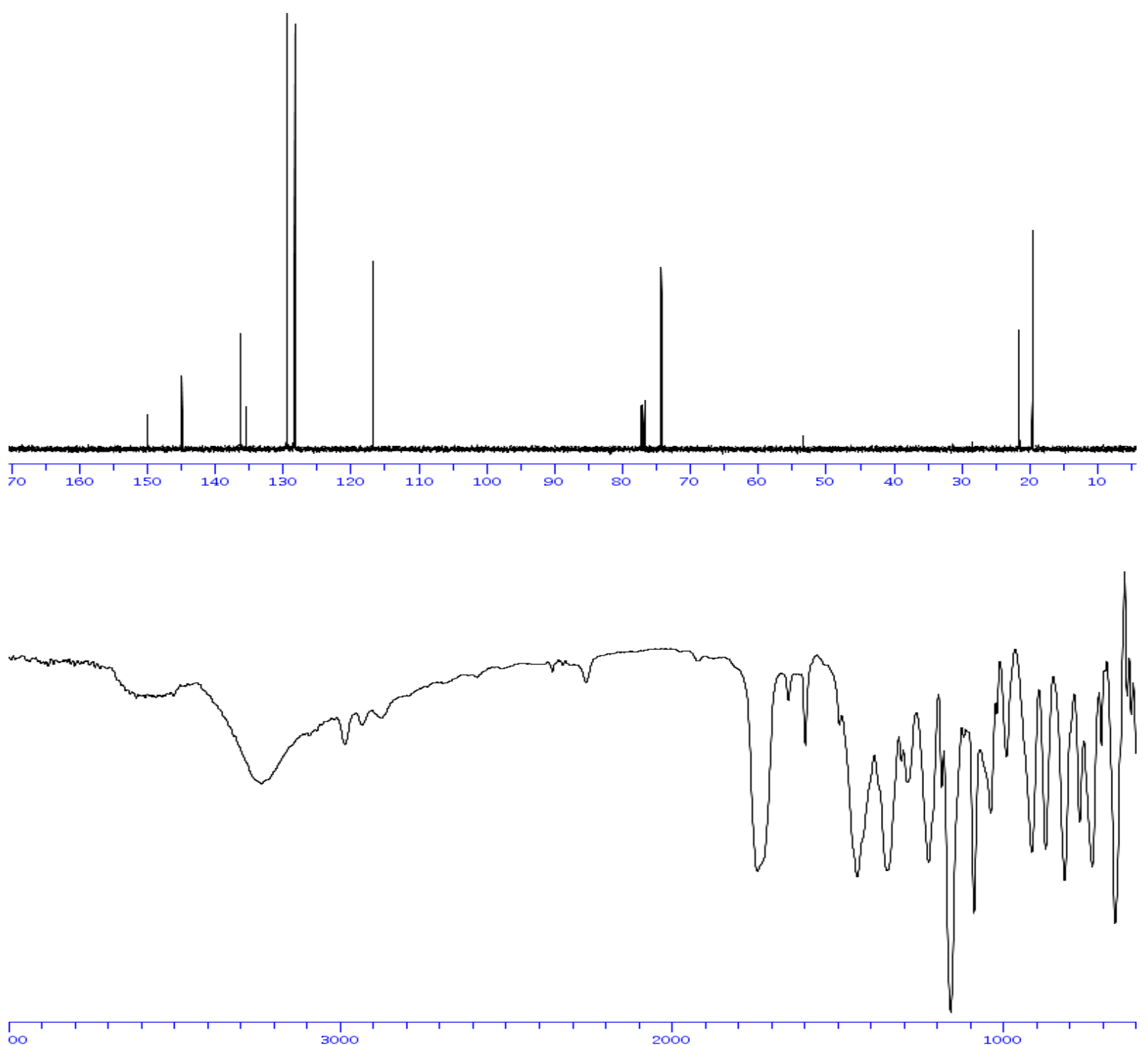
1-Cyclohexylallyl tosylcarbamate (6c)

solvent: $\mathrm{CDCI} 3$<smiles>C=CC(OC(=O)N[18F])C1CCCCC1</smiles>

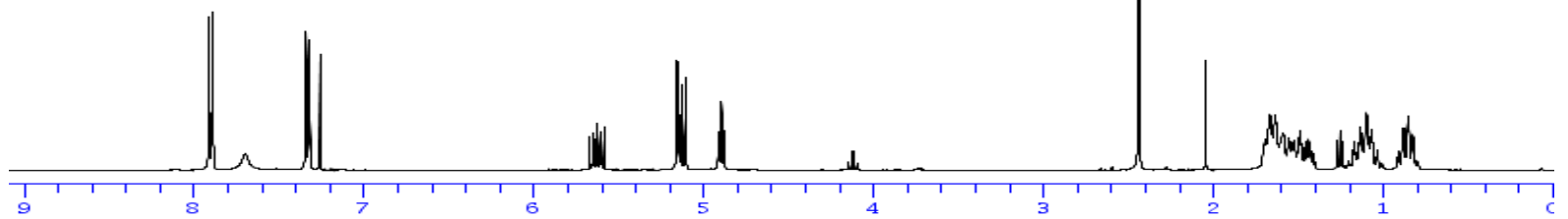

Frequency $100.61 \mathrm{MHz}$
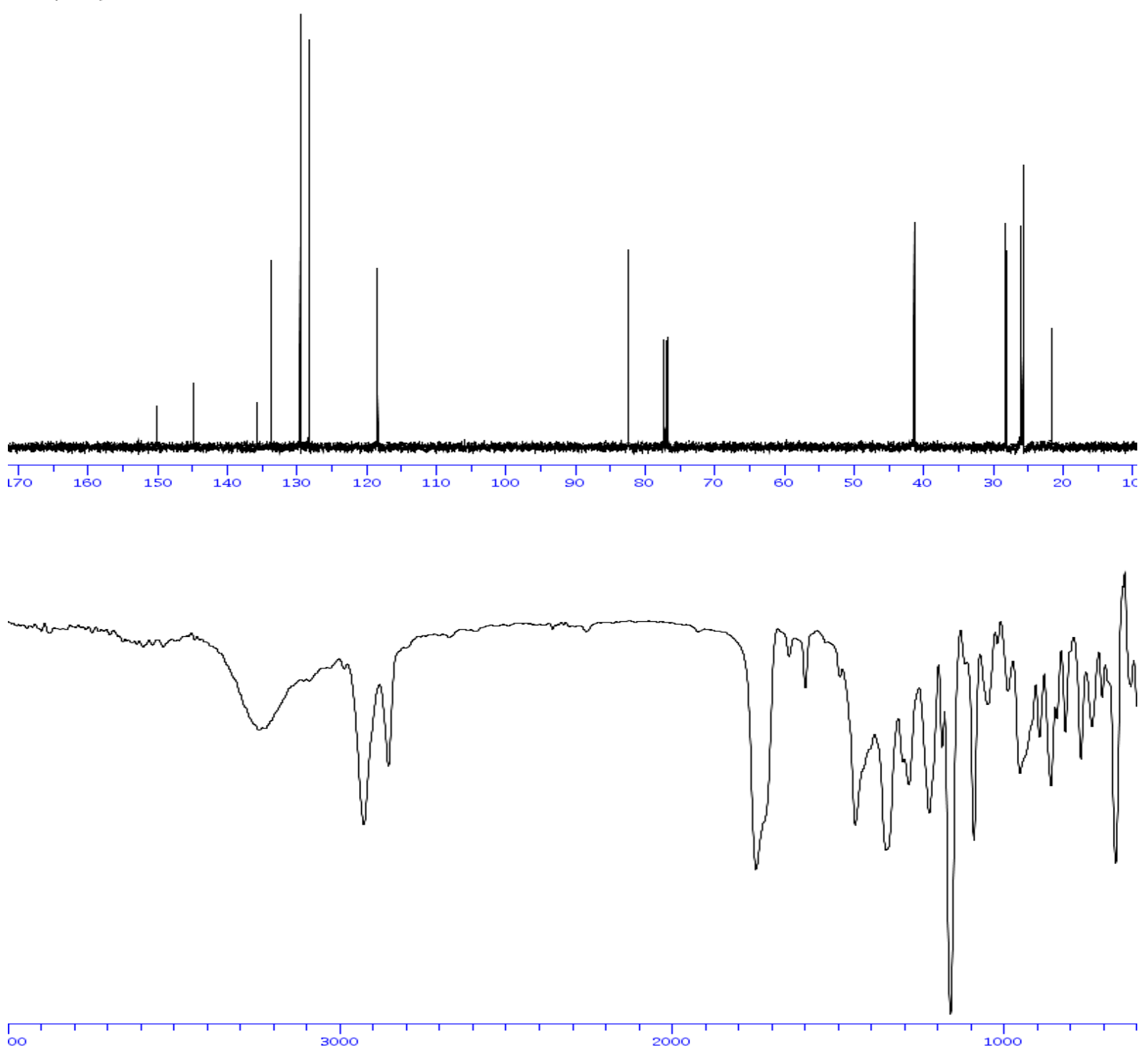
$N$-(Allylcarbamoyl)-4-methylbenzenesulfonamide (6e)

solvent: $\mathrm{CDCl} 3$

CY. $400.13 \mathrm{MHz}$<smiles>C=CCNC(=O)NC</smiles>

$6 e$

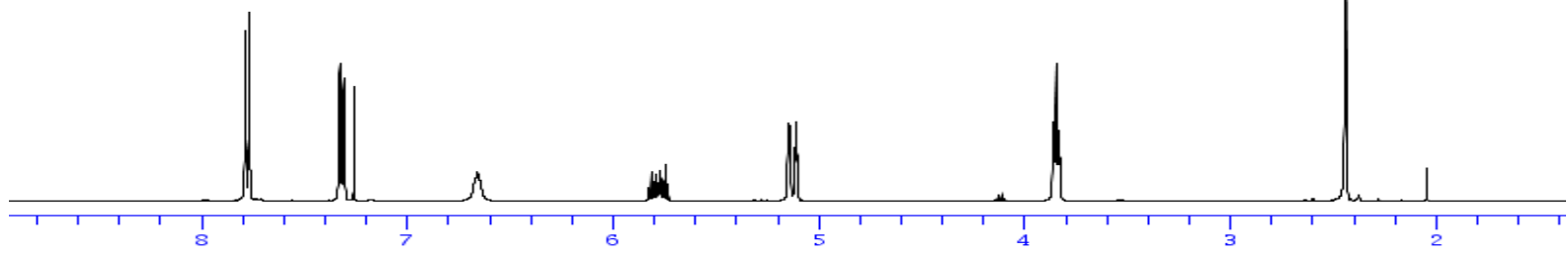

solvent: $\mathrm{CDCI} 3$

Frequencr. $100.61 \mathrm{MHz}$
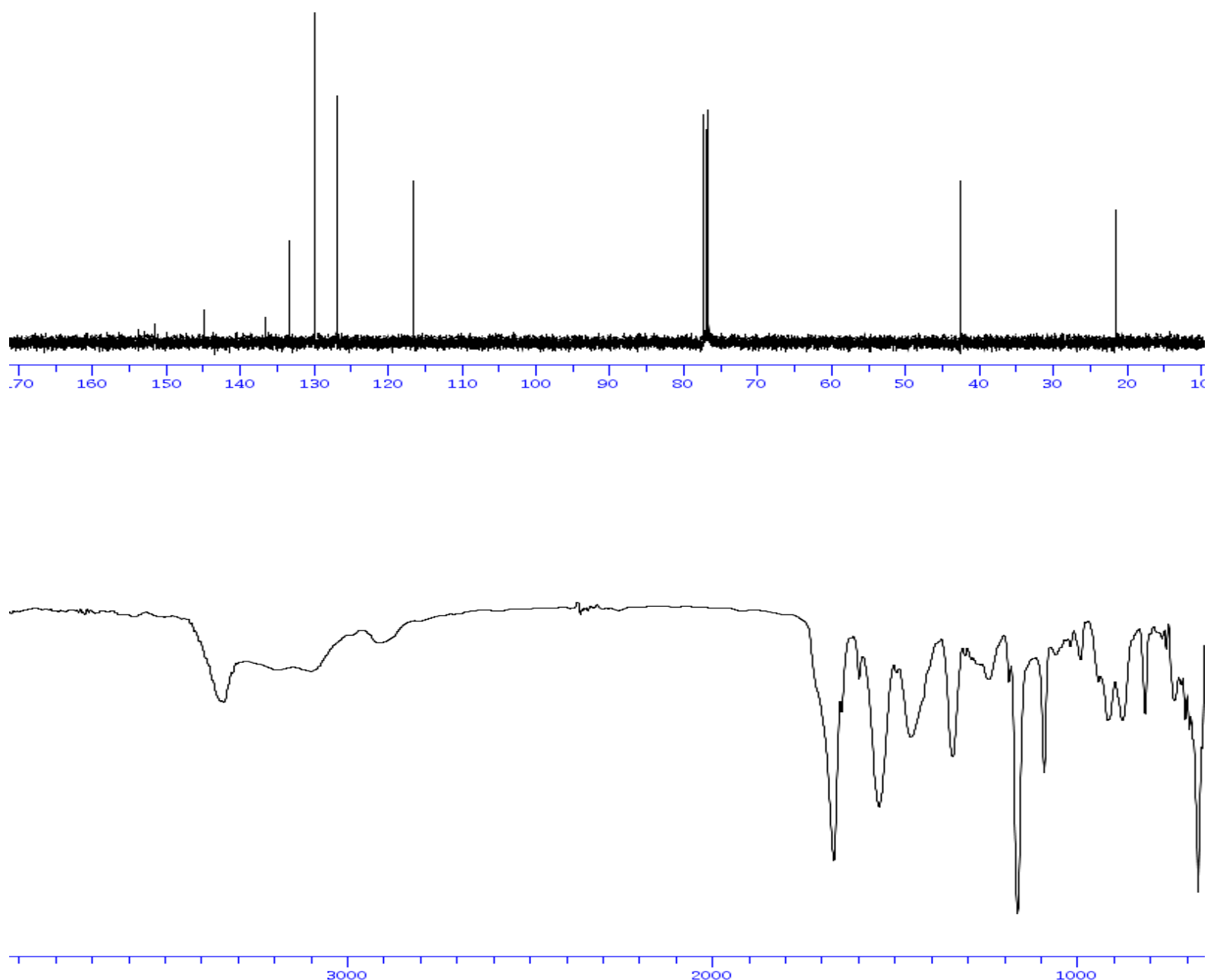
$N$-(Diallylcarbamoyl)-4-methylbenzenesulfonamide (6f)

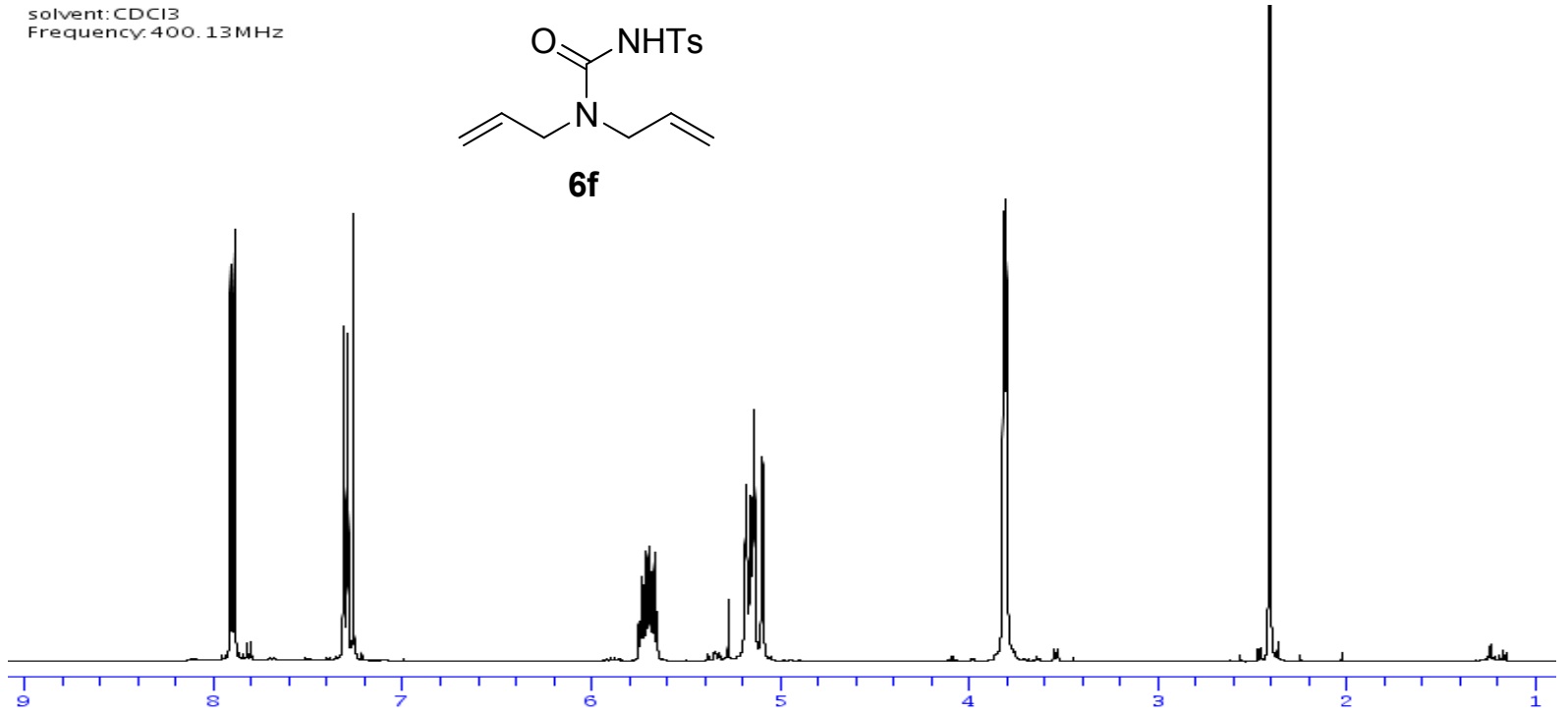

Frequency $100.61 \mathrm{MHz}$
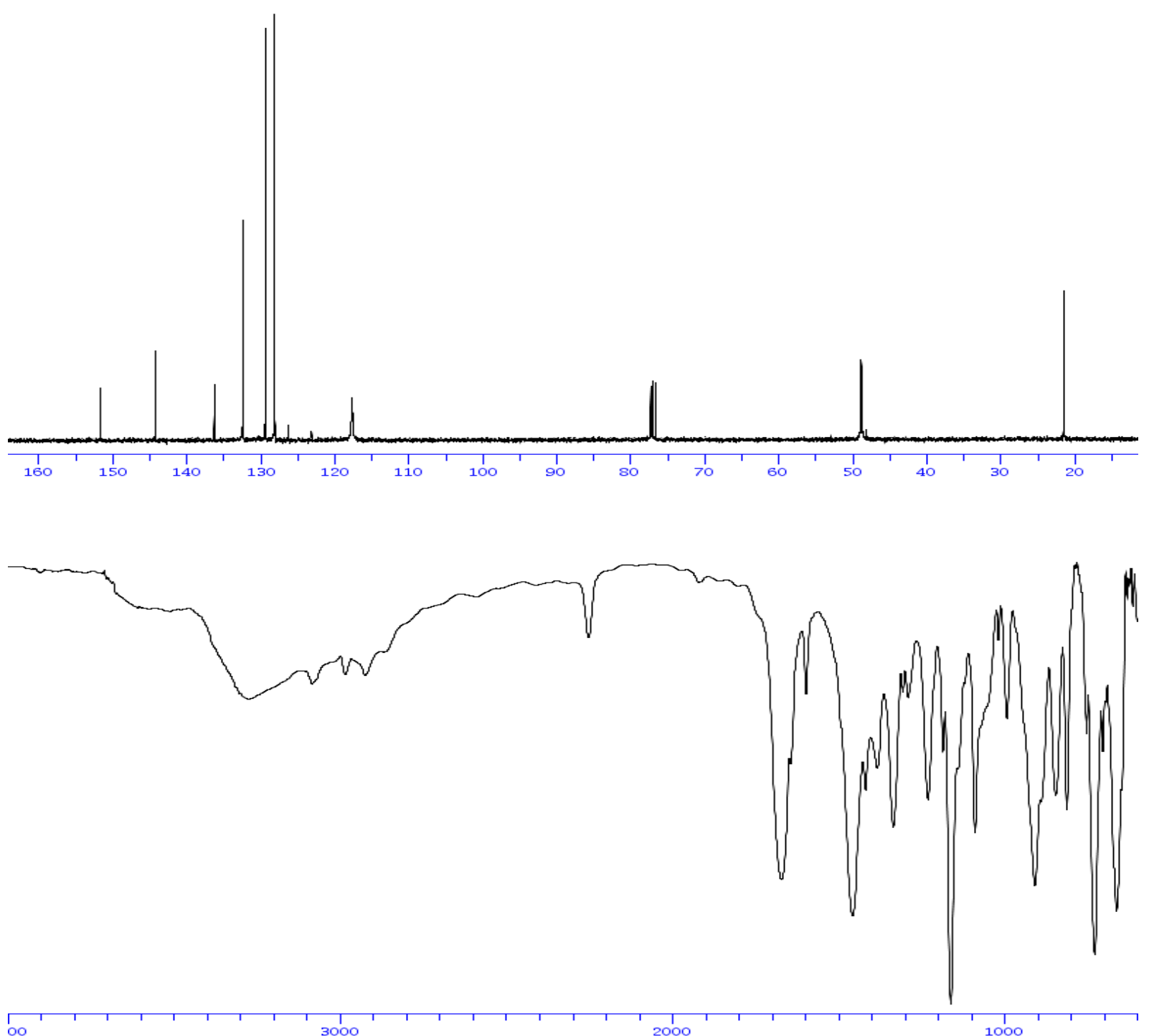


\section{2-Benzyl- $N$-tosylpent-4-enamide (6g)}

solvent: $\mathrm{CDCl} 3$

Frequency $400.13 \mathrm{MHz}$<smiles>C=CCN(Cc1ccccc1)C(=O)NC(F)(F)F</smiles>

$6 \mathrm{~g}$

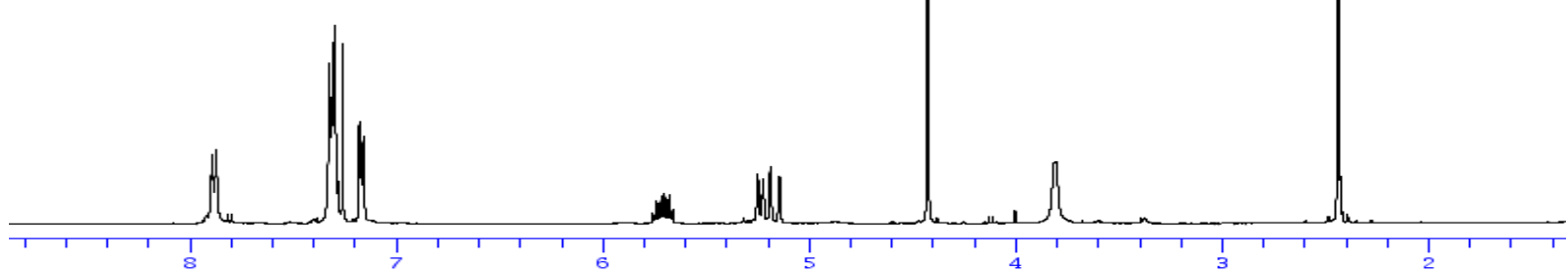

solvent: $\mathrm{CDCI} 3$

Frequency $100.61 \mathrm{MHz}$
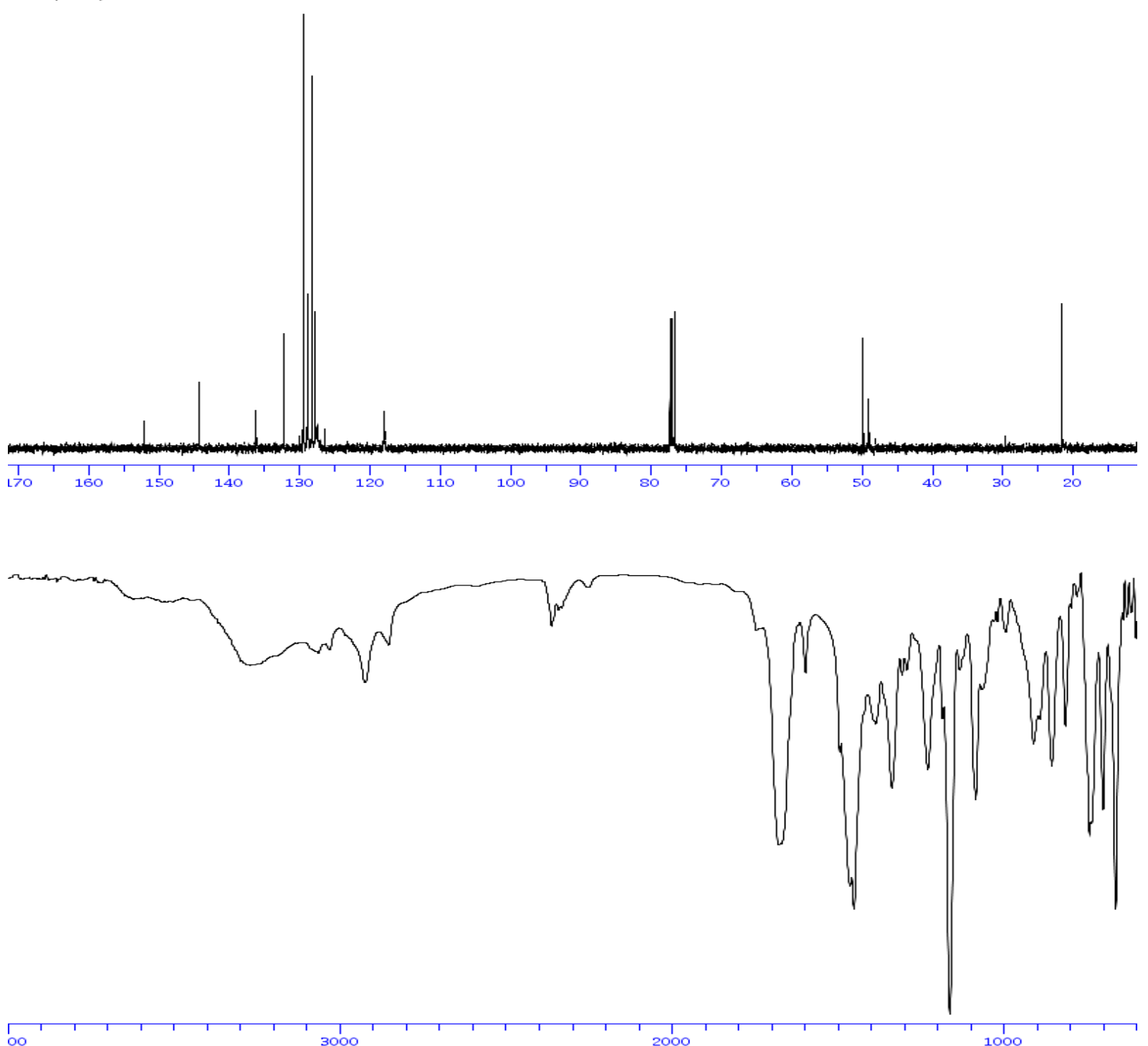
1-Tosyl-5-(3-(triisopropylsilyl)prop-2-ynyl)pyrrolidin-2-one (3a)

solvent: $\mathrm{CDCI} 3$
Frequency. $400.13 \mathrm{MHz}$

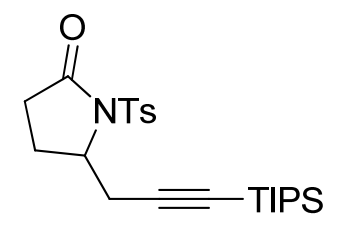

$3 a$

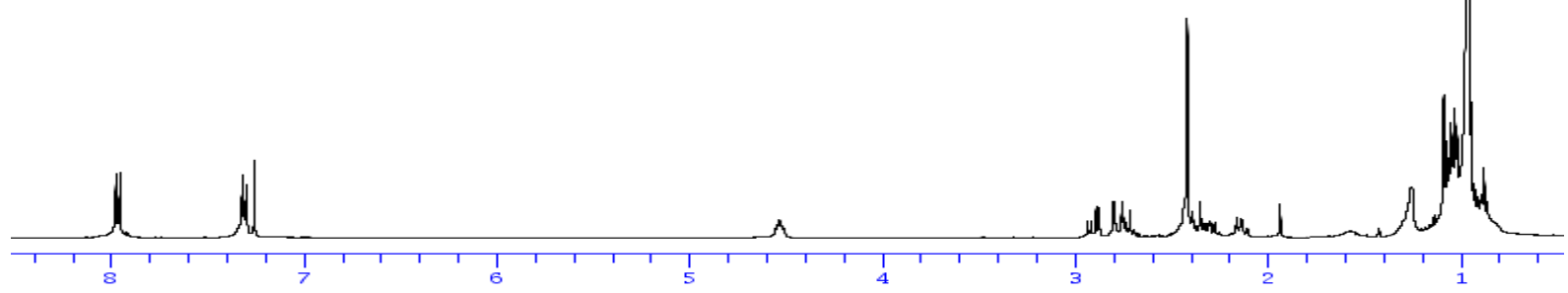

solvent: $\mathrm{CDCI}$

. $11 \mathrm{MHz}$
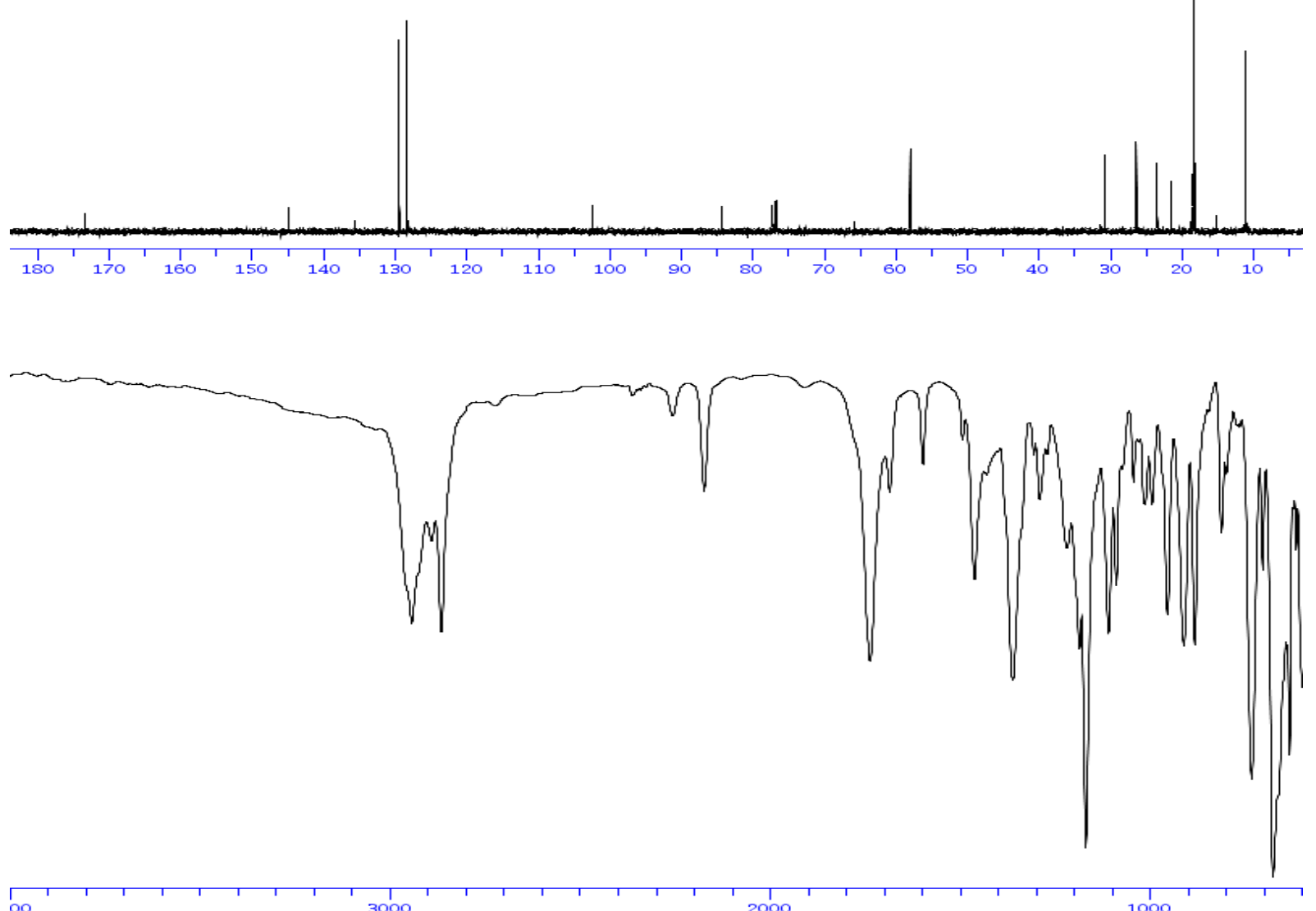
1-Tosyl-5-(3-(trimethylsilyl)prop-2-ynyl)pyrrolidin-2-one (4)

solvent: $\mathrm{CDCl} 3$

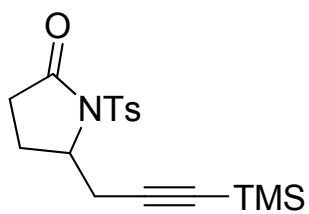

4

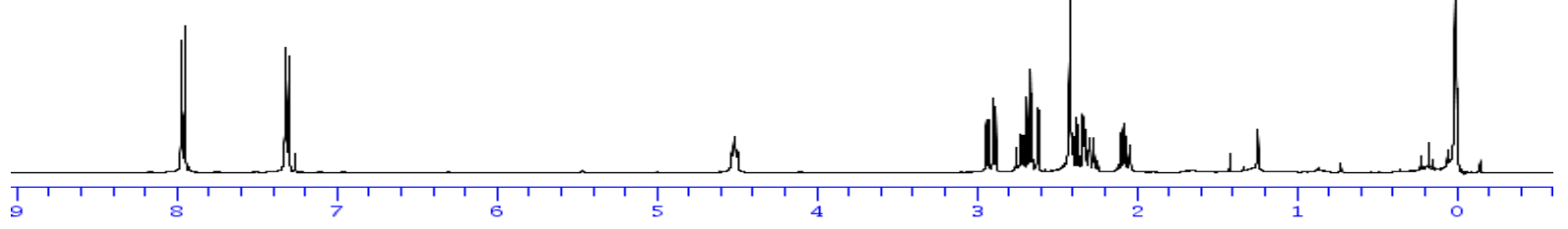

solvent: $\mathrm{CDCI}$
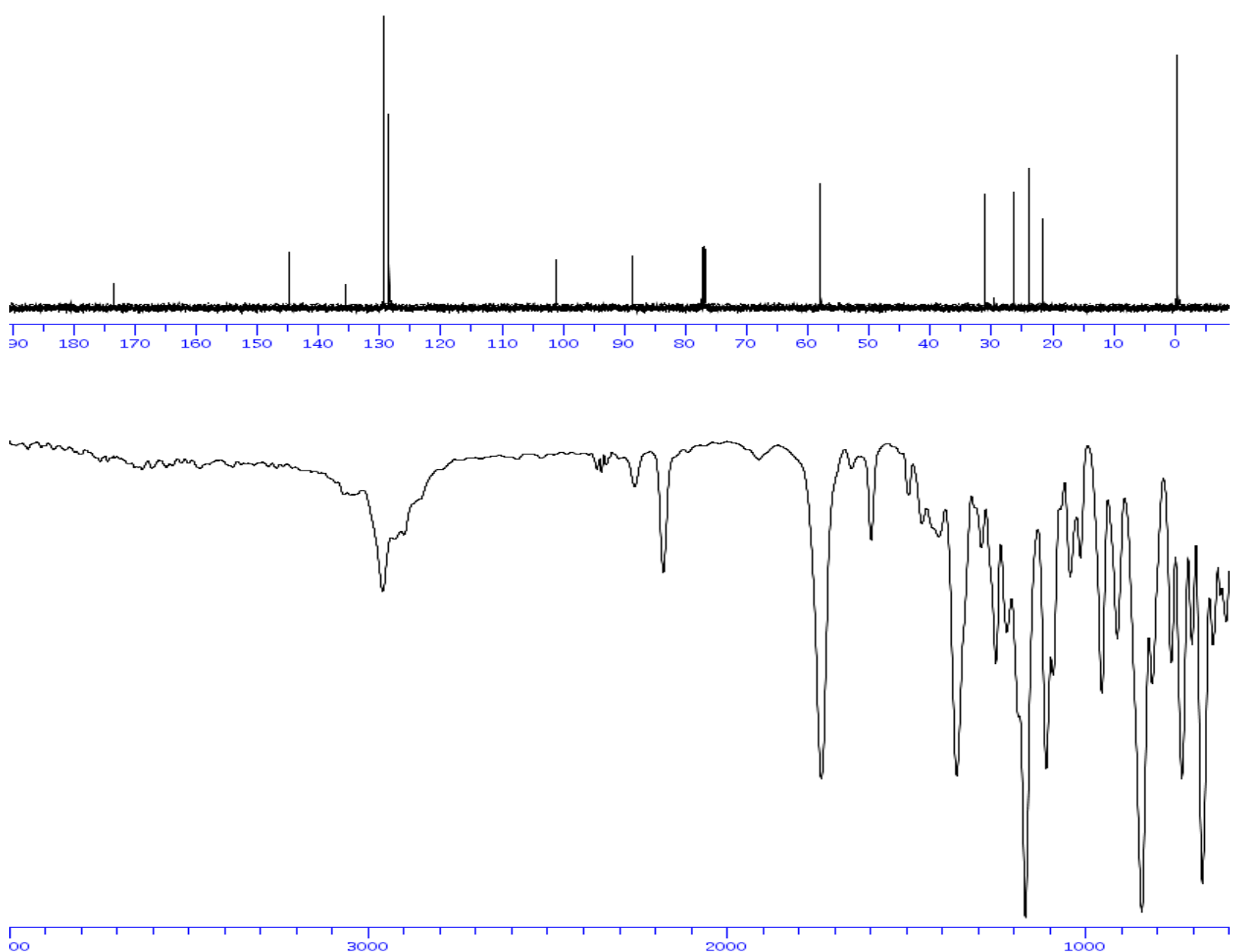
5-(3-Phenylprop-2-ynyl)-1-tosylpyrrolidin-2-one (5)

solvent: $\mathrm{CDCl} 3$

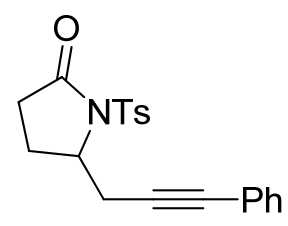

5

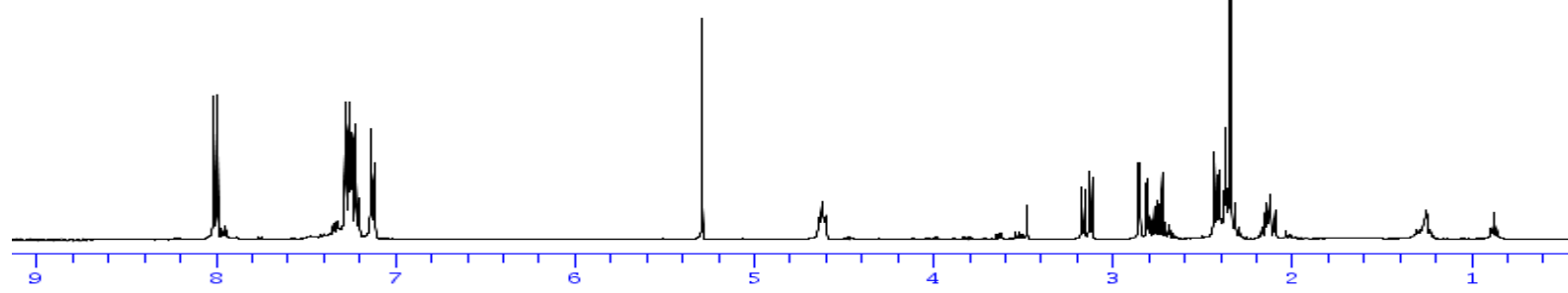

solvent: $\mathrm{CDCI}$

$100.61 \mathrm{MHz}$
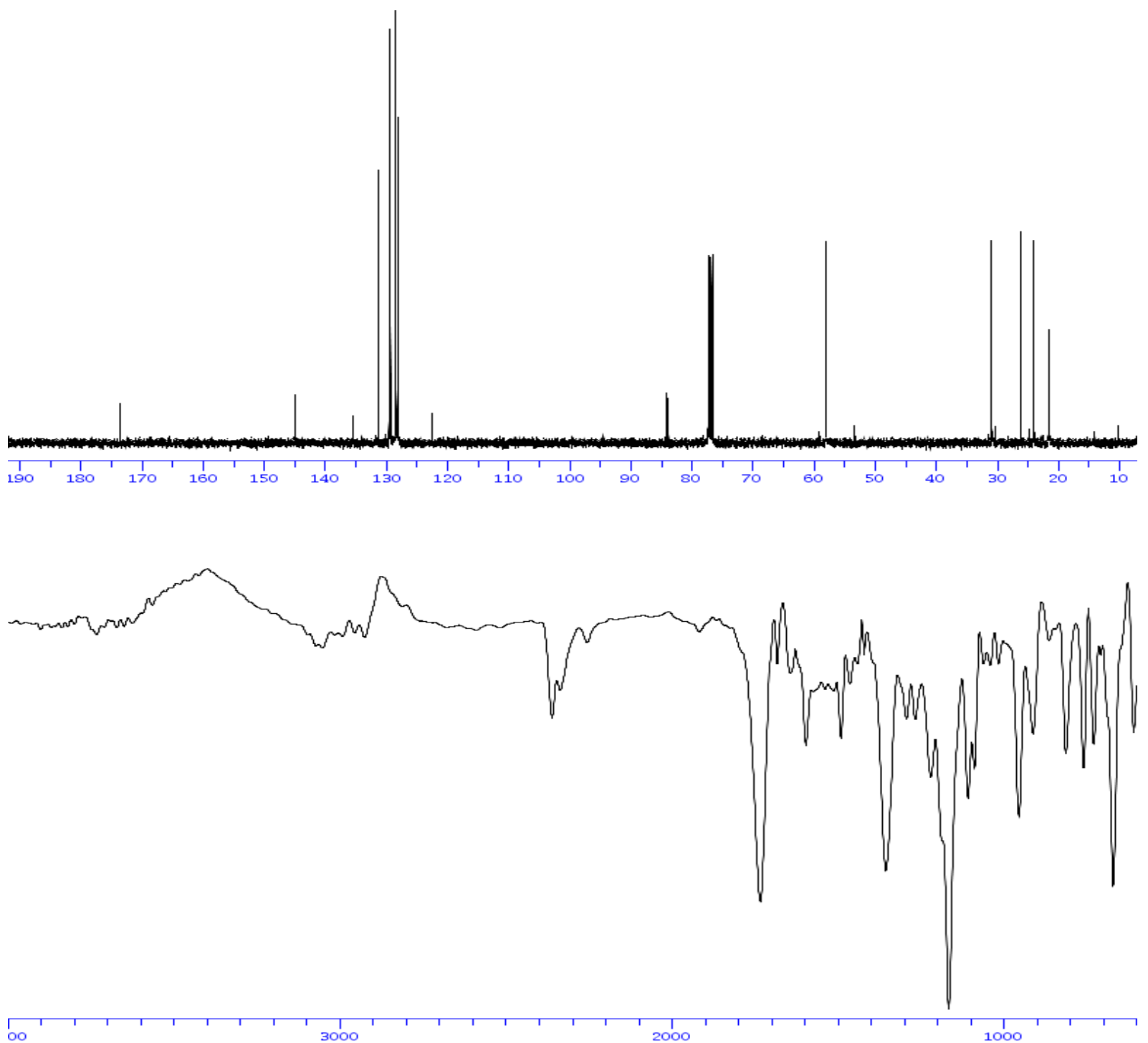
1-(4-Methoxyphenylsulfonyl)-5-(3-(triisopropylsilyl)prop-2-ynyl)pyrrolidin-2-one (3b)
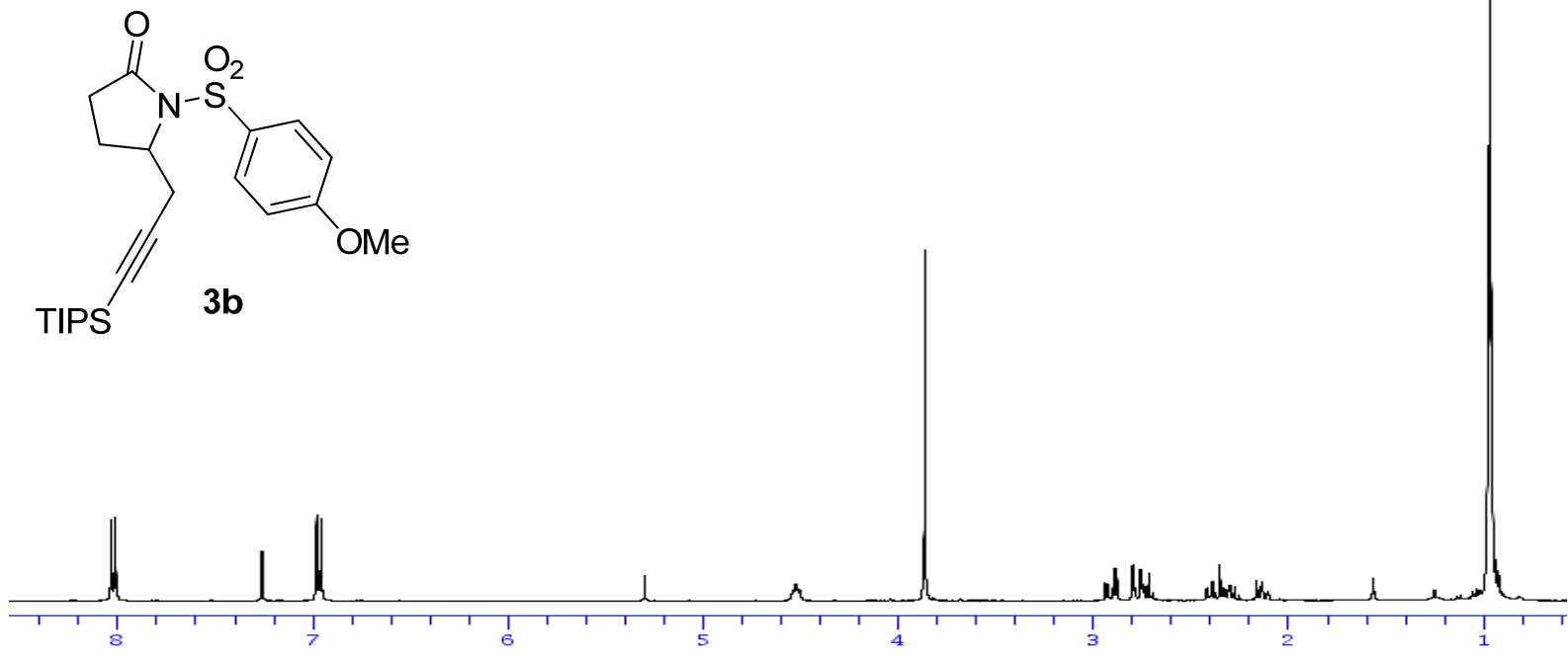

Solvent: $\mathrm{CDCl} 3$
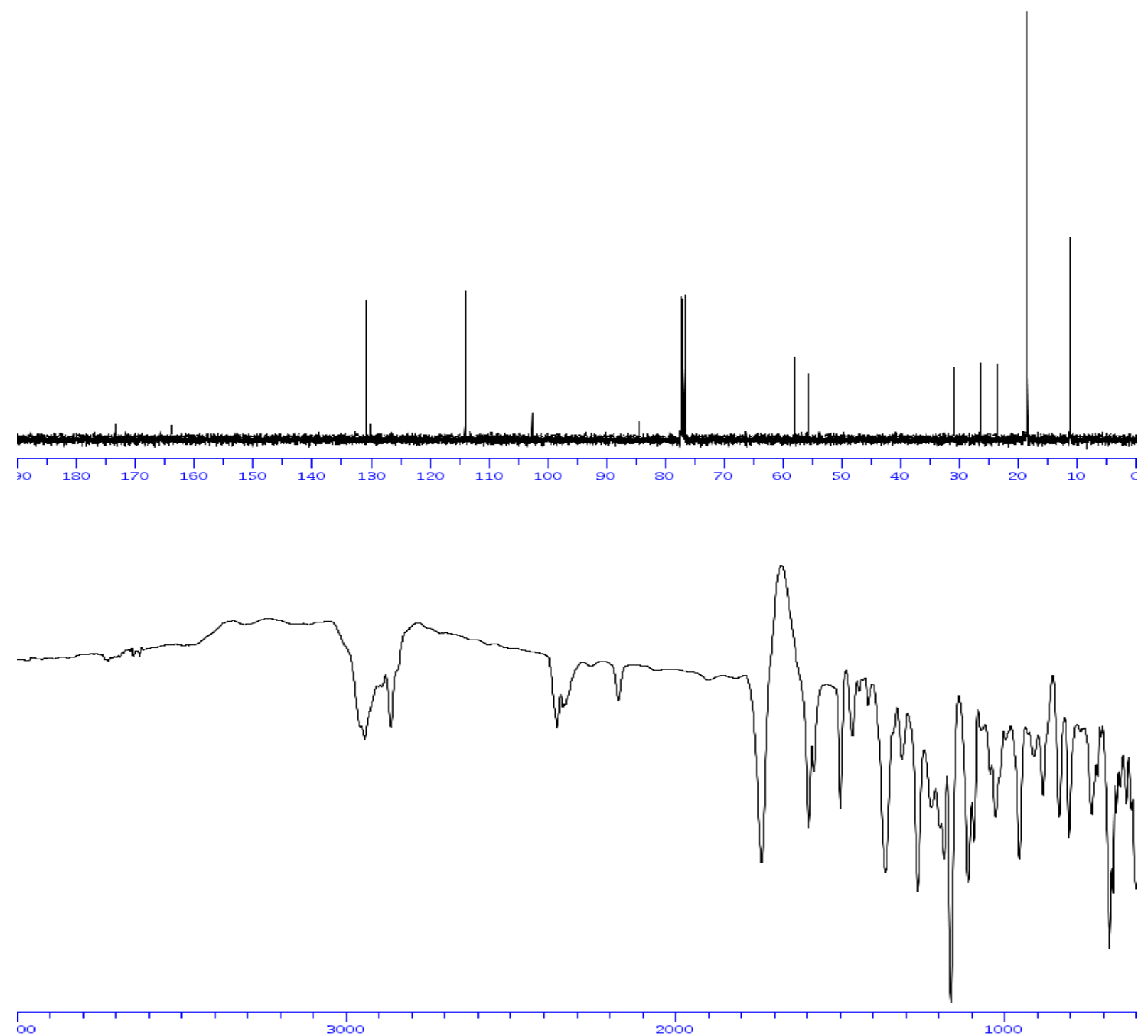
1-(4-Nitrophenylsulfonyl)-5-(3-(triisopropylsilyl)prop-2-nyl)pyrrolidin-one (3c)

solvent: $\mathrm{CDCI}$

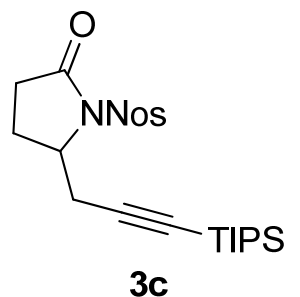

$3 c$

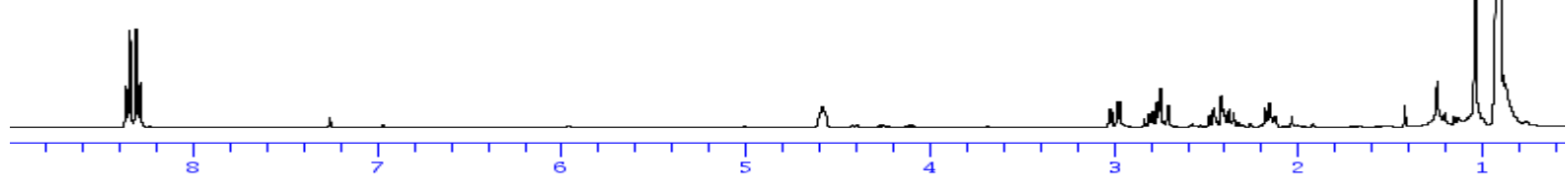

solvent: $\mathrm{CDCl} 3$
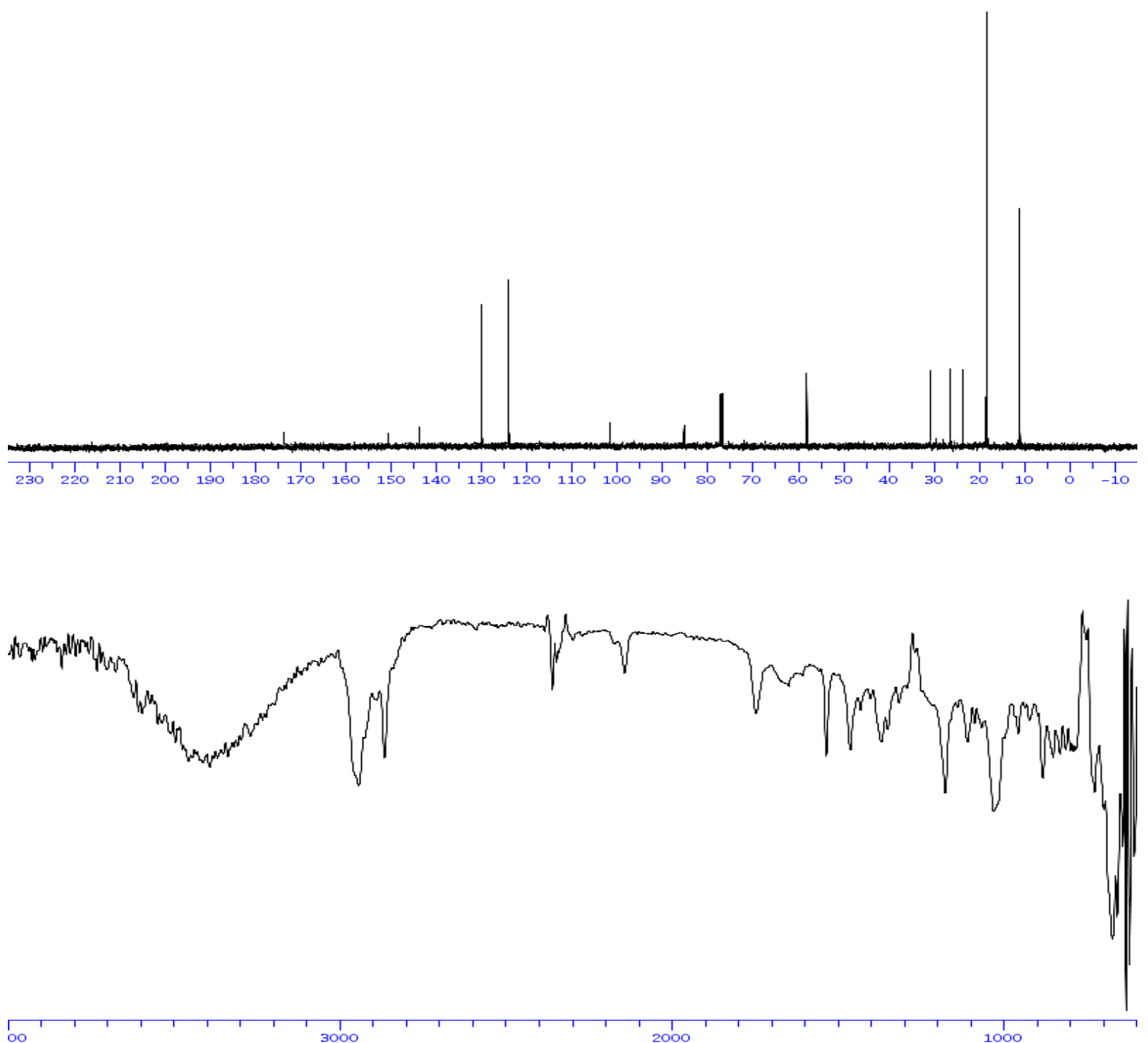

1000 
3,3-Dimethyl-1-tosyl-5-(3-(triisopropylsilyl)prop-2-ynyl)pyrrolidin-2-one (3d)

solvent: $\mathrm{CDCl} 3$

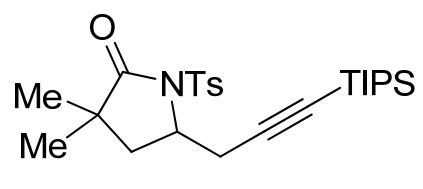

3d

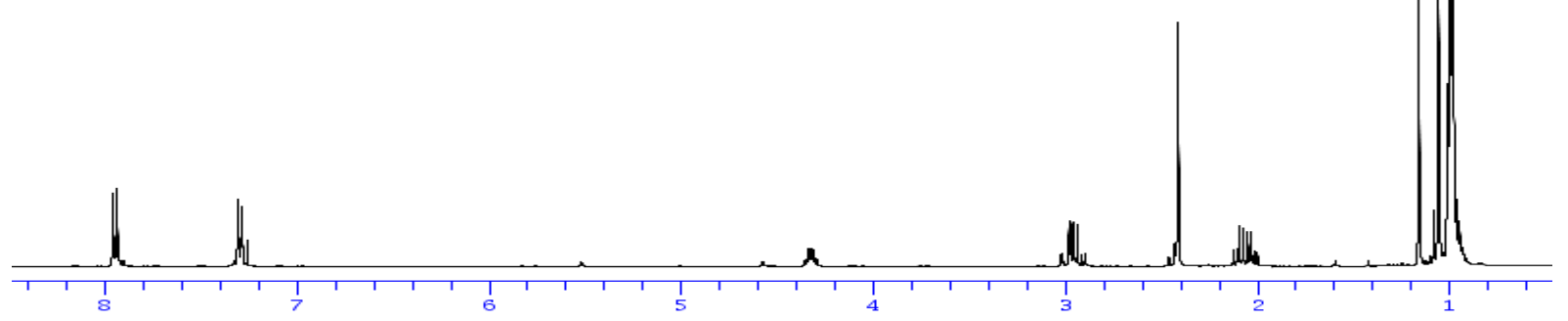

solvent: $\mathrm{CDCI}$

$100.61 \mathrm{MHz}$
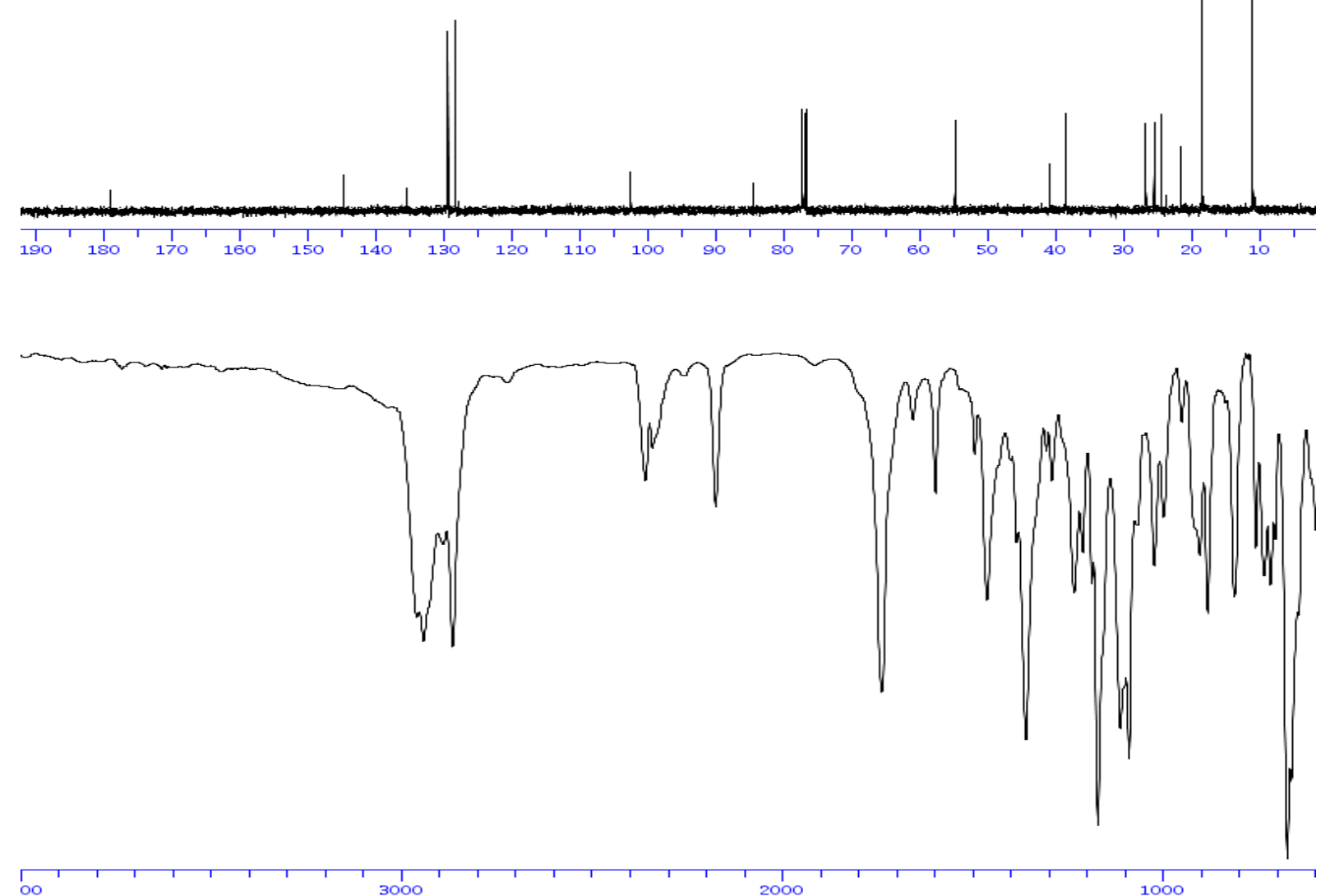
2-Tosyl-3-(3-(triisopropylsilyl)prop-2-ynyl)-2-azaspiro[4.5]decan-1-one (3e)

solvent: $\mathrm{CDCl} 3$

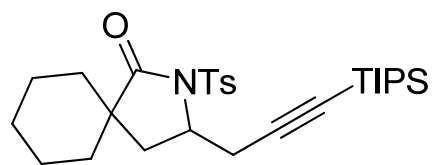

$3 e$

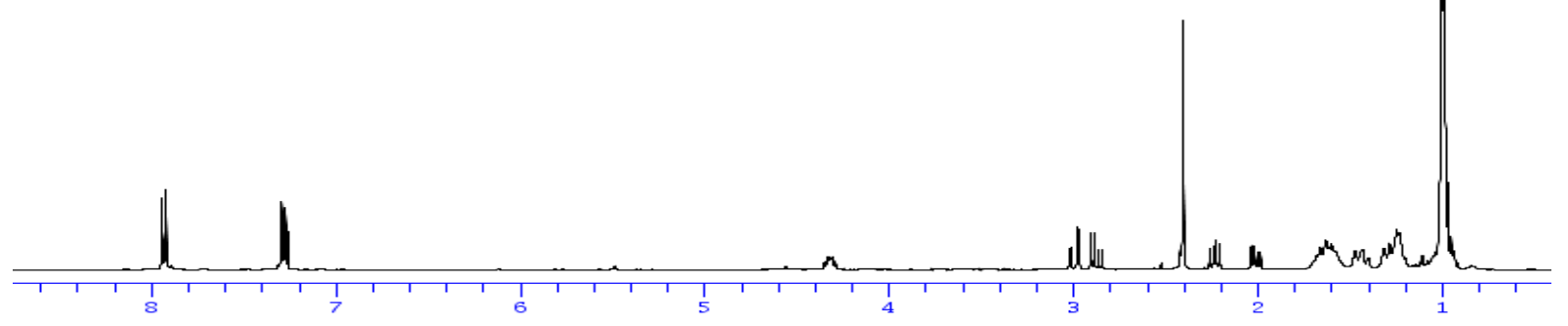

solvent: $\mathrm{CDCl} 3$

Frequencr $100.61 \mathrm{MHz}$
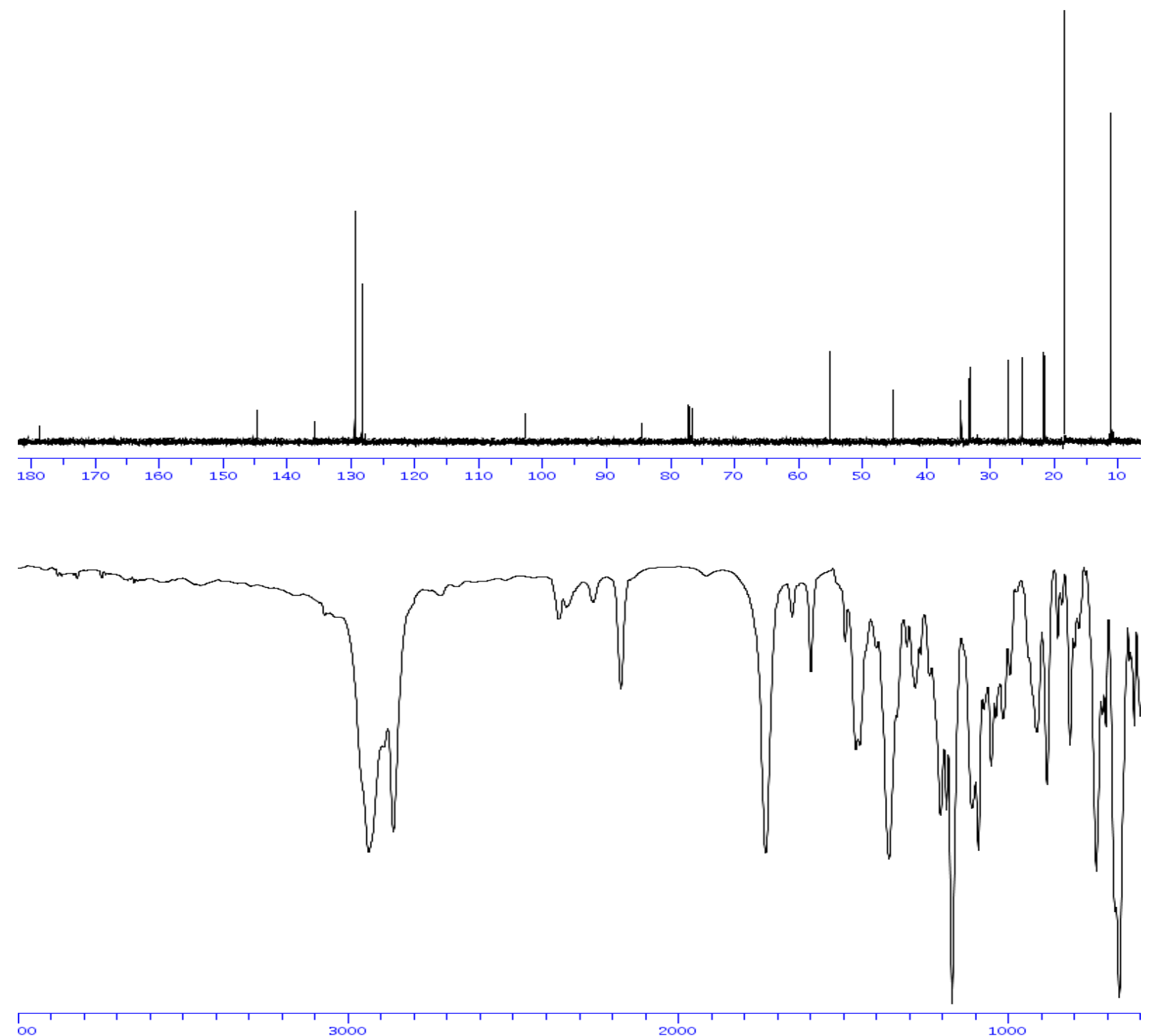
2-Tosyl-3-(3-(triisopropylsilyl)prop-2-ynyl)-2-azaspiro[4.4]nonan-1-one (3f)

solvent: $\mathrm{CDCl} 3$

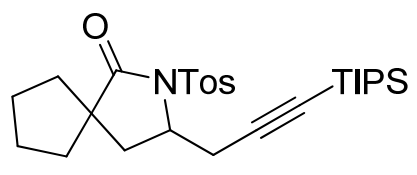

3f

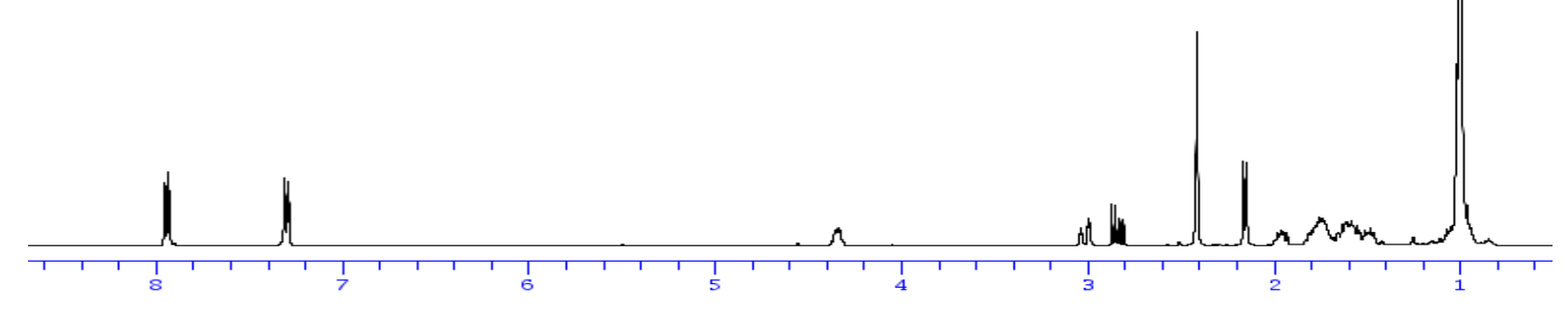

Solvent: $C D C I 3$
Frequency. $100.61 \mathrm{MHz}$
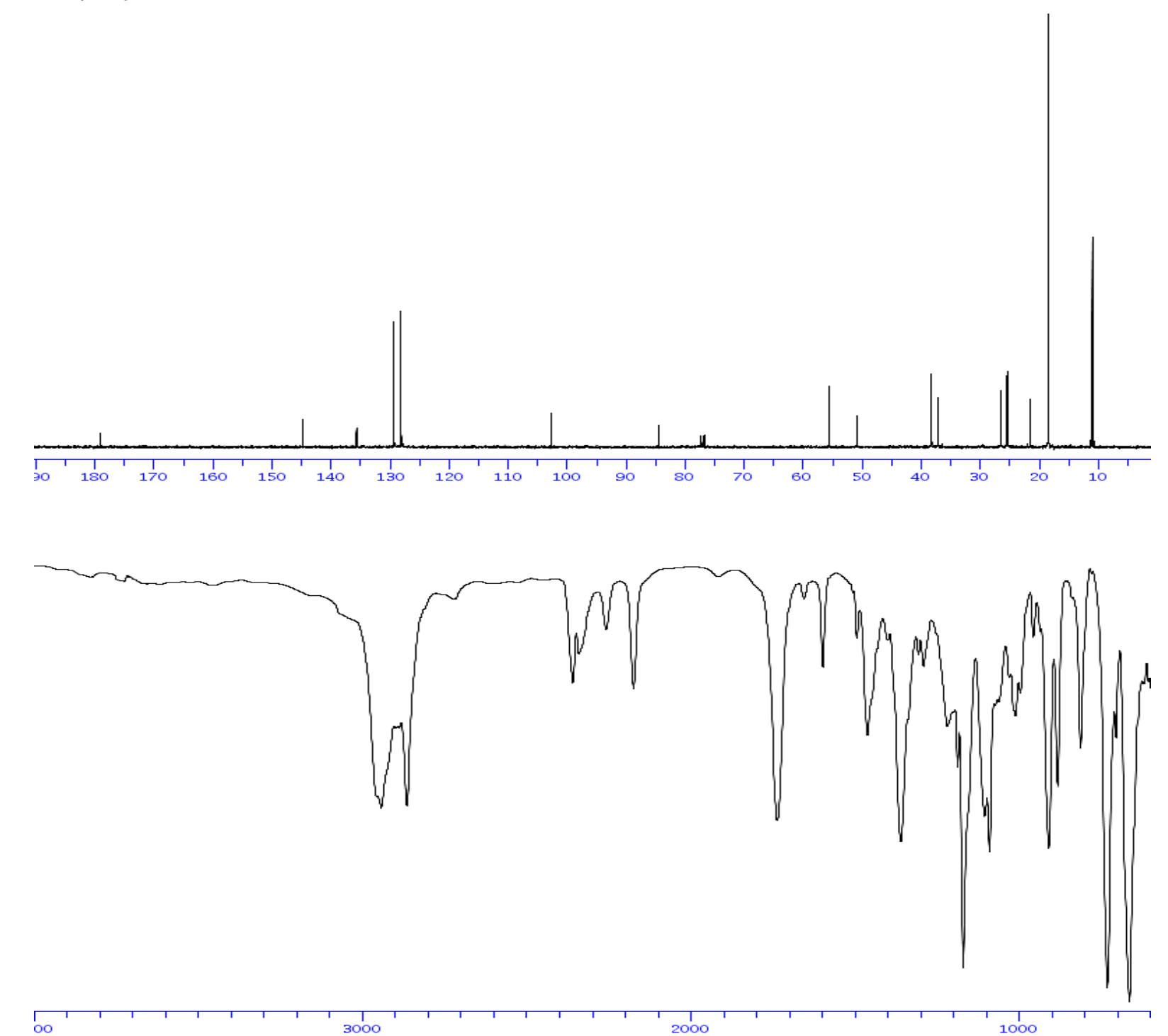
4-Phenyl-1-tosyl-5-(3-(triisopropylsilyl)prop-2-ynyl)pyrrolidin-2-one (3g)

solvent: $\mathrm{CDCl} 3$<smiles></smiles>

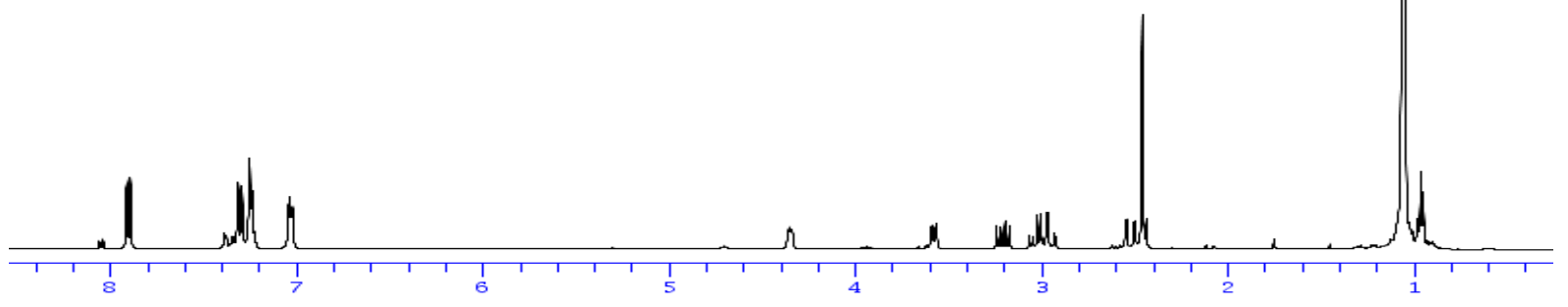

solvent: $C D C I 3$

STrequency $100.61 \mathrm{MHz}$
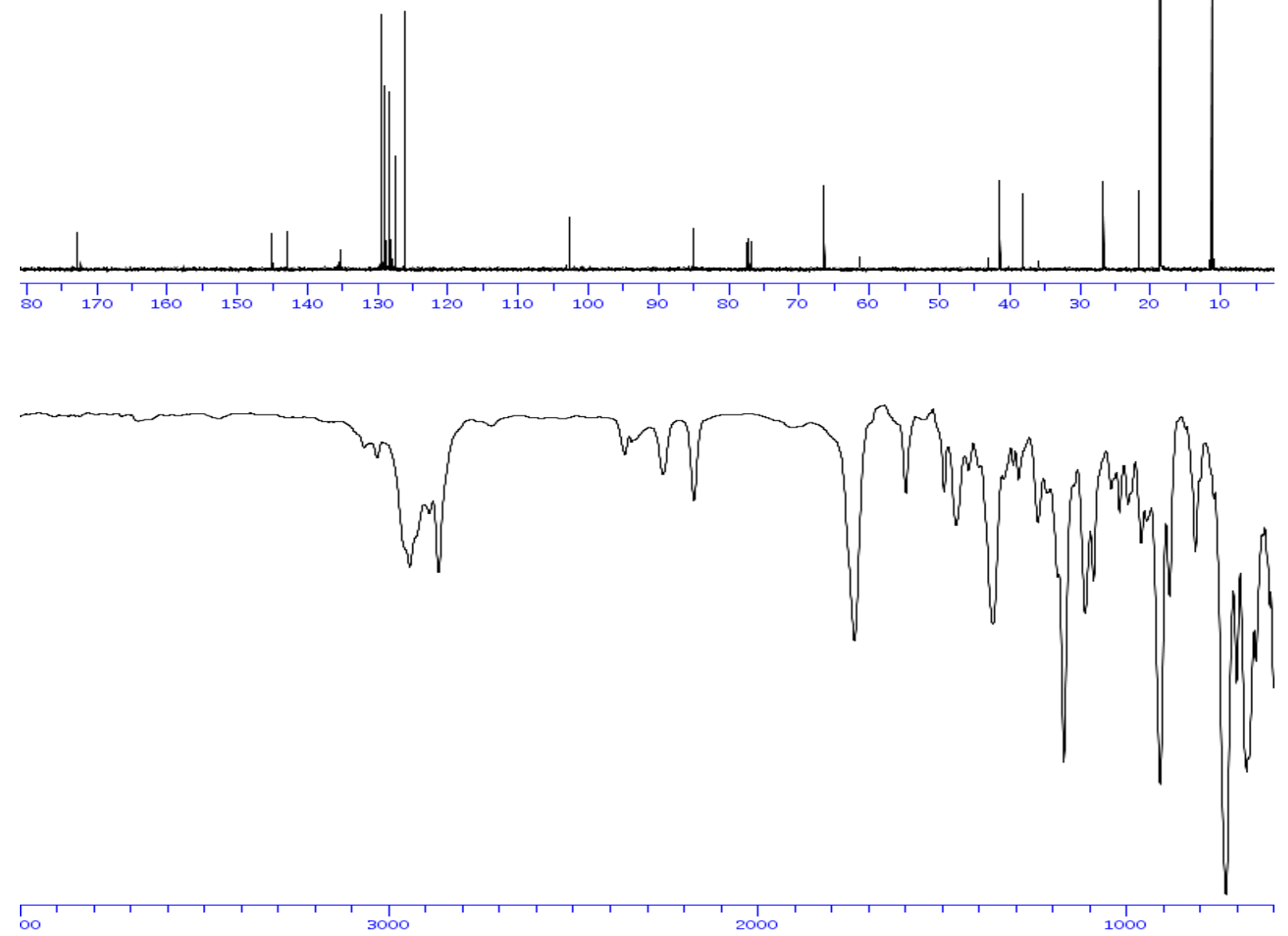
2-Tosyl-3-(3-(triisopropylsilyl)prop-2-ynyl)octahydro-1H-isoindol-1-one (3h)

solvent: $\mathrm{CDCl} 3$

Frequencr 400 . $13 \mathrm{MHz}$

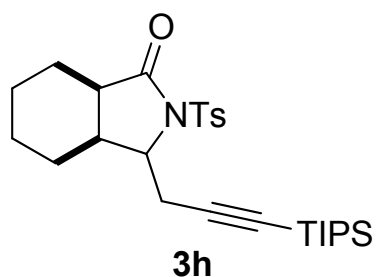

$3 h$

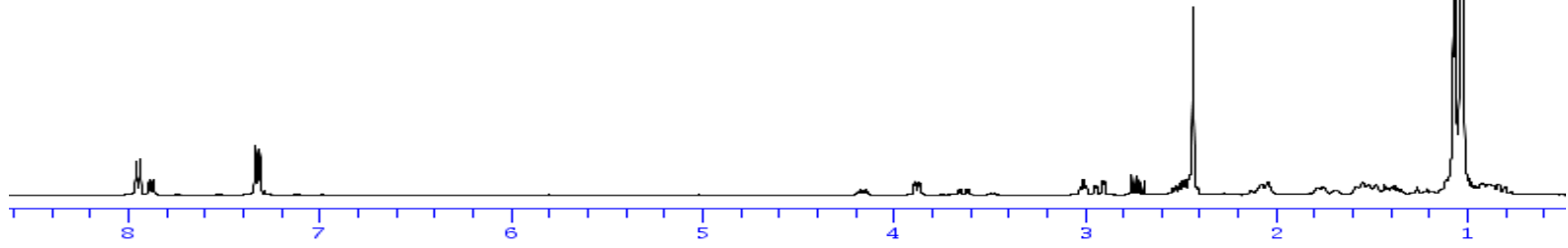

solvent: $\mathrm{CDCI} 3$
Frequency $100.61 \mathrm{MHz}$
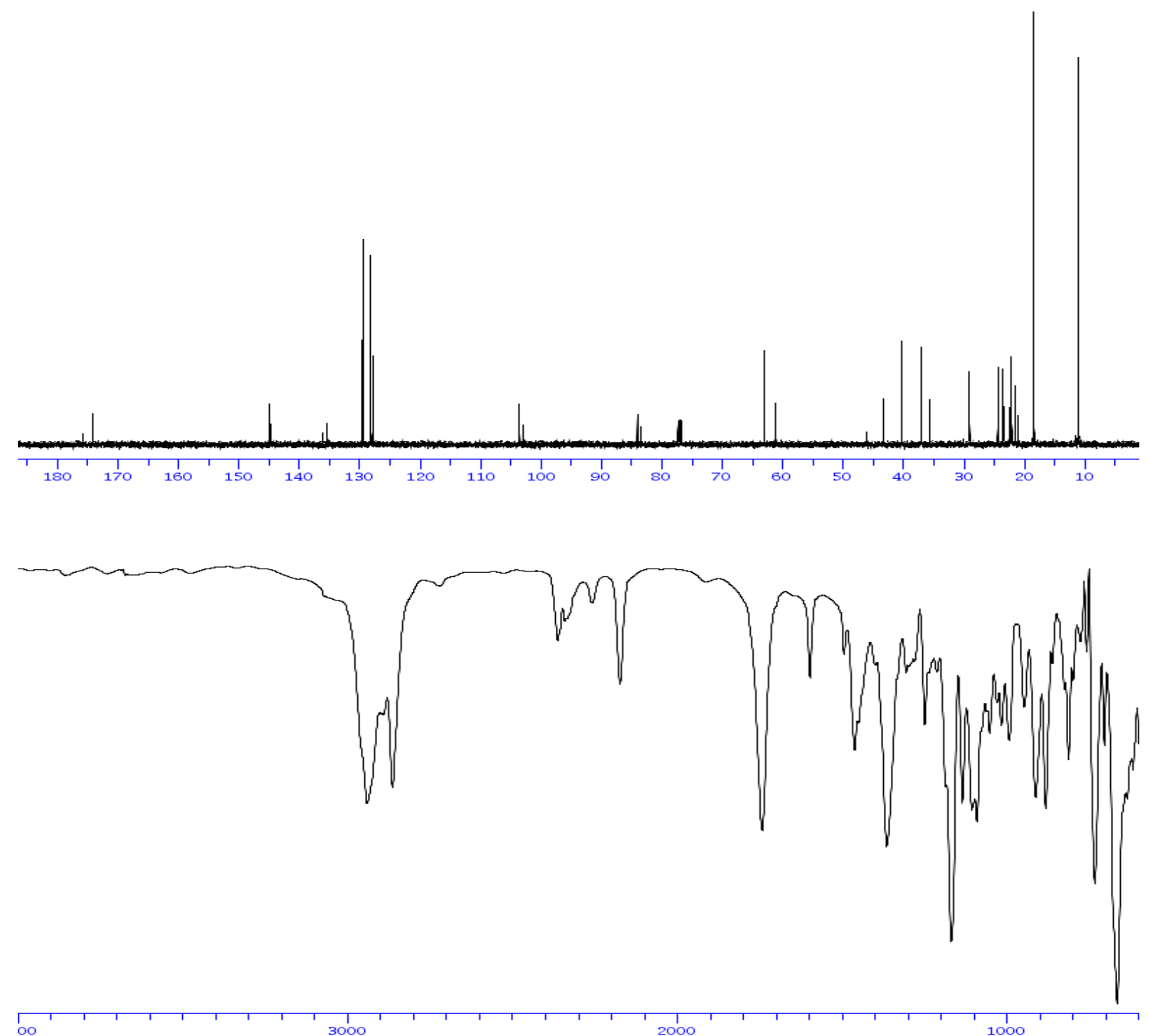

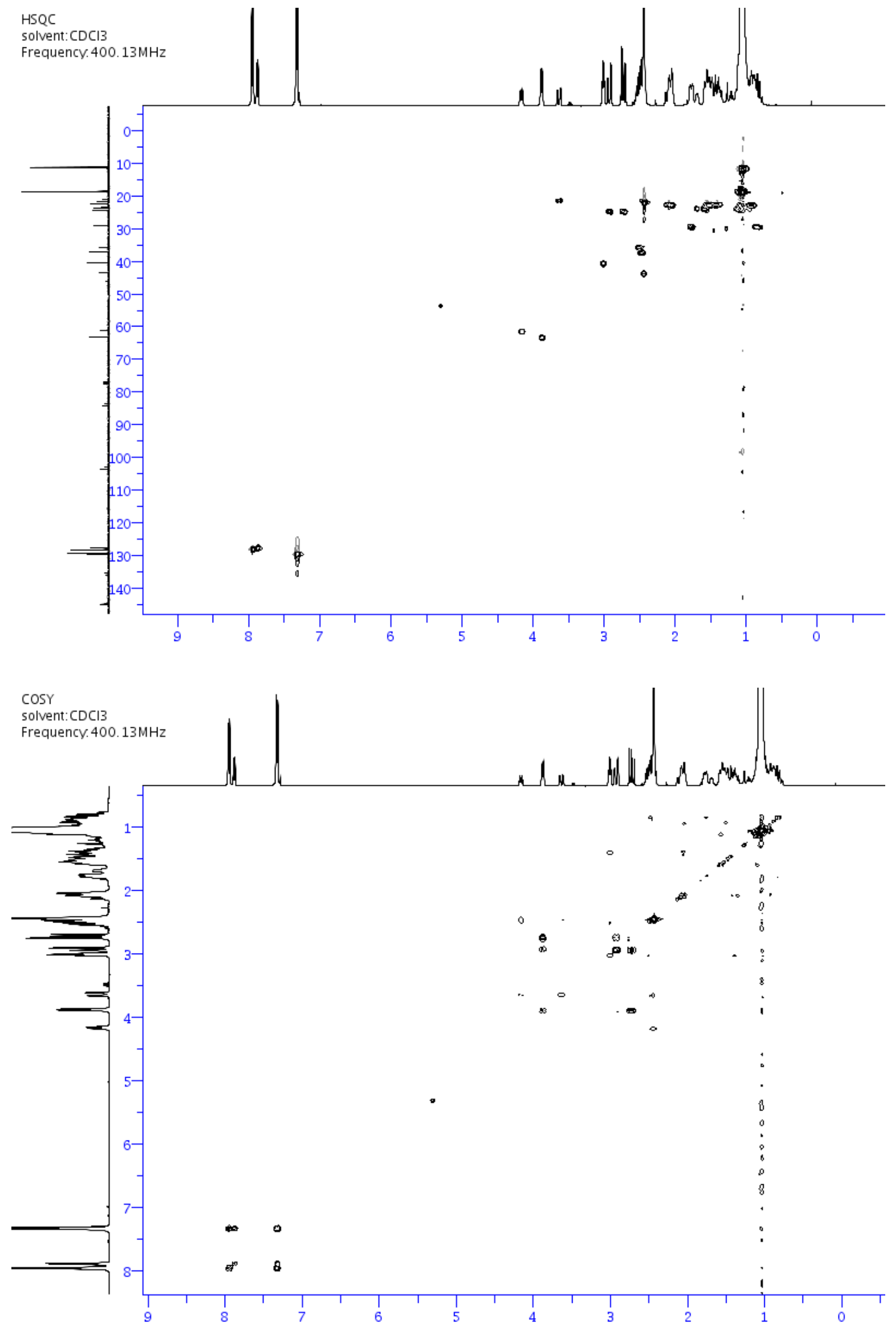
1-Tosyl-6-(3-(triisopropylsilyl)prop-2-ynyl)piperidin-2-one (3i)

solvent: $\mathrm{CDCl} 3$

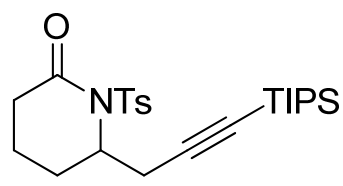

3i

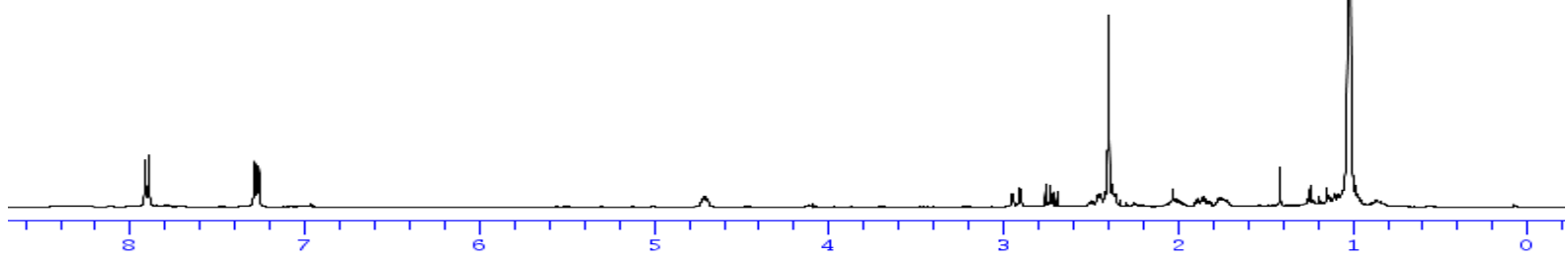

Solvent: $\mathrm{CDCI} 3$
Frequency $100.61 \mathrm{MHz}$
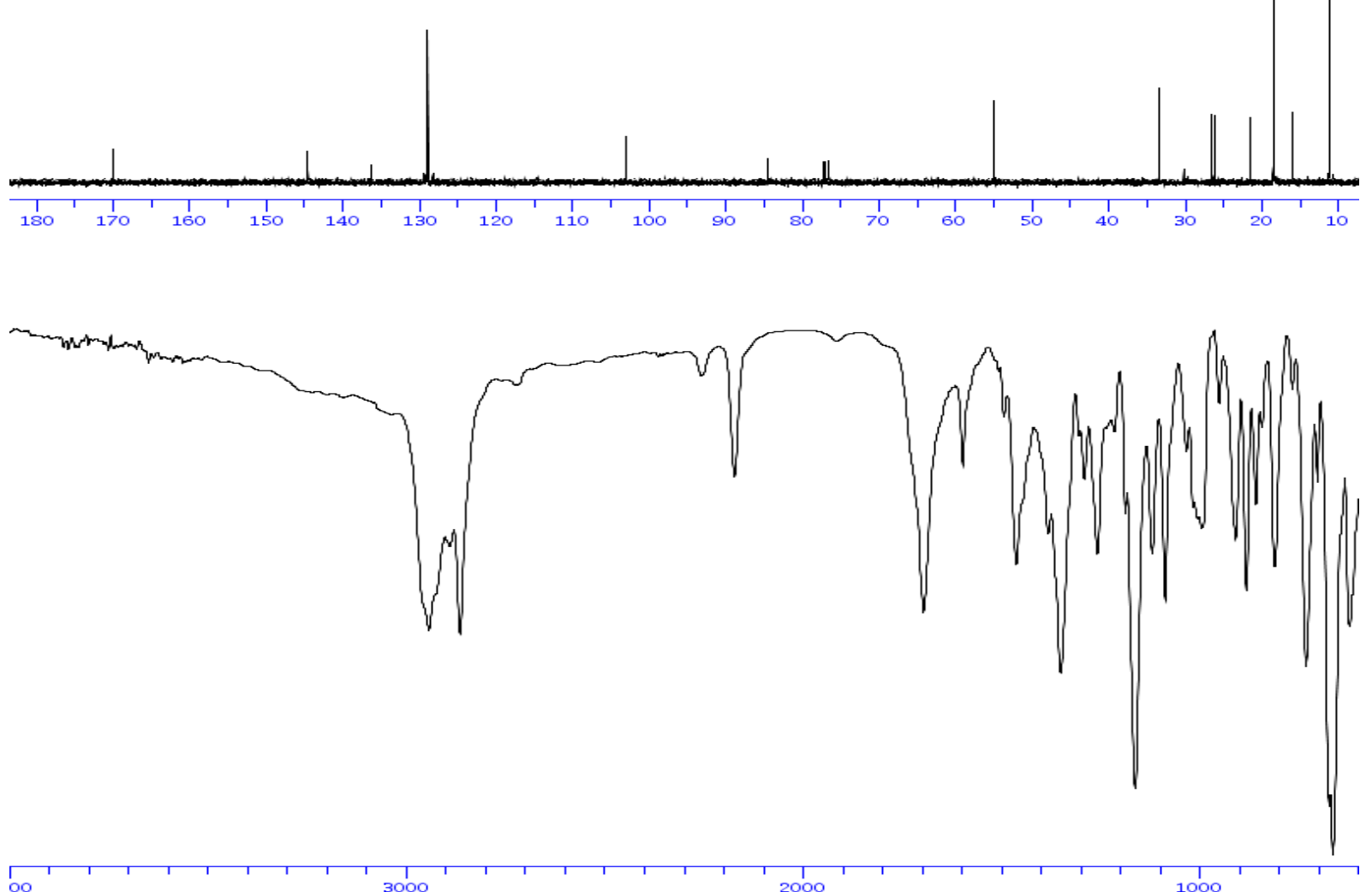
2-Tosyl-3-(3-(triisopropylsilyl)prop-2-ynyl)-3,4-dihydroisoquinolin-1(2H)-one (3j)

solvent: $C D C I 3$<smiles>O=C1c2ccccc2CC(CC#C[In])[NH+]1S</smiles>

3j

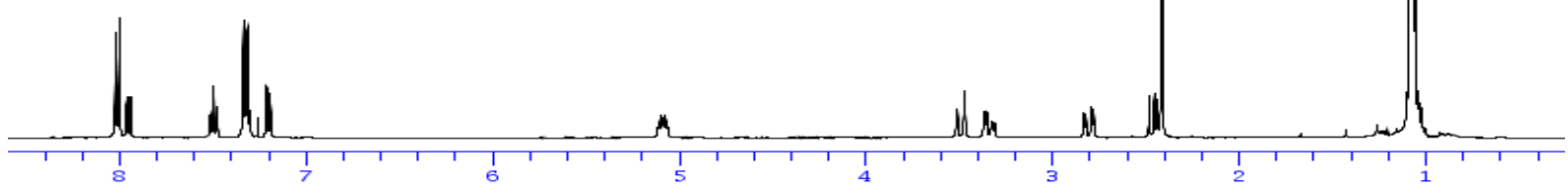

solvent: $\mathrm{CDCI}$

$100.61 \mathrm{MHz}$
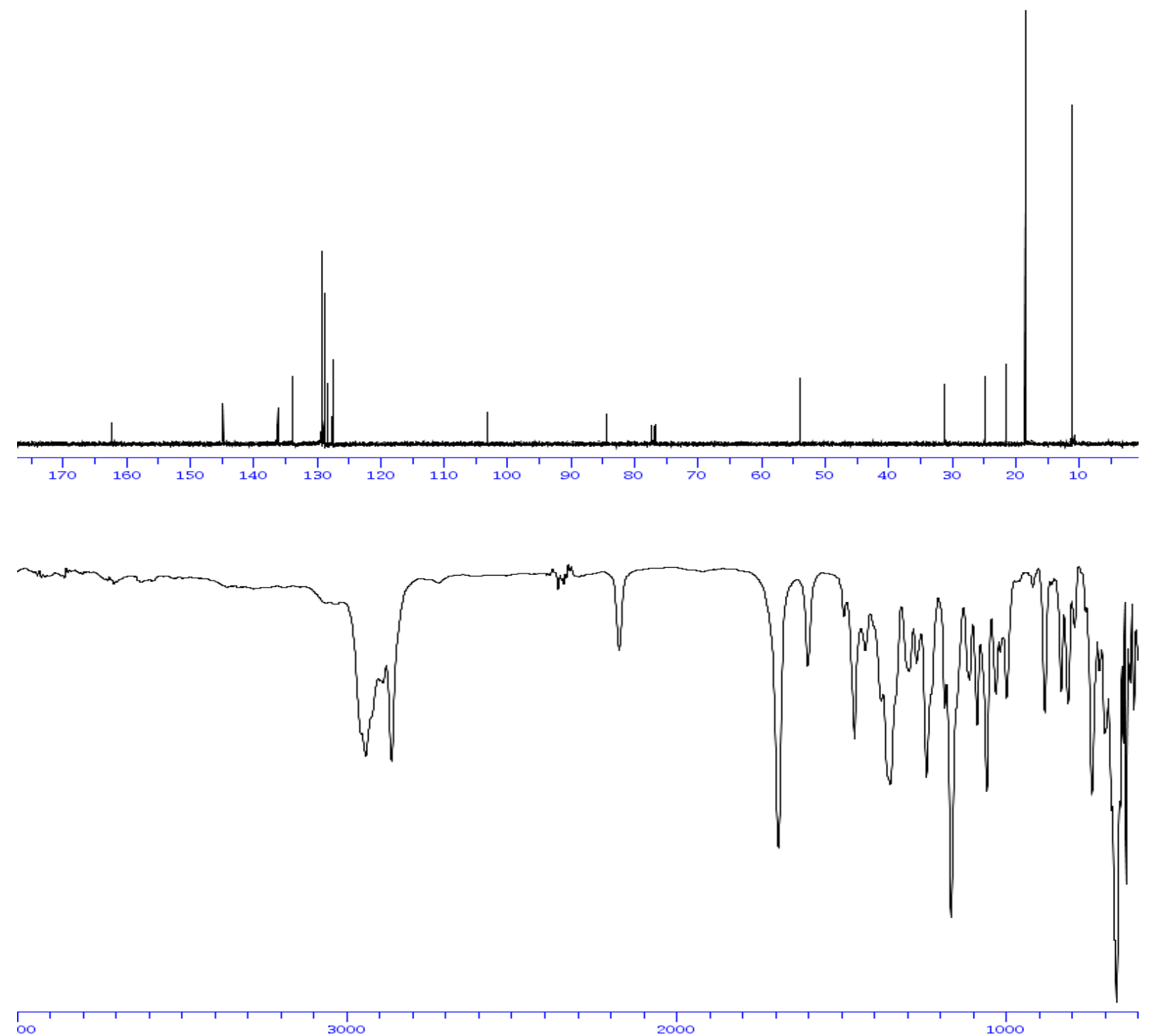
2-Tosyl-3-(3-(triisopropylsilyl)prop-2-ynyl)-3,4-dihydropyrrolo[1,2-a]pyrazin-1(2H)-one (3k)

solvent: $\mathrm{CDCI} 3 \mathrm{M}$<smiles>O=C1[NH2+]C(CC#C[In])Cn2cccc21</smiles>

$3 \mathbf{k}$

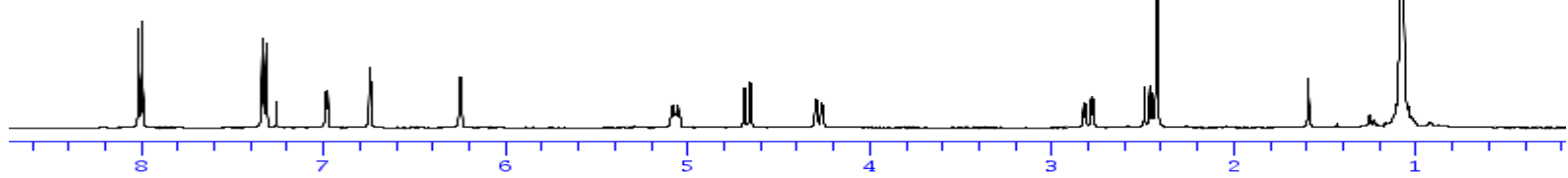

solvent: $\mathrm{CDCl} 3$

$100.61 \mathrm{MHz}$
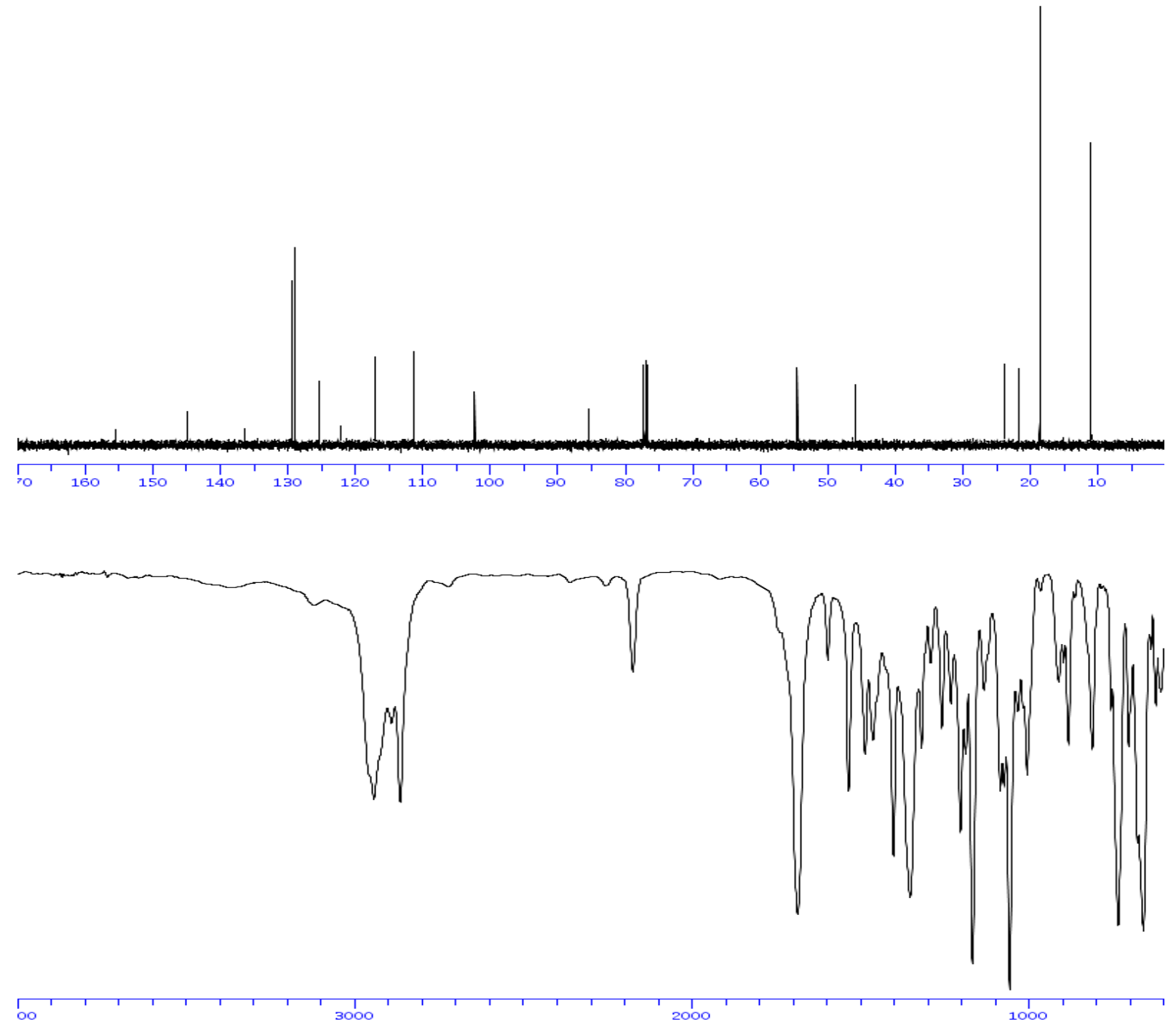
2-Tosyl-3-(3-(triisopropylsilyl)prop-2-ynyl)-3,4-dihydropyrazino[1,2-a]indol-1(2H)-one (3I)

solvent: $\mathrm{CDCI} 3$

$13 \mathrm{MHz}$<smiles>O=C1c2cc3ccccc3n2CC(CC#C[In])[NH+]1S</smiles>

3

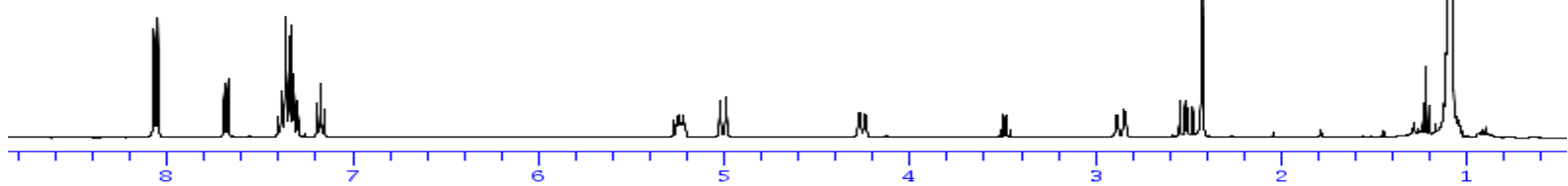

solvent: $\mathrm{CDCl} 3$

. $100.61 \mathrm{MHz}$

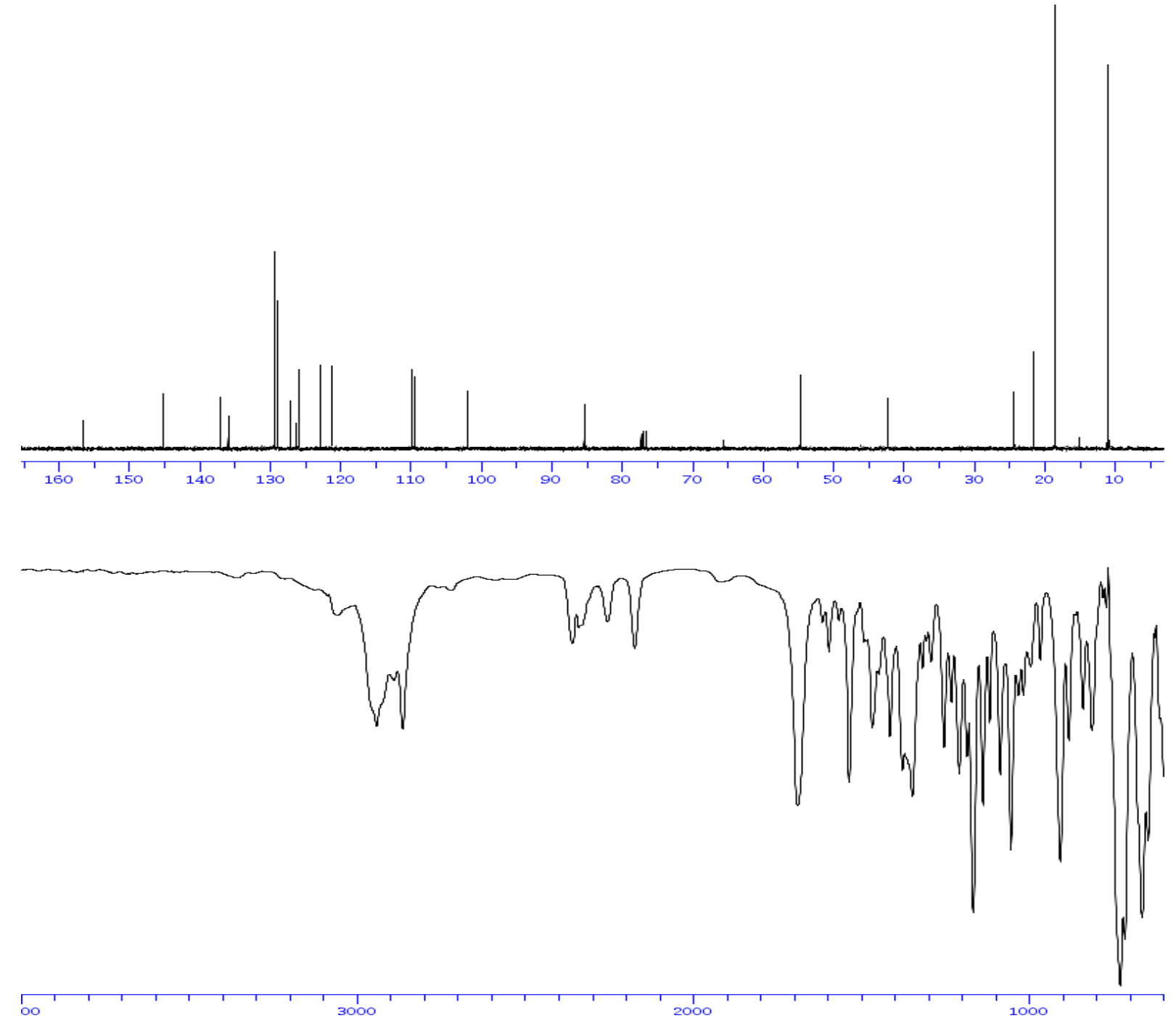


5-methyl-1-(4-nitrophenylsulfonyl)-5-(3-(triisopropylsilyl)prop-2-ynyl)pyrrolidin-2-one (3m)

solvent: $\mathrm{CDCl} 3$
Frequency, $400.13 \mathrm{MHz}$

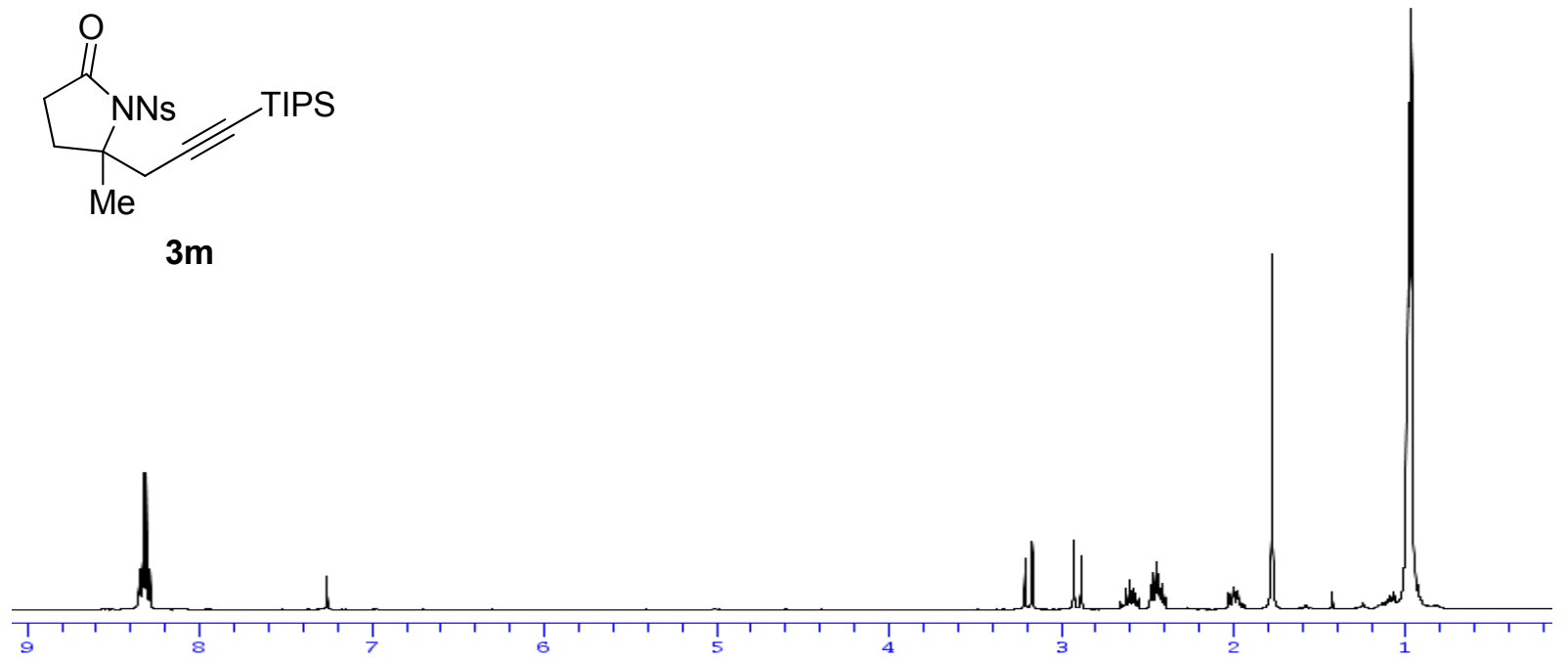

solvent: $\mathrm{CDCl} 3$

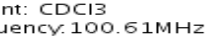


3-Tosyl-4-(3-(triisopropylsilyl)prop-2-ynyl)oxazolidin-2-one (7a)

solvent: $\mathrm{CDCI} 3$

$400.13 \mathrm{MHz}$

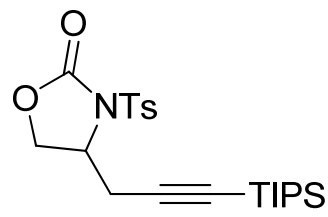

$7 a$

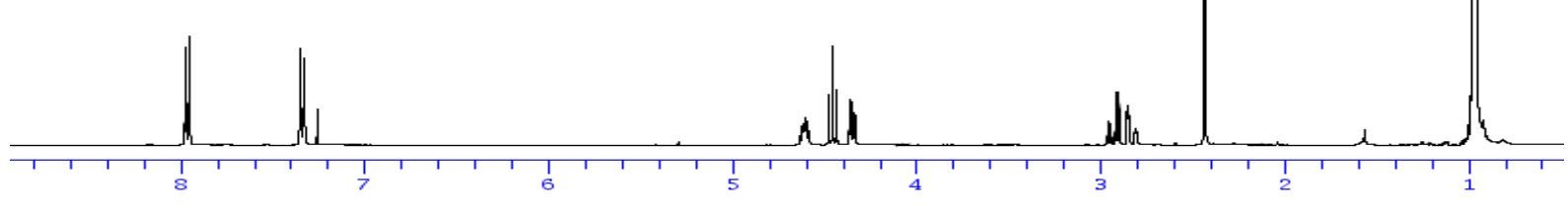

solvent: $\mathrm{CDCl} 3$
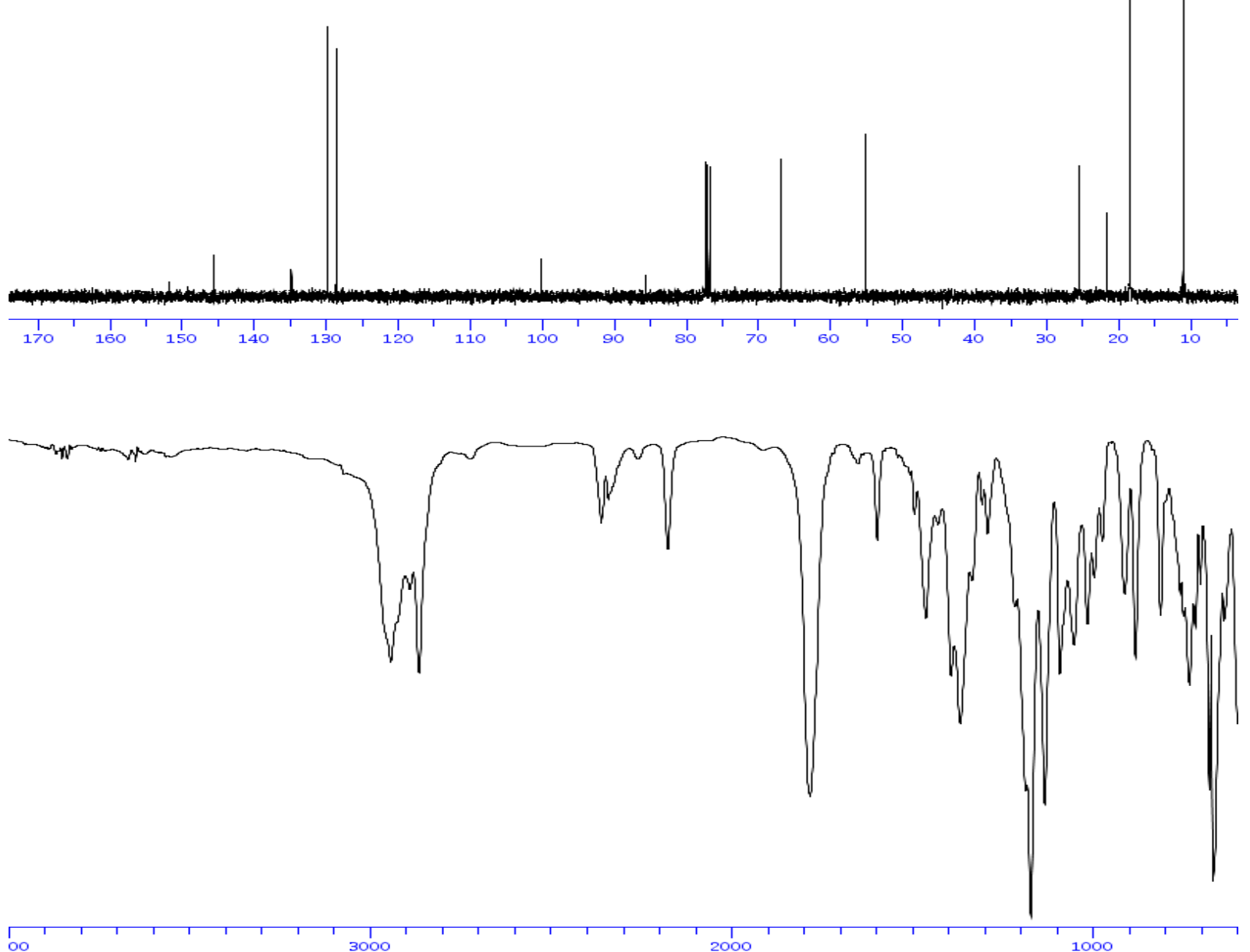
5-Methyl-3-tosyl-4-(3-(triisopropylsilyl)prop-2-ynyl)oxazolidin-2-one

(7b, major diastereoisomer)

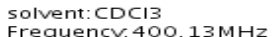<smiles>CC1OC(=O)[NH2+][C@@H]1CC#C[In]</smiles>

7b, Major diastereoisomer

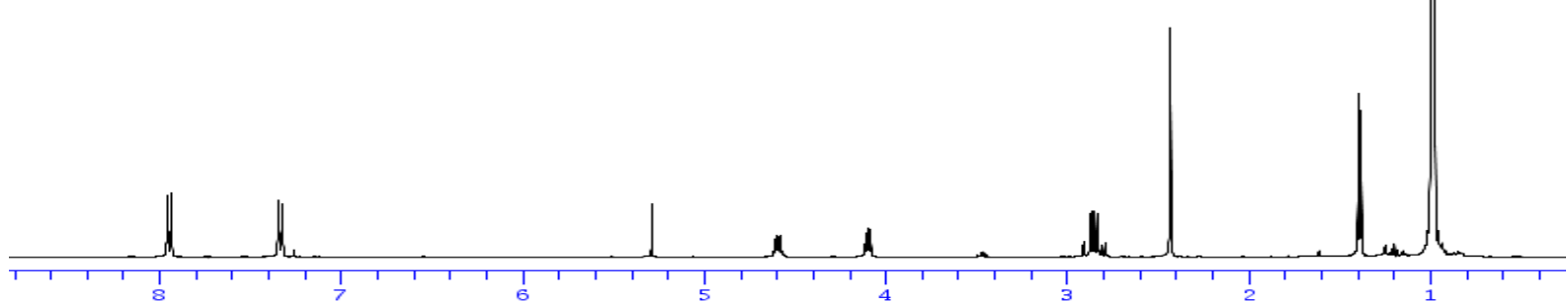

solvent: $C D C l 3$
Frequency. $100.61 \mathrm{MHz}$
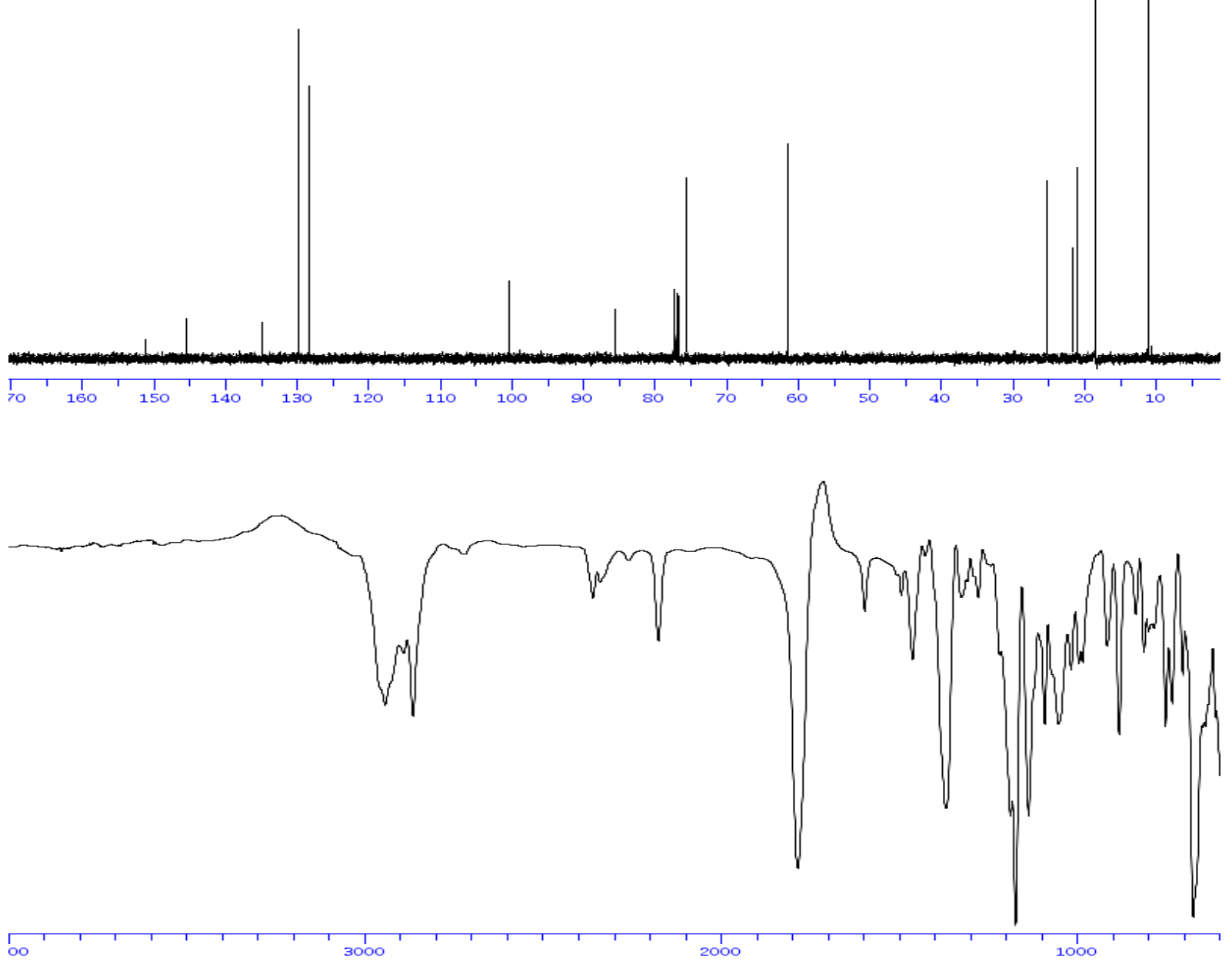


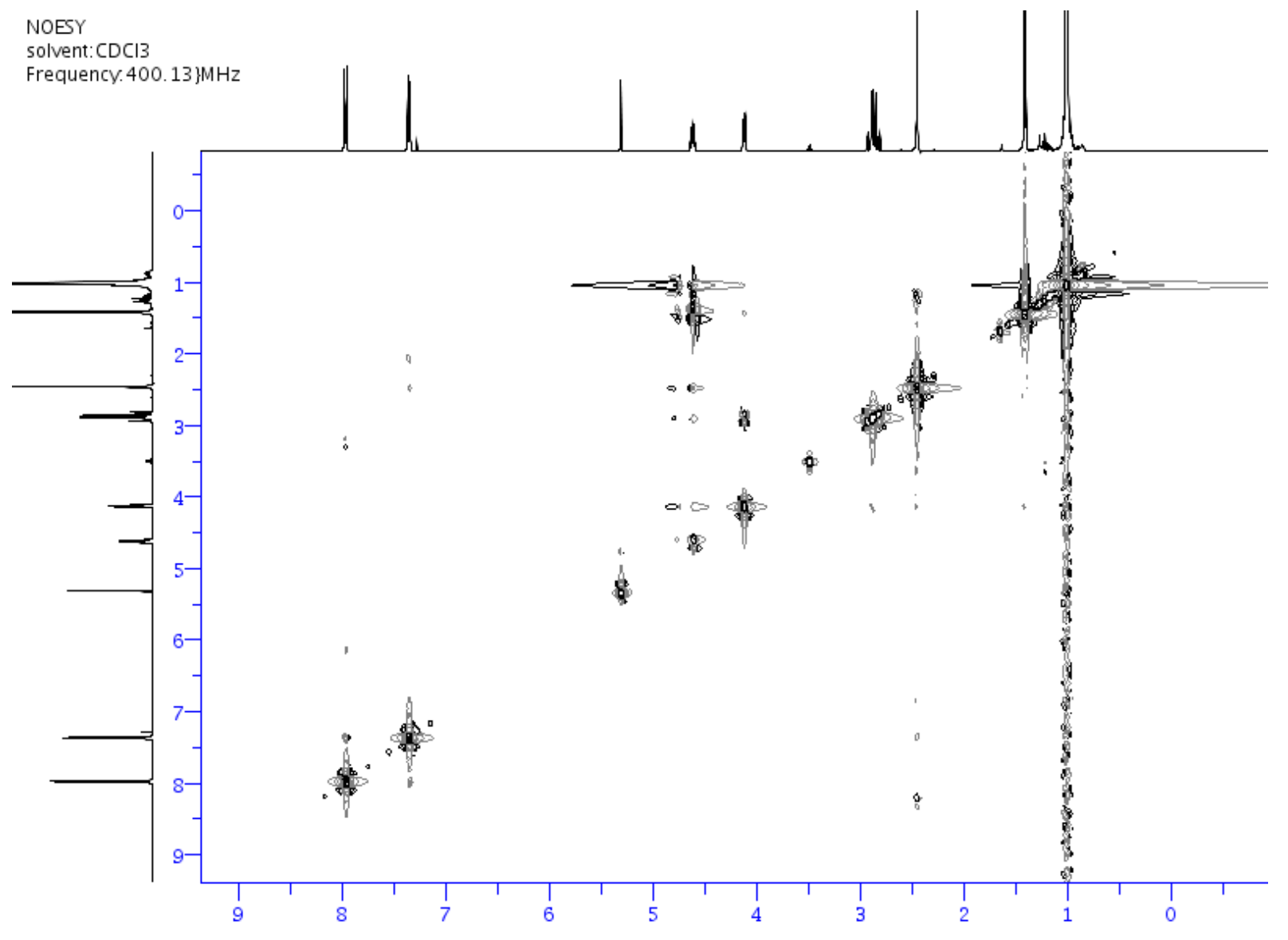


5-Methyl-3-tosyl-4-(3-(triisopropylsilyl)prop-2-ynyl)oxazolidin-2-one

(7b, minor diastereoisomer)

Solvent: $\mathrm{CDCI} 3$<smiles>CC1OC(=O)[NH2+]C1CC#C[In-]</smiles>

7b, Minor diastereoisomer

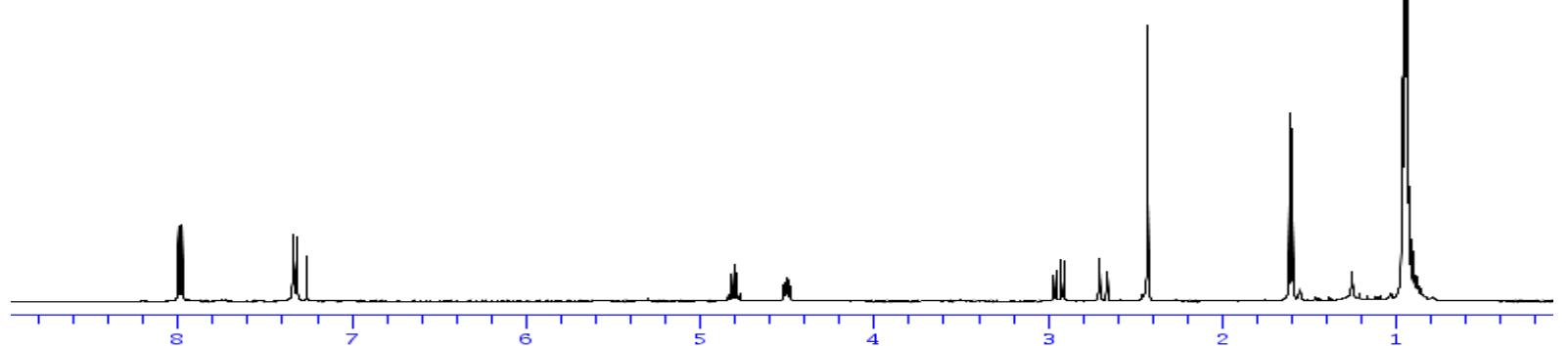

solvent: $\mathrm{CDCI}$
Frequency. $100.61 \mathrm{MHz}$
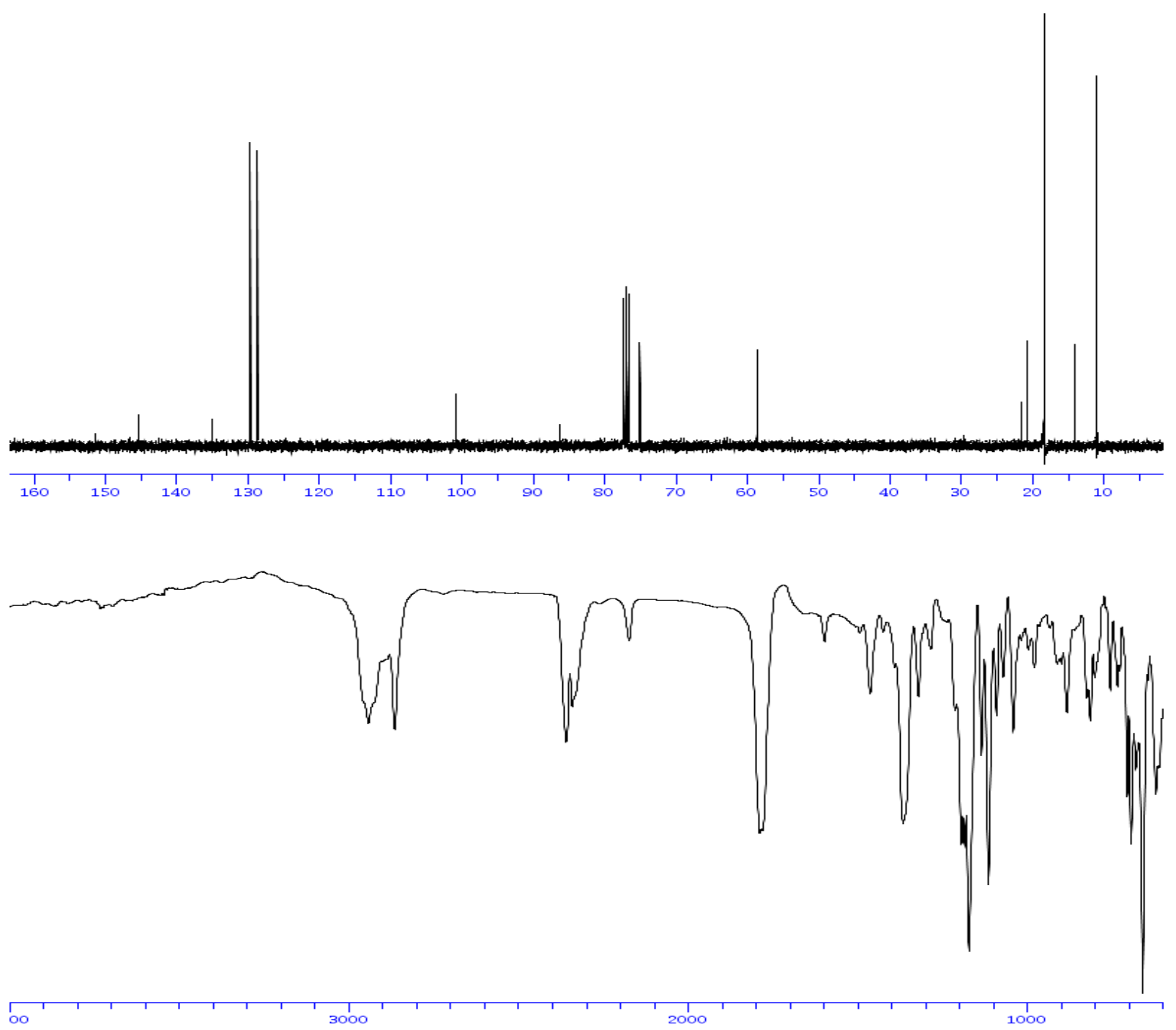
5-Cyclohexyl-3-tosyl-4-(3-(triisopropylsilyl)prop-2-ynyl)oxazolidin-2-one (7c， major diastereoisomer)

solvent: $C D C I 3$
Frequency, $400.13 \mathrm{MHz}$

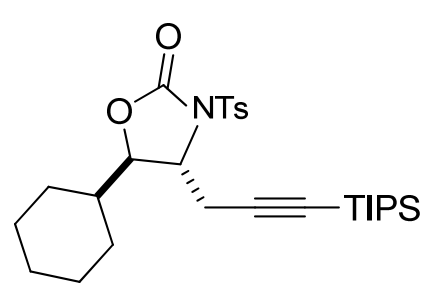

7c, Major diastereoisomer

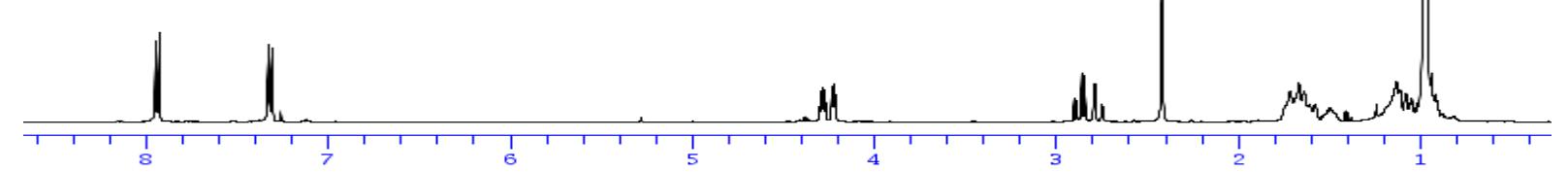

solvent: $\mathrm{CDCl}$

Frequency. $100.61 \mathrm{MHz}$
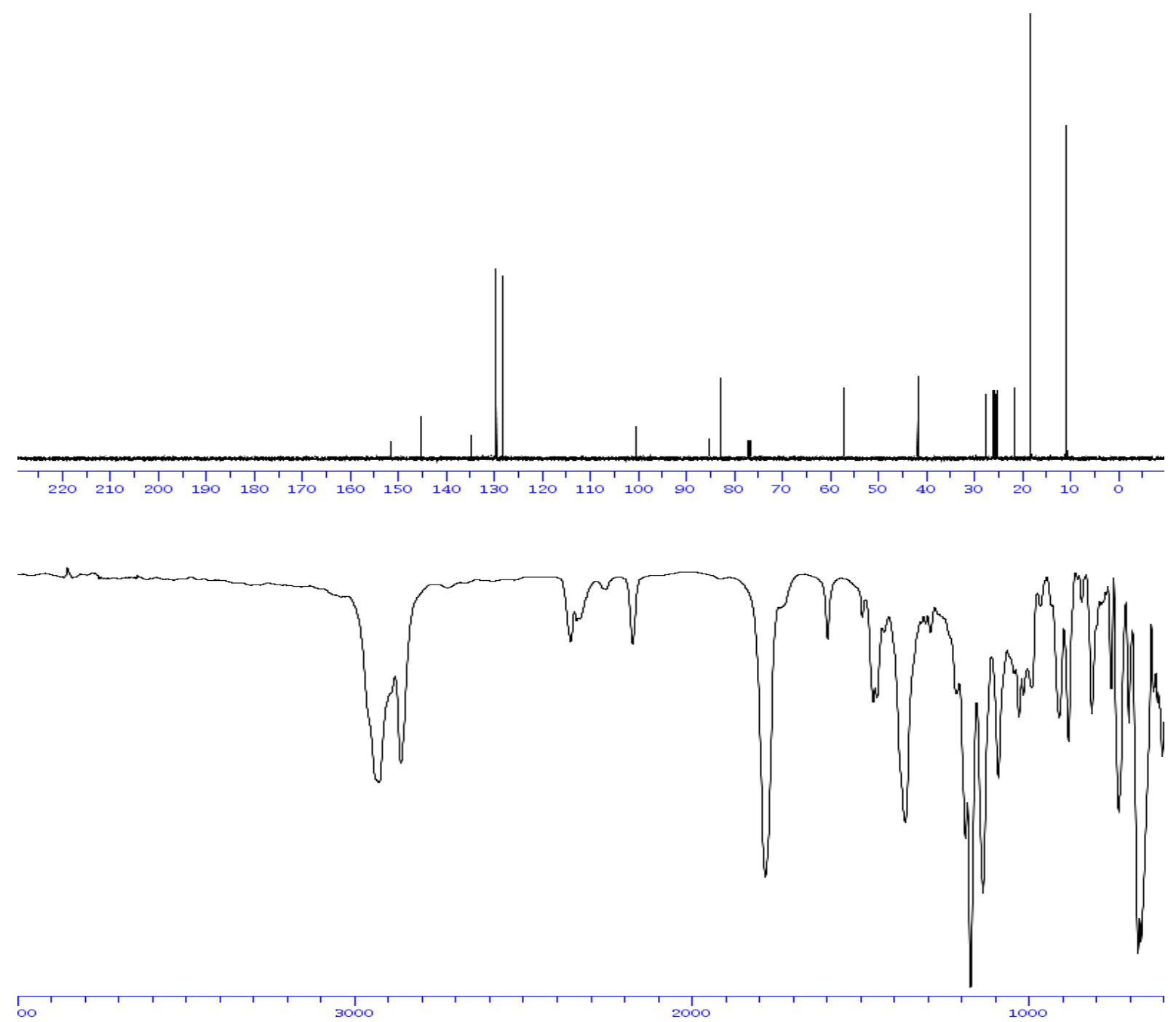


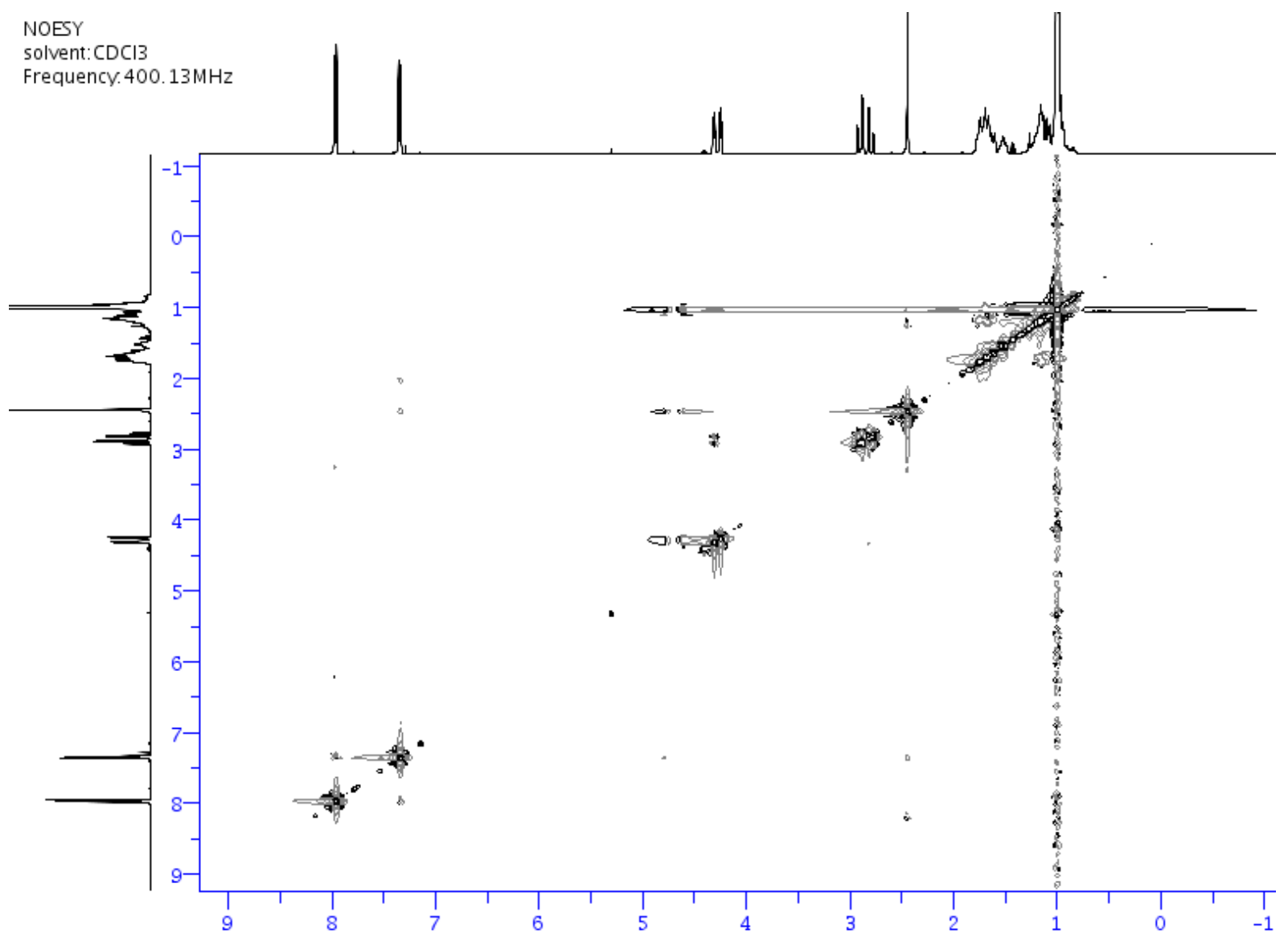


5-Cyclohexyl-3-tosyl-4-(3-(triisopropylsilyl)prop-2-ynyl)oxazolidin-2-one (7c, minor diastereoisomer)

solvent:CDCI3
Frequency. $100.61 \mathrm{MHz}$

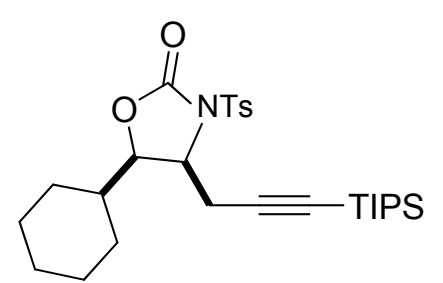

7c, Minor diastereoisomer

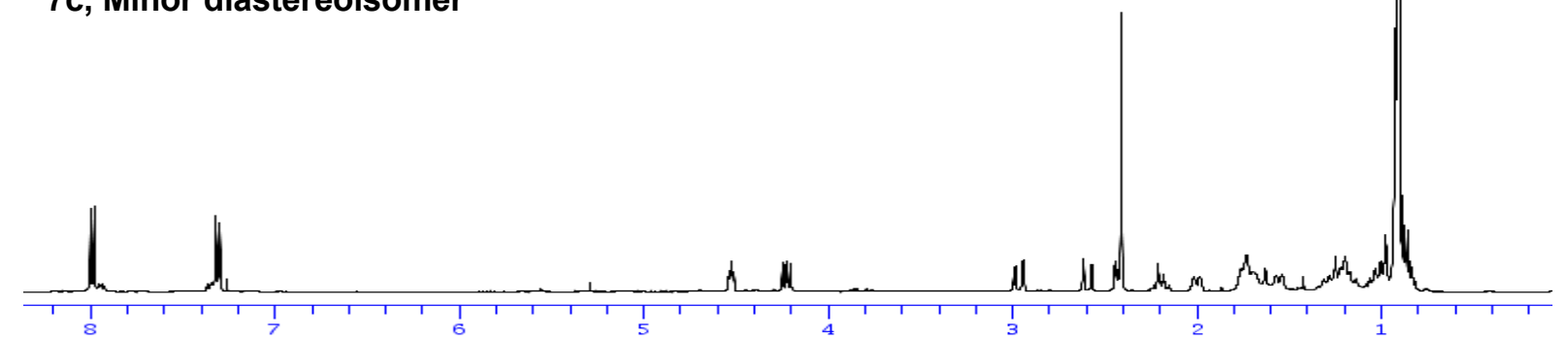

solvent: $C D C 13$

Frequency.100.61MHz
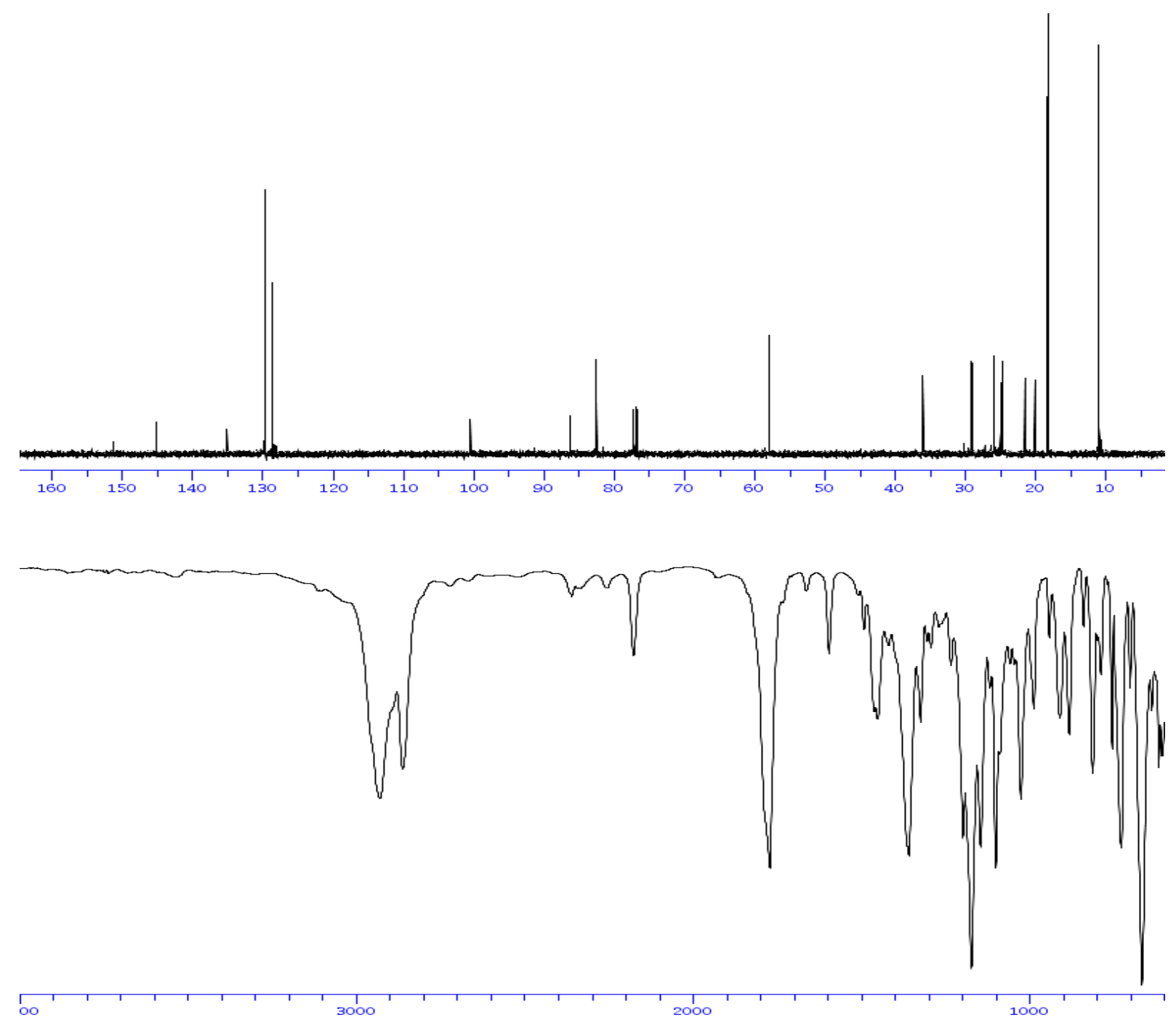
3-Tosyl-4-(3-(triisopropylsilyl)prop-2-ynyl)-1,3-oxazinan-2-one (7d)

solvent: $\mathrm{CDCl} 3$
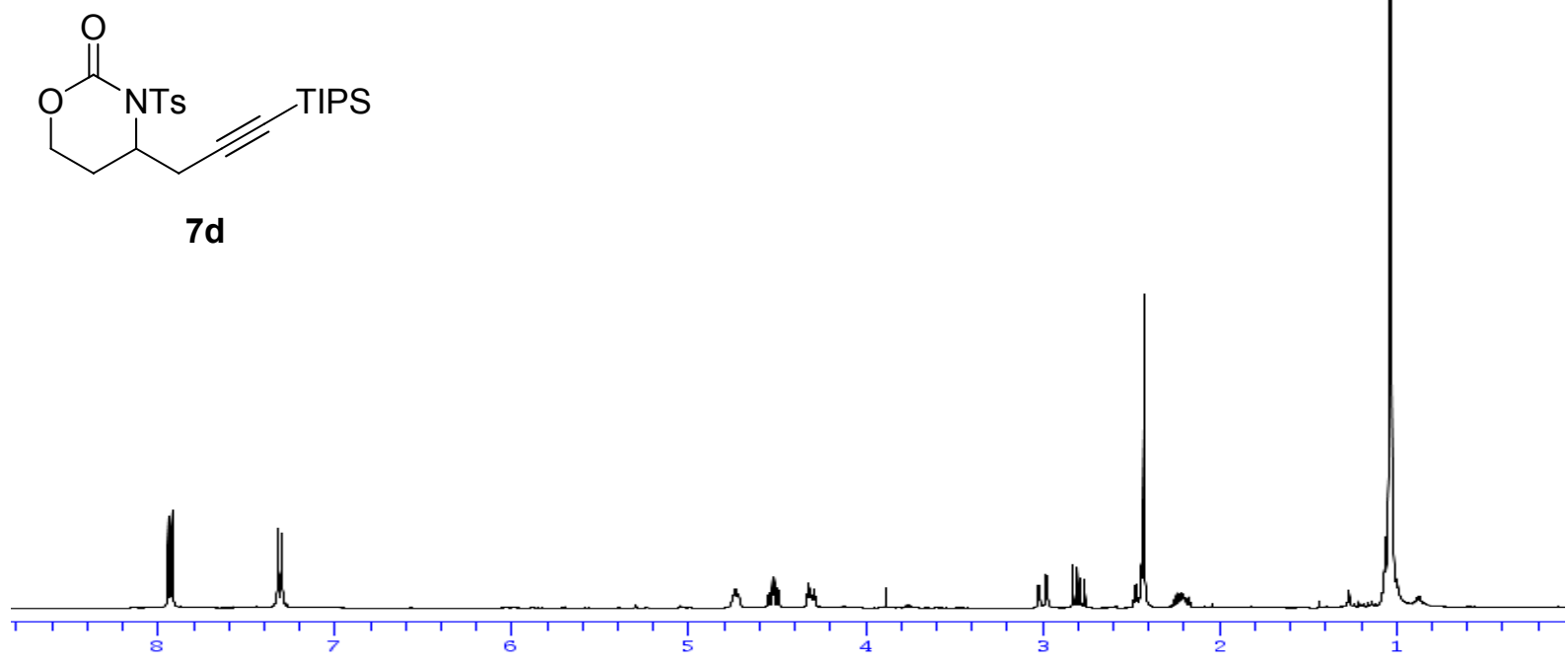

solvent: $\mathrm{CDCI} 3$

Frequency $100.61 \mathrm{MHz}$
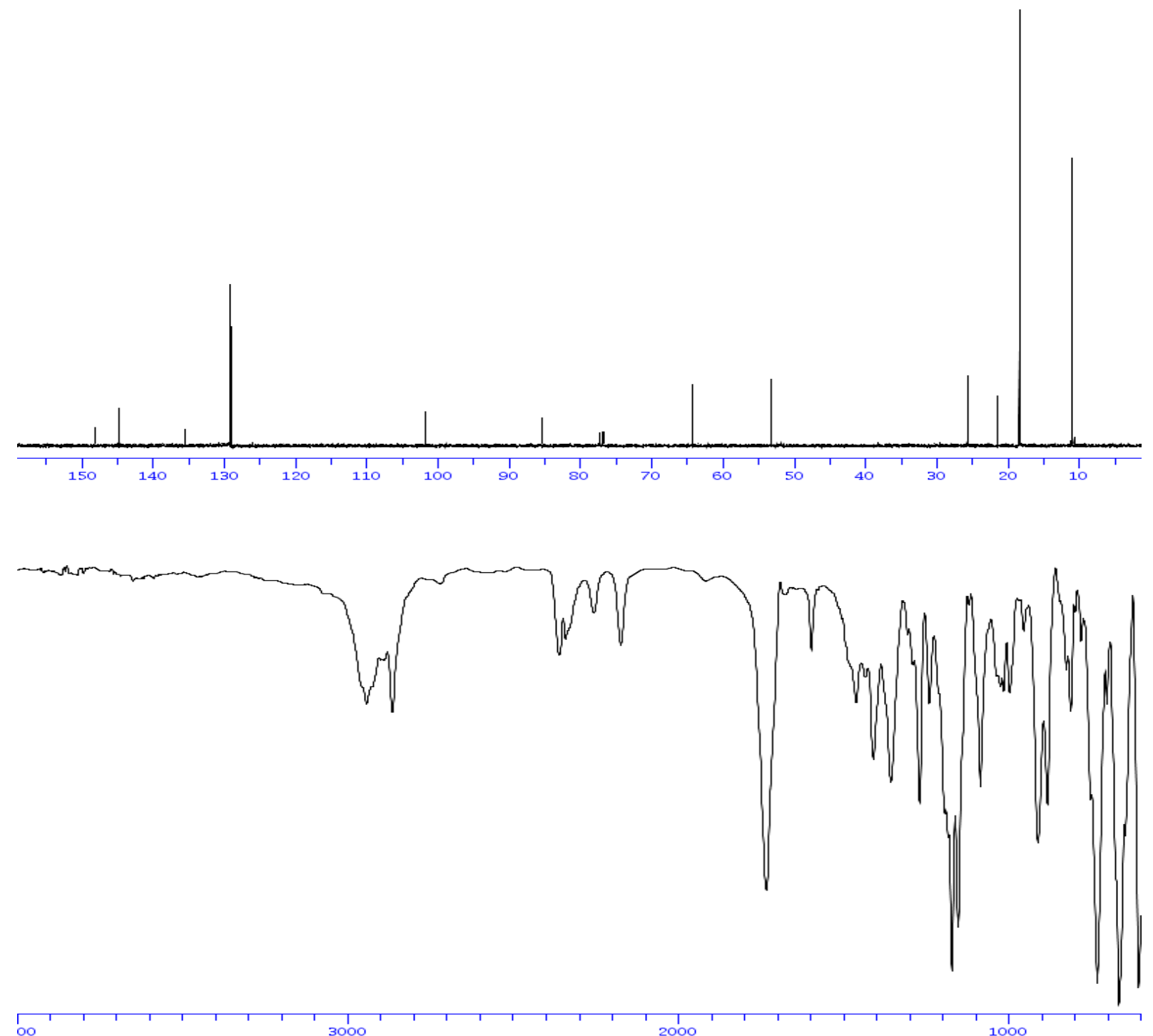
1-Tosyl-5-(3-(triisopropylsilyl)prop-2-ynyl)imidazolidin-2-one (7e)<smiles>O=C1NCC(CC#C[In])[NH2+]1</smiles>

$7 e$

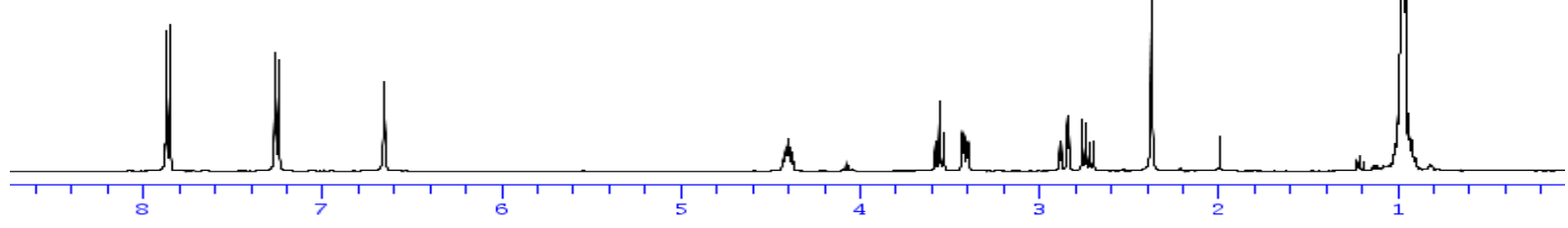

solvent: $\mathrm{CDCl}$
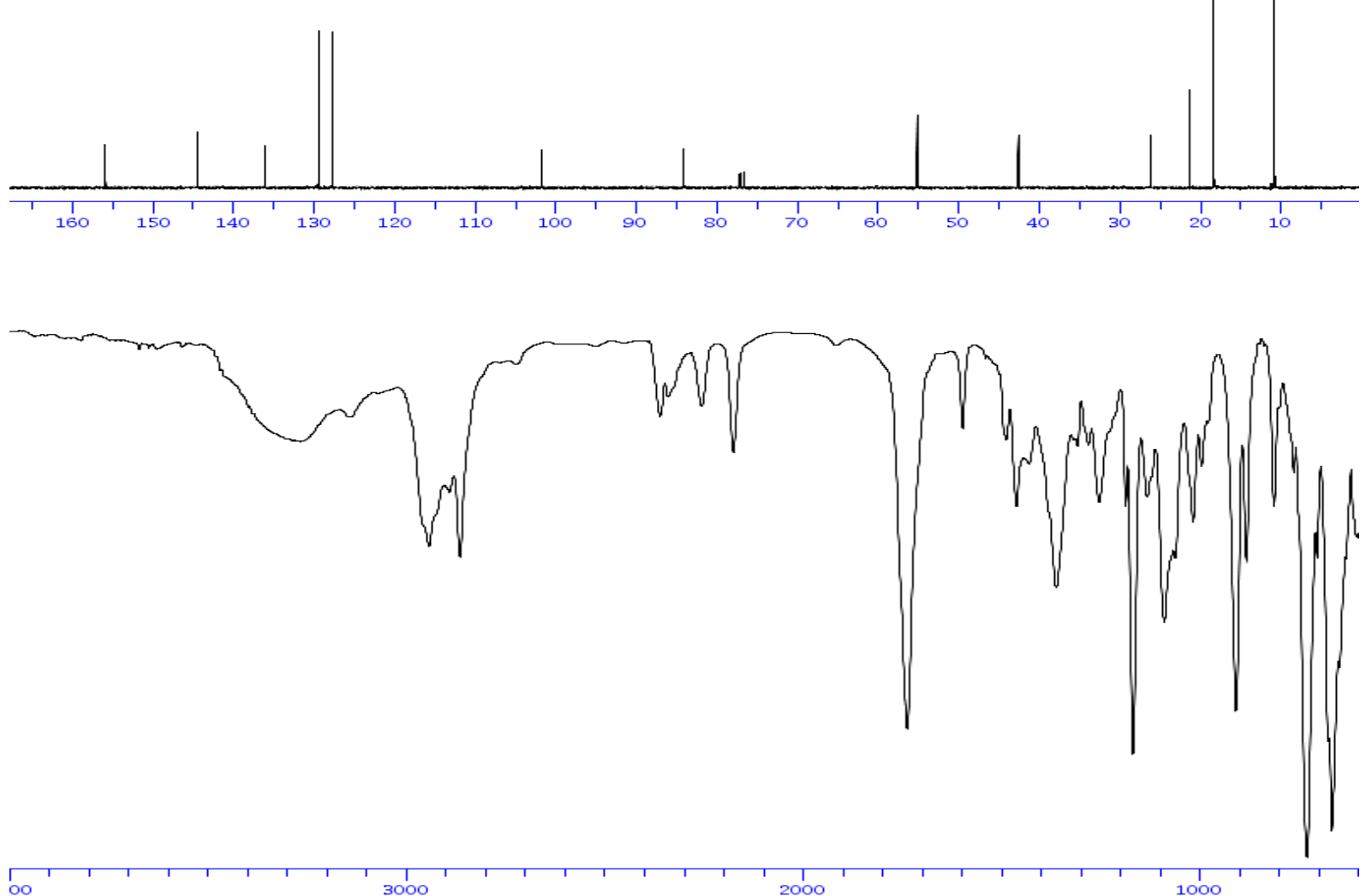
1-Allyl-3-tosyl-4-(3-(triisopropylsilyl)prop-2-ynyl)imidazolidin-2-one (7f)

solvent: $\mathrm{CDCI} 3$

equency. $400.13 \mathrm{MHz}$

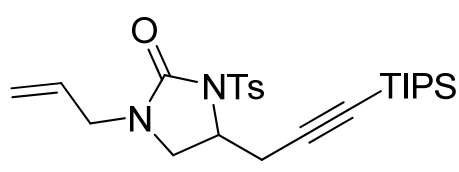

$7 f$

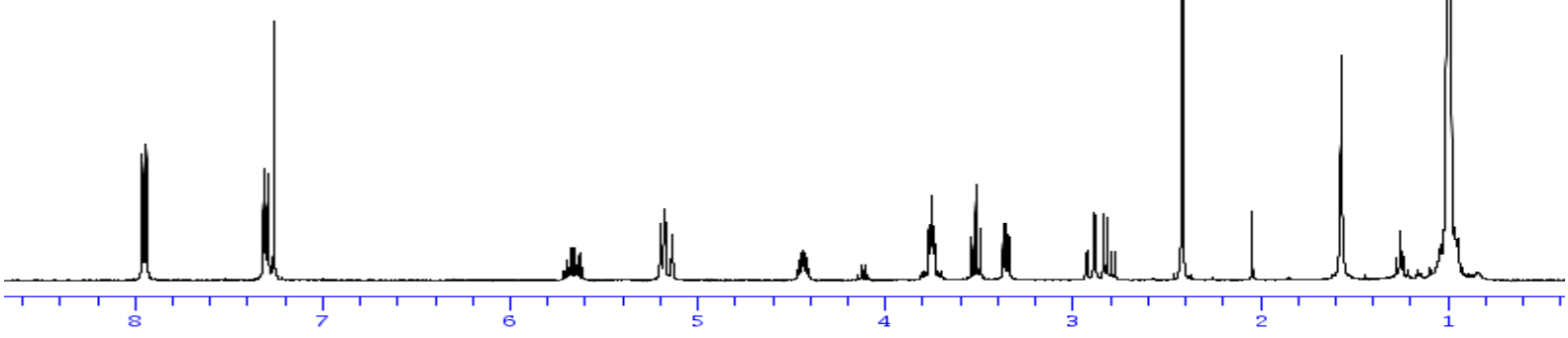

solvent: $\mathrm{CDCl} 3$

ncy. $100.61 \mathrm{MHz}$
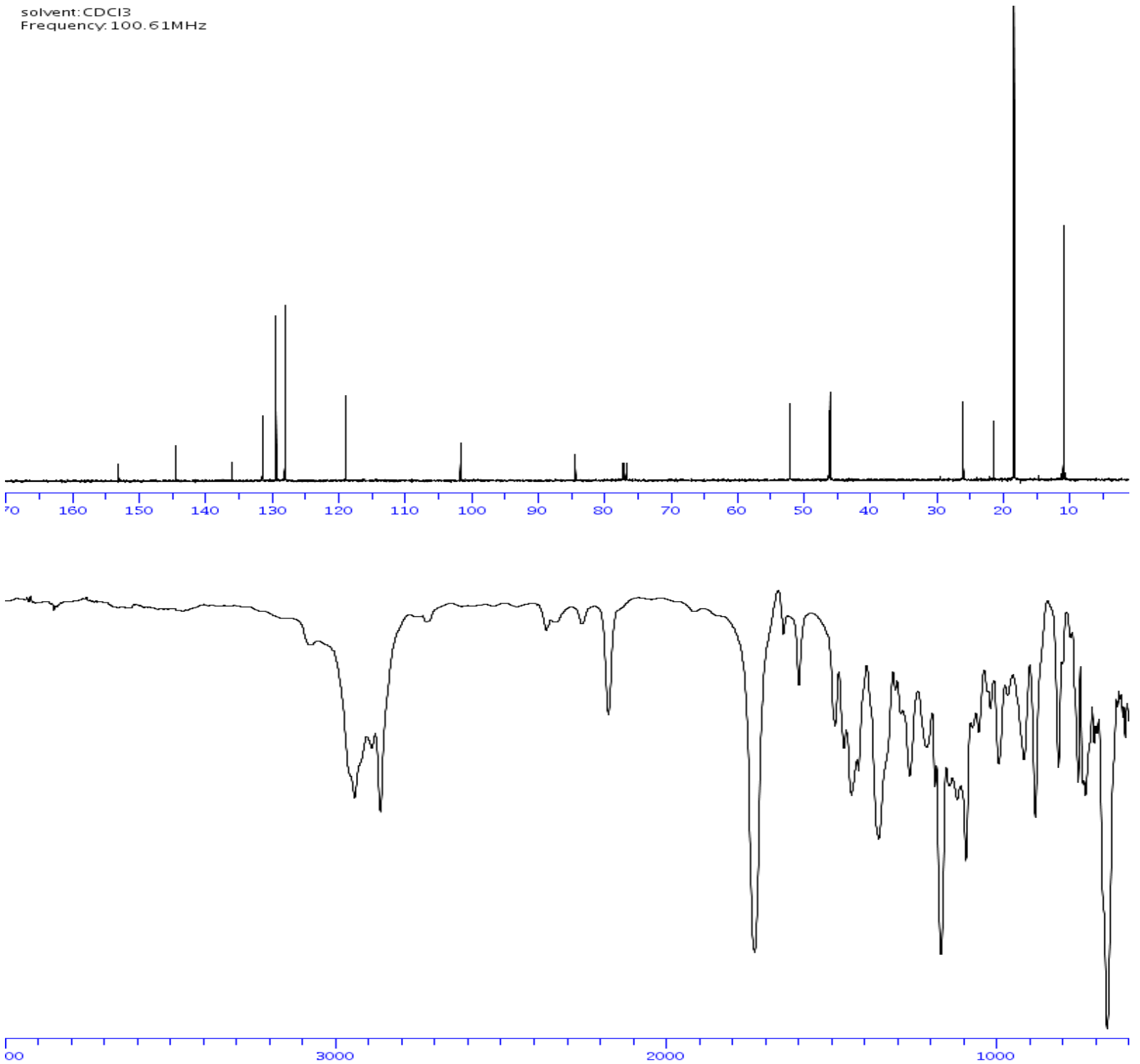
1-Benzyl-3-tosyl-4-(3-(triisopropylsilyl)prop-2-ynyl)imidazolidin-2-one (7g)

solvent: $\mathrm{CDCl} 3$

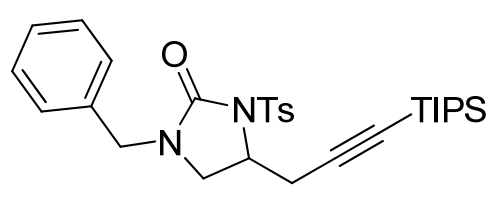

$7 g$

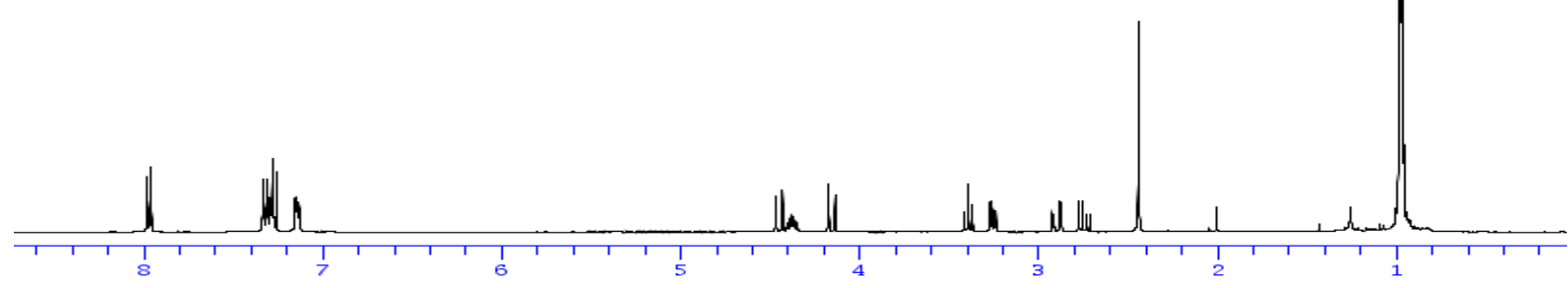

solvent: $C D C 13$
Frequency. $100.61 \mathrm{MHz}$
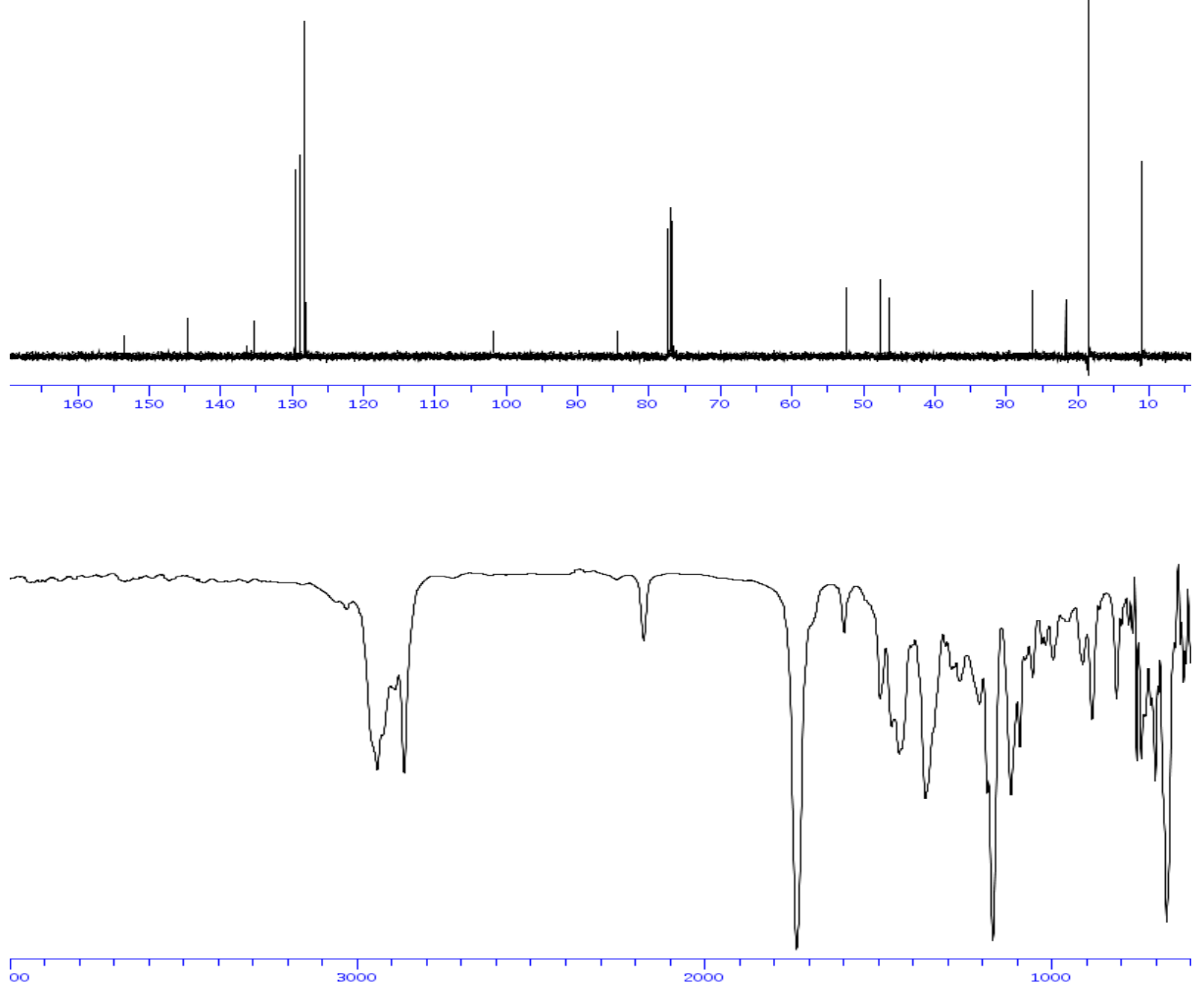
5-(Prop-2-ynyl)pyrrolidin-2-one (8a)

solvent: $\mathrm{CDCI}$

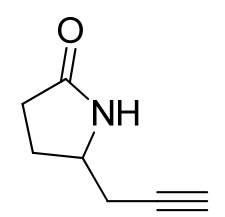

$8 a$

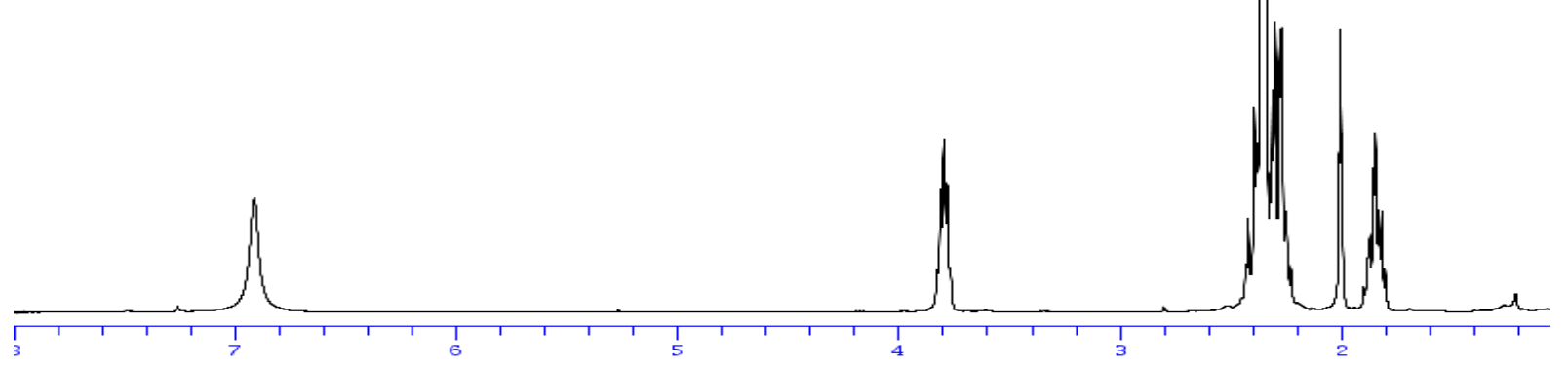

solvent: $\mathrm{CDCI}$

ency. $100.61 \mathrm{MHz}$

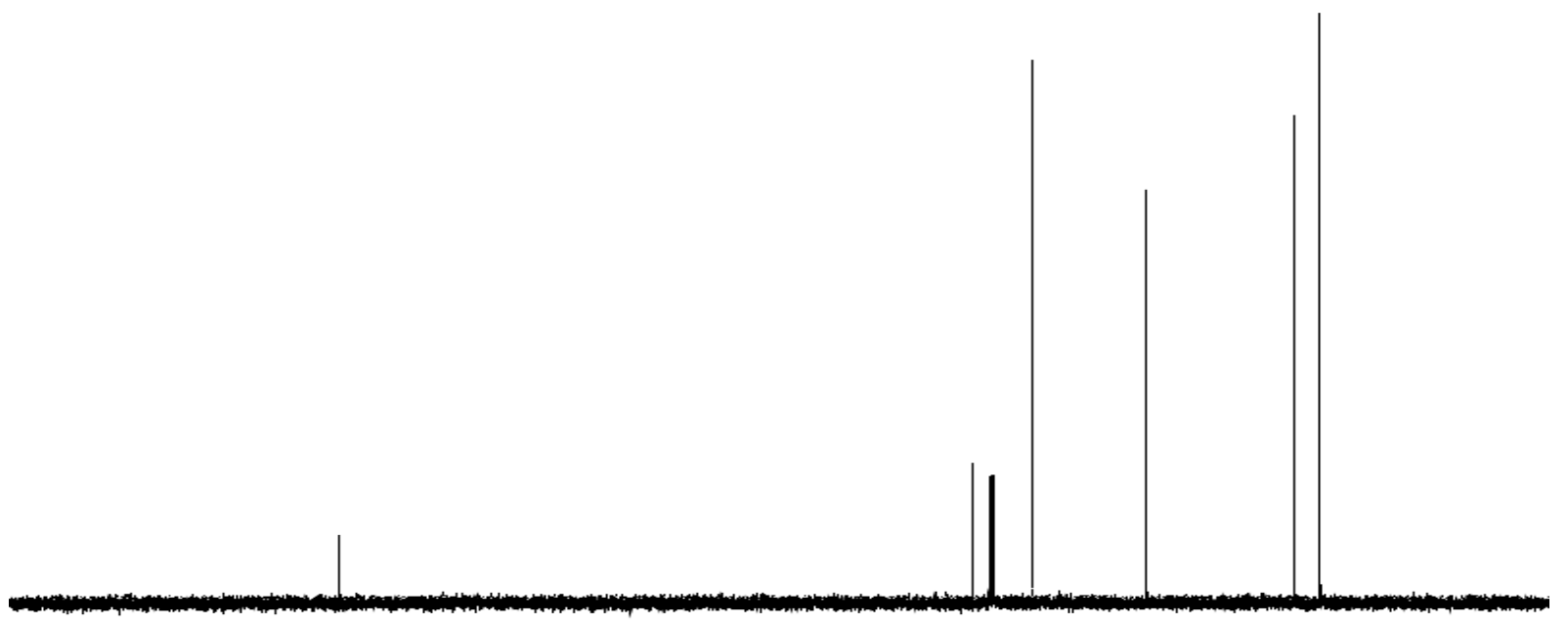


4-(Prop-2-ynyl)oxazolidin-2-one (8b)

solvent: $\mathrm{CDCI} 3$

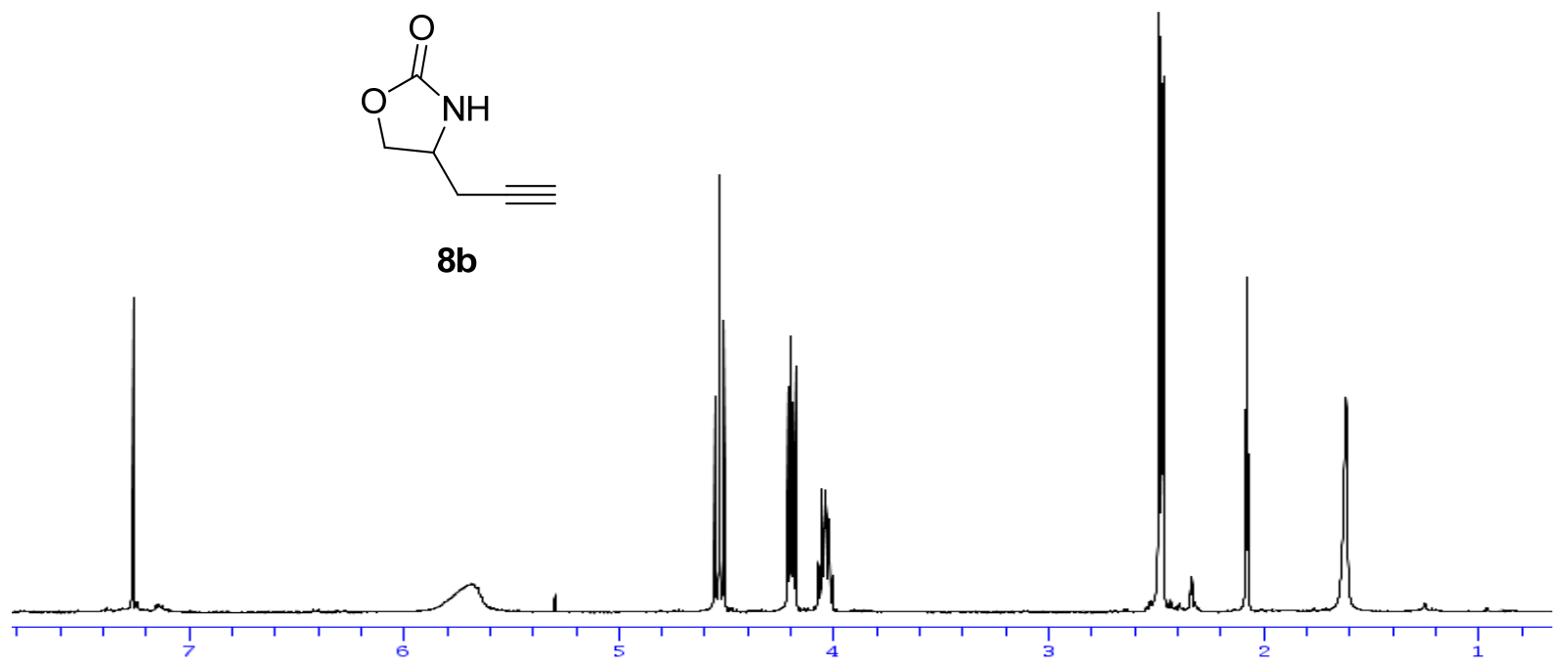

solvent: $\mathrm{CDCI}$
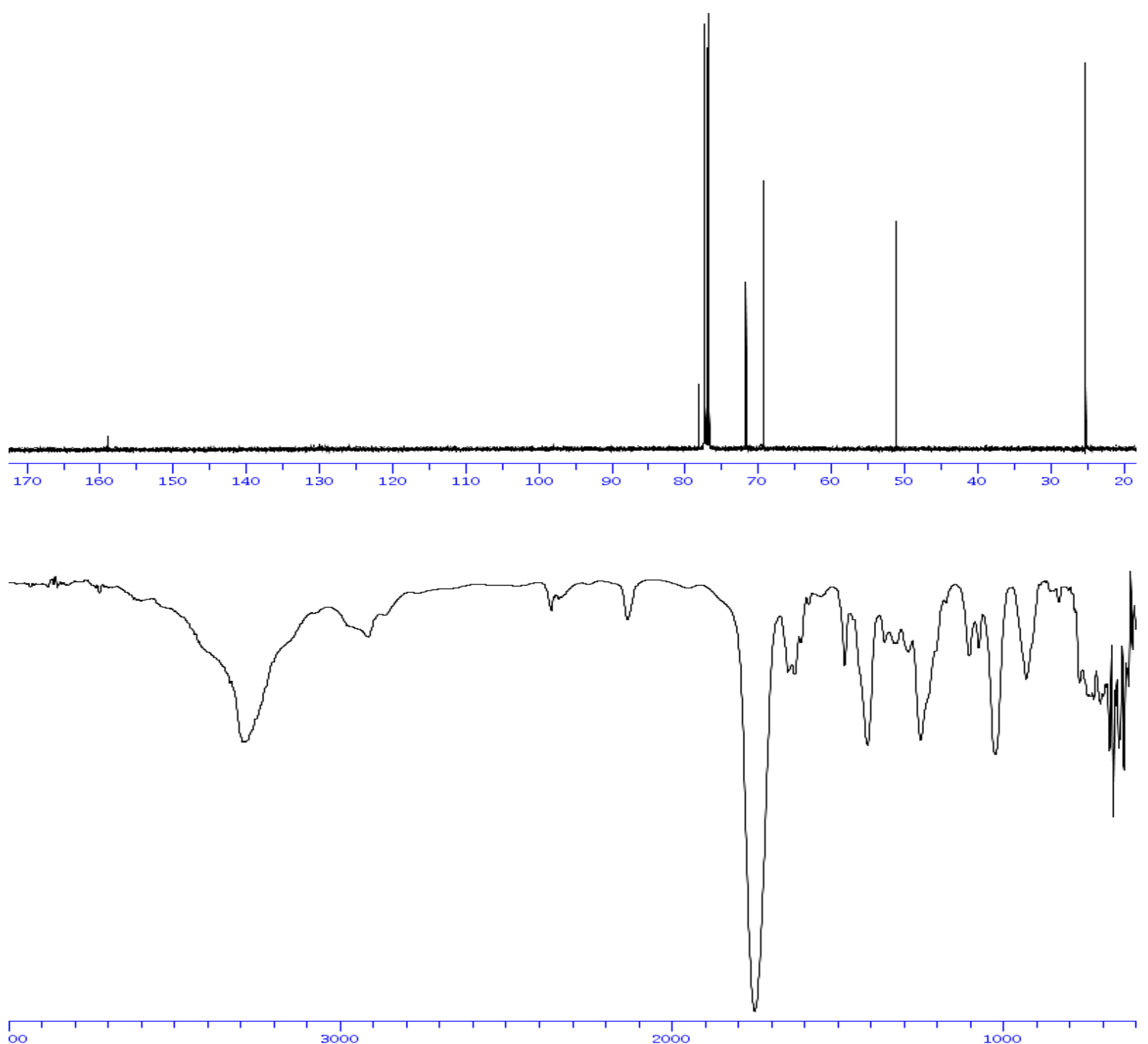
6-(Prop-2-ynyl)piperidin-2-one (8c)

solvent: $\mathrm{CD} 2 \mathrm{Cl} 2$<smiles>C#CCC1CCCC(=O)N1</smiles>

$8 c$

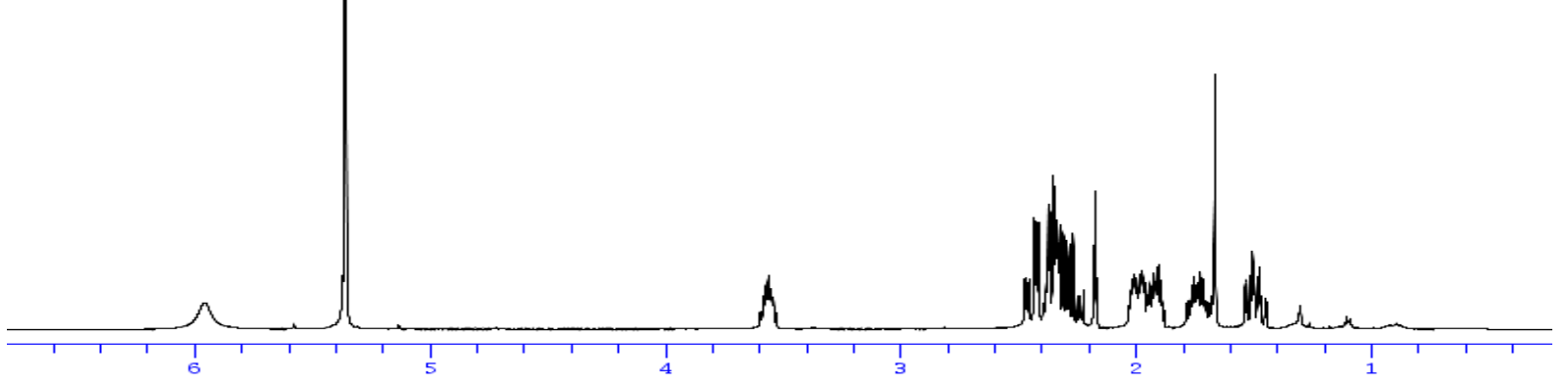

solvent: $\mathrm{CD} 2 \mathrm{Cl} 2$

$0.61 \mathrm{MHz}$
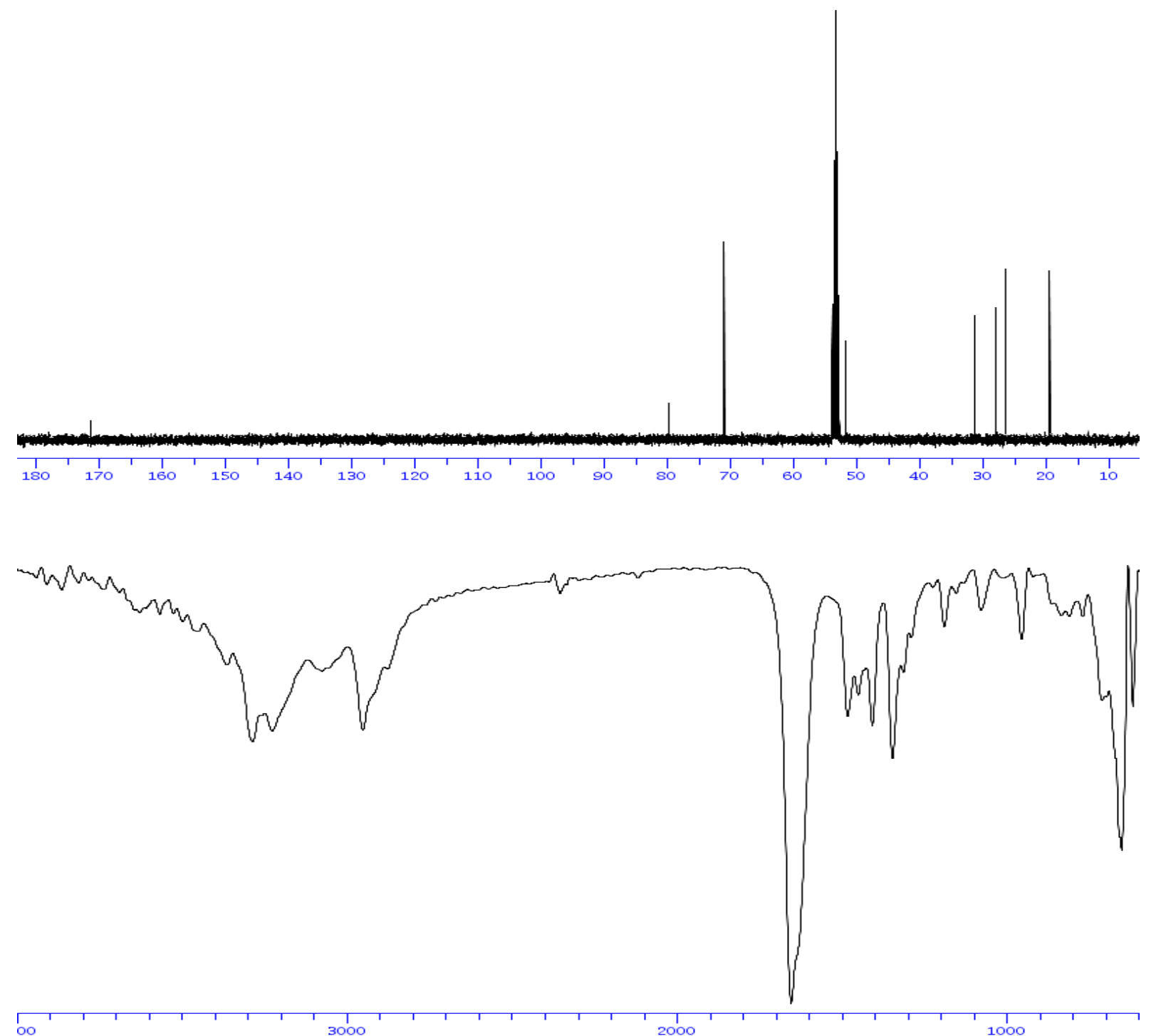
3-(benzyloxymethyl)- $N$-tosylpent-4-enamide (11)

Solvent: $\mathrm{CDCl} 3$
Frequency. $400.13 \mathrm{MHz}$

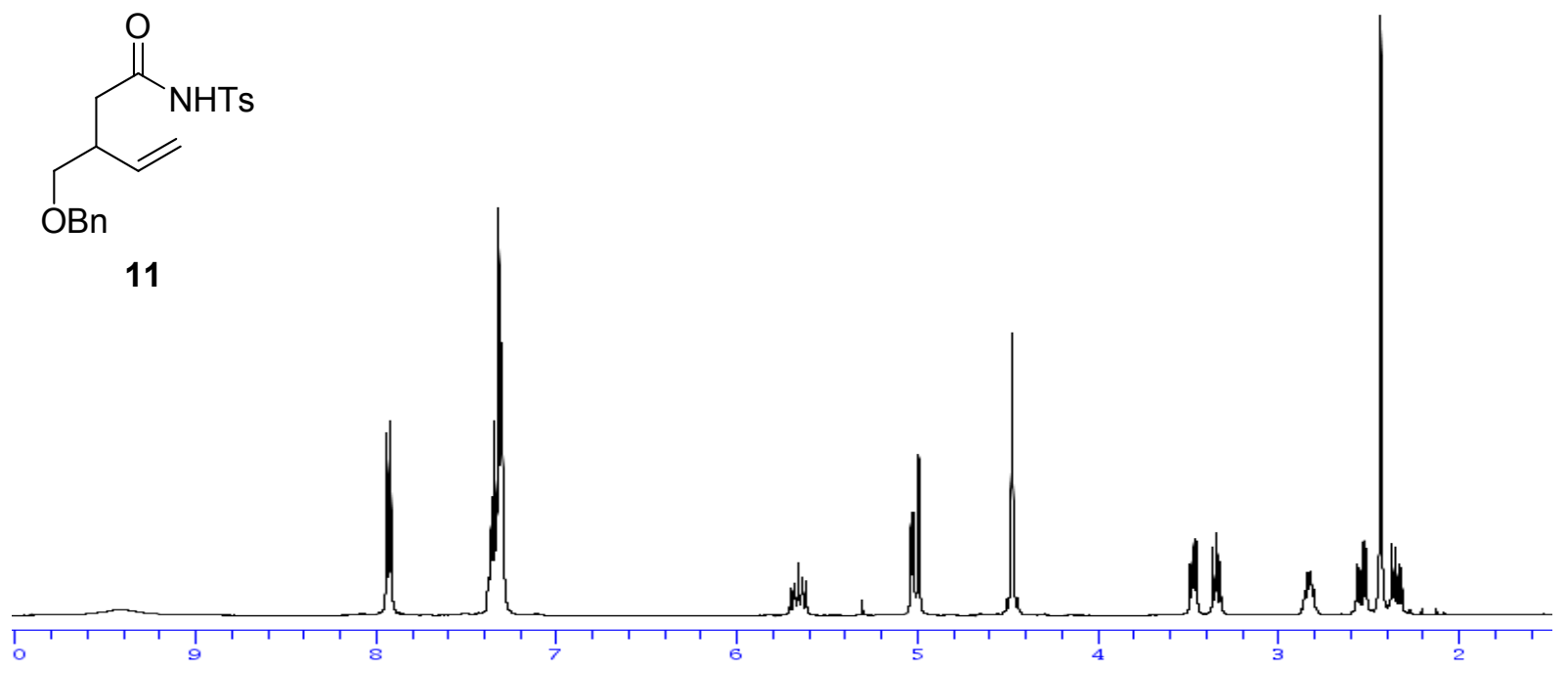

solvent: $\mathrm{CDCl} 3$

quency. $100.61 \mathrm{MHz}$
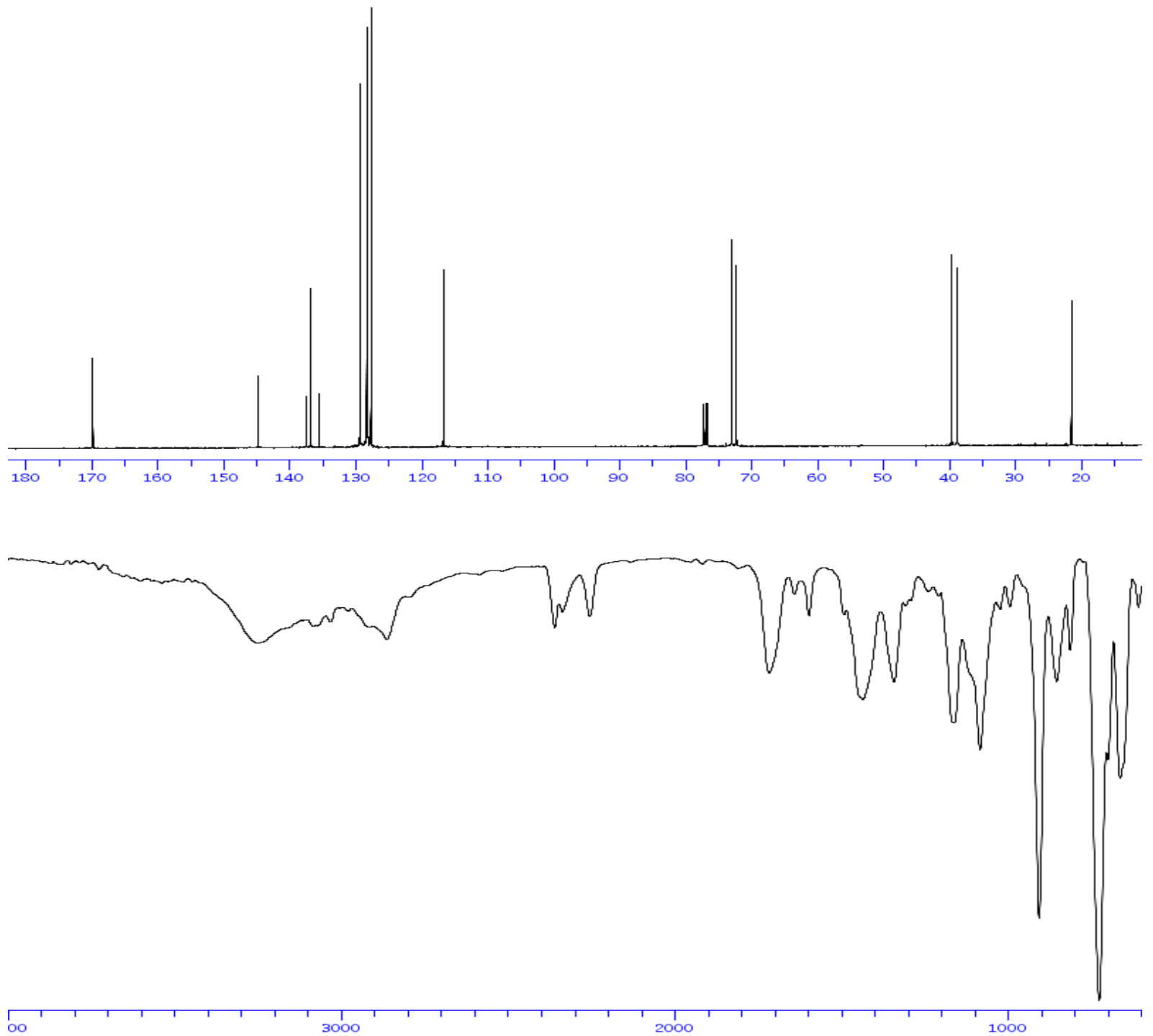
4-(Benzyloxymethyl)-1-tosyl-5-(3-(triisopropylsilyl)prop-2-ynyl)pyrrolidin-2-one (12)

solvent: $\mathrm{CDCl} 3$
Frequency. $400.13 \mathrm{MHz}$

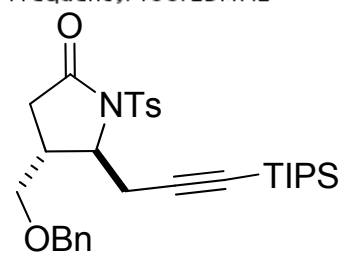

12

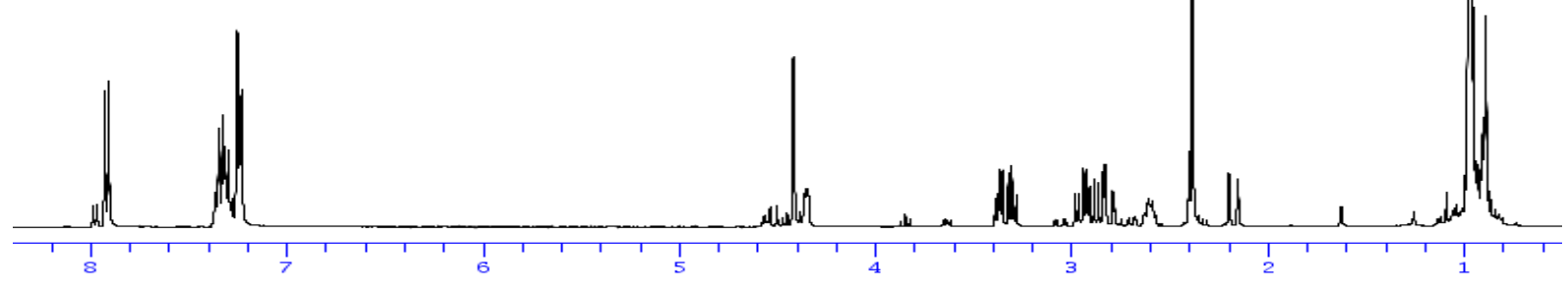

solvent: $\mathrm{CDCI} 3$

Frequency 100. $61 \mathrm{MHz}$
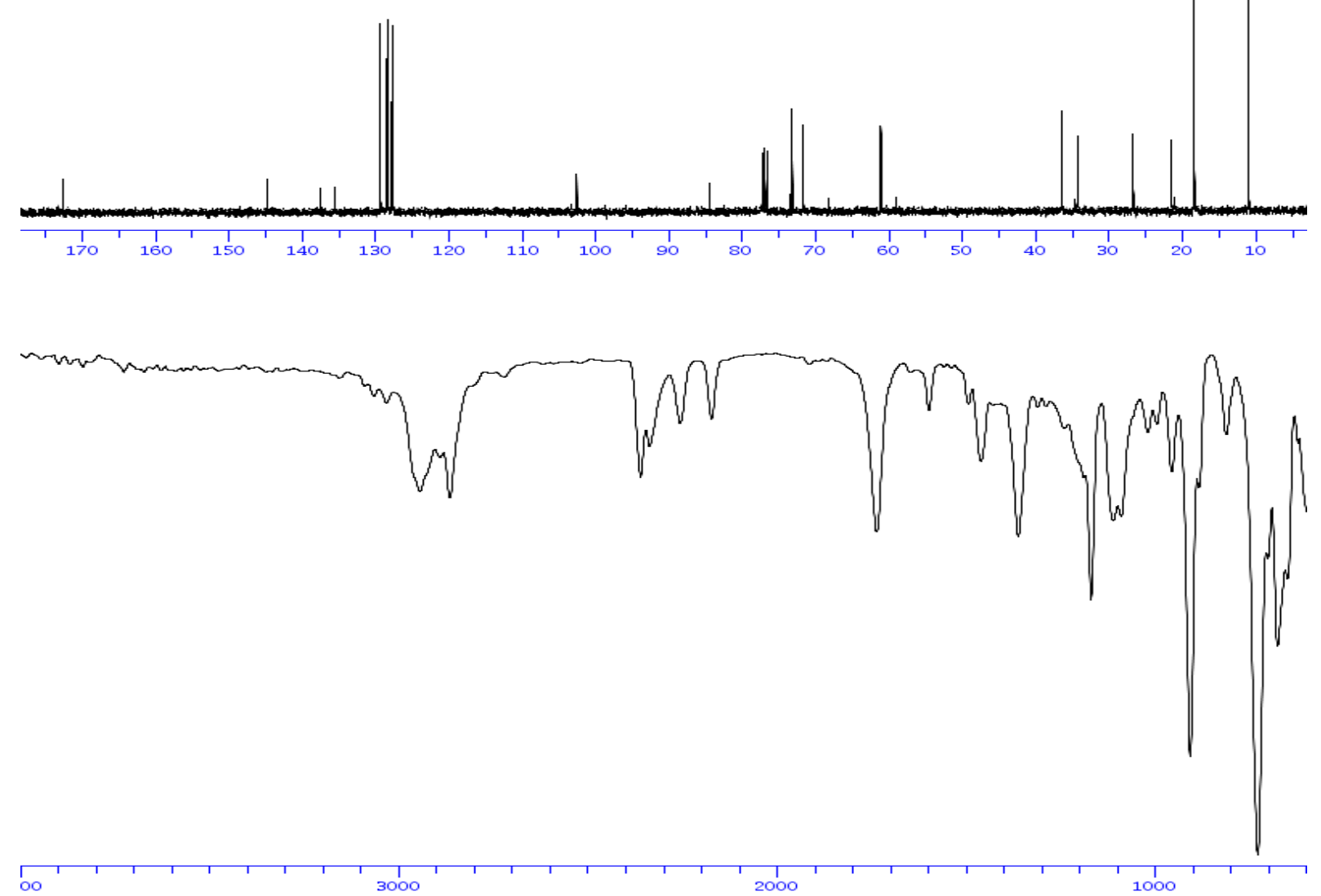
4-(benzyloxymethyl)-5-(prop-2-ynyl)pyrrolidin-2-one (13)

solvent: $\mathrm{CDCl} 3$<smiles>C#CCC1NC(=O)CC1COCc1ccccc1</smiles>

13

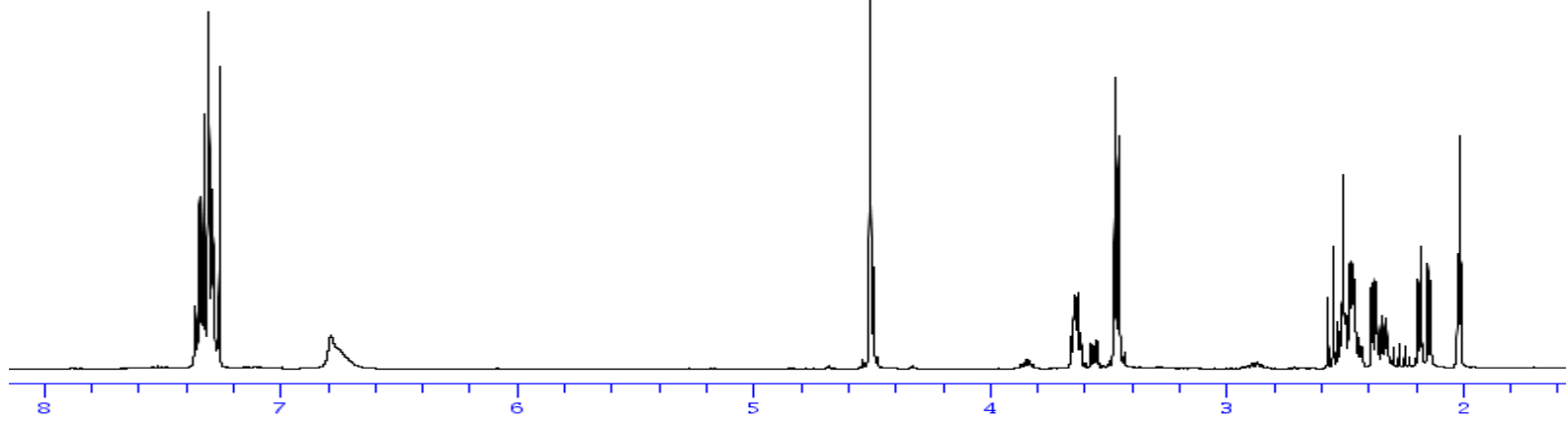

Solvent: $\mathrm{CDCl} 3$
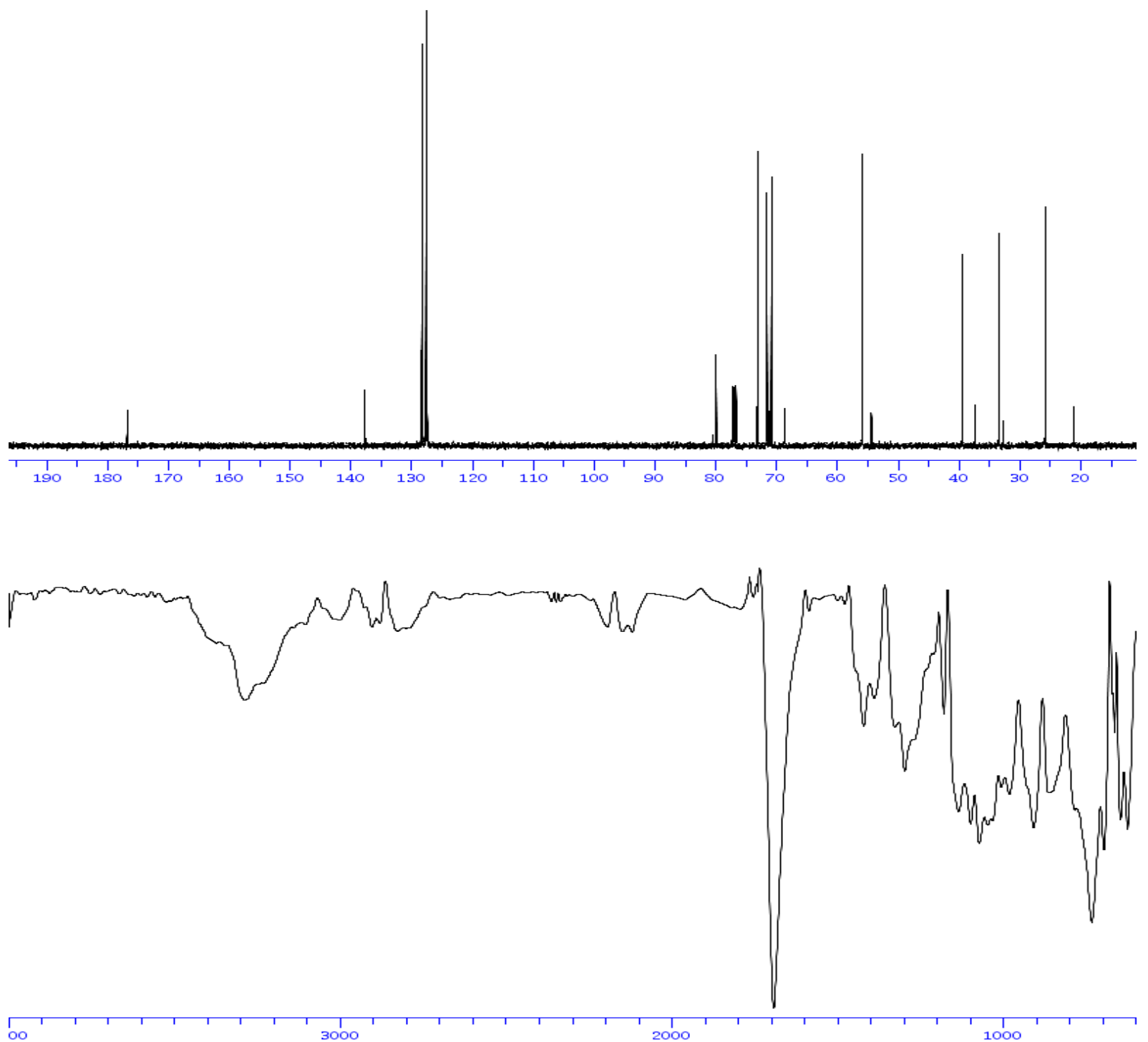
7,7a-Dihydro-1 $H$-pyrrolizin-3(2H)-one (9a).

solvent: $\mathrm{CD} 2 \mathrm{Cl} 2$
Frequency. $400.13 \mathrm{MH}$

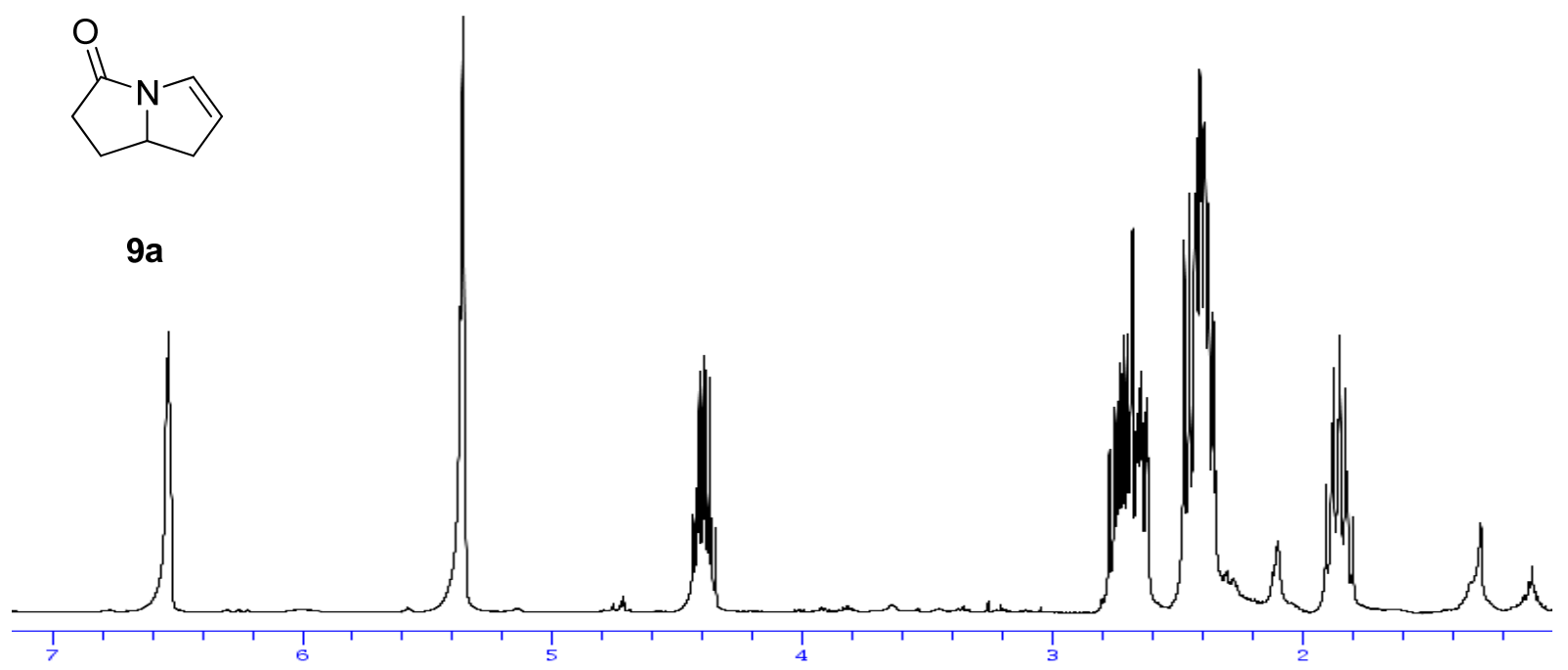

solvent: $\mathrm{CD} 2 \mathrm{Cl} 2$

$.61 \mathrm{MHz}$
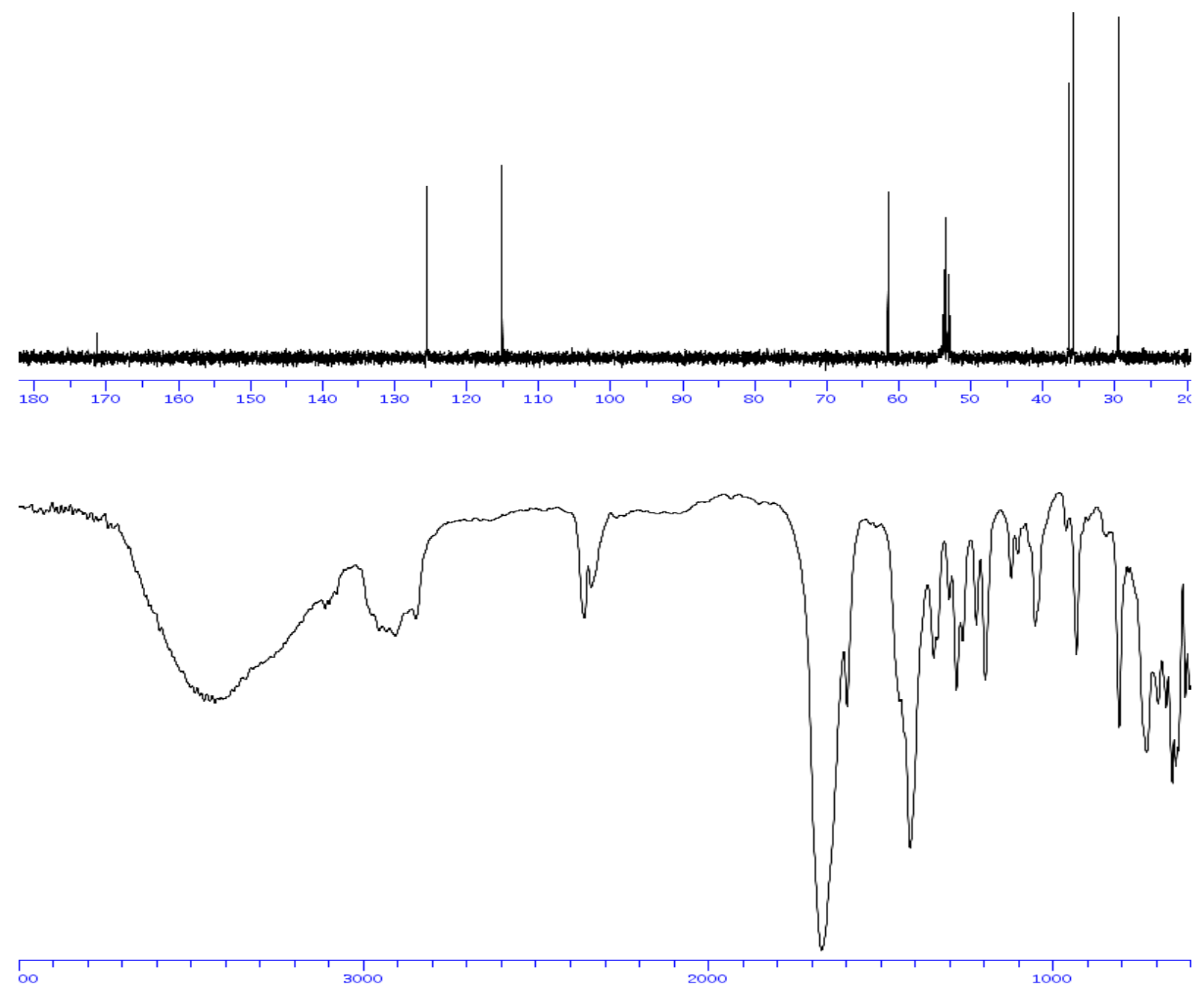
7,7a-Dihydropyrrolo[1,2-c]oxazol-3(1H)-one (9b)

solvent: $C D C I 3$
FrequencY.4O0. $13 \mathrm{MHz}$

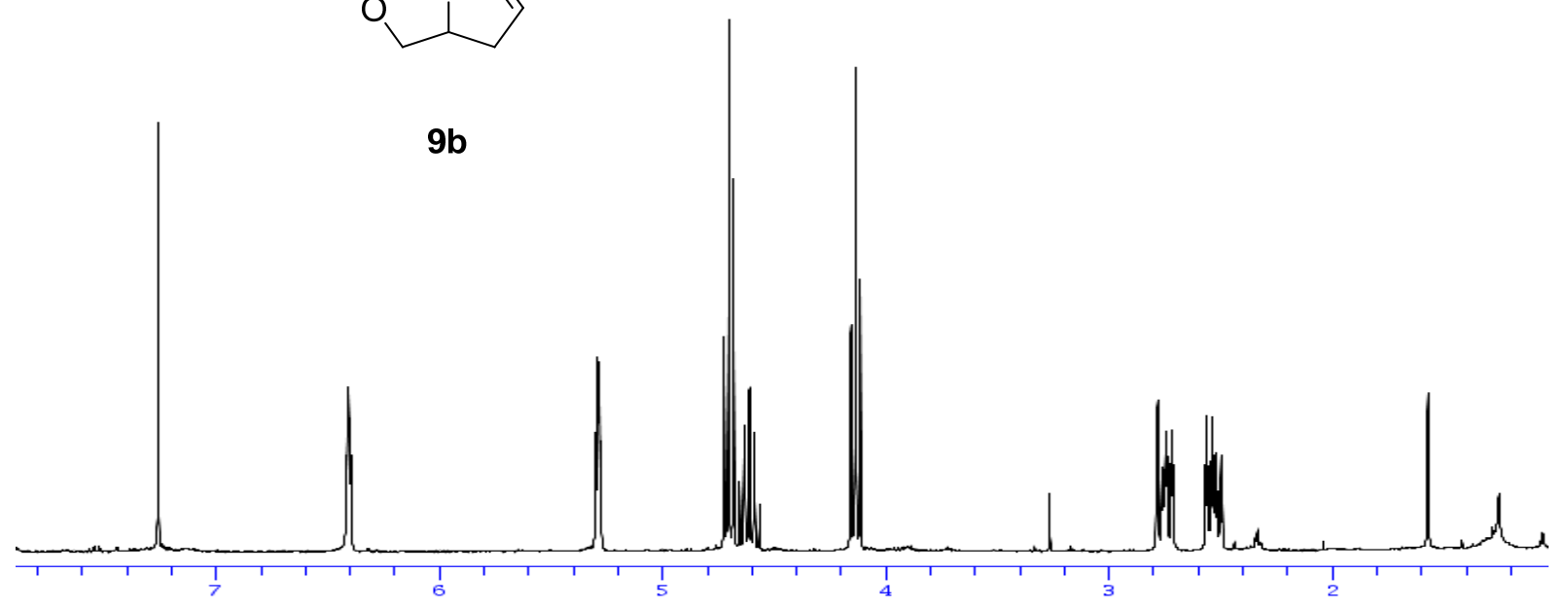

solvent: $\mathrm{CDCI}$
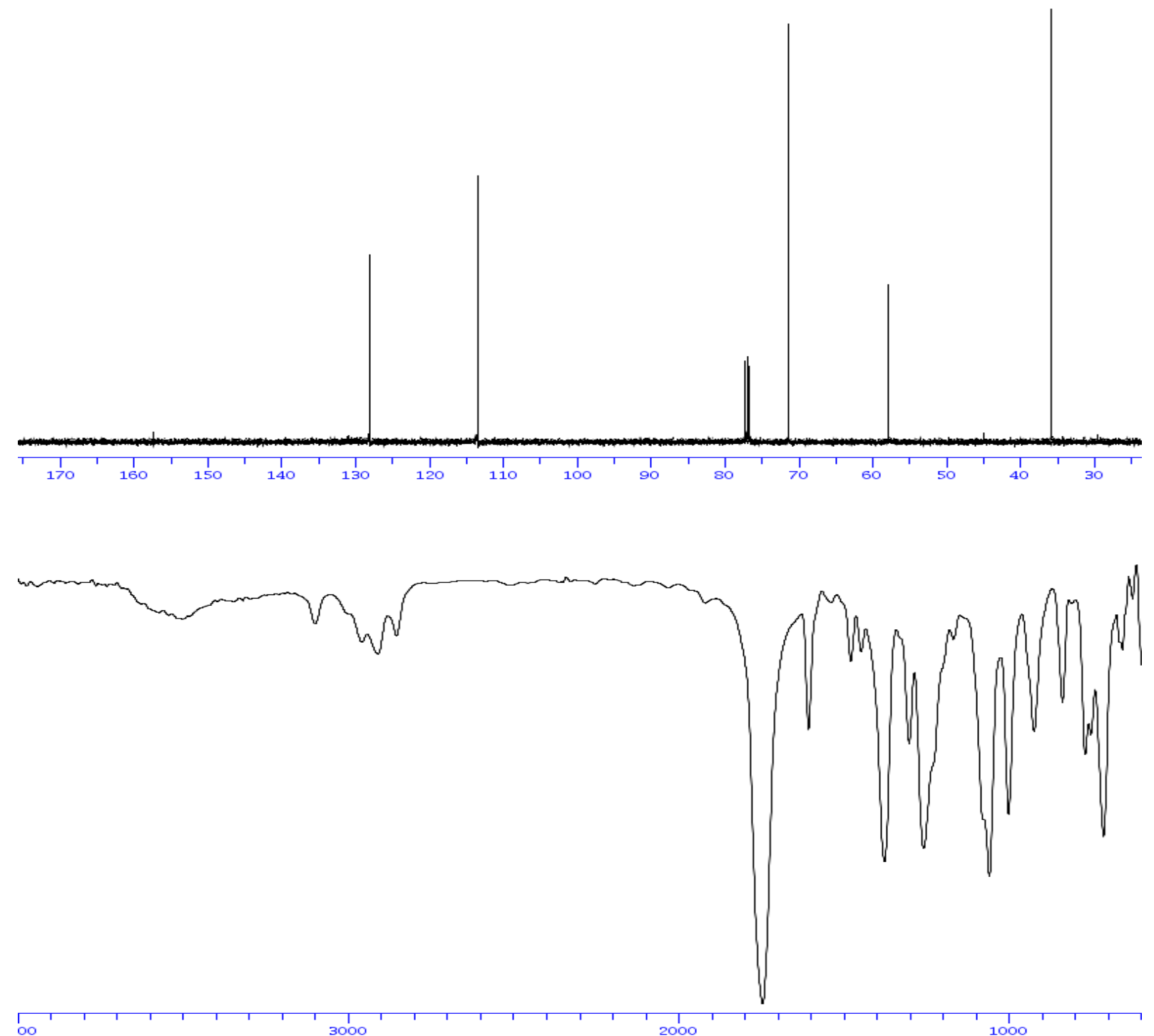
6,7,8,8a-tetrahydroindolizin-5(1H)-one (9c)

solvent: $\mathrm{CDCl}$

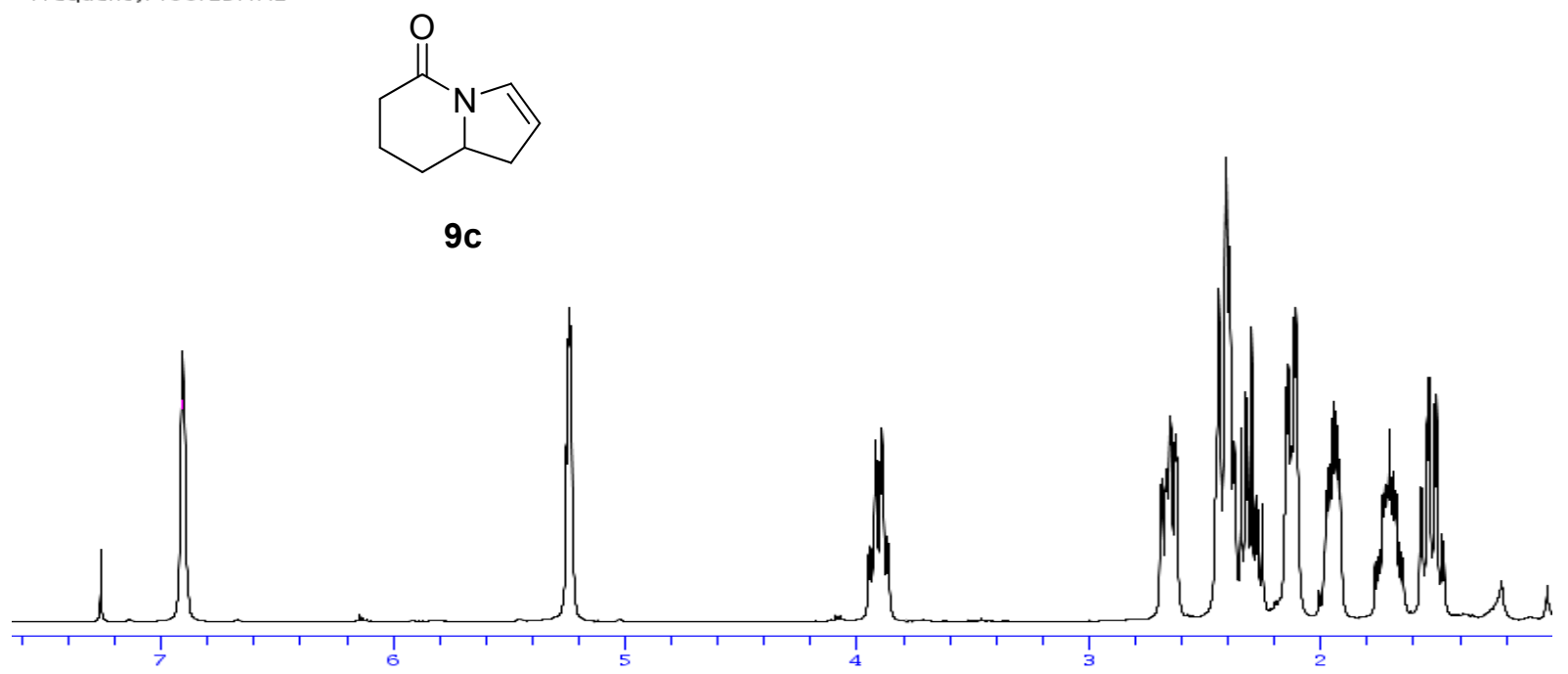

solvent: $\mathrm{CDCl} 3$
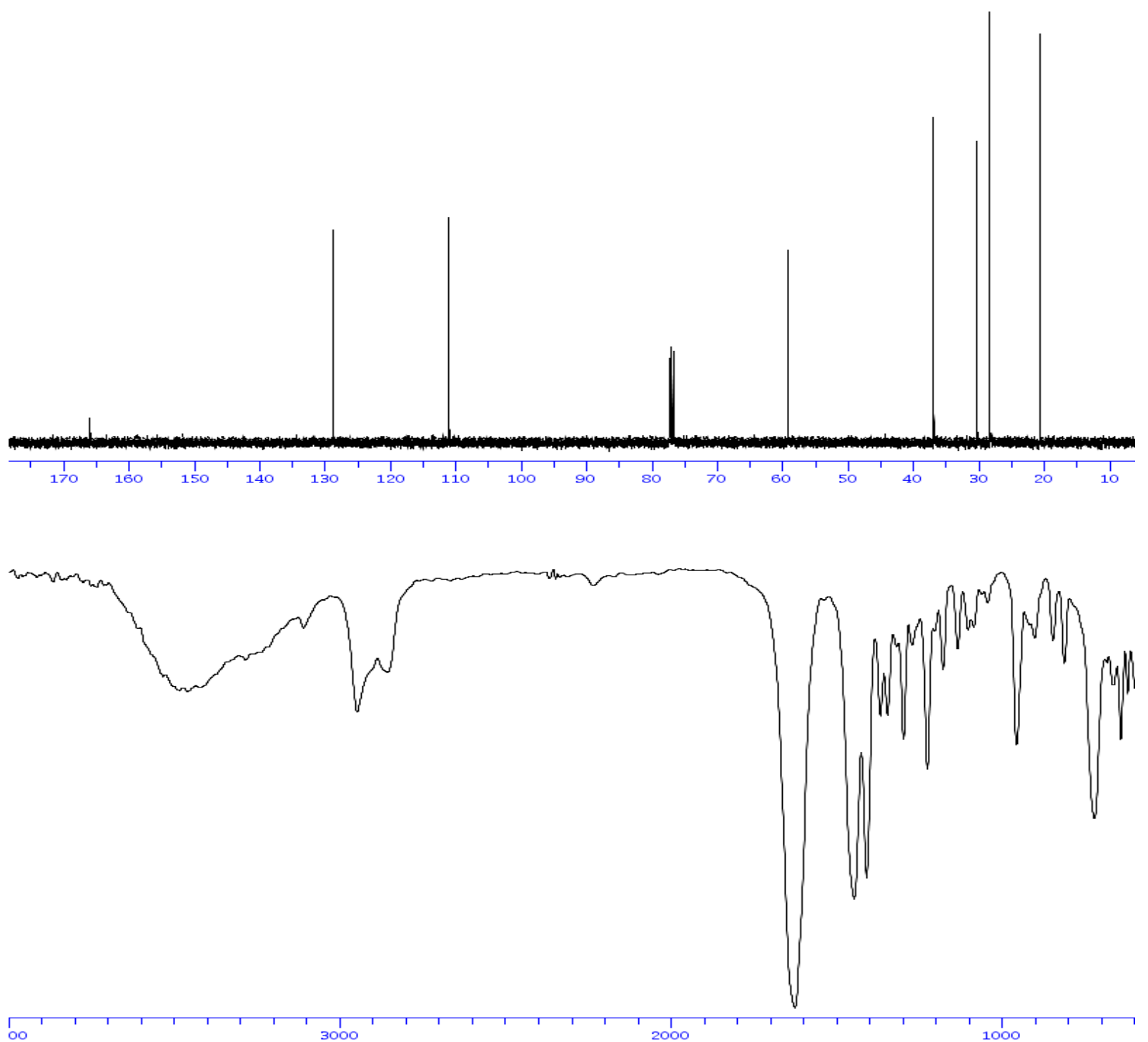
1-(Benzyloxymethyl)-7,7a-dihydro-1H-pyrrolizin-3(2H)-one (14).
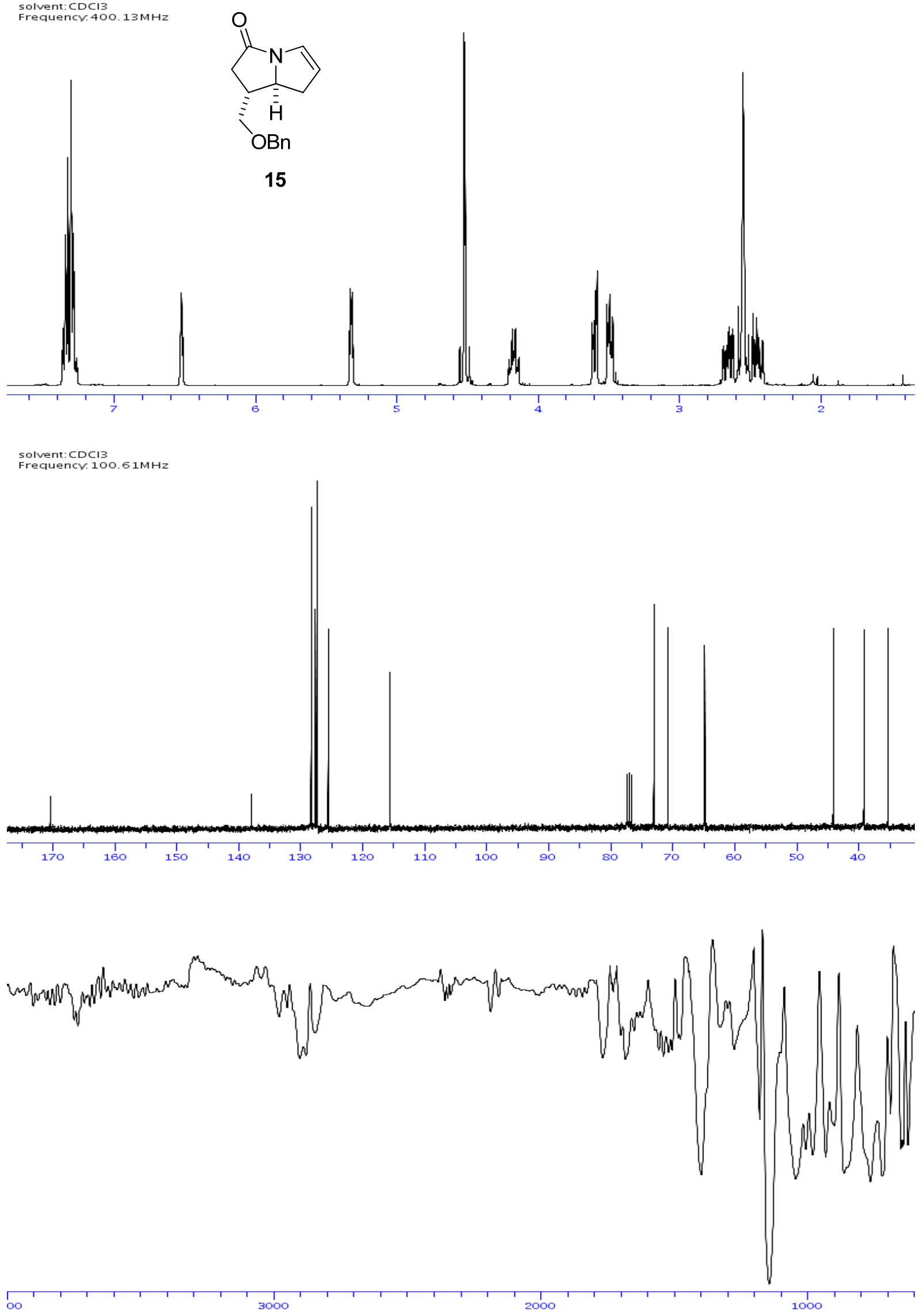
((1S,7aR)-hexahydro-1H-pyrrolizin-1-yl)methanol (16) (( \pm )-Trachelanthamidine)

solvent: $\mathrm{CDCI} 3$

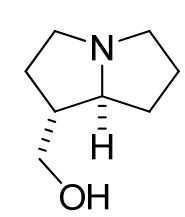

16

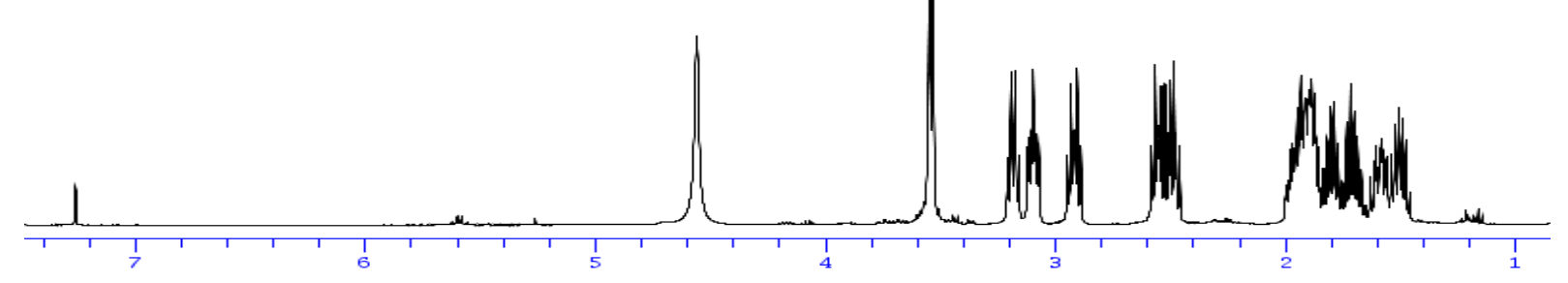

solvent: $\mathrm{CDCl}$
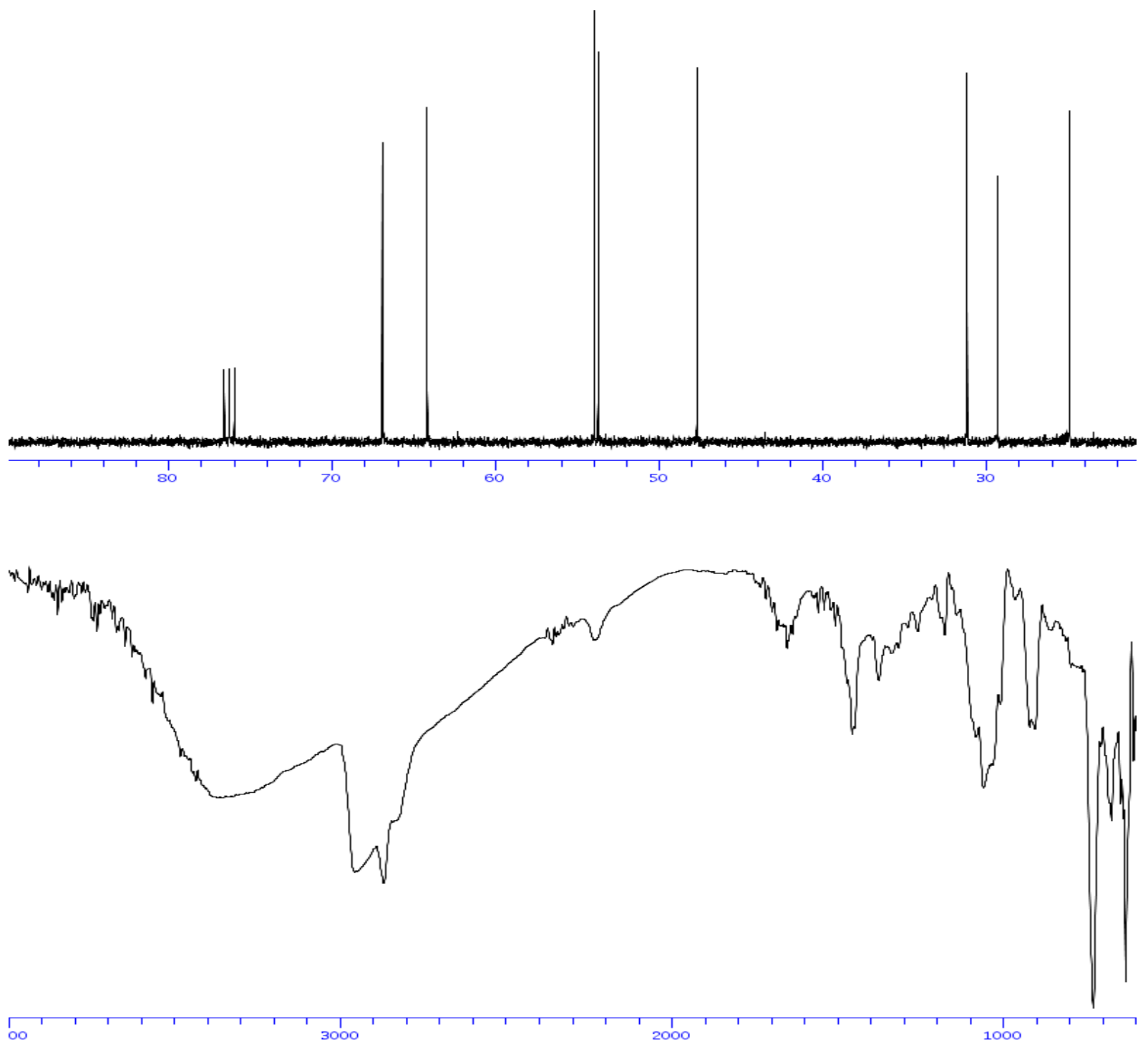